\title{
A SUBSIDIARIEDADE COMO VETOR OBJETIVO DE RESTRIÇÃO À INTERVENÇÃO REGULATÓRIA DO ESTADO NA ECONOMIA: DEFINIÇÃO E INSTRUMENTALIZAÇÃO
}

Dissertação de Mestrado

Orientador: Professor Associado Floriano de Azevedo Marques Neto

FACULDADE DE DIREITO DA UNIVERSIDADE DE SÃO PAULO SÃO PAULO 


\section{A SUBSIDIARIEDADE COMO VETOR OBJETIVO DE RESTRIÇÃO À INTERVENÇÃO REGULATÓRIA DO ESTADO NA ECONOMIA: DEFINIÇÃO E INSTRUMENTALIZAÇÃO}

Dissertação apresentada à Faculdade de Direito da Universidade de São Paulo como requisito parcial para a obtenção do título de Mestre em Direito do Estado, na subárea Direito Administrativo, sob a orientação do Professor Associado Floriano de Azevedo Marques Neto. 
BANCA EXAMINADORA 


\section{AGRADECIMENTOS}

Como sabem os que já tiveram essa experiência, a elaboração de uma dissertação ou tese acadêmica é um processo longo, desgastante, mas compensador. Justamente por isso demanda a ajuda, compreensão e paciência de muitos. E no presente caso não haveria porque ser diferente.

De início, agradeço ao Professor Floriano de Azevedo Marques Neto pela oportunidade de ingressar na pós-graduação da Faculdade de Direito da USP. Agradeço ainda pela confiança depositada, pelos ensinamentos durante a orientação do presente trabalho e por tantos outros que muitas vezes suplantam a teoria jurídica. A oportunidade e o incentivo em integrar o PAE acabaram sendo fundamentais não apenas para minha experiência acadêmica, mas certamente pelo lado pessoal e também profissional. Ao final, o processo foi mais do que gratificante.

Agradeço também aos Professores Fernando Dias Menezes de Almeida e Marcos Paulo Veríssimo, membros da banca examinadora de qualificação, pelas relevantíssimas críticas e contribuições que fizeram ao trabalho.

Aos amigos Caio de Souza Loureiro, Bruno Moreira Kowalski, Diego Gonçalves Fernandes e Daniel Salomoni sou grato pela convívio e risadas diárias. Logicamente que dali saem também muitas ideias e debates jurídicos extremamente interessantes. Mas a diversão acaba tornando os dias mais fáceis e agradáveis.

A respeito do presente trabalho, de grande importância foram as ideias iniciais trocadas com Caio de Souza Loureiro e Danilo Tavares da Silva. Embora frontalmente contrário a quase tudo que aqui se defende, as discussões bem humoradas que travei com Danilo, e também com Caio, acabaram tornando o tema mais desafiador e ao mesmo tempo interessante. Também devo ao auxílio prestado por Clarissa Ferreira de Mello Mesquita, que leu e fez importantes contribuições ainda na fase de qualificação do trabalho. À Bruna Diniz Picon e à Cícera Regina Pereira da Silva ficam os agradecimentos pela ajuda com a bibliografia.

Agradeço também aos sócios e amigos da Manesco, Ramires, Perez, Azevedo Marques - Sociedade de Advogados pelo convívio, aprendizado diário, 
oportunidade e, sobretudo, pela compreensão com minhas ausências, seja em função das aulas ou então no período de elaboração do presente trabalho. Nesse contexto, devo um agradecimento especial ao Dr. Marcos Augusto Perez por ter acreditado, lá no início, que um garoto mais interessado em surf teria condições de algum dia ter intimidade com o direito administrativo.

À minha família sou grato por tudo. A meu pai devo o exemplo de vida e integridade moral; a minha mãe o amor incondicional e inesgotável; a meu irmão o companheirismo, o exemplo de objetividade bem resolvida e, mais recentemente, o prazer de ser padrinho da Maria Beatriz. A todos agradeço a compreensão com minhas ausências e reiteradas negativas.

Mas certamente quem mais merece figurar neste momento de agradecimentos é minha mulher, Patrícia Prieto Moreira, que apoiou e participou deste projeto desde o início. Dos estudos para as provas de ingresso no Programa de PósGraduação até a conclusão deste trabalho ela esteve sempre presente, apoiando, contribuindo com seu conhecimento e, com muita paciência, compreendendo meus momentos de isolamento. Ao final, sua presença diária ao meu lado tem tornado os dias mais fáceis e difíceis. Fáceis porque seu amor, carinho e cuidado têm sido fundamentais. Difíceis porque tem beirado o insuportável negar sua presença para ficar à frente do computador e dos livros. 


\section{RESUMO}

O trabalho parte da premissa de que é altamente importante se precisar os limites da atividade regulatória exercida pela Administração Pública no Brasil. Embora tenha sempre estado entre nós, a regulação econômica tem ganhado mais e mais relevância ultimamente, em especial nos últimos vinte anos. E da mesma forma como têm crescido de incidência, a regulação produzida cada vez mais demonstra ignorar qualquer preocupação com limites interventivos ou mesmo com a capacidade privada. Pois a tese aqui defendida é que um dos principais limites regulatórios se encontra na ideia de subsidiariedade, aqui entendida como o respeito à capacidade e autossuficiência dos atores privados em implementar pautas de interesse público. Não apenas, defendese ainda que o itinerário ideal para se consagrar a subsidiariedade na atividade de regulação administrativa da economia - dentro do rulemaking regulatório - reside na Análise de Impacto Regulatório - AIR. Com isso, pretendeu-se não apenas defender a existência e juridicidade de uma regra de subsidiariedade da intervenção regulatória administrativa no Brasil, como também definir um critério instrumental para a sua implementação prática.

Palavras-chave: intervenção do Estado no domínio econômico - regulação administrativa - subsidiariedade - Análise de Impacto Regulatório - AIR. 


\begin{abstract}
The work starts from the premise that it is highly important to clarify the limits of the regulatory activity in Brazil. Although it has always been among us, economic regulation has gained more and more importance lately, especially in the past twenty years. And just as it has grown in incidence, the regulation produced shows no concerns about its limits or even with private self-capacity. In this sense, the present study defends that the one of the most important regulatory limit is the idea of subsidiarity, here understood as respect for self-sufficiency and ability of private actors to implement public interest agendas. Not only, it is argued that the ideal itinerary to enshrine the subsidiarity in the regulatory activity of the economy - within the regulatory rulemaking - lies in the Regulatory Impact Analysis - RIA. Thus, it is intended not only to defend the existence and legality of a rule of subsidiarity in the regulatory activity in Brazil, but also set an instrumental criterion for its practical implementation.
\end{abstract}

Keywords: economic intervention of the State - regulation - subsidiarity - Regulatory Impact Analysis - RIA. 


\section{SUMÁRIO}

AGRADECIMENTOS............................................................................................................... 4

RESUMO ............................................................................................................ 6

INTRODUÇÃO ............................................................................................................................... 8

CAPÍTULO I. INTERVENÇÃO DO ESTADO NO DOMÍNIO ECONÔMICO................. 12

I.1. INTERVENÇ̃̃O DO ESTADO NO DOMÍNIO ECONÔMICO: PREMISSAS E FUNDAMENTO ........ 12

I.2. PAPEL DO ESTADO NA ECONOMIA: DO LAISSEZ FAIRE AO PÓS NEOLIBERALISMO .............. 16

I.3. MODALIDADES DA INTERVENÇÃ̃ ESTATAL DO DOMÍNIO ECONÔMICO ................................ 25

I.4. POR QUE É IMPORTANTE A EXISTÊNCIA DE LIMITES INTERVENTIVOS? ................................. 30

CAPÍTULO 2. REGULAÇ̃̃O ECONÔMICA: CONCEITUAÇÃO, FUNDAMENTOS E PRINCIPAIS CARACTERÍSTICAS....................................................................................... 39

II.1. CONCEITO AMPLO DE REGULAÇÃO ……………………………………………….... 39

II.2. FUNDAMENTOS JURÍDICOS E CARACTERÍSTICAS DA REGULAÇÃO ECONÔMICA NO BRASIL

II.2.1. Conceito de regulação adotado no trabalho: a regulação administrativa ..................... 46

II.3. REGULAÇÃO E AUTORREGULAÇÃO ………………………………………………...... 48

II.4. FUNÇÕES DA REGULAÇ̃̃O ADMINISTRATIVA DA ECONOMIA: A COMPATIBILIDADE DA LIVRE INICIATIVA COM OS OBJETIVOS DA ORDEM ECONÔMICA …………………………….... 50

II.5. SOBRE A IMPORTÂNCIA DE SE ESTABELECER LIMITES À INTERVENÇÃO REGULATÓRIA ADMINISTRATIVA NA ECONOMIA.................................................................................... 54

CAPÍTULO III. A SUBSIDIARIEDADE CORRETAMENTE COMPREENDIDA.......... 65

III.1. SUBSIDIARIEDADE: ORIGEM, INCOMPREENSÃO E MALEABILIDADE INSTRUMENTAL ..... 65

III.2. CONCEPÇ̃̃O ATUAL DA SUBSIDIARIEDADE E SEUS CAMPOS DE APLICAÇÃO ..................... 70

III.3. NOTA CONCEITUAL: SUBSIDIARIEDADE COMO REGRA OU COMO PRINCÍPIO? ?................... 78

III.4. AS CRÍTICAS CONTEMPORÂNEAS AO VETOR DE SUBSIDIARIEDADE …………………..... 83

III.4.1. Insubsistência das críticas e afirmação da subsidiariedade como vetor de restriçãao interventiva estatal no domínio econômico .............................................................................. 85

III.4.1.a. Um debate que reproduz em grande parte as discussões travadas em Portugal após a revisão constitucional de 1982 ....................................................................... 85

III.4.1.b. Críticas baseadas em uma visão caricata da subsidiariedade ............................. 88

III.4.1.c. Compreensão fundamentalista ou neutra da ordem econômica? A confusão entre o conceito de subsidiariedade e sua utilização prática ………………………………….. 92

III.4.1.d. Desconfiança dos atores econômicos privados ……………………………….... 96

III.5. AFIRMAÇÃO DA SUBSIDIARIEDADE NO DIREITO BRASILEIRO: PERSPECTIVAS TEÓRICA,

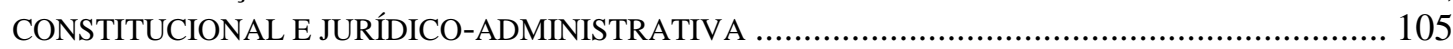

III.5.1. Substrato teórico da subsidiariedade .................................................................. 105

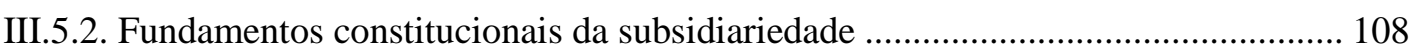

III.5.2.a. Livre iniciativa como direito fundamental .......................................................... 109

III.5.2.b. Fórmula 1: inexistência de um direito da Administração Pública de intervir na

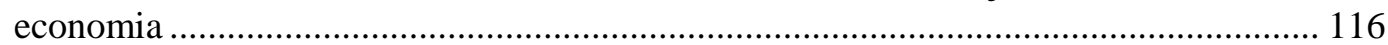

III.5.2.c. Fórmula 2: livre iniciativa como direito fundamental, ponderação, proporcionalidade e subsidiariedade ……………………………………………. 118

III.5.3. Fundamento jurídico-administrativo da subsidiariedade ...................................... 123

III.5.4. Subsidiariedade, regulação administrativa da economia e concretização................ 126 
CAPÍTULO IV. A SUBSIDIARIEDADE CONCRETAMENTE IMPLEMENTADA: A ANÁLISE DE IMPACTO REGULATÓRIO_.......................................................... 128

IV.1. SUBSIDIARIEDADE EM DOIS MOMENTOS: NA VERIFICAÇÃO DO OBJETIVO PÚBLICO A SER

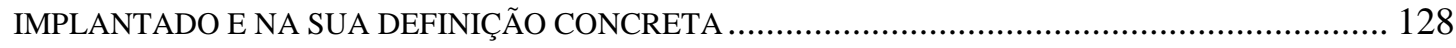

IV.2. A ANÁLISE DE IMPACTO REGULATÓRIO - AIR ......................................................... 130

IV.2.a. As preocupações com a melhora da qualidade da regulação e as experiências

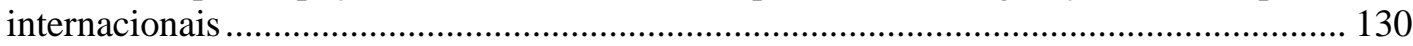

IV.2.b. O que é a Análise de Impacto Regulatório - AIR?.............................................. 134

IV.2.c. A Análise de Impacto Regulatório - AIR e a subsidiariedade da intervenção

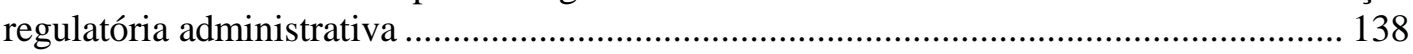

IV.2.d. A AIR no Brasil: o Decreto n ${ }^{\circ} 4.176 / 02$ e o PRO-REG ........................................... 141

IV.3. PAUTAS PARA A PROCEDIMENTALIZAÇÃO DO VETOR DA SUBSIDIARIEDADE NA AIR . 146 IV.3.a. A importância da identificação exata da situação de fato indesejável e do norte a ser

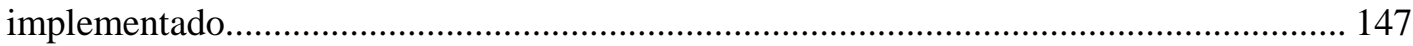

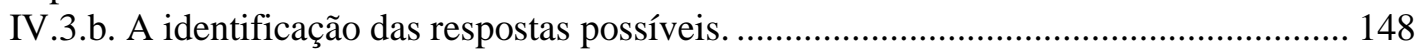

IV.3.c. Realização de consultas públicas sobre as diferentes alternativas regulatórias ..... 149

IV.3.d. A importância de escolha regulatória consciente e respeitadora da autossuficiência

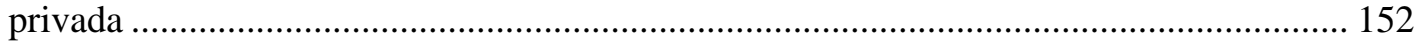

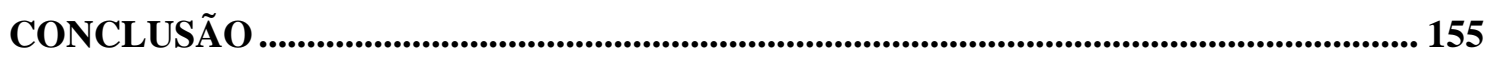

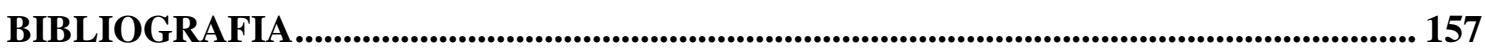




\section{INTRODUÇÃO}

A atuação do Estado na economia não só no Brasil mas em todo o mundo sempre se mostrou fundamental. Em maior ou menor grau, permeado por ideais intervencionistas ou vincado em pensamentos tidos como liberais, sempre esteve presente o Estado como importante elemento de demarcação entre o que é legítimo e desejável em termos econômicos ${ }^{1}$. Como há muito ensinava Alberto VENÂNCIO FILHO usando as palavras de Pedro Gual Villabí, "o econômico esteve sempre subordinado ao político, que, inclusive, quando a economia é deixada num regime de liberdade, é porque a política entende que este sistema liberal é o que convinha aos interesses sociais e quando a política entendeu que devia sujeitá-la, o fez sem maior dificuldade" ${ }^{2}$.

Entretanto, o presente trabalho não busca abordar temas como o tamanho ideal do aparato estatal ou quanto de intervenção se mostraria desejável em determinado setor da economia à luz de alguma interpretação específica da Constituição Federal. Não nos move nenhum ímpeto de ordem ideológica ou de preferência pessoal acerca do protagonismo estatal em seara econômica.

O que se almeja com o presente texto é perquirir um tema que tem sido afirmado e reafirmado mas nem sempre com a devida profundidade e, muitas vezes, quando tratado, acabou sendo bastante mal compreendido ou em alguma medida distorcido. Referimo-nos aqui ao nível de capacidade interventiva da Administração Pública em face da autossuficiência dos atores privados em implementar pautas de interesse público. Em outras palavras, cuida-se de investigar se é ou não legítimo à Administração instituir normas regulatórias visando determinado objetivo de interesse coletivo sem ter certeza ou, o que é pior, nem mesmo interesse a respeito de eventual capacidade dos atores privados em implementar por conta própria tais valores. Pois a premissa do presente estudo é que de fato, no Brasil, por diversos fatores, a eventual capacidade privada passa longe das pautas de preocupação do regulador.

\footnotetext{
${ }^{1}$ Cf. BOYLER, Robert, Teoria da Regulação: os fundamentos, São Paulo: Estação Liberdade, 2009, páginas 48-54.

${ }^{2}$ A Intervenção do Estado no Domínio Econômico: o direito público econômico no Brasil, ed. facsimilar da de 1928, Rio de Janeiro: Renovar, 1998, página 4.
} 
O tema versa, portanto, sobre o que se costumou chamar de "princípio da subsidiariedade" (que particularmente preferimos chamar apenas de subsidiariedade, conforme adiante será melhor explicado), aplicado como limite à intervenção regulatória instituída pela Administração Pública em setores da economia. Significa dizer que somente se mostra legítima a regulação administrativa da economia acaso comprovada a incapacidade dos próprios atores econômicos em garantir os objetivos buscados pela norma regulatória vislumbrada. Mal compreendido, esse vetor de subsidiariedade pode levar à crença de que se está a defender um determinado tamanho de Estado, o que não é verdade.

Assim, dado o próprio objeto de estudo que se propõe, mostrar-se-ão de obrigatório enfrentamento questões marginais tortuosas como a seara econômica enquanto espaço naturalmente privado, a capacidade interventiva geral do Estado, a regulação econômica como mecanismo de condução da economia, as incorretas interpretações feitas ao longo dos anos sobre a ideia de subsidiariedade, bem como sobre sua eventual aderência ao regime constitucional brasileiro (não necessariamente nessa ordem). Ao final, procuraremos apontar um caminho para a efetivação desse vetor de subsidiariedade na regulação econômica que nos parece não apenas possível, mas certamente vocacionado.

Assim, como itinerário do texto que se segue, no Capítulo 1 trataremos da intervenção do Estado na ordem econômica como gênero da atividade estatal, abordando desde aspectos relacionados à terminologia utilizada, as diversas teorias acerca do protagonismo do Poder Público na economia que acabaram prevalecendo ao longo dos anos, as modalidades interventivas admissíveis entre nós e também os riscos de se admitir um intervencionismo que leve à infantilização da sociedade e à substituição da escolha moral dos indivíduos pelas escolhas ditadas pelo Estado.

No Capítulo 2 cuidaremos especificamente da regulação econômica, atividade praticamente imemorial mas que apenas mais recentemente foi apercebida como um tema eminentemente de direito administrativo. Aqui procuraremos cuidar de sua conceituação, dos fundamentos jurídicos e características do que se costumou chamar de moderna regulação econômica, bem como tentaremos delimitar o conceito com o qual se trabalhará no texto, que é a regulação administrativa da economia. Não 
obstante, assuntos conexos e interdependentes como a autorregulação e as próprias funções da regulação econômica serão igualmente abordados. Ao final, serão tecidas algumas notas a respeito da importância de se impor limites à atividade regulatória perpetrada pela Administração Pública, oportunidade em que alguns exemplos serão trazidos para justificar a ideia de que, no Brasil, de modo geral, o próprio regulador não se preocupa com pautas limitativas da atividade, e muito menos com a eventual autossuficiência dos atores privados em implementar os objetivos públicos vislumbrados ao setor.

No Capítulo 3 cuidaremos enfim do tema da subsidiariedade. De início, será apresentado um panorama geral sobre sua origem e sobre alguns equívocos comumente incorridos a respeito de seu conceito, para então chegarmos ao caráter de regra instrumental que nos parece mais coerente, bem como aos campos de atuação que se valem em alguma medida da ideia de subsidiariedade. A partir daí o texto tratará das críticas mais contemporâneas e contundentes sobre a utilização da subsidiariedade como limite à intervenção estatal no domínio econômico, procurando demonstrar como estas opiniões se mostram comprometidas por uma visão irreal da regra e, acima de tudo, fundadas em uma desconfiança do protagonismo privado oriundo da própria formação do Estado brasileiro, o qual acaba por contribuir para a continuidade de uma concepção autoritária da atividade estatal e que prescinde de muitas justificativas para intervir no domínio econômico.

Não obstante, buscar-se-á ainda demonstrar que a subsidiariedade entre nós se fundamenta sob um viés teórico (fundado na ideia do Estado como criação abstrata dos indivíduos para garantir o atingimento de objetivos não alcançáveis individualmente), um viés constitucional (ligado à concepção da livre iniciativa como um direito fundamental garantido pela Constituição Federal de 1988) e um viés intitulado de jurídico-administrativo, vincado, pois, na ideia de condição-fundamento da atividade administrativa.

Por fim, o Capítulo 4 abordará o instrumento que para nós se mostra como o mais adequado à implementação e efetivação do vetor da subsidiariedade na regulação administrativa da economia, que é a chamada Análise de Impacto Regulatório - AIR. Neste ponto, cuidaremos de tratar das preocupações hodiernas sobre a qualidade da regulação, apresentando a AIR como a resposta adequada a este problema. 
Considerada como pauta praticamente mundial do rulemaking regulatório, serão expostas as possibilidade de se instituir a AIR como mecanismo obrigatório no Brasil. Ao final, sem pretender logicamente criar um procedimento estanque ou uma regra geral, abordaremos de forma propositiva algumas pautas para a instituição de um processo de Análise de Impacto Regulatório - AIR apto a garantir e efetivar de forma eficiente a subsidiariedade na atividade regulatória da economia exercida pela Administração Pública.

Com isso, imagina-se poder demonstrar não só a importância do adequado respeito à subsidiariedade na atividade regulatória como também que a AIR é o instrumento processual adequado ao atingimento dessa finalidade. 


\section{CAPÍTULO I. INTERVENÇÃO DO ESTADO NO DOMÍNIO ECONÔMICO}

\section{I.1. Intervenção do Estado no Domínio Econômico: premissas e fundamento}

O termo intervir significa ingerir com a intenção de exercer influência no seu desenvolvimento, contribuir, estar presente, assistir outrem no cometimento de determinadas atribuições. A intervenção do Estado no domínio econômico representa, pois, a trajetória do Poder Público na condução dos mercados das mais variadas formas, seja prestando serviços públicos, regulando-os, regulando atividades econômicas de diversas matizes, atuando como um próprio agente econômico ou ainda fomentando determinados setores do mercado ${ }^{3}$. Nas palavras de Diogo de Figueiredo de MOREIRA NETO, trata-se justamente do alcance pelo Estado "dos processos de criação, transformação, circulação, distribuição e consumo das riquezas, para lhes impor comandos restritivos e condicionadores, conducentes à realização dos princípios gerais que norteiam a concepção constitucional da ordem econômica" ${ }^{4}$.

Encontra fundamento jurídico no bojo dos artigos 170, 173, 174 e 175 da Constituição Federal. Isso porque o artigo 170 institui o regime de economia de mercado na ordem econômica brasileira, fundado na valorização do trabalho humano e na livre iniciativa de qualquer trabalho, elencando ainda os princípios que devem ser observados na sua condução, ao passo que seu parágrafo único assegura "a todos o livre exercício de qualquer atividade econômica, independentemente de autorização de órgãos públicos, salvo nos casos previstos em lei". Já o artigo 173 trata fundamentalmente dos critérios de admissibilidade da exploração direta pelo Estado de atividade econômica, sendo que o artigo 174 delega ao Poder Público o papel de agente normativo e regulador do mercado, competindo-lhe, assim, as funções de fiscalização,

\footnotetext{
${ }^{3}$ Nesse sentido, segundo Egon Bockmann MOREIRA, "[e]ntende-se a intervenção econômica como toda $e$ qualquer conduta estatal (comissiva e omissiva) que vise alterar o comportamento econômico espontâneo dos agentes privados, seja com fins de prestígio ao mercado concorrencial, seja com fins estranhos ao próprio mercado concorrencial (mas vinculados ao interesso público, tal como definido em lei)." (O Direito Administrativo Contemporâneo e a Intervenção do Estado na Ordem Econômica, in WAGNER JÚNIOR, Luiz Guilherme da Costa (coord.), Direito Público: estudos em homenagem ao Professor Adilson Abreu Dallari, Belo Horizonte: Del Rey, 2004, página 260)

${ }^{4}$ Curso de Direito Administrativo, 15 a ed., Rio de Janeiro: Renovar, 2009, página 411.
} 
incentivo e planejamento. Por fim, estabelece o artigo 175 da CF a competência estatal para a prestação e regulação dos serviços públicos genericamente considerados.

Assim, as premissas óbvias da intervenção estatal na economia parecem ser justamente as de que (i) o domínio econômico não é espaço originalmente estatal, mas palco própria da atuação dos particulares, e (ii) que o Estado atua nesta seara garantindo o atingimento de fins de interesse público não alcançáveis autonomamente pelos agentes privados.

E embora este seja um tema recorrente ao longo do trabalho, parte-se da ideia de que o domínio econômico não é espaço natural da atividade do Estado. Em outras palavras, em um regime constitucional de economia capitalista como parece claramente ser o caso brasileiro, o domínio econômico figura palco próprio da atividade dos particulares, o que denota o caráter de intervenção da atividade estatal ${ }^{5}$.

Há, nesse sentido, uma crítica que, embora reconhecidamente irrelevante, vem tomando corpo e se propõe a questionar o acerto ou não do termo 'intervenção' do Estado na economia. Segundo anota Eros GRAU, tendo em vista que o vocábulo intervenção designa a atuação na esfera de outrem, "o Estado não pratica intervenção quando presta serviço público ou regula a prestação de serviço público. Atua, no caso, em área de sua própria titularidade, na esfera pública" ${ }^{6}$. Ou seja, se prestar serviços públicos, regular sua prestação ou mesmo regular a própria atividade econômica consiste em atividade de titularidade estatal por expressa determinação constitucional (arts. 174 e 175, CF/88), não seria correto dizer que haveria aí intervenção estatal em área alheia, mas mera atuação do Estado em seara própria.

Entretanto, não parecem ser assim as coisas, e isso ao menos por dois motivos. Primeiro, e como será devidamente aprofundado mais adiante no texto (notadamente no Capítulo III), a atividade econômica se fundamenta essencialmente no

\footnotetext{
${ }^{5}$ Esta, aliás, a lição de Lúcia Valle FIGUEIREDO, para quem "[d]omínio econômico opõe-se a domínio público, área de abrangência da atividade estatal, enquanto o primeiro refere-se à esfera privada. (...) Intervir é interferir, intrometer-se. A intromissão será devida ou indevida, dependendo do respeito ou desrespeito às balizas constitucionais." (Curso de Direito Administrativo, $9^{a}$ ed., São Paulo: Malheiros Editores, 2008, página 87)

${ }^{6}$ A Ordem Econômica na Constituição de 1988, 12a ed., São Paulo: Malheiros Editores, 2007, páginas 93-94. A referencia ao fato de a discussão ser reconhecidamente irrelevante não denota menosprezo ao debate. Cuida, isto sim, de remissão ao que diz o próprio Professor Titular aposentado de Direito Econômico da Faculdade de Direito da USP sobre o tema, segundo o qual, "se o significado a expressar é o mesmo, pouco importa se faça uso seja da expressão - atuação (ou ação) estatal - seja do vocábulo intervenção" (A Ordem Econômica na Constituição de 1988, op. cit., página 93).
} 
exercício da liberdade dos indivíduos privados, tendo como expressão elementar o mercado. O Estado, portanto, ao extrair parcela da atividade econômica do domínio privado e instituir um serviço público, regulá-lo ou mesmo regular uma determinada atividade econômica atua intervindo, isto é, ingerindo-se de alguma forma em seara que não lhe é própria.

Certo é que todas essas atividades configuram funções estatais por excelência (prestação de serviços públicos e regulação da prestação de serviços públicos/atividade econômica), mas o fato é que têm por objeto a condução de espaço que não é originalmente seu, de modo que o conceito de intervenção acaba por traduzir tão somente a influência política estatal sobre esse espaço exógeno que é a economia ${ }^{7}$. Como lembra Cabral de MOCADA, "[a] relação económica é pois uma relação entre sujeitos individuais, dispondo estes de sua capacidade de direito privado para o seu tratamento. Por ser assim, a fonte da actividade económica é a vontade privada e o seu critério o do interesse privado" ${ }^{2}$. Daí porque ser o Estado, por definição, um ente que sempre e em todo caso intervém no domínio econômico 9 .

Em segundo lugar, também do ponto de vista dogmático a crítica é infundada. Isso porque, é inquestionável reconhecer o notável consenso doutrinário existente acerca da expressão "intervenção do Estado no domínio econômico". E como enunciado dogmático que é, o termo funciona também através dos sistemas de estabilização e de descarga descritos por Robert ALEXY, em que se utiliza os enunciados já aceitos, evita-se novas discussões - que poderiam levar a resultados diferentes a cada vez - e desoneram o interlocutor de dar sempre e toda vez as mesmas

\footnotetext{
${ }^{7}$ Cf. MOREIRA, Vital, A Ordem Jurídica do Capitalismo, $3^{\mathrm{a}}$ ed., Coimbra: Centelho, 1987, páginas
} 197-203.

${ }^{8}$ MONCADA, Luís S. Cabral de, Direito Económico, $4^{\mathrm{a}}$ ed., Coimbra: Coimbra Editora, 2003, página 20.

${ }^{9}$ GIANNINI, Massimo Severo, Diritto Amministrativo, vol. I, $2^{\text {a }}$ ed., Milão: Giuffrè, 1988, páginas 4852, em especial páginas 50-51, da qual se extrai a seguinte passagem: "Uma opinião muito difundida de fato apresenta a situação do Estado democrático não no modo que foi proposta, mas sim em termos voluntarísticos, afirmando que o Estado da 'abstenção' se tornaria 'intervencionista'. Tal opinião é em verdade a popularização de uma tese econômica de direção liberal, a qual não tem mais havido correspondência na realidade jurídica ou sociológica. Esses teóricos sustentavam que o Estado não deveria 'intervir' em matéria econômica, mas apenas manter a ordem, realizar as obras de infraestrutura e encarregar-se da defesa. A realidade efetiva era bastante diversa, uma vez que também o Estado censitário utilizou o instrumento fiscal com a finalidade de regular a economia (ordenamento dos registros, operações aduaneiras e tributação indireta), conhecia os instrumentos de incentivo e desincentivo (benefícios fiscais, reembolso de despesas, prêmios), conhecia as manobras monetárias e em boa parte também as de crédito. O Estado é, por definição (enquanto ente político), um ente que 'intervém' na economia de sua comunidade" - tradução livre. 
explicações sobre o objeto tratado ${ }^{10}$. Isso, entretanto, não torna perene tais conceitos. Afinal, como observa ALEXY, a possibilidade de alteração dos conceitos enraizados independe de meros bons argumentos, uma vez que "[a]s razões em prol da nova solução devem ser tão boas para justificar não só a nova solução, mas também para romper com a tradição" ${ }^{11}$.

Em outras palavras, a alteração do termo 'intervenção' e os conceitos já enraizados que ele representa apenas se mostraria razoável caso a nova nomenclatura proposta possuísse enormes benefícios explicativos que a justificassem, ao mesmo passo que demonstrassem os equívocos atuais, o que não é o caso. Isso porque, dizer que a prestação de serviços públicos e a regulação econômica configuram mera atuação estatal em área que lhe é própria, além de ignorar que o mercado é essencialmente privado, falha como regra geral justamente por tomar como base algo que é circunstancial. Ou seja, as atividades interventivas estatais hoje verificadas no Brasil são produto de sua própria história e resultado de opções constitucionais tomadas durante essa trajetória, não consistindo uma demarcação ex ante entre espaço público e privado que se mostre apto a ser tomado como regra geral. É, por exemplo, também o que defende Vital MOREIRA:

"No domínio econômico o estado tem uma função: realizar nele sua tarefa geral de coesão e integração social, pressupondo (e garantindo a través da ordem jurídica e da sua máquina política) um determinado estatuto de relações económicas. As actividades que tem de realizar são historicamente condicionadas por essa mesma função. Tentar circunscrever aí um núcleo natural, partindo do estado, é tarefa destinada a insucesso. A dimensão das tarefas que o estado tem a realizar para cumprir esta função depende das situações históricas da própria economia." 12

Assim, mesmo que houvesse fundamento na crítica, faltar-lhe-ia relevância jurídica para dar razão à proposta de alteração do termo intervenção. De todo modo, os fins dessa atividade interventiva estatal merecem ser analisados com maior detença, o que será feito em tópico próprio.

\footnotetext{
${ }^{10}$ Teoria da Argumentação Jurídica: a teoria do discurso racional como teoria da justificação jurídica, $2^{\mathrm{a}}$ ed., São Paulo: Landy Editora, 2005, páginas 258-261.

${ }^{11}$ Teoria da Argumentação Jurídica, op. cit., página 259.

${ }^{12}$ Cf. A Ordem Jurídica do Capitalismo, op. cit., página 200.
} 


\section{I.2. Papel do Estado na economia: do laissez faire ao pós neoliberalismo}

Embora não se pretenda com o presente trabalho tratar da evolução do pensamento econômico acerca do papel do Estado na economia ${ }^{13}$, é possível defender hoje que os fundamentos elementares da intervenção estatal na economia são $(\boldsymbol{i})$ a garantia de funcionamento do próprio mercado e (ii) a busca pela coesão social dos indivíduos. Para chegar a essa constatação, de forma bastante resumida, apontam os autores que se debruçaram sobre o assunto ter havido alguns períodos relativamente homogêneos e de prevalência de determinadas concepções teóricas que permitem mapear o papel do Estado na economia ao longo do tempo ${ }^{14}$. A proposta aqui, portanto, é tratar rapidamente das teorias que prevaleceram em determinados momentos históricos ${ }^{15}$.

Uma primeira fase que se pode delinear com alguma clareza é a do chamado capitalismo laissez faire, ou do capitalismo liberal de expressão oitocentista, que encontrava no absenteísmo estatal o principal caminho para o desenvolvimento econômico das nações. Ao Estado, como é cediço, cumpria apenas garantir a defesa territorial e a realização da justiça (aqui entendida como o cumprimento das regras legais existentes). Na esteira das lições de Cabral de MOCADA, do ponto de vista jurídico, há nesse período uma clara divisão entre direito público e direito privado, com o predomínio da autonomia da vontade privada na esfera econômica. Sendo, portanto, a relação econômica uma relação entre sujeitos individuais livres:

"A subordinação da actividade económica à vontade do Estado é, neste enquadramento, algo que não faz sentido e que só poderia conduzir à tirania e ao irracionalismo, pois que substituir a vontade do Estado à vontade dos particulares no domínio da atividade económica, equivalia a

\footnotetext{
${ }^{13}$ Sobre o tema ver, por exemplo, HUNT, E. K., História do Pensamento Econômico, $2^{\text {a }}$ ed., Rio de Janeiro: Elsevier, 2005.

${ }^{14}$ Logicamente que não se está falando de países que traçaram caminhos heterodoxos, como por exemplo o Japão, a China e a Coréia do Sul. Cuida-se aqui do pensamento que prevaleceu na maioria dos países. E o Brasil, ainda que de forma tardia e bastante conturbada, faz parte desse elenco dito majoritário.

${ }^{15}$ Parece-nos mais interessante e adequado abordar o tema sob a perspectiva das teorias que prevaleceram em determinados momentos da história do que à luz dos chamados papéis do Estado (os tais Estados liberal, social, intervencionista, regulador, etc.), que é o que tem tradicionalmente prevalecido. De um lado porque é difícil encontrar um país que tenha efetiva e integralmente em algum momento adotado os modelos estanques de Estados abordados pela doutrina. Em segundo lugar porque foram justamente as teorias econômicas que deram luz a tais modelos.
} 
retirar à esfera da liberdade individual um domínio de aplicação, a economia, essencial para a sua realização, suprimindo a liberdade individual em nome da arbitrariedade dos poderes públicos, cuja actuação, no domínio da economia, só poderia além do mais conduzir ao desperdício, dado que insensível a ideia de lucro, configurado como o único critério racional da atividade económica." 16

O início da Primeira Guerra Mundial marca também o começo de uma tendência à intervenção estatal mais significativa. Isso porque, conforme ensina Fábio Konder COMPARATO, a partir de 1914 a guerra como conceito deixava de ser uma questão marginal, de interesse exclusivo de determinados grupos sociais (e que, portanto, podia ser desenvolvida paralelamente a outras atividades das nações), tornando-se fenômeno social totalitário que submetia a seus fins todas as tarefas e ocupações. Com isso, não era mais possível ao Estado manter-se indiferente à evolução das atividades econômicas ou às decisões dos agentes econômicos, "[c]umpria, ao contrário, submetê-los antes de tudo às exigências da guerra" ${ }^{17}$.

Mas foi mesmo a crise de 1929 iniciada nos Estados Unidos a grande responsável por fazer incidir um intervencionismo estatal bastante mais intenso, permeado não apenas de regras de garantia de funcionamento da economia como também dos próprios objetivos sociais das nações, buscando com isso justamente repor as perdas resultantes da quase paralisia dos meios de produção mundial ${ }^{18}$. Esse período, como escreve Vital MOREIRA, fez a economia se tornar uma questão fundamental de governo na maior parte dos países ${ }^{19}$. Nos EUA houve a implantação do New Deal rooseveltiano, que nada mais foi do que um programa governamental interventivo em

${ }^{16}$ Cf. MONCADA, Luís S. Cabral de, Direito Económico, 4a ed., Coimbra: Coimbra Editora, 2003, páginas 18-21.

${ }^{17}$ O Indispensável Direito Econômico, in Ensaios e Pareceres de Direito Empresarial, Rio de Janeiro: Forense, 1978, páginas 455-456.

${ }^{18}$ Cf. COMPARATO, Fábio Konder, O Indispensável Direito Econômico, op. cit., página 456-457.

${ }^{19}$ Auto-Regulação Profissional e Administração Pública, Coimbra: Almedina, 1997, p. 18. Segundo COMPARATO, "[a] Crise de 1929, colhendo de improviso as economias nacionais que mal se recompunham das conseqüências da grande guerra, e espraiando largamente seus efeitos sobre as economias coloniais periféricas, representou o verdadeiro dobre de finados do clássico 'laissez faire'. Diante da paralisia quase total dos fatores de produção - diminuição do valor do comércio internacional da ordem de 60\%, baixa dos preços internos de 30\%, baixa na cotação das ações em Bolsa de 75\%, desemprego em massa (25\% da mão-de-obra ativa nos Estados Unidos) multiplicação de insolvências a tradicional ausência de iniciativa econômica pública não tardou a desaparecer. A posição estatal de simples árbitro do respeito às regras do jogo econômico não tinha mais razão de ser, desde o momento em que os diferentes protagonistas deixavam de jogar. A se porfiar no otimista laissez faire, ter-se-ia na prática um laissez ne pas faire. Incumbia a alguém reimpulsionar a máquina econômica paralisada, $e$ este alguém só poderia ser o Estado." (O Indispensável Direito Econômico, op. cit., páginas 456-457) 
larga escala ${ }^{20}$; ao passo que a maioria dos países da Europa optaram por caminhos que iam da promoção de regimes autoritários até a instituição de mecanismos de concentração do mercado $^{21}$. O resultado desses fenômenos foi justamente a consagração do modelo de intensa intervenção estatal no domínio econômico ${ }^{22}$.

Veio então a Segunda Guerra Mundial que, após seu término, deixou uma sensação de novo consenso no ar (chamada por alguns autores desenvolvimentistas como postwar consensus). A ideia prevalecente nesse período, que vai de 1945 até meados dos anos 1970, é a de um intervencionismo estatal relativamente moderado (ainda que em alguns países tenha predominado um sistema de intervenção estatal em alguma medida intenso, como na Itália, na Áustria e na Grã-Bretanha), baseado nos ideais de industrialização e de substituição de importações ${ }^{23}$. A partir de 1970, com o fim da Guerra do Vietnã, o abandono do padrão ouro para o dólar norte-americano e a crise do petróleo de 1972, o papel do Estado na economia se intensificou ainda mais, focando agora sua atuação especificamente em indicadores de qualidade de vida e na otimização dos direitos sociais (como saúde, moradia, nutrição, educação, nível de analfabetismo, mortalidade infantil, etc. $)^{24}$.

De um lado, para os países desenvolvidos, foi entre 1970 e 1980 que se iniciou um senso de responsabilidade internacional pelo resultado econômico das demais nações, resultando no fortalecimento de organismos internacionais como o Banco Mundial e a ONU²5. Já para os países do terceiro mundo este foi o momento da

${ }^{20}$ Sobre os impactos do New Deal no sistema norte-americano regulatório, ver MATTOS, Paulo Todescan Lessa, O Novo Estado Regulador no Brasil: Eficiência e Legitimidade, São Paulo: Singular, 2006, páginas 81-90.

${ }^{21}$ Cf. MOREIRA, Vital, Auto-Regulação Profissional e Administração Pública, op. cit., páginas $17-$ 18.

${ }^{22}$ Embora em outro contexto, ver sobre o tema POLANYI, Karl, La Gran Transformación: Critica del liberalismo económico, edição espanhola, Madrid: La Piqueta, 2000, páginas 383-384.

${ }^{23}$ Cf. KENNEDY, David, The “Rule of Law," Political Choices, and Development Common Sense, in TRUBEK, David, M. e SANTOS, Alvaro (ed.), The New Law and Economic Development: A Critical Appraisal, New York: Cambridge University Press, 2006, páginas 98-110.

${ }^{24}$ Cf. KENNEDY, David, The "Rule of Law," Political Choices, and Development Common Sense, op. cit., páginas 110-128. Segundo esse autor, havia uma noção de que o insucesso das medidas pós Primeira Guerra se deveu à resistência da própria burocracia de admitir as implementações normativas desenvolvidas, que foram consideradas pouco pragmáticas e antiformalistas para viabilizar as mudanças sociais intentadas. Daí a solução de construir uma cultura legal mais permeável à teoria jurídica dos livros, de modo a possibilitar a emergência de um corpo administrativo mais conectado com os anseios sociais. (The "Rule of Law, ” Political Choices, and Development Common Sense, op. cit. página 112)

${ }^{25}$ Cf. KENNEDY, David, The “Rule of Law,” Political Choices, and Development Common Sense, op. cit., páginas 113-115. 
constatação da dependência econômica em relação aos países desenvolvidos, o que acabou por fundamentar apelos de mudanças nos sistemas econômico e político mundial. De todo modo, parece ter havido nesse período um significativo fortalecimento do direito internacional e dos direitos humanos, bem como a criação da chamada International Economic Order.

Justamente nesse cenário, segundo os estudiosos do tema, é que surgiu o famoso e de certa forma mal compreendido período intitulado de neoliberalismo, o qual durou provavelmente entre 1981 a 1995. Equivocadamente associado ao que se costumou chamar de Washington Consensus ${ }^{26}$, as ideias tidas como neoliberais predicavam uma redução bastante drástica na incidência interventiva do Estado, o qual deveria muito mais garantir o mercado do que dirigir a economia. Enxergando a própria economia como um mercado universal, sem diferenças significativas entre países desenvolvidos e subdesenvolvidos (afinal, todos buscavam crescer e ter melhor performance econômica devido aos seus próprios talentos ${ }^{27}$ ), o neoliberalismo defendia que o melhor caminho para atingir o tão desejado crescimento seria corrigir os preços em geral, seja pela promoção do livre comercio e da disciplina fiscal, como também principalmente pela remoção de toda e qualquer distorção criada pela intervenção estatal.

\footnotetext{
${ }^{26} \mathrm{O}$ termo Washington Consensus decorre da uniformidade de conceitos sobre política econômica que existiu durante determinado período entre o Tesouro Norte-Americano, o Departamento de Estado daquele país, as Aid Agencies, o FMI e o Banco Mundial, todos eles sediados em Washington. Segundo John WILLIAMSON, economista britânico que em 1989 criou o termo, tratava-se de período em que se buscava mapear as soluções possíveis para os problemas de endividamento dos países da América Latina. Foram, então, apontadas as principais sugestões para desendividar os países do terceiro mundo, consubstanciadas em dez pautas em ordem decrescente de importância, e que consistiam no seguinte: disciplina fiscal, reordenação de despesas públicas, reforma tributária, liberalização das taxas de juros, a instituição de uma taxa de cambio competitiva, liberalização do comercio internacional, liberalização do investimento estrangeiro direto, privatização, desregulamentação de determinados setores, facilitação da aquisição da propriedade (What Washington Means by Policy Reform, in WILLIAMSON, John (ed.), Latin American Adjustment: How Much Has Happened?, Washington: Institute for International Economics, 1990, páginas 7-20). Segundo anota o próprio Williamson, é incorreta a intercambialidade entre o neoliberalismo e o que defendia o Washington Consensus (cf. A Short History of the Washington Consensus 1, in SERRA, Narcís e STIGLITZ, Joseph, The Washington Consensus Reconsidered, Nova Iorque: Oxford University Press, 2008, páginas 14-30)

${ }^{27}$ Ao tratar desse período, KENNEDY aponta que "economias desenvolvidas e subdesenvolvidas não são, nesta visão, fundamentalmente diferentes umas das outras - não há necessidade para um 'desenvolvimento' econômico especial. Não há um caminho ao desenvolvimento, não há estágios préfixados, não há 'take-off', não há nada mágico sobre industrialização. Há apenas pessoas que possuem coisas, que transacionam, e que desse modo as movimentam de usos menos produtivos para usos mais produtivos. Mesmo o termo 'desenvolvimento' acaba perdendo posição nesse período, substituído para o termo mais técnico 'eficiência', usado tanto em uma acepção técnica como no sentido de um vago sinônimo para a maximização da performance econômica." (The "Rule of Law," Political Choices, and Development Common Sense, op. cit., página 129 - tradução livre)
} 
Assim, predicavam os defensores da teoria neoliberal ${ }^{28}$ certamente uma espécie de volta ao laissez faire (daí a nada original alcunha de neoliberal), mas não de forma integral. Isso porque, clamava-se também por alguma intervenção estatal, necessária para garantir a adequada condução do mercado, como em matéria de direito criminal, direito antitruste, regulamentação fiscal e monetária, etc ${ }^{29}$. Segundo observa Linda WEISS, mesmo com a implementação das agendas neoliberais de diminuição do aparato interventivo, de um modo geral, "Estados continuam a fomentar novos sectores de crescimento, subsidiar a inovação e atualização tecnológica, investir em infraestrutura, financiar educação e formação, incluindo políticas ativas de mercado de trabalho, e regular a indústria e as finanças em distintas formas para reforçar a competitividade nacional - tudo em forte contraste com as previsões da visão de estado reprimido" ${ }^{30}$.

Mas como também é de amplo conhecimento, as teses chamadas de neoliberais acerca da intervenção estatal na economia também já caíram em pleno descrédito. O devastador choque institucional russo (market shock), as crises do Leste Europeu, a situação emergencial a que chegaram os países da América Latina e a crise financeira asiática, todos tendo como ponto de partida as soluções genéricas vendidas pelo programa neoliberal, eventos verificados basicamente ao final dos anos 1990s, propulsionaram entre outras coisas uma severa reflexão acerca do relacionamento Estado/economia. Não obstante, a crise que acometeu o sistema financeiro americano nos fins de 2007, atingindo também a grande maioria dos países com economias menos reguladas, acabou por contribuir ainda mais ao descrédito das teses neoliberais. Daí a

\footnotetext{
${ }^{28}$ Tenha-se em mente, portanto, que o neoliberalismo não passou disto, de uma teoria econômica prevalecente em determinado período da história do pensamento econômico mundial e que já restou superada. Essa constatação, entretanto, acaba por confrontar parte da doutrina publicística brasileira que insiste em fetichizar a teoria neoliberal, supervalorizando-a e a tratando como a origem de todos os males do século XXI. Para uma visão bastante reduzida do neoliberalismo como teoria, e que, por conseguinte, ignora completamente sua inserção no contexto econômico mundial, consulte-se por todos MARTINS, Ricardo Marcondes, Regulação Administrativa à Luz da Constituição Federal, São Paulo: Malheiros Editores, 2011, páginas 137-191.

${ }^{29}$ Cf. KENNEDY, David, The "Rule of Law," Political Choices, and Development Common Sense, op. cit., página 132.

${ }^{30}$ Is the state being 'transformed' by globalization?, in WEISS, Linda (org.), States in the Global Economy: Bringing Domestic Institutions Back In, Cambridge: Cambridge University Press, 2003, página 296.
} 
levar Fábio NUSDEO a dizer que o início de 2010 é marcado por um novo consenso: "o de que o Consenso de Washington se desfez".31.

Nesse sentido, é pertinente constatar que o protagonismo estatal no domínio econômico é eminentemente cíclico e pendular, intercalando constantemente períodos de maior intervencionismo com períodos de maior liberdade. $\mathrm{Ou}$, como apontava há muito Luiz Carlos BRESSER PEREIRA, deve-se perceber que " $a$ intervenção estatal expande-se e contrai-se ciclicamente, e que a cada novo ciclo o modo de intervenção muda" ${ }^{32}$, constatação esta que torna (ou deveria tornar) o debate ideológico uma questão marginal. De todo modo, o importante é perceber que dessas experiências, algumas lições vão sendo apreendidas.

Atualmente, há a noção de que mercados não se criam sozinhos, que podem eventualmente falhar, que possuem imperfeições naturais e que mecanismos jurídico-estatais podem ser necessários para criar a infraestrutura necessária para o seu correto funcionamento ${ }^{33}$. Em outras palavras, cabe ao Estado intervir no domínio econômico justamente para dar possibilitar a existência e manutenção do mercado, o que se dá em alguma medida pelo fomento, correção, controle e conformação do funcionamento espontâneo da decisão econômica privada ${ }^{34}$. Ou, como afirma acertadamente Vital MOREIRA, trata-se de verificar que a "performance da economia - apesar de predominantemente privada - é uma responsabilidade do Estado"35.

Mas não é só. A intervenção do Estado no domínio econômico não pode também ser indiferente a parâmetros de justiça social, de redistribuição de renda e

\footnotetext{
${ }^{31}$ Curso de Economia, 6 ${ }^{\text {a }}$ ed., São Paulo: Revista dos Tribunais, 2010, página 223.

${ }^{32}$ O caráter cíclico da intervenção estatal, in Revista de Economia Política, vol. 9, n 3 , São Paulo: Editora 34, jul/set 1989, página 121.

${ }^{33}$ Cf. TRUBEK, David M. e SANTOS, Alvaro, Introduction: The Third moment in Law and Development Theory and the Emergence of a New Critical Practice, in TRUBEK, David M. e SANTOS, Alvaro (ed.), The New Law and Economic Development: A Critical Appraisal, New York: Cambridge University Press, 2006, páginas 10-12.

${ }^{34}$ Cf. MONCADA, Luís S. Cabral de, Direito Económico, op. cit., páginas 18-21.

${ }^{35}$ Auto-Regulação Profissional e Administração Pública, op. cit., página 21. Em sentido semelhante e referindo-se especificamente ao Brasil, observa com acerto Egon BOCKMANN MOREIRA que "[a]pesar de o Estado brasileiro ser um estranho ao domínio econômico, a sua relação com a economia não é exclusivamente um acessório da ideia liberal de um mercado perfeito. Antes do que isso, é oriunda de uma concepção diversa: a de que há falhas estruturais e comportamentais no próprio mercado (imperfeito como de fato o é)." (O Direito Administrativo da Economia, a Ponderação de Interesses e o Paradigma da Intervenção Sensata, in CUELLAR, Leila e MOREIRA, Egon Bockmann, Estudos de Direito Econômico, Belo Horizonte: Fórum, 2004, página 59)
} 
de garantia de efetivação dos direitos fundamentais e sociais da população. É dizer, se por um lado a atuação estatal em seara econômica tem como substrato o adequado funcionamento do mercado, de outro não pode ser indiferente ao resultado obtido por esse mesmo mercado para cada indivíduo ou classe de indivíduos inseridas na sociedade, o que acaba por legitimar a que o Estado controle mesmo os resultados alcançados pelo jogo econômico.

\title{
Nas palavras de Luis S. Cabral de MONCADA:
}

\begin{abstract}
"Do ponto de vista do moderno Estado intervencionista o funcionamento do mercado não é encarado como um jogo de soma-zero em que os participantes estão colocados na situação em que o que uns ganham é o que os outros perdem, que é como quem diz, numa situação de puro conflito. Pretende-se, pelo contrário, que do funcionamento do mercado resulte numa situação materialmente adequada para cada um, aceitável segundo os critérios da justiça social e que se concretiza na melhoria da situação dos mais desfavorecidos. Daí que a actividade privada deva ser corrigida pelas instituições políticas, sendo a norma jurídica o instrumento dessa tarefa. Por sua vez, tal tarefa pode exigir não apenas uma atividade de correcção mas também de controlo ou de conformação da mesma, tudo dependendo do modelo concreto de Estado intervencionista instituído. ${ }^{36}$
\end{abstract}

Portanto, outro vetor a fundamentar e, por assim dizer, legitimar a própria atividade intervencionista estatal na economia decorre da busca da justiça e coesão social, isto é, no adequado padrão de distribuição de riqueza entre os indivíduos da sociedade, de modo a possibilitar-lhes a fruição integral dos direitos fundamentais e sociais garantidos constitucionalmente ${ }^{37}$.

E isso não por simples benemerência ou retórica. Trata-se, por um lado, de simplesmente efetivar diversas normas constitucionais que reconhecem a pobreza dos indivíduos e a desigualdade social como problemas a serem solucionados

\footnotetext{
${ }^{36}$ Direito Económico, op. cit., página 35.

${ }^{37}$ Como anota a doutrina espanhola, "cierto grado de intervencionismo parece necesario a fin de satisfacer un mínimo de derechos subjetivos a los ciudadanos, a fin de asegurar la «procura existencial» de los mismos, ya que el advenimiento del Estado-Providencia ha traído consigo el aseguramiento por el Estado de determinadas prestaciones garantizadoras de un mínimo vital, existencial, a sus ciudadanos. Así pues, toda intervención del poder público en el mundo socioeconómico deberá estar justificada en la intención de garantizar ese mínimo existencial a todos sus ciudadanos, o lo que es lo mismo, en la satisfacción de determinadas finalidades de interés general. Es decir, toda modalidad de intervención tendrá como fin último la consecución de un interés público." (FELIÚ, José María Gimenu, Legalidad, Transparencia, Control y Discrecionalidad en las Medidas de Fomento del Desarrollo Económico, in Revista de Administración Pública, $\mathrm{n}^{\circ}$ 137, Madrid: Centro de Estudios Políticos y Constitucionales, mai/ago 1995, página 149)
} 
pelo Estado, como determina o inciso III do artigo $3^{\circ}$ da Constituição Federal ${ }^{38}$. Afinal, se o Estado existe apenas para servir os cidadãos - e este tema será estressado mais adiante -, bastante evidente que não poderá se manter indiferente ao resultado de cada indivíduo no jogo econômico, muito menos manter-se apático diante da negação dos direitos individuais e sociais de cada um. Por outro lado, é sabido que a alta desigualdade de renda entre os habitantes funciona como efetivo obstáculo ao crescimento econômico de um país - tanto teoricamente quanto empiricamente a igualdade tem sido compreendida como um ingrediente vantajoso no processo de desenvolvimento econômico das nações ${ }^{39}$ - , o que torna a justiça distributiva um vetor absolutamente fundamental na intervenção do Estado no domínio econômico. Lembrese que segundo o Relatório do Desenvolvimento Humano de 2011 do PNUD, o Brasil figura atualmente como o $8^{\circ}$ país com maior desigualdade social do mundo, à frente apenas de Comores, Haiti, Angola, Colômbia, África do Sul, Honduras e Bolívia ${ }^{40}$.

\footnotetext{
${ }^{38}$ Referido dispositivo estabelece constituir um dos "objetivos fundamentais da República Federativa do Brasil: (...) III - erradicar a pobreza e a marginalização e reduzir as desigualdades sociais e regionais".

${ }^{39}$ Cf. COUTINHO, Diogo R., Linking Promises to Policies: Law and Development in an Unequal Brazil, in The Law and Development Review, vol. 3, $\mathrm{n}^{\circ}$ 2, página 4, disponível em: http://www.law.wisc.edu/gls/documents/diogo coutinho paper.pdf. Conforme explicam Tony ADDISON e Giovanni Andrea CORNIA, a relação entre desigualdade e crescimento econômico não é linear, mas côncava, ou seja, em um nível muito baixo ou muito alto acaba sendo altamente prejudicial. Pouca desigualdade, resultado natural de uma distribuição de renda muito compacta e que não reflete adequadamente diversos níveis de mérito, talento e esforço dos indivíduos, resulta em inibição do crescimento por razões como a perda de incentivo, distorções, oportunismo e comodismo. É o caso do sistema de pagamento soviético, cuja relação entre salário e esforço pessoal, por ser inexistente, parece ter criado graves desincentivos ao trabalho, crescimento da aversão ao risco, erosão da disciplina laboral, etc. Do mesmo modo, um alto nível de desigualdade implica também em desvio da renda laboral do sistema de recompensa baseado no mérito, no talento e no esforço de cada indivíduo. Aqui, entretanto, o que ocorre é que o acesso desigual à educação, terra, crédito e seguro gera custos de transação bastante significativos. Além da própria perda de recursos (a concentração de terra impulsiona o pobre a pensar a curto prazo, gerando problemas ambientais - salários perto ou abaixo da linha de subsistência podem neutralizar os próprios incentivos ao trabalho, aumentar a informalidade, ampliar custos de supervisão e sepultar a eficiência), um gap muito grande entre ricos e pobres aumenta exponencialmente o reentseeking, o comportamento predatório da sociedade e a própria criminalidade. Isso aumenta também logicamente os custos de transação para a segurança dos negócios e o cumprimento dos contratos, do mesmo modo que fragilisa a segurança dos direitos de propriedade. $\mathrm{E}$ a análise empírica procedida pelos autores indica que, tirando o Cazaquistão e a China, em média, os países que experienciaram grandes aumentos na desigualdade de renda de seus cidadão foram mais suscetíveis a terem uma relevante desaceleração ou mesmo estagnação de seu crescimento econômico. (Income Distribution Policies For Faster Poverty Reduction, in United Nations University - World Institute for Development Economics Research - UNU- WIDER, Discussion Paper $n^{\circ}$ 93/2001, páginas 10-20. Disponível em: http://www.wider.unu.edu/publications/working-papers/discussion-papers/2001/en_GB/dp2001-93/_files 178091898299943842/default/dp2001-93.pdf)
}

${ }^{40}$ PNUD, Relatório do Desenvolvimento Humano de 2011, disponível na Internet no endereço: http://hdr.undp.org/en/media/HDR_2011_PT_Complete.pdf. 
Englobadas neste conceito de coesão social estão logicamente as políticas econômicas implementadas pelo Poder Público com viés desenvolvimentista, ou seja, intervenções estatais que tenham por finalidade alcançar determinados objetivos institucionais e econômicos para o crescimento da nação, como a manutenção da balança comercial, o desabastecimento de determinados insumos, minimizar riscos inflacionários, etc. Embora possa parecer uma ampliação muito grande, de nossa parte, em toda essa enorme gama de possibilidades interventivas, o que em última análise visa o Estado é a coesão social e a melhor distribuição de recursos entre os indivíduos. De certa forma, é o que faz também José Afonso da SILVA ao chamar a defesa do consumidor, a defesa do meio ambiente, a redução das desigualdades regionais e sociais e a busca do pleno emprego (objetivos expressos encartados no artigo 170 da Constituição Federal) como princípios de integração, já que "todos estão dirigidos a resolver os problemas da marginalização regional ou social" ${ }^{41}$.

Do ponto de vista normativo, é justamente isso que se depreende do artigo 170 da Constituição Federal brasileira, ou seja, que os grandes vetores da intervenção do Estado no domínio econômico são a garantia de funcionamento do próprio mercado e a busca pela coesão social da nação. Não é outra coisa que se extrai da norma quando se fundamenta a ordem econômica na valorização do trabalho humano e na livre iniciativa, quando se assegura a todos os cidadãos uma existência digna, conforme os ditames da justiça social, e tendo ainda como princípio a soberania nacional, a propriedade privada, a função social da propriedade, a livre concorrência, a defesa do consumidor, a defesa do meio ambiente, a redução das desigualdades regionais e sociais, a busca do pleno emprego e o tratamento favorecido para as empresas brasileiras de pequeno porte. Em outras palavras, de todo o contexto contido no artigo 170 do Texto Constitucional, é possível resumir que a intervenção do Estado no domínio econômico visa a atender dois vetores elementares, vale dizer, a garantia de funcionamento do próprio mercado e a busca pela coesão social da nação.

Cabem, entretanto, duas notas aqui. Em primeiro lugar, importante ressaltar que não se pretende de forma alguma substituir os comandos autorizativos específicos da intervenção estatal dispostos na Constituição Federal (expressos ou não no artigo 170) pelos vetores acima descritos. O que se busca com a presente passagem é

\footnotetext{
${ }^{41}$ Curso de Direito Constitucional Positivo, 33 ${ }^{\text {a }}$ ed., São Paulo: Malheiros Editores, 2010, página 796.
} 
tão somente demonstrar que os resultados da experiência global acerca do papel do Estado na economia se coadunam com o ordenamento brasileiro. Ou seja, quer-se aqui apenas demonstrar que as lições extraídas das experiências mundiais sobre o papel do Estado são de resto aplicáveis ao caso brasileiro, especificamente dispostos no Texto Constitucional.

Em segundo lugar, também não se pretende com isso perenizar as decisões estatais cotidianas em seara econômica nem muito menos capturar o interesse público de modo a estabelecer um modelo econômico predefinido de mais ou menos intervenção. Não é isso. Trata-se simplesmente de apontar quais parecem ser os macro objetivos constantes do ordenamento constitucional no que respeita ao papel do Estado na ordem econômica. Isto é, cuida-se tão somente afirmar que nos termos do Texto Constitucional vigente, a intervenção estatal deve estar atrelada à implementação de objetivos de ordem pública vinculados à satisfação das necessidades coletivas. Quanto a isso não parece haver muitas dúvidas.

\section{I.3. Modalidades da intervenção estatal do domínio econômico}

Como é sabido, existem diversas formas de classificar a atuação do Estado em seara econômica ${ }^{42}$. Entre nós, talvez a mais famosa e difundida seja a classificação feita por Eros GRAU, para quem há três modalidades interventivas, $(\boldsymbol{i})$ a intervenção por absorção ou participação - em que o Poder Público assume integralmente o controle ou apenas parcela do meios de produção e/ou troca em determinados setores do mercado, ou seja, intervém instituindo um monopólio ou simplesmente compete com outros atores privados -, (ii) a intervenção por direção em que o Estado exerce pressão sobre a economia, estabelecendo mecanismos e normas de comportamento compulsório aos atores privados - e (iii) a intervenção por indução -

\footnotetext{
${ }^{42}$ Nesse sentido, fala-nos Diogo de Figueiredo MOREIRA NETO de quatro modalidades interventivas, que seriam a seu ver as regulatórias, as concorrenciais, as monopolistas e as sancionatórias (Curso de Direito Administrativo, op. cit., página 530). Por outro lado, Maria Sylvia Zanella DI PIETRO adota entendimento segundo o qual a "intervenção compreende a regulamentação e fiscalização da atividade econômica de natureza privada (intervenção indireta), bem como a atuação direta por meio de empresas estatais (intervenção direta), o que se dá normalmente por meio das empresas estatais" (Direito Administrativo, 25 a ed., São Paulo: Atlas, 2012, página 56). Já Cabral de MONCADA, além das intervenções diretas e indiretas, menciona também as intervenções globais, setoriais, pontuais, avulsas, imediatas, mediatas, unilaterais e bilaterais (Direito Económico, op. cit., páginas 37-44)
} 
em que o Poder Público manipula os instrumentos de intervenção em consonância conformidade com os regramentos do mercado ${ }^{43}$.

Entretanto, ao invés de focar em classificações teóricas e muito abrangentes, mais conveniente parece abordar o tema analisando as espécies de instrumentos que detém o Estado para intervir no domínio econômico, como faz parte da doutrina. Nesse sentido, conforme ensina Floriano de Azevedo MARQUES NETO $^{44}$ e, em alguma medida, também Gaspar Ariño ORTIZ ${ }^{45}$, pode o Estado intervir na ordem econômica mediante $(i)$ o exercício de mecanismos de polícia econômica, (ii) por meio do fomento de um dado setor, (iii) pela prestação de um serviço público e (iv) pela atividade de gestão econômica ou de produção de bens e serviços.

O poder de polícia econômica implica em que o Estado produza atos ou normas imperativos e coercitivos aos agentes privados, consubstanciadas em limitações e condicionamentos ao exercício de determinada atividade econômica. Segundo ORTIZ, "[i]cluye esta actividad tanto la potestad legislativa como la reglamentaria, con todas sus secuelas de aplicación limitadora y coactiva, o incluso, ablativa, plasmada en instrumentos como las órdenes, licencias, permisos, provisiones, etc ${ }^{\prime 46}$. Trata-se, em verdade, do exercício de poder de polícia tradicional mas com impactos ao exercício de determinada atividade econômica. Aqui, portanto, inclui-se tanto a promulgação de leis conformadoras das atividades econômicas como a regulação econômica propriamente dita, compreendendo também as demais medidas públicas que

\footnotetext{
${ }^{43}$ A Ordem Econômica na Constituição de 1988, op. cit., páginas 148-149.

${ }^{44}$ O Fomento como Instrumento de Intervenção Estatal na Ordem Econômica, in Revista de Direito Público da Economia - RDPE, ano 8, n 32, Belo Horizonte: Fórum, out/dez 2010, página 62.

${ }^{45}$ Principios de Derecho Público Económico, $3^{\text {a }}$ ed., Granada: Comares Editorial, 2004, páginas 301304. Importante observar que ORTIZ ainda inclui nos instrumentos de intervenção estatal na economia a atividade de planejamento econômico e a atividade arbitral. De nossa parte, embora reconheçamos o papel central do planejamento, ele em si não funciona como um mecanismo autônomo de intervenção do Estado no domínio econômico. Trata-se, isto sim, de atividade estatal prévia à intervenção, que tem por finalidade justamente dotar de racionalidade as decisões interventivas de modo garantir a melhor condução do mercado, conformando a decisão individual do ator privado aos interesses públicos a serem alcançados (cf. nesse sentido MARQUES NETO, Floriano de Azevedo e QUEIROZ, João Eduardo Lopes, Planejamento, in CARDOZO, José Eduardo Martins et. al. (orgs.), Curso de Direito Administrativo Econômico, vol. II, São Paulo: Malheiros Editores, 2006, páginas 61-65). Não obstante, a atividade de arbitramento de interesses é inerente à função estatal regulatória, como aponta Diogo de Figueiredo MOREIRA NETO (Direito Regulatório, Rio de Janeiro: Renovar, 2003, páginas 107-108), não se constituindo, portanto, uma modalidade de intervenção autônoma.
}

${ }^{46}$ Cf. Principios de Derecho Público Económico, op. cit., página 302. 
acabam restringindo em alguma medida a livre iniciativa. É dividida ainda em regulação econômica e regulação social, ainda que tal segregação, como veremos mais adiante, não faça muito sentido no Brasil.

De outro lado, a atividade de fomento consiste, nas palavras de Floriano Azevedo MARQUES NETO, na "atividade estatal de incentivo positivo ou negativo a outra atividade desenvolvida por um ou vários particulares, de forma a condicionar o comportamento privado" ${ }^{47}$. Busca-se, com o fomento, justamente estimular ou proteger bens ou serviços considerados como essenciais à coletividade. É positivo o fomento que tem como móvel tornar determinada atividade econômica mais atraente e viável aos particulares envolvidos, utilizando o Estado de uma espécie de mecanismo de direito premial, isto é, uma medida positiva que beneficia quem adota determinada postura considerada adequada pelo Poder Público ${ }^{48}$. Por outro lado, é negativo o fomento quando o Estado, através do abrandamento ou intensificação de medida restritiva, induz, incentiva ou desincentiva determinados atos dos atores privados, buscando com isso desenvolver ou reduzir atividade econômica ${ }^{49}$.

No caso brasileiro, é imperioso verificar que em diversas passagens a Constituição Federal trata do fomento como atividade estatal. Isso se dá, por exemplo, no inciso VIII do artigo 23 (fomento à produção agropecuária e à organização do abastecimento alimentar), no $\S 2^{\circ}$ do artigo 43 (fomento a um mesmo complexo geoeconômico e social, visando o seu desenvolvimento e a redução das desigualdades regionais), no artigo 165 (inclusão na LDO das políticas de aplicação das entidades de fomento), no $\S \S 3^{\circ}$ e $6^{\circ}$ do artigo 216 (fomento à produção e o conhecimento de bens e valores culturais), no artigo 217 (fomento ao esporte), $\S 4^{\circ}$ do artigo 218 (fomento às empresas que invistam em pesquisa, criação de tecnologia adequada, formação e aperfeiçoamento de seus recursos humanos e que pratiquem sistemas de remuneração

\footnotetext{
${ }^{47}$ O Fomento como Instrumento de Intervenção Estatal na Ordem Econômica, op. cit., página 65.

${ }^{48}$ Indesviável aqui a referência à sanções positivas de que nos fala Norberto BOBBIO, ou seja, de atos estatais que "dão vida a uma técnica de estimulo e propulsão a atos considerados socialmente úteis, em lugar da repressão de atos considerados socialmente nocivos" (Da Estrutura à Função: novos estudos de teoria do direito, São Paulo: Manole, 2007, páginas 23-32)

${ }^{49}$ Cf. MARQUES NETO, Floriano de Azevedo, O Fomento como Instrumento de Intervenção Estatal na Ordem Econômica, op. cit, página 65. No mesmo sentido, anota Luis JORDANA DE POZAS que o conceito de atividades de fomento negativas abrangem os "obstáculos o cargas creadas para dificultar por medios indirectos aquellas actividades o establecimientos contrarios a los que ei gobernante quiere fomentar" (Ensayo de una teoría del fomento en el Derecho administrativo, in Revista de Estudios Políticos, $n^{\circ}$ 48, Madrid: Centro de Estudios Políticos y Constitucionales, nov/dec 1949, página 51)
} 
que assegurem ao empregado a participação nos ganhos econômicos resultantes da produtividade de seu trabalho), etc ${ }^{50}$.

Não obstante, quando o Estado avoca a atribuição de oferecer uma atividade como serviço público, seja pelas suas estruturas institucionais seja com o auxílio dos mecanismo de delegação aos particulares (concessão e permissão), automaticamente acaba por intervir na ordem econômica. Como ensina Marçal JUSTEN FILHO:

\begin{abstract}
"O serviço público existe quando uma atividade econômica é necessária de modo direto e imediato à satisfação de direitos fundamentais, que não podem ser promovidos mediante os mecanismos da atuação de mercado próprios da iniciativa privada. Como decorrência, essa atividade é atribuída à titularidade do Estado e submetida ao regime de direito público. Isso acarreta a não-aplicação dos princípios da livre iniciativa e da livre concorrência. $O$ art. 175 da Constituição disciplina a matéria." ${ }^{51}$
\end{abstract}

De um lado, em se tratando de atividade em que o Estado presta diretamente e inadmite competição com particulares, o resultado é a completa extração da atividade do domínio econômico. De outro, acaso delegue a atividade à iniciativa privada, é possível que admita apenas um prestador (delegação em regime de exclusividade, a qual é exceção e não regra, nos termos do que predica o artigo 16 da Lei $\left.\mathrm{n}^{\circ} 8.987 / 95\right)$, ou que admita a concorrência no setor. No primeiro caso, é evidente o caráter interventivo da medida, já que extrai também a atividade do âmbito do mercado. No segundo, ainda que admita diversos prestadores, não raro o Poder Público institui normas regulatórias específicas de forma a organizar e garantir os valores inerentes ao próprio conceito de serviço público (i.e. universalização, continuidade, modicidade tarifária, etc.), hipótese em que determina a obrigatoriedade do preenchimento de determinados requisitos, barreiras de entrada de novos prestadores, limitações ao acesso a novos mercados, obrigações de investimentos e toda a sorte de deveres aptos a garantir a fruição do serviço aos indivíduos. Aqui, de modo bastante simplificado, parece óbvio que ainda que em menor grau, a intervenção estatal se mostra clara pelo

\footnotetext{
${ }^{50}$ Em sentido semelhante, ver MENDONÇA, José Vicente Santos de, Uma Teoria do Fomento Público: critérios em prol de um fomento público democrático, eficiente e não-paternalista, in Revista de Direito da Procuradoria Geral do Estado do Rio de Janeiro, vol. 65, Rio de Janeiro: Procuradoria-Geral do Estado do Rio de Janeiro, 2010, página 119.

${ }^{51}$ Curso de Direito Administrativo, 8 a ed., Belo Horizonte: Fórum, 2012, página 653.
} 
estabelecimento de uma série de formalidades e barreiras ao exercício da livre iniciativa privada em atividade de natureza econômica ${ }^{52}$.

Por fim, no que toca à atividade de gestão econômica ou de produção de bens e serviços, o Estado, neste caso, acaba atuando propriamente como um agente do mercado, produzindo ou comercializando tais utilidades e disponibilizando-os aos indivíduos. Atua aqui de duas formas distintas. Em primeiro lugar, pode o Poder Público intervir no domínio econômico pelo desempenho de atividade econômica em regime de competição e igualdade com os particulares (sem reserva de titularidade ou prerrogativa de império), desde que, conforme estabelece o artigo 173 da Constituição Federal, fundadamente vinculado a imperativos de segurança nacional ou de relevante interesse coletivo. Em segundo, pode ainda o Estado instituir regime de monopólio em determinada atividade, resultando justamente na supressão da livre iniciativa dos atores privados em determinado setor do mercado ${ }^{53}$. Pois em ambos os casos, há intervenção estatal no domínio econômico, seja lançando-se à competição com os particulares, seja excluindo determinado setor da livre iniciativa privada.

Essas, em linhas gerais, são as modalidades de intervenções na economia passíveis de serem realizadas pelo Poder Público. Uma, entretanto, nos preocupa mais, a regulação econômica, que será analisada no próximo Capítulo. Antes, porém, importante nos debruçarmos sobre as discussões a respeito da necessidade ou não de haver limites interventivos à atividade estatal como um todo.

\footnotetext{
${ }^{52}$ Sobre o tema da competição nos serviços públicos ver MARQUES NETO, Floriano de Azevedo, Universalização de Serviços Públicos e Competição: o caso da distribuição de gás natural, in Revista Trimestral de Direito Público - RTDP, n ${ }^{\circ}$ 34, Rio de Janeiro: Malheiros Editores, 2001, páginas 3450; ARAGÃO, Alexandre Santos, Direito dos Serviços Públicos, $2^{\mathrm{a}}$ ed., Rio de Janeiro: Forense, 2008, páginas 407-428; e SCHIRATO, Vitor Rhein, Livre Iniciativa nos Serviços Públicos, Belo Horizonte: Fórum, 2012.

53 "O sentido econômico do monopólio é o de eliminação da concorrência, constituindo-se em uma anomalia de mercado, que tanto pode ocorrer provocada por causas espontâneas como voluntárias. Por outro ângulo, o sentido juspolítico é o de exceção à liberdade constitucional de competição, que, neste caso, também necessita ser constitucionalmente explicitada, pois se trata da instituição de um privilégio para o Estado empresário." (MOREIRA NETO, Diogo de Figueiredo, Curso de Direito Administrativo, op. cit., página 534)
} 


\section{I.4. Por que é importante a existência de limites interventivos?}

A discussão sobre a necessidade ou não de limites à intervenção estatal perpassa tudo o que foi abordado acima e não se limita ao tema das liberdades econômicas, mas envolve também as liberdades dos indivíduos em geral. Como é intuitivo, trata-se justamente de limitar qualquer parcela de liberdade das pessoas mediante mecanismos legais ou infralegais (poder de polícia em sentido amplo) com a finalidade de garantir o atingimento de resultados de interesse público tidos como desejáveis.

A partir do momento em que novos direitos são garantidos (notadamente os direitos sociais como saúde e educação, e, mais recentemente, os direitos ao meio ambiente equilibrado, ao desenvolvimento econômico, ao patrimônio público da humanidade, etc. ${ }^{54}$ ) os deveres de atuação estatal interventiva crescem igualmente. Não garantir tais direitos em alguma medida ensejaria a responsabilização do Poder Público. Entretanto, o excesso de intervenção estatal traz também riscos indesejáveis. Embora controláveis basicamente pelo vetor da proporcionalidade (conforme analisaremos com mais vagar adiante), leis ou regulamentos editados com a melhor das intenções podem facilmente se tornar intrusões inadmissíveis na autonomia das pessoas, fazendo com que muitas das escolhas legítimas dos indivíduos sejam substituídas por determinações estatais.

Para além do embate liberalismo vs. intervencionismo, é fácil verificar que o cotidiano está cheio de exemplos desse tipo. Certamente o ramo mais fértil de intervenções intrusivas e débeis reside no setor de saúde e alimentação saudável, fruto da ação da chamada milícia alimentar ${ }^{55}$. Nesse sentido, a recente Lei $\mathrm{n}^{\circ} 14.677 / 11$ do Estado de São Paulo estabeleceu que "[a]s redes de estabelecimentos que fornecem refeições no sistema de 'fast food' ficam obrigadas a informar aos consumidores a quantidade de carboidratos, proteínas, gorduras e sódio, bem como o valor calórico contido nos alimentos comercializados" (art. $1^{\circ}$ ), sob pena de aplicação de multa de até 400 UFESPS (art. $2^{\circ}$ ).

\footnotetext{
${ }^{54}$ Para uma visão completa dos direitos fundamentais e sua evolução em gerações ver BONAVIDES, Paulo, Curso de Direito Constitucional, 23ª ed., São Paulo: Malheiros Editores, 2008, páginas 560-578.

${ }^{55}$ O termo é mencionado por David HARSANYI, O Estado Babá, Rio de Janeiro: Litteris, 2011, página 17. Entretanto, o próprio autor prefere chama-los de "Twinkie Fascists".
} 
Pois se o alvo do Governo do Estado de São Paulo foram os estabelecimentos intitulados de "fast food", tramita da Câmara dos Deputados o PL n ${ }^{\circ}$ 505/2011 que prevê a mesma obrigação para quaisquer "[b]ares, restaurantes, lanchonetes e similares" (art. $1^{\circ}$ ). Em sua justificativa, o Deputado Antônio Carlos Mendes de Thame, autor do projeto, salienta que a obesidade e o diabetes, com incidência crescente na população brasileira:

"[E]stão fortemente relacionados a uma alimentação inadequada, especialmente em função da falta de informação qualitativa sobre os alimentos consumidos e à desatenção generalizada quanto à ingestão de calorias em excesso e ao consumo desregrado de substâncias presentes nos alimentos em altos níveis e por isso capazes de aportar malefícios à saúde, como o excesso de sódio, de açúcar, os nitratos e substâncias conservantes e colorantes".

Outro exemplo vem do Ministério do Trabalho e Emprego - MTE no âmbito da regulamentação do Programa de Alimentação do Trabalhador - PAT, instituído pela Lei Federal $n^{\circ}$ 6.321/76 e regulado pelo Decreto $n^{\circ} 5 / 91$. Pois nos termos da Portaria $\mathrm{n}^{\circ}$ 3/02 do MTE, todos os estabelecimentos credenciados e aptos a receber os vale-refeição e vale-alimentação dos trabalhadores devem apenas oferecer comidas saudáveis, com limites específicos de total de calorias, carboidratos, proteínas, gorduras, fibras, sódio, devendo contar ainda com ao menos uma porção de frutas e uma porção de legumes ou verduras (art. $5^{\circ}$ ). Quer dizer, aos trabalhadores das empresas inscritas no PAT (que em dezembro de 2012 montavam o impressionante número de $16.012 .850^{56}$ ) não haveria mais a opção de adquirir comida de baixa qualidade nutritiva, mesmo que legitimamente os indivíduos queiram ingerir alimentos com alto teor de gordura e açúcares, o que acaba transformando a ideia de um Estado garantidor de opções saudáveis na imposição estatal que o cidadão obrigatoriamente coma bem.

Mas não é só. Em termos de educação infantil, tramita na Câmara dos Deputados o Projeto de Lei $\mathrm{n}^{\circ} 7.672 / 10$, que objetiva alterar o Estatuto da Criança e do Adolescente para estabelecer que "[a] criança e o adolescente têm o direito de serem educados e cuidados pelos pais, pelos integrantes da família ampliada, pelos responsáveis ou por qualquer pessoa encarregada de cuidar, tratar, educar ou vigiar, sem o uso de castigo corporal ou de tratamento cruel ou degradante, como formas de

\footnotetext{
${ }^{56}$ Informação disponível em: http://portal.mte.gov.br/pat/relatorios-do-pat.htm.
} 
correção, disciplina, educação, ou qualquer outro pretexto" (art. $1^{\circ}$ ). Nesse sentido, qualquer "ação de natureza disciplinar ou punitiva com o uso da força física que resulte em dor ou lesão à criança" sujeitará seus executores a sanções estatais previstas no Estatuto $^{57}$. E o reiterado descumprimento poderá levar ainda à imposição de medida cautelar determinando o afastamento do agressor da moradia comum da criança, nos termos do artigo 130 da Lei $n^{\circ} 8.069 / 90\left(\right.$ art. $2^{\circ}$ ). Ao que nos parece, portanto, a valer a sistemática adotada pelo PL, qualquer uso de força com intenção disciplinar pode sujeitar os pais, parentes ou responsáveis de uma criança a sanções estatais.

Incidindo de forma indireta sobre relações familiares, a Anvisa vem desde 2002 realizando forte campanha contra o uso de mamadeiras e a favor da amamentação materna das crianças. Nesse sentido, editou a Resolução RDC $\mathrm{n}^{\circ}$ 221/2002 regulamentando o uso e comercialização de chupetas, bicos, mamadeiras e protetores de mamilo. Entre os dispositivos mais críticos, exige o órgão que constem dos rótulos desses produtos frases de efeito como "[a] criança que mama no peito não necessita de mamadeira, bico ou chupeta", "[o] uso de mamadeira, bico ou chupeta prejudica a amamentação e seu uso prolongado, prejudica a dentição e a fala da criança", bem como "[o] uso de protetor de mamilo prejudica a amamentação". Posteriormente, a Lei $\mathrm{n}^{\circ} 11.265 / 06$ não só reafirmou todas essa regras mas também as ampliou. Entre outras coisas, vedou-se completamente a promoção comercial de alimentos substitutos do leite materno e de bicos de sucção (at. $4^{\circ}$ ), bem como restringiu fortemente a exploração comercial dos demais produtos, basicamente evitando associalos a qualquer imagem de vantagem ou de segurança (arts. 10, 11, 13, 14, 15 e 16).

Mas há ainda na Câmara dos Deputados o Projeto de Lei n ${ }^{\circ}$ 4.524/09, que busca proibir completamente "a comercialização de tocadores pessoais de música em formato digital cujo volume sonoro máximo ultrapasse o limite de 90 decibéis", muito embora a Lei ${ }^{\circ} 11.291 / 06$ já obrigue a inserção de advertência nestes produtos indicando os riscos de danos no sistema auditivo por conta da exposição de ruídos com potência superior a 85 decibéis. Assim, para além de conscientizar os indivíduos sobre

\footnotetext{
${ }^{57}$ Nesse sentido, o exercício de tais atos que provoquem dor física à crianças e adolescentes mesmo com caráter de educação familiar ensejará seus executores às seguintes medidas, devidamente previstas no artigo 129 da Lei no 8.069/90: "I - encaminhamento a programa oficial ou comunitário de proteção à família; (...) III - encaminhamento a tratamento psicológico ou psiquiátrico; IV - encaminhamento a cursos ou programas de orientação; VI - obrigação de encaminhar a criança ou adolescente a tratamento especializado; VII - advertência".
} 
os riscos, pretende-se também decidir em nome da coletividade e proibir definitivamente a comercialização de tais equipamentos.

É também digno de referência o Projeto de Lei $\mathrm{n}^{\circ} 1.676 / 99$, que tem por objetivo "a promoção, a proteção, a defesa e o uso da língua portuguesa". Entre outros dispositivos, pretende o referido texto que seja obrigatório o uso da língua portuguesa até mesmo para estrangeiros residentes no país há mais de um ano em determinados ambientes socioculturais, como no ensino e na aprendizagem, no trabalho, nas relações jurídicas, nos meios de comunicação de massa, na publicidade de bens, produtos e serviços, etc. Exceção a esta regra (mais parecem favores) são o exercício dos direitos fundamentais de livre manifestação do pensamento e de livre expressão da atividade intelectual, artística, científica e de comunicação (art. $3^{\circ}$ ).

Mas mais impactante é o que pretende o artigo $4^{\circ}$ do texto, segundo o qual "[t]odo e qualquer uso de palavra ou expressão em língua estrangeira, ressalvados os casos excepcionais nesta lei e na sua regulamentação, será considerado lesivo ao patrimônio cultural brasileiro, punível na forma da lei". Não apenas. Se houver palavra equivalente na língua portuguesa restará configurada prática abusiva; se a palavra estrangeira puder induzir alguém a erro se estará diante de prática enganosa; e se a palavra ou expressão em língua estrangeira descaracterizar qualquer elemento da cultura brasileira configurará prática danosa ao patrimônio cultural ${ }^{58}$.

Segundo o autor do PL, a sociedade está a assistir uma verdadeira descaracterização da língua portuguesa, conforme se nota da invasão indiscriminada e desnecessária do que chama de estrangeirismos, como as expressões holding, recall, franchise, coffee-break, self-service. Em sua opinião, isso levaria a constatação de que estamos "na iminência de comprometer, quem sabe até truncar, a comunicação oral e escrita com o nosso homem simples do campo, não atento as palavras e expressões importadas". Daí a alternativa de criar uma lei para "conscientizar a sociedade brasileira sobre um dos valores mais altos da nossa cultura" ${ }^{59}$.

\footnotetext{
${ }^{58}$ De todo modo, independentemente de questionamentos de constitucionalidade, vale mencionar que normas muitíssimo semelhantes a esta foram efetivamente instituídas nos Municípios de Belém (Lei $\mathrm{n}^{\circ}$ 8563/07), Ji-Paraná (Lei n 1303/04), Rio de Janeiro (Lei n 3516/03) e Ribeirão Preto (Lei n 9196/01).

${ }^{59}$ Para uma visão crítica da pretensão contida no Projeto de Lei ${ }^{\circ} 1.676 / 99$, que ainda tramita no Congresso, ver por todos a obra coletiva de FARACO, Carlos Alberto (org.), Estrangeirismos: guerras em torno da língua, São Paulo: Parábola, 2001. Nesse sentido, como anotam Pedro GARCEZ e Ana Maria Stahl ZILLES "será que alguém lembra que LÈDER até bem há pouco foi leader e que BIFE foi
} 
Por fim, há ainda o Projeto de Lei ${ }^{\circ} 7.913 / 2010$, que busca acrescer três parágrafos ao artigo $1^{\circ}$ da Lei $\mathrm{n}^{\circ} 10.753 / 03$, que instituiu a Política Nacional do Livro. A ideia basicamente é impossibilitar que donos de livrarias ou pontos de venda de livros escolham os livros que pretendem comercializar, devendo obrigatoriamente aceitar quaisquer livros que sejam indicados para venda. Caso se neguem, devem comunicar por escrito ao autor e ao editor os motivos, os quais podem recorrer à Câmara Brasileira do Livro ou as Câmaras Estaduais do Livro, que decidirão a respeito. Em outras palavras, pretende o PL desmercantilizar a comercialização de livros com base em seu valor cultural. Segundo a justificativa apresentada pelo autor do projeto, "[é] preciso, portanto, dar a livraria e ao ponto de vendas do livro um caráter público e social, pois não são meras casas comerciais, ou centros de manobras mercantilistas em favor de grupos econômicos, mas locais de transmissão de circulação de ideias e produtos intelectuais de interesse da cultura nacional".

Independentemente do mérito de cada uma dessas medidas (e certamente há aguerridos defensores para cada uma delas), tratam-se todos de exemplos em que o Poder Público cuida de fazer escolhas em nome da sociedade, substituindo a capacidade cognitiva e a ética pessoal dos indivíduos por outras, pensadas, discutidas e decididas por pessoas que se presumem muito mais capacitadas, vale dizer, a burocracia estatal. E por óbvio, todas essas escolhas são feitas em nome do bem comum, um valor superior, no resguardo de determinado direito e fundadas no interesse público, o que garante o discurso da legitimidade.

De nossa parte, o que há nesses casos é um intervencionismo desmedido que resulta na chamada infantilização da sociedade, em que os indivíduos são tratados como elementos impotentes no aguardo da condução do Estado. Trata-se, pois, de um modo de conduzir a coisa pública maculado por um paternalismo ${ }^{60}$ estatal

beaf? Seriam esses empréstimos intrinsecamente menos impuros do que shopping ou home page? No português, língua de tantas invasões em cinco continentes, invadida e invasora, o que seria puro?" (Estrangeirismos de desejos e ameaças, in Estrangeirismos, op. cit., página 20). E nesse sentido vem a conclusão de Sírio POSSENTI: "Gostaria que o projeto produzisse como efeito a descoberta do óbvio: que, para proteger de fato nossa língua, temos que tornar nossa economia poderosa e nossa cultura tão charmosa que nenhuma outra nos tente." (A questão dos estrangeirismos, in Estrangeirismos, op. cit., página 168)

${ }^{60}$ Como observa Macario ALEMANY, "[t] odas las propuestas conceptuales en torno al paternalismo tienen como mínimo común denominador la que podríamos denominar 'analogía paternalista', es decir, una semejanza de relaciones en la que el foro de la analogía lo constituye la bien conocida relación paterno-filial y el tema lo constituye la relación soberano-súbdito, patrón-obrero, médico-paciente, etc." Nesse sentido, segundo o mesmo autor, "[e]l paternalismo se diferenciaría de la conducta meramente 
que efetivamente desrespeita a autonomia dos indivíduos, uma vez que evita que as pessoas tenham a oportunidade de exercer sua capacidade de eleição de coisas elementares do cotidiano $^{61}$, como a comida que ingerirão, a forma como alimentarão e criarão seus filhos, a linguagem que será utilizada, etc. Fundamentar tais medidas em um bem maior não deixa de ser um mote altamente fluído e perigoso: a depender das preferências do burocrata de plantão, qualquer coisa pode ser considerada indesejável e vedada ao acesso social.

A filosofia e a teoria do direito efetivamente se debruçaram sobre o tema. Ronald DWORKIN estudou as bases do chamado paternalismo, chegando à conclusão que para ser legítimo o paternalismo deve contar com endosso genuíno de seus destinatários, "caso contrário, o paternalismo crítico sempre se justifica acrescentando lavagem cerebral química ou elétrica ao seu regime". E o mesmo autor ressalta a necessidade de haver condições aceitáveis de endosso (notadamente quando ainda há capacidade cognitiva do agente em reconhecer a melhora), bem como o fato de as ameaças de sancionamento provocarem o corrompimento do juízo crítico, já que tira o aspecto genuíno do endosso. Em outras palavras, entende DWORKIN que os limites da intervenção estatal, do ponto de vista moral, residem na justificativa do reconhecimento da sociedade de melhora da qualidade de vida, e ainda assim, esse endosso deve ser aceitável e não decorrente de sancionamento ${ }^{62}$.

Mas e se não houver endosso? É o próprio Ronald DWORKIN que responde dizendo que caso não haja aceitação, o paternalismo deve possuir prazo suficientemente curto e limitado, de modo a não restringir as escolhas dos indivíduos de maneira significativa. Portanto, quer nos parecer que em qualquer caso, mesmo para autores que não negam o paternalismo como uma forma admissível de condução da vida

benevolente porque consiste, según los autores, en coaccionar, interferir con la libertad, faltar al respeto debido, violar la autonomía, engañar, ocultar información, violar normas morales, etc". (El concepto y la justificación del paternalismo, in DOXA, Cuadernos de Filosofia del Derecho, $\mathrm{n}^{\circ}$ 28, Alicante: Universidad de Alicante, 2005, páginas 566-167 e 268)

${ }^{61}$ Cf. HUSAK, Douglas, Paternalism and Autonomy, in Philosophy \& Public Affairs, vol. 10, Hoboken: Wiley, 1981, páginas 34-37.

${ }^{62}$ A Virtude Soberana, São Paulo: Martins Fontes, 2005, páginas 299-302. 
em sociedade, a limitação às escolhas individuais é um elemento importante e faz a diferença $^{63}$.

E esse ponto é importante até mesmo para autores desenvolvimentistas. Note-se que a teoria da igualdade como desenvolvimento de Amartya SEN, embora se valha da maximização das capacidades intelectuais e sociais dos indivíduos para fruírem adequadamente de sua liberdade individual, não retira logicamente a importância da autonomia individual sobre as escolhas cotidianas, sob pena de cometer uma tautologia: restrições à liberdade individual seriam toleradas em busca de uma liberdade igualitária até o ponto em que, alcançada esta última, diversas escolhas individuais seriam vedadas a todos. Segundo SEN:

"O êxito de uma sociedade deve ser avaliado, nesta visão, primordialmente segundo as liberdades substantivas que os membros dessa sociedade desfrutam. Essa posição avaliatória difere do enfoque informacional de abordagens normativas mais tradicionais, que se concentram em outras variáveis, como utilidade, liberdade processual ou renda real. (...) Ter mais liberdade para fazer as coisas que são justamente valorizadas é (1) importante por si mesmo para a liberdade global da pessoa e (2) importante porque favorece a oportunidade de a pessoa ter resultados valiosos.6 ambas as coisas são relevantes para a avaliação da liberdade

\footnotetext{
${ }^{63}$ Cf. A Virtude Soberana, op. cit., página 376. Entretanto, a tese do endosso legítimo não é logicamente unânime e possui suas falhas. Para Gerald DWORKIN, a relação entre o que chama de "legal paternalism" (LP) e "moral paternalism" (MP) com base no próprio reconhecimento de Ronald Dworkin sobre as limitações do argumento do endosso genuíno, aponta o seguinte: "Uma premissa essencial no argumento justificativo para a MP é que é possível melhorar o bem estar moral da pessoa impondo mudanças nas quais a pessoa não endossa. Vimos, no entanto, que mesmo aceitando o endosso (Dworking) ou baseado na visão (Feinberg) de bem pessoal, há considerável margem para tais mudanças, i.e. as conexões irreconhecíveis com valores que a pessoa não endossa. E se a visão em si é correta não foi demonstrado. Finalmente, deve-se notar que mesmo se a tese do endosso fosse correta, $e$ a verdade sobre essa visão coloca limitações nos tipos de MP que estejam sendo justificadas, ainda restaria a seguinte possibilidade. O fato de várias mudanças serem boas, ainda que não boas para a pessoa, abre espaço para um novo princípio limitativo da liberdade. Temos o direito de interferir com pessoas que não melhoram sua qualidade de vida para simplesmente fazê-las melhores em termos morais. Pois nada nos argumentos acima mostra que as mudanças propostas não melhoram a vida da pessoa, ou fazem sua vida moralmente melhor. Se, por exemplo, a vida de uma prostituta é moralmente degradante, então proibindo a pessoa de se envolver nessa ocupação acaba prevenindo-a de levar uma vida degradante. Nossa justificativa para certos tipos de interferência então não levaria em conta pela preocupação com o bem estar da pessoa, mas por respeito a ela como pessoa. Forçando um viciado em drogas a se livrar do vício pode não ser melhor para ele na suposição de que ele prefere sua vida como viciado a uma nova, mas poderia ser justificada no fato de que sua nova vida é melhor em qualquer caso" (Moral Paternalism, in Law and Philosophy, vol. 24, $\mathrm{n}^{\circ}$ 3: Springer Netherlands, mai/2005, páginas 318-319 - tradução livre).
} 
dos membros da sociedade e, portanto, cruciais para a avaliação do desenvolvimento da sociedade." ${ }^{64}$

Portanto, o que se quer aqui afirmar são os riscos de não se admitir ou mesmo perquirir limites à intervenção estatal social e econômica, imaginando que tudo depende das vontades e preferências dos administradores de ocasião. Do ponto de vista jurídico, conforme se verá adiante, excessos podem ser coibidos pelo vetor da proporcionalidade. Entretanto, a intervenção excessiva faz o Estado se entronizar contundentemente na autonomia privada dos indivíduos, negando o direito de cada um de determinar o próprio comportamento individual, o que resulta em um processo de infantilização da sociedade. Pois nem mesmo pautas alegadamente de interesse público e promessas de um futuro melhor legitimam restrições que negam escolhas básicas das pessoas em temas cotidianos e lhe tolhem o direito de conduzir suas próprias vidas de acordo com suas cognições pessoais.

Nesse sentido, Marçal JUSTEN FILHO traz uma arguta observação a propósito de apresentar suas concepções ideológicas a respeito da intervenção estatal na liberdade dos indivíduos (partindo do pressuposto de distinguir em seu texto o que é ciência jurídica - abstrata por natureza - e o que se insere no conceito de convicções político-ideológicas pessoais). Segundo o autor:

"A ampliação das funções do Estado equivale à redução da liberdade e da autonomia pessoal. Mas a imposição de limites às competências estatais não pode propiciar o retrocesso a uma espécie de 'estado de natureza', em que o homem seja lobo do homem.

Nesses dias, em que se afirma a redução das dimensões do Estado, a sociedade se depara com um impasse. A atribuição de incontáveis funções à estrutura estatal produzia não apenas a redução da autonomia privada, mas também da responsabilidade moral do indivíduo. É que a visão ampliativa das funções do Estado gerava concepções paternalistas que desoneravam os indivíduos. Significava a irrelevância da participação do particular para promover o princípio da dignidade da pessoa humana e os demais valores fundamentais. Aludir a solidariedade humana tornou-se quase despropositado, em fase da ilusão de que algum órgão estatal se encarregaria de atender às necessidades alheias. Sob um certo ângulo, a afirmação de um Estado de Bem Estar trazia consigo uma grande comodidade filosófica: a transplantação da responsabilidade social do indivíduo para o Estado. (...)

\footnotetext{
${ }^{64}$ Desenvolvimento como Liberdade, São Paulo: Companhia das Letras, 2007, páginas 32-34.
} 
A realidade evidenciou a falsidade da doce ilusão de que a supressão da autonomia individual resultaria na eliminação da pobreza e das desigualdades regionais. A revolução capaz de mudar o panorama de nossa realidade não se faz apenas ou preponderantemente em nível estatal, mas depende da participação ativa dos indivíduos e das organizações não estatais." 65

De nossa parte, embora concordemos integralmente com suas conclusões, temos algum receio de tratar os limites da intervenção estatal como inseridos em alguma concepção ideológica a respeito do protagonismo do Poder Público. Afinal, conforme também se discutirá adiante, se algum valor possuem os dispositivos constitucionais que tratam de justiça social, do desenvolvimento nacional e da erradicação das desigualdades, há também algum significado nas diversas passagens que garantem ao cidadão brasileiro o direito de conduzir sua vida com o mínimo de autonomia. Não que se pretenda com isso afirmar que a Constituição prega um maior ou menor intervencionismo estatal, mas sim que resguarda certamente a autonomia dos indivíduos como um valor fundamental do Estado brasileiro, garantindo, como anota o próprio autor, que os valores fundamentais da sociedade sejam buscados através do Estado, da sociedade civil e do cidadão ${ }^{66}$.

Daí a querer nos parecer que perquirir limites à intervenção estatal se fundamenta mais em respeitar a pluralidade de opções contidas na Constituição Federal do que apresentar concepções pessoais sobre qual seria o nível ótimo de intervenção. E como será apresentado mais adiante no texto, a subsidiariedade como limite interventivo garante espaço à toda a sorte de opções político-legislativas a respeito do tema.

\footnotetext{
${ }^{65}$ O Direito das Agências Reguladoras Independentes, São Paulo: Dialética, 2002, páginas 11-12.

${ }^{66}$ Cf. JUSTEN FILHO, Marçal, O Direito das Agências Reguladoras Independentes, op. cit., página 11.
} 


\section{CAPÍTULO 2. REGULAÇÃO ECONÔMICA: CONCEITUAÇÃO, FUNDAMENTOS E PRINCIPAIS CARACTERÍSTICAS}

\section{II.1. Conceito amplo de regulação}

Voltemos, entretanto, ao tema da intervenção estatal na ordem econômica, notadamente a que se refere à regulação econômica.

Com efeito, a atividade de intervenção regulatória do Estado na economia nada tem de novidade. Trata-se, em verdade, de mecanismo dos mais tradicionais de intervenção do Estado no domínio econômico. No Brasil, como ensina Themístocles Brandão CAVALCANTI, desde a Constituição de 1891 já se reconhecia a competência do Estado para regular a economia ${ }^{67}$. Em verdade, segundo Dinorá Adeilaide Musetti GROTTI, no Brasil, "[d]e longa data existe uma série de órgãos e entidades reguladoras (...), tais como o Comissariado de Alimentação Pública (1918), o Instituto de Defesa Permanente do Café - IBC (1923), o Instituto do Álcool e do Açúcar - IAA (1933), o Instituto Nacional do Mate (1938), o Instituto Nacional do Sal (1940), o Instituto Nacional do Pinho (1941)"68, etc.

De fato, desde um ponto de vista histórico, a regulação não deixa de ser uma faceta mais evoluída e aderente às necessidades contemporâneas do clássico poder de polícia ${ }^{69}$ administrativa $^{70}$, também chamada de polícia econômica ${ }^{71}$, uma

${ }^{67}$ Tratado de Direito Administrativo, tomo I, $2^{\mathrm{a}}$ ed., Rio de Janeiro: Editora Freitas Bastos, 1948, página 540.

${ }^{68}$ As Agências Reguladoras, in Revista Brasileira de Direito Público - RBDP, ano 2, $\mathrm{n}^{\circ} 4$, Belo Horizonte: Fórum, jan/mar 2004, páginas 190-191.

${ }^{69}$ Segundo aponta Renato ALESSI, "[p]olicía es, en efecto, la actividad administrativa dirigida a tutelar el conjunto social y sus miembros, mediante una actividad de observación, de prevención y represión, contra los daños que podrían derivarse para aquellos de la actividad de los individuos, clasificándose en policía de seguridad y en policía administrativa (ligada esta última a todas las ramas de la Administración), según que tenga por finalidad específica el tutelar el orden público, o la finalidad genérica de tutelar intereses de otra naturaleza, que se refieran a oras ramas de la Administración: por ejemplo, intereses sanitarios (policía sanitaria), protección de los bienes dominiales (policía de los bienes dominiales), interés ético (policía de costumbres), etc." (Instituciones de Derecho Administrativo, tomo II, Barcelona: Bosch, 1970, páginas 468-469)

${ }^{70}$ Daí o sentido de Themistolces Brandão CAVALCANTI dizer que "[a] técnica do poder de polícia se especializa na ação normativa e na prática de atos administrativos em que a ação discricionária é mais intensa, quando cogita de encontrar formas de equilíbrio, na apreciação da conveniência e oportunidade dos atos sujeitos a ação administrativa. (...) Eis porque, no terreno econômico, a ação do Estado consiste, no exercício do poder de polícia, na atividade normativa, regulamentar, e na aplicação de 
espécie de categoria especial da atividade. Contudo, não se tratam de conceitos coincidentes $^{72}$. Desde há muito a doutrina percebeu as dificuldades de se tratar as intervenções mais modernas no domínio econômico como simples exercícios do poder de polícia. Na doutrina espanhola, essa é a opinião de Joaquín TORNOS MAS:

"A partir, pois, desta concepção da atividade da Administração como ordenadora do mercado se supera a visão que tratava de reduzir todo o processo de atuação administrativa na economia a um processo dialético autoridade-liberdade. (...) Quero dizer com isso que no curso da determinação de preços se produz uma autêntica ordenação geral do mercado, que afeta de forma indiscriminada e, evidentemente, com conteúdos muito diversos, a pluralidade de administrados e aos diferentes interesses particulares ou coletivos que estes possam encarnar. Por isso, continuar falando destes tipos de intervenções como dentro de um velho conceito de policia é bastante mistificador." ${ }^{33}$

Entre nós, Carlos Ari SUNDFELD, por exemplo, questionava desde 1993 se fazia algum sentido incluir na concepção de poder de polícia (elástica por natureza) atividades como a intervenção em instituições financeiras, imposição do dever de vender produtos de primeira necessidade, tabelamento de preços ${ }^{74}$, ou seja, atividades típicas de regulação econômica. No mesmo sentido, Calixto SALOMÃO FILHO apontou com precisão a debilidade do mecanismo de polícia administrativa para dar conta de transformar os atores privados de meros figurantes a verdadeiros

sanções e medidas coercitivas." (Curso de Direito Administrativo, $6^{\mathrm{a}}$ ed., Rio de Janeiro: Editora Freitas Bastos, 1961, página 190) Para uma análise evolutiva da adaptação das teorias tradicionais do poder de polícia às atividades interventivas na economia ver PALASÍ, José Luis Villar, Poder de Policía y Precio Justo. El Problema de la Tasa de Mercado, in Revista de Administración Pública, nº 16, Madrid: Centro de Estudios Políticos y Constitucionales, jan/abr 1955, páginas 11-83.

${ }^{71}$ Cf. DROMI, Roberto, Derecho Administrativo, $11^{\text {a }}$ ed., Buenos Aires: Ciudad Argentina: 2006, página 926. Como anota Cabral de MONCADA, "[a] intervenção unilateral na actividade económica, ainda hoje majoritária, como já se disse, é normalmente tributária de uma concepção policial da intervenção económica os poderes públicos. As intervenções de polícia económica, tipicamente unilaterais, produzem-se se e quando a perigosidade social e económica de uma determinada actividade as reclamam, como meio de garantir a ordem e a segurança." (Direito Económico, op. cit., página 40)

${ }^{72}$ Gaspar Ariño ORTIZ tratou logo de diferenciar ambos os conceitos. Para ele, a polícia administrativa ou regulação externa é a atividade normativa em que o Governo condiciona, corrige, altera os parâmetros naturais e espontâneos do mercado, mas o faz de fora da atividade, por meio basicamente de legislação trabalhista, industrial, ambiental, econômica, etc. Já a regulação econômica se centra fundamentalmente na entrada e saída da atividade e afeta aos seus condicionantes econômicos, como a produção, abrangência mercadológica, preços, etc. (Estado y Economia, Buenos Aires: Abeledo-Perrot, 1993, páginas 42-43)

${ }^{73}$ La Ordenación Administrativa de los Precios Privado, in Revista de Administración Pública, $\mathrm{n}^{\circ} 85$, Madrid: Centro de Estudios Políticos y Constitucionales, mai/ago 1978, páginas 278-279 - tradução livre.

${ }^{74}$ Direito Administrativo Ordenador, São Paulo: Malheiros Editores, 2003, página 15. 
parceiros em relação ao processo de desenvolvimento econômico do Brasil ${ }^{75}$. De fato, foi justamente a ampliação da complexidade socioeconômica que deu ensejo à busca por mecanismos de intervenção estatal igualmente mais complexos e que não tivessem por objetivo apenas reprimir determinadas atividades. Precisava-se de mais, era necessário se valer de mecanismos que restringissem, mas que também induzissem e estimulassem os atores privados a realizar condutas social e economicamente consideradas indispensáveis ou ao menos desejáveis ${ }^{76}$.

Surge aí o contexto da regulação como instrumento de direito administrativo.

Regulação, entretanto, é termo de múltiplos significados. Do ponto de vista etimológico, qualquer ordenação administrativa implica em uma regulação da conduta social, no sentido de vinculação jurídica e mandatória direcionada aos particulares $^{77}$. Não obstante, Jacques CHEVALLIER afirma ser possível extrair três significados que se complementam. Em primeiro lugar há a função reguladora do direito ("fonction régulatrice du droit"), vista, sob uma perspectiva externa, como um meio de controle comportamental da sociedade e, internamente, como um sistema coeso e que inadmite perturbações exteriores. Em segundo lugar, há o que chama de direito regulador ("droit régulateur"), que é uma característica particular de um tipo específico de organização estatal (o Estado Providência), em que a condução dos indivíduos em sociedade se dá pela instituição de prescrições ou injunções que tem por objetivo ditar o comportamento de forma positiva, de modo a possibilitar um efetivo controle e normatização tendente à regulação da sociedade ${ }^{78}$.

Por fim, há ainda o terceiro significado, chamado pelo autor de "droit de régulation", que sintetiza os problemas enfrentados pelas novas sociedades

75 Regulação e Desenvolvimento, in SALOMÃO FILHO, Calixto (coord.), Regulação e Desenvolvimento, São Paulo: Malheiros Editores, 2002, páginas 57-59.

${ }^{76}$ Cf. JUSTEN FILHO, Marçal, Curso de Direito Administrativo, op. cit., página 642.

${ }^{77}$ É esta a acepção dada por Harmut MAURER: "O ato administrativo tem caráter regulativo. Regulação é uma ordenação vinculativa juridicamente, uma declaração de vontade (ou várias declarações de vontade ajustadas mutuamente) que está dirigida para a fixação de uma consequência jurídica. A consequência jurídica consiste nisto, que direitos elou deveres são fundamentados, modificados, anulados ou determinados vinculativamente ou que, enquanto se reconhece atos administrativos reais (...), o estado jurídico de uma matéria é determinada." (Direito Administrativo Geral, 14a ed., Barueri: Manole, 2005, páginas 207-208)

${ }^{78}$ La Régulation Juridique en Question, in Droit et Societé, n 49, Paris: LGDJ, 2001, páginas 830-833. 
contemporâneas (desafiadas pelo que entende ser o fenômeno da globalização). Segundo aponta, o direito da regulação se apresenta como expressão do direito pósmoderno, marcado pelo pragmatismo e pela flexibilidade. Pragmatismo por conta da associação dos destinatários ao processo de elaboração de suas normas, as quais são feitas pelo confronto e arbitragem de interesses sociais que se pretende harmonizar, resultando em um direito negociado, fruto da deliberação coletiva. Daí o sentido de se utilizar técnicas jurídicas mais flexíveis e menos autoritárias, justamente por demandar aperfeiçoamento constante das normas editadas ${ }^{79}$. E é aplicando este último conceito ao sistema de intervenção estatal na economia que Jacques CHEVALLIER, em outra obra, ensina o seguinte:

"A regulação se distingue dos modos clássicos de intervenção do Estado na economia: ela consiste em supervisionar o jogo econômico, estabelecendo certas regras e intervindo de maneira permanente para amortecer as tensões, compor os conflitos, assegurar a manutenção de um equilíbrio do conjunto; pela regulação, o Estado não se põe mais como ator mas como árbitro do processo econômico, limitando-se a enquadrar a atuação dos operadores e se esforçando para harmonizar as suas ações. A implantação dessa função pressupõe a reunião de diversas condições: uma posição de exterioridade relativamente ao jogo econômico; uma capacidade de arbitragem entre os interesses em jogo; uma ação contínua a fim de proceder aos ajustes necessários. (...) O novo papel desempenhado pelo Estado na economia não se reduz, no entanto, a uma simples função de regulação: ele se traduz também por uma intervenção ativa no jogo econômico, tomando em conta o contexto de interdependência ligado ao processo de globalização. ${ }^{180}$

De fato, a regulação econômica se traduz em intervenções diretas ou indiretas do Poder Público sobre o domínio econômico congregando diversas funções estatais, tendo todas por finalidade conformar e de alguma forma conduzir os atores privados ao atingimento de determinado fim de interesse público. Nesse sentido, parece acertado definir a regulação em um sentido amplo como faz Floriano de Azevedo MARQUES NETO, segundo o qual se trata de "atividade estatal mediante a qual o Estado, por meio de intervenção direta ou indireta, condiciona, restringe, normatiza ou incentiva a atividade econômica de modo a preservar a sua existência, assegurar o seu

\footnotetext{
${ }^{79}$ La Régulation Juridique en Question, op. cit., páginas 833-834.

${ }^{80}$ O Estado Pós-Moderno, Belo Horizonte: Fórum, 2009, pagina 73.
} 
equilíbrio interno ou atingir determinados objetivos públicos como a proteção de hipossuficiências ou a consagração de políticas públicas" ${ }^{\sharp 1}$.

\section{II.2. Fundamentos jurídicos e características da regulação econômica no Brasil}

Conforme visto, a regulação estatal configura uma espécie do gênero atividade administrativa, tratando-se de um mecanismo de intervenção do Estado no domínio econômico. No Brasil, é exercida pelo Poder Público com base no artigo 174 da Constituição, que diz que, "[c]omo agente normativo e regulador da atividade econômica, o Estado exercerá, na forma da lei, as funções de fiscalização, incentivo $e$ planejamento, sendo este determinante para o setor público e indicativo para o setor privado".

Logo, tanto a própria Constituição (nos casos por ela especificados) quanto a legislação ordinária poderão determinar os campos onde terá lugar a regulação estatal, podendo ir de serviços públicos (telecomunicações, energia, transportes), a uso de bens públicos relevantes (petróleo, recursos hídricos, portos), atividades que envolvam riscos de colapso sistêmico (setor financeiro, mercado de seguros) ou também sobre atividades consideradas como de interesse geral (tais como a saúde suplementar e a vigilância sanitária) ${ }^{82}$.

E justamente por se tratar de uma função pública ${ }^{83}$, pode a regulação ser desempenhada tanto por entes estatais com competência específica e características especiais (como por exemplo as agências reguladoras), como por órgãos tradicionais da Administração Pública brasileira, que, embora possuam competência normativa, não detém algumas prerrogativas comumente caracterizadas como essenciais para uma regulação efetivamente independente. Em verdade, existem no Brasil diversos órgãos administrativos reguladores que nunca foram classificados como agências, como o Banco Central, a Comissão de Valores Mobiliários - CVM, o Conselho Monetário

\footnotetext{
${ }^{81}$ A Nova Regulação dos Serviços Públicos, in Revista de Direito Administrativo - RDA, vol. 228, Rio de Janeiro: Renovar, 2002, página 14. No mesmo sentido, ver ARAGÃO, Alexandre Santos, Agências Reguladoras, $2^{\text {a }}$ ed., Rio de Janeiro: Forense, 2006, página 37.

${ }^{82}$ Cf. MARQUES NETO, Floriano de Azevedo, Regulação Econômica e suas Modulações, in Revista de Direito Público da Economia - RDPE, ano 7, n² 28, Belo Horizonte: Fórum, out/dez 2009, página 36.

${ }^{83}$ Cf. SOUTO, Marcos Juruena Villela, Direito Administrativo Regulatório, $2^{\text {a }}$ ed., Rio de Janeiro, Lumen Juris, 2005, página 40.
} 
Nacional - CMN, o Conselho Nacional de Educação - CNE, o Conselho Nacional de Trânsito - CONTRAN, os Ministérios federais, etc ${ }^{84}$. De todo modo, inegável que foi a partir do fenômeno da agencificação ${ }^{85}$ ocorrido no Brasil em meados dos anos 90 do século passado é que surgiram as maiores reflexões acerca da regulação econômica, seja no que respeita à competência normativa das agências, à sua adequação ao sistema de tripartição de poderes, à sua legitimidade decisória em face do vetor democrático, etc.

Outra classificação importante relativa a abrangência da atividade regulatória do Estado envolve os interesses a serem preservados. É comum nesse sentido dizer que configura regulação aquela desenvolvida por mecanismos estatais de defesa dos interesses difusos e hipossuficientes, tal qual a realizada pelo Sistema Brasileiro de Defesa do Consumidor (Decreto Federal $n^{\circ}$ 2.181/97) e com o próprio CADE acima mencionado, que cuida da defesa da concorrência. Daí ser possível falar, como faz Floriano de Azevedo MARQUES NETO, na existência de uma regulação setorial - relativa a um setor ou segmento da economia - e de uma outra regulação tida como transversal, que perpassa diversos setores econômicos tendo como mote a tutela de interesses gerais tidos como essenciais à sociedade (consumidor e antitruste) ${ }^{86}$.

De todo modo, em função da dicção constitucional contida no artigo 174 outra nota importante emerge a respeito da regulação econômica. Refere-se aqui à distinção entre os vocábulos regulação e regulamentação. Nesse sentido, costuma-se discutir na doutrina se se tratariam de termos coincidentes ou não. É certo que há opiniões para todos os gostos, entretanto, tendo em vista que a própria Constituição

${ }^{84}$ DI PIETRO, Maria Sylvia, Limites da Função Reguladora das Agências diante do Princípio da Legalidade, in DI PIETRO, Maria Sylvia (org.), Direito Regulatório: temas polêmicos, $2^{\mathrm{a}}$ ed., Belo Horizonte: Fórum, 2009, página 28.

${ }^{85}$ Cf. SANTOS, Luiz Alberto, Agencificação, Publicização, Contratualização e Controle Social: Possibilidades no âmbito da Reforma do Aparelho do Estado, Brasília: DIAP, 2000; DI PIETRO, Maria Sylvia Zanella, O direito administrativo brasileiro sob influência dos sistemas de base romanística e da common law, in Revista Brasileira de Direito Público - RBDP, ano 5, $\mathrm{n}^{\circ}$ 16, Belo Horizonte: Fórum, jan/mar 2007, páginas 9-30. A bem da verdade, o termo agencificação foi cunhado do inglês agencification, que traduz um mecanismo comum do processo de reforma da gestão publica, confeccionado basicamente pela criação de uma governança distribuída em órgãos politica e financeiramente independentes do governo central. Para uma análise aprofundada do tema ver POLLITT, Christopher e TALBOT, Colin (orgs.), Unbundled Government: a critical analysis of the global trend to agencies, quangos and contractualization, Londres: Routledge, 2004, em especial o artigo de TALBOT, The Agency idea: sometimes old, sometimes new, sometimes borrowed, sometimes untrue, páginas 1-21.

${ }^{86}$ Regulação Setorial e Autoridade Antitruste: A Importância da Independência do Regulador, in CAMPLILONGO, Celso Fernandes et. al. (coords.), Concorrência e Regulação no Sistema Financeiro, São Paulo: Max Limonad, 2002, páginas 93-107. 
segrega a atividade normativa (regulamentar) da atividade regulatória, parece óbvio ser defeso ao interprete tratá-las como sinônimas ${ }^{87}$. Nesse contexto, a função regulatória é conceito bastante mais amplo que a regulamentar, e compreende, como ensina a doutrina, um híbrido de atribuições de variada natureza, tais como informativas, planejadoras, fiscalizadoras, conciliadoras, normativas, arbitradoras e sancionatórias ${ }^{88}$.

E é justamente por conta disso que se afirma que toda esta gama de diferentes atividades deve contar com base legal, a qual tem como escopo principal definir as competências e objetivos gerais a serem perseguidos pelo regulador (o que é chamado pela doutrina de lei-quadro ${ }^{89}$ ou estandardizada) ${ }^{90}$. Ocorre, entretanto, que a atividade regulatória estatal não se subsume à definição legal, mas sim a inova. Em outras palavras, e este certamente configura uma das principais características da atividade regulatória, embora tenha como elo de legitimidade as competências e atribuições previamente definidas em lei, a regulação estatal da economia não se resume a um mecanismo de mera subsunção. Tem, por outro lado, como finalidade elementar justamente inovar o ordenamento jurídico criando normas regulatórias abstratas que condicionam ou incentivam os agentes privados. Ou seja, é da essência da atividade regulatória que haja inovação, acréscimo de normas, criação de novos direitos e deveres aos agentes privados.

${ }^{87}$ Cf. MARQUES NETO, Floriano de Azevedo, Agências Reguladoras Independentes: Fundamentos e seu Regime Jurídico, Belo Horizonte: Fórum, 2005, páginas 37-38. Em sentido semelhante, ver ALMEIDA, Fernando Dias Menezes de, Teoria da Regulação, in CARDOZO, José Eduardo Martins et. al. (orgs), Curso de Direito Administrativo Econômico, vol. III, São Paulo: Malheiros Editores, 2006, páginas 130-132.

${ }^{88}$ MOREIRA NETO, Diogo de Figueiredo, Direito Regulatório, op. cit., página 107.

${ }^{89}$ As leis quadro são de origem francesa (lois-cadre), da IV República, basicamente criadas sob o regime da Constituição Francesa de 1946. Como lembra Luís S. Cabral de MONCADA, tratava-se de um sistema em que "o parlamento votava uma lei reduzida aos princípios fundamentais dos regimes jurídicos e em consequência o Governo ficava autorizado a apresentar ao parlamento, dentro de certo prazo, decretos complementares. Não entravam logo em vigor pois que careciam de ratificação parlamentar mas se não fossem rejeitados ou modificados pelo parlamento dentro de certo prazo entravam automaticamente em vigor." (Ensaio sobre a lei, Coimbra: Coimbra Editora, 2002, página 105)

${ }^{90}$ Cf. ARAGÃO, Alexandre Santos de, Princípio da Legalidade e Poder Regulamentar no Estado Contemporâneo, in Revista Trimestral de Direito Público - RTDP, $\mathrm{n}^{\circ}$ 38, São Paulo: Malheiros Editores, 2002, páginas 93-94. Note-se que Paulo OTERO chama as leis-quadro de "normas legais em branco", ou seja, "o fenómeno pelo qual uma norma com valor e força de lei, atendendo à incompletude do conteúdo da sua previsão, remete a respectiva integração, complementação ou determinação para instrumentos jurídicos (normativos ou não normativos) de grau ou nível inferior" (Legalidade e Administração Pública: O Sentido da Vinculação Administrativa à Legalidade, Coimbra: Almedina, 2003, página 895). 
E apesar de este modelo ser bastante criticado, sua configuração se mostra essencial para uma Administração Pública que tem como função arbitrar interesses públicos conflitantes e, ainda assim, atingir as finalidades institucionais dispostas na Constituição. É o que explica Diogo de Figueiredo MOREIRA NETO:

\begin{abstract}
"Esse complexo de funções vai cometido a um único órgão regulador, para que este defina especificamente o interesse que devera prevalecer e ser satisfeito nas relações sujeitas à regulação. (...) Não se trata, portanto, da tradicional aplicação direta de uma definição legal vinculadora de certo interesse público específico, nem, tampouco, e muito menos, de chegar a uma definição legal discricionária, que é a que deve ser integrada pelo administrador por subsunção, à feição da administração tradicional, isso porque o interesse específico que deverá prevalecer nas relações submetidas à função reguladora não estará predeterminado, senão que deverá ser deduzido dos fatos, pelo exercício qualificado, negociado e ponderado dessa função."
\end{abstract}

\title{
II.2.1. Conceito de regulação adotado no trabalho: a regulação administrativa
}

Voltando às nomenclaturas, parece-nos importante mencionar que o conceito de regulação que se utilizará no presente trabalho é um pouco mais restrito que aquele apresentado acima (item II.1). Isso porque, se estamos a defender que há um vetor de subsidiariedade que limita a intervenção regulatória estatal, então esse mecanismo deve ser instrumentalizado. Utilizar um conceito muito amplo de regulação, faria esse critério de subsidiariedade incidir também em um viés legislativo, obrigandonos a tratar do controle de constitucionalidade de leis que regulam atividades econômicas em alguma medida. E embora reconheçamos que a subsidiariedade, por ser decorrente do Texto Constitucional, incide também na regulação estatal de sede legislativa, a diferença dos institutos capazes de tratar de sua aplicação concreta tornariam o escopo do trabalho por demais amplo, com perdas significativas de metodologia. Daí o sentido de delimitar um pouco mais o conceito de regulação que se está analisando.

Partimos, pois, do pressuposto que a atividade regulatória que nos interessa é aquela referente aos condicionamentos e estímulos editados pela

\footnotetext{
${ }^{91}$ Direito Regulatório, op. cit., páginas 107-108.
} 
Administração Pública, não pelo Estado em geral. Trata-se, pois, da regulação administrativa da economia ${ }^{92}$. Isso, portanto, exclui do conceito a atividade legislativa, recaindo apenas na regulação editada por órgãos administrativos. O conceito de regulação extraído do artigo 174, conforme visto acima, abrange mas também extrapola o sentido aqui referido, já que toma como pressuposto a competência regulatória do Estado como um todo. Daí a necessidade de delimitá-lo em alguma medida.

Dito isso, parece-nos coerente definir a regulação administrativa da economia como a parcela da regulação estatal proveniente da Administração Pública ou pela qual esta se responsabiliza, mediante o exercício de função administrativa (regulatória). Cuida-se de parcela da regulação que provém de órgãos e instâncias integradas à Administração Pública, excluindo, portanto, a produzida por outros centros de criação de regulação pública, como o Poder Legislativo ${ }^{93}$.

A regulação administrativa da economia é consubstanciada em um sistema de indução, orientação e de controle dos comportamentos dos agentes econômicos. É também exercida em um viés positivo, na forma de comandos, diretrizes e recomendações, como também em um viés negativo, isto é, mediante proibições, limitações ou advertências. Tem como principais mecanismos a edição de normas regulatórias, o acompanhamento do cumprimento dessas regras, o eventual sancionamento pelo seu descumprimento, assim como a atribuição de habilitações (por exemplo, autorizações, permissões e concessões) e a mediação e composição de conflitos (consultas e audiências públicas, compromissos de cessão de conduta e de ajustamento) ${ }^{94}$. Exprime-se, nesse sentido, através de atos administrativos de caráter normativo, investigatório, sancionatório e conciliatório.

Este o conceito de regulação administrativa da economia que será utilizado como premissa para o presente trabalho.

\footnotetext{
${ }^{92}$ Cf. em sentido semelhante MATTOS, Paulo Todescan Lessa, O Novo Estado Regulador no Brasil, op. cit., página 35 .

${ }^{93}$ Cf. GONÇALVES, Pedro António P. Costa, Regulação Administrativa e Contrato, in Revista de Direito Público da Economia - RDPE, ano 9, n 35, Belo Horizonte: Fórum, jul/set 2011, páginas 107 111.

${ }^{94}$ Cf. MEDAUAR, Odete, O Direito Administrativo em Evolução, $2^{\text {a }}$ ed., São Paulo: Revista dos Tribunais, 2003, página 257.
} 


\section{II.3. Regulação e autorregulação}

Outro tema pertinente ao presente estudo se refere à autorregulação. Se a regulação é um termo prenhe de sentidos desencontrados, a autorregulação disso não se afasta muito, ainda que possua significados inconfundíveis. Com efeito, como o próprio nome indica, a autorregulação representa um processo de normatização privada, que surge a partir do interesse e iniciativa dos próprios atores econômicos envolvidos em determinado setor. Ou seja, enquanto a regulação administrativa é imposta pela autoridade pública sob o pálio da unilateralidade de seus comandos, a autorregulação surge dos próprios entes regulados ${ }^{95}$, que se organizam e autorregulam determinada atividade. Trata-se, pois, de mecanismo de regulação que se estabelece pela adesão e cumprimento consensual de normas e padrões de atuação editados pelos próprios atores econômicos privados $^{96}$.

Por conta disso, suas finalidades são intramercado, ou seja, buscam apenas garantir ou implementar as condições ideais de exploração de determinada atividade à luz da percepção dos próprios agentes. Daí o motivo de não representar um mecanismo ideal para a implantação de políticas públicas sociais ou para coibir externalidades. Isso, entretanto, não torna o mecanismo desimportante. Como ensina José Esteve PARDO, foi justamente em função de alguns efeitos extremamente positivos trazidos pela sistemática da autorregulação que o tema tornou-se em alguma medida importante ou interessante ao debate regulatório, a ponto de ser considerada como referência para as normas regulatórias editadas pelos Poderes Públicos ${ }^{97}$. De todo modo, a questão relativa aos interesses configura o principal diferencial entre a regulação e a autorregulação: a primeira tem como mote combinar o funcionamento adequado dos mercados com pautas de interesse público; a segunda é gerida com base nas aspirações dos próprios agentes econômicos, somente atingindo efeitos positivos reflexamente.

\footnotetext{
${ }^{95}$ Segundo anota José Esteve PARDO, como conceito genérico, a autorregulação configura fenômeno dos mais corriqueiros. Para este autor, "[c]ualquier organización se autorregula de algún modo", seja quando "fija sus pautas de actuación, estabelece sistemas de autocontrol de sus productos o realiza auditorías internas" (Autorregulación: genesis y efectos, Navarra: Editorial Arazandi, 2002, página 15)

${ }^{96}$ Cf. MARQUES NETO, Floriano de Azevedo, Regulação Estatal e Autorregulação na Economia Contemporânea, in Revista de Direito Público da Economia - RDPE, no 33, Belo Horizonte: Fórum, jan/mar 2011, página 90.

${ }^{97}$ Autorregulación, op. cit., página 16.
} 
Floriano de Azevedo MARQUES NETO, por outro lado, aponta três espécies distintas de espaços de autorregulação no Brasil. A primeira é a autorregulação delegada, em que há a transferência legal de competências regulatórias estatais para determinada entidade de direito privado (como a OAB, o CONFEA), o que acaba neutralizando a consensualidade e a livre adesão que marcam o instituto ${ }^{98}$. A segunda é a autorregulação induzida, em que a atividade é exercida por instâncias da sociedade por incentivo ou recomendação do Poder Público, como acontece nos institutos de certificação de processos e produtos (por exemplo, a certificação de produtos e equipamentos de telecomunicações, em que a Anatel se vale de entidades privadas, apenas as reconhecendo - cf. inciso XIII do artigo 19 da Lei $\mathrm{n}^{\circ}$ 9.472/97). Por fim, em terceiro lugar, há a autorregulação espontânea, criada por livre disposição e pelos agentes privados, independente de qualquer ação estatal, como acontece com os selos de produtos agroindustriais (como os selos de produtos orgânicos, por exemplo) ${ }^{99}$.

Entretanto, para o que aqui nos importa, é relevante deixar claro que a autorregulação não se confunde de forma nenhuma com a regulação estatal, da mesma forma que, embora envolva grande carga de liberdade dos atores econômicos, não se confunde também com a ausência absoluta de regulação ${ }^{100}$. Trata-se de uma hipótese alternativa, que se encontra justamente entre a regulação (estatal ou administrativa) e a ausência desta. De um certo modo, como ensina Vital MOREIRA, "o conceito de autoregulação aponta para o sentido do auto-equilíbrio dos mecanismos económicos. $O$ paradigma do primeiro conceito de auto-regulação económica é o da regulação

\footnotetext{
${ }^{98}$ Mas isso não extrai o caráter de autorregulação. Como ensina Vital MOREIRA, "[a] auto-regulação só é auto, na medida em que é estabelecida por uma instituição associativa ou representativa dos próprios agentes regulados, sendo de eficácia restringida aos membros da categoria 'profissional' em causa. Mas para cada um deles, individualmente considerado, as normas e medidas de regulação são heterônomas, a que eles não podem furtar-se (salvo abandonando a associação, nos casos de auto-regulação puramente privada)." (Auto-Regulação Profissional e Administração Pública, op. cit., página 56)

${ }^{99}$ Regulação Estatal e Autorregulação na Economia Contemporânea, op. cit., página 90-91.

${ }^{100}$ MOREIRA, Vital, Auto-Regulação Profissional e Administração Pública, op. cit., página 52. Notese, entretanto, que é o próprio Vital MOREIRA que salienta que, sob um certo sentido, a autorregulação se dá também pelo próprio mercado, como alternativa à total liberdade. Segundo esse autor, "no léxico clássico a economia era auto-regulada pelo mercado, pelo que não carecia de regulação externa. Aqui, o conceito de auto-regulação aponta para o sentido do auto-equilíbrio dos mecanismos económicos. $O$ paradigma do primeiro conceito de auto-regulação económica é o da regulação 'natural' através da livre concorrência, prescindido de qualquer norma exterior, ou seja, da regulação 'artificial'. Quando Adam Smith se referia à «mão invisível» do mercado como instância reguladora da economia, ou quando os neoliberais reclamam a abolição da regulação e a devolução para a auto-regulação, estão a referir este sentido. Aqui auto-regulação significa ausência de regulação, no sentido em que definimos esse conceito, enquanto regulação artificial." (op. cit., página 53)
} 
'natural' através da livre concorrência, prescindindo de qualquer norma exterior, ou seja, da regulação 'artificial"'101.

Ou seja, uma das alternativas à regulação estatal é delegar aos atores privados de determinado sistema econômico a possibilidade de se autorregularem, o que a transforma em importante conceito em vista da busca de limites à atividade regulatória. Alternativa esta que deve levar em conta elementos que apresentaremos mais adiante.

\section{II.4. Funções da regulação administrativa da economia: a compatibilidade da livre iniciativa com os objetivos da ordem econômica}

Dissemos linhas acima que toda a intervenção do Estado no domínio econômico deve se vincular aos objetivos encartados no artigo 170 da Constituição Federal. O mesmo logicamente deve ser afirmado com relação à atividade de regulação administrativa da economia, que deve compatibilizar a preservação das condições de exploração das atividades econômicas (liberdade de iniciativa econômica) com o cumprimento dos objetivos da ordem econômica positivados no referido artigo 170 da Constituição Federal ${ }^{102}$.

Aqui, entretanto, releva notar o papel estrutural dado pelo Texto Constitucional ao tema da livre iniciativa, alçado pela Carta tanto como fundamento da República Federativa do Brasil (art. $1^{\circ}$, IV) como da ordem econômica (art. 170). Com isso em mente, três notas sobrelevam. Em primeiro lugar, que o sistema econômico brasileiro é inegavelmente uma economia de mercado (em que as decisões de produção, investimento e consumo são tomadas pelos sujeitos econômicos privados, conforme lição de Vital MOREIRA ${ }^{103}$ ). Em segundo, que esse sistema econômico é regido por um modo de produção capitalista, no qual $(\boldsymbol{i})$ o produto social é apropriado pela iniciativa privada, (ii) a direção do processo de produção se orienta pela na busca pelo lucro e (iii) em que a produção de cada produtor possui natureza mercantil (i.e. traduz-

\footnotetext{
${ }^{101}$ Auto-Regulação Profissional e Administração Pública, op. cit., página 53.

${ }^{102}$ Cf. MARQUES NETO, Floriano de Azevedo, Regulação Econômica e suas Modulações, op cit., página 35.

${ }^{103}$ A Ordem Jurídica do Capitalismo, op. cit., páginas 24-25.
} 
se em dinheiro ${ }^{104}$. Por fim, em terceiro lugar, é justamente em função da regra da livre iniciativa, fundada em uma economia de mercado capitalista, que devem incidir as medidas regulatórias implementadas pelo Poder Público.

Com efeito, é fácil perceber que o fato de haver a Constituição erigido a livre iniciativa como fundamento da República e da ordem econômica brasileira não afasta ou muito menos fragiliza o dever do Estado de regular a economia. Muito ao contrário, mostra-se obrigatória a intervenção estatal sempre que necessária se mostrar a tutela da valorização do trabalho humano, da soberania nacional, da propriedade privada e sua função social, da livre concorrência, da defesa do consumidor, do meio ambiente, da redução das desigualdades regionais e sociais, da busca do pleno emprego ou do tratamento favorecido para as empresas de pequeno porte brasileiras. Nesse sentido, concorda-se com Cass R. SUNSTEIN quando diz que a legitimação das normas regulatórias vai muito além das chamadas falhas de mercado (que subsistiriam num aspecto intramercado, ou de mera manutenção das condições de existência do mercado), mas perpassa elementos extra-mercado de estatura constitucional ${ }^{105}$.

Segundo aponta o autor (referindo-se certamente ao sistema americano, mas que calha bem ao caso brasileiro), fundamentam a atividade regulatória do Estado: (i) a redistribuição de recursos entre os indivíduos; (ii); a blindagem de direitos inalienáveis dos cidadãos; (iii) a concretização de vontades e aspirações coletivas que não necessariamente convergem com as deliberações democráticas majoritárias; (iv) o direcionamento cognitivo da sociedade em temas de interesse coletivo; (v) a indução a práticas isonômicas em relação a segmentos sociais desfavorecidos - submissão social - (vi) o direcionamento do consumo em situações que induzem à transformações sociais (não logicamente substituindo preferências sociais por preferências "estatais", mas dando concreção à normas constitucionais e legais mais abrangentes ${ }^{106}$ ); (vii) a proteção contra a irreversibilidade de fatores nocivos

\footnotetext{
${ }^{104}$ Cf. MOREIRA, Vital, A Ordem Jurídica do Capitalismo, op. cit, página 28.

${ }^{105}$ After the Rights Revolution: Reconceiving the Regulatory State, Cambridge: Harvard University Press, 1990, páginas 47-55.

106 "Um regime geral de escolhas deliberativas através de controle governamental de desejos e crenças é com certeza a característica central dos regimes totalitários. Ninguém pode negar que um regime desse tipo seria intolerável. Mas seria mais peculiar tomar esse ponto como a razão para privar os cidadãos em um sistema de escolha democrática do poder de implementar aspirações coletivas através da lei, ou para, contrapondo, fornecer informação e oportunidades, preferências e crenças que se adaptaram a um
} 
à sociedade (problemas ambientais, extinção de animais, elementos naturais, etc.); e (viii) a blindagem do próprio Poder Público contra a captura por parte de grandes corporações econômicas (fenômeno chamado pela teoria econômica como rentseeking $\left.{ }^{107}\right)^{108}$.

Como se pode ver, talvez estejamos aqui defendendo uma espécie de combinação dos quatro modelos regulatórios vislumbrados por Tony PROSSER, ou seja, $(i)$ a regulação voltada à eficiência econômica e à escolha consumerista, (ii) a que visa a proteção de direitos e serviços básicos, (iii) a que tem como mote alcançar a solidariedade social e (iv) a que busca funcionar como fórum aberto à participação e deliberação dos atores envolvidos, servindo de mecanismo procedimental para o arbitramento de interesses públicos legítimos e contrapostos ${ }^{109}$. No geral, como fundamento de uma regulação administrativa sensata e voltada aos problemas da sociedade, nenhum dos pressupostos apresentados pelo autor merece ser descartado, mas, ao contrário, devidamente considerados no modelo regulatório nacional.

E é justamente em função deste caráter bastante social da regulação econômica (estatal e administrativa, vale dizer) que não faz muito sentido entre nós distinguir, como faz com alguma frequência parte da doutrina, a regulação estritamente econômica de uma regulação social mais ampla, voltada a consecução de finalidades públicas extramercado. Em um país marcadamente desigual como o Brasil, em constante processo de implementação das garantias constitucionais mais elementares, parece evidente que o instrumento da regulação deva ser primordialmente utilizado como forma de redistribuição de riqueza, de inclusão social, de correção de distorções

injusto e também questionável status quo" (SUSTEIN, Cass R., After the Rights Revolution, op. cit., página 47 - tradução livre).

${ }^{107}$ Como anota Robert KUTTNER, "grupos de interesse tem perseguido políticos apenas para conseguir benefícios às custas de outros grupos de interesse. Por analogia à teoria econômica, este fenômeno foi descrito como 'free riding' ou 'rent-seeking. Ao passo que os mercados por definição se otimizaram, políticos por definição desviaram recursos e pioraram os resultados" (Everything for Sale: the virtues and limits of markets, Nova York: The University of Chicago Press, 1999, página 34 - tradução livre).

${ }^{108}$ Cf. SUNSTEIN, Cass R., After the Rights Revolution, op. cit., páginas 55-71.

109 The Regulatory Enterprise: Governement, Regulation and Legitimacy, Nova York: Oxford University Press, 2010, páginas 11-19. Sobre a regulação como mecanismos de equilíbrio e arbitramento de interesses contrapostos ver o interessante estudo de SUNDFELD, Carlos Ari e CÂMARA, Jacintho Arruda, Produtos perigosos: como a regulação equilibra interesses conflitantes?, in Revista Brasileira de Direito Público - RBDP, n 34, Belo Horizonte: Fórum, jul/set 2011, páginas 73-90. 
sociais, de busca de emancipação econômica, de desenvolvimento nacional, de participação social, etc. Afinal, como lembra Calixto Salomão FILHO:

"[N]ão há justificativa para centrar a filosofia regulatória em torno da eficiência. Ela deve necessariamente ser direcionada precipuamente à redistribuição, única forma de expandir, de maneira estruturada e linear, o consumo pela sociedade. Ao fazê-lo, elimina também as ineficiências alocativas da concentração do conhecimento econômico, na medida em que expande a base de coleta de dados sobre preferências individuais. "110

De todo modo, uma nota importante sobre o tema diz com o fato de a regulação (como de resto qualquer intervenção estatal ou, de forma ainda mais abrangente, como qualquer ato produzido pelo Poder Público) somente ter lugar com a existência de fundado interesse público. Portanto, de nossa parte, mesmo sendo plenamente viável e até mesmo desejável a intervenção regulatória administrativa na economia, há para o Poder Público, como condição de legitimidade da atividade, o dever de demonstrar e comprovar a existência de real interesse público consubstanciado em algum dos objetivos encartados no artigo 170 da Constituição Federal a dar fundamento à medida. Na ausência desta, a intervenção se mostra certamente antijurídica e passível de questionamento. A observação aqui colocada nada tem de inovadora e representa apenas um dos pressupostos mais elementares da atividade estatal, vale dizer, a existência de fundado interesse público.

Mas não é só. Há de haver também limites à intervenção estatal na economia, principalmente de matiz regulatória, que é o que mais nos preocupa no presente estudo.

\footnotetext{
${ }^{110}$ Regulação, Desenvolvimento e Meio Ambiente, in FILHO, Calixto Salomão (org.), Regulação e Desenvolvimento: novos temas, São Paulo: Malheiros Editores, 2012, página 26. Note-se também que a mesma ideia fundamenta a preocupação de Norbert REICH quando alega ser a deregulation norte americana (focada apenas no mercado) inaplicável ao cenário europeu, que assistiu um incremento regulatório de cunho social (A Crise Regulatória: ela existe e pode ser resolvida? - Análise comparativa sobre a situação da regulação social nos Estados Unidos e na Comunidade Econômica Européia, in MATTOS, Paulo Todescan Lessa et al (coords.), Regulação Econômica e Democracia - O Debate Europeu, São Paulo: Singular, 2006, 17-52). De todo modo, parece fazer sentido a observação de Floriano de Azevedo MARQUES NETO no sentido de esta distinção entre regulação econômica e social ser atualmente apenas acadêmica no Brasil, já que "[e]m maior ou menor grau toda atividade econômica enseja externalidades positivas ou negativas, justificadoras de uma regulação de corte social. (...) Isso faz com que, no exercício da regulação a seu cargo, o Estado tenha de combinar o equilíbrio sistêmico com a promoção de políticas públicas. A regulação estatal, portanto, não pode ser meramente reativa ou ordenadora. Terá um caráter proativo e planejador, porém pautado por vetores de equilíbrio, ponderação e responsividade." (Regulação Econômica e Suas Modulações, op. cit., página 36)
} 


\section{II.5. Sobre a importância de se estabelecer limites à intervenção regulatória administrativa na economia}

De um modo geral, a importância de haver limites à intervenção do Estado na vida social dos indivíduos, seja de natureza econômica ou mesmo em temas mais cotidianos, já foi aqui ressaltada. Ela se refere justamente aos riscos de o Poder Público pretender substituir as escolhas diárias das pessoas, trocando a decisão pessoal de cada um pela da burocracia, o que chamamos acima de infantilização da sociedade. Entretanto, a par disso, outros elementos chamam a atenção para a necessidade de se estabelecer limites específicos à atividade regulatória administrativa.

Como também já se disse aqui, a regulação econômica, como instituto tipicamente de direito administrativo, somente ganhou maior importância com as reformas administrativas dos anos noventa do século passado e com a criação das chamadas agências reguladoras. Pois para além de mero modismo ou elucubração doutrinária, os estudiosos que se debruçaram sobre o assunto sempre alertaram para uma mudança estrutural na própria sociedade e no aumento da complexidade da figura do Estado, fazendo emergir a necessidade de se criar uma nova forma de ordenação social. Jacques CHEVALLIER, vimos acima, fala de um Estado pós-moderno ${ }^{111}$; Gustavo ZAGREBELSKY prefere tratar do que chama de Estado pluralista e democrático $^{112}$; Massimo Severo GIANNINI utiliza o termo Estado pluriclassista ${ }^{113}$; Gianfranco POGGI se refere apenas ao Estado moderno ${ }^{114}$; Gomes CANOTILHO fala em uma sociedade marcada pela "hipercomplexidade social" ${ }^{115}$; Jürgen HABERMAS alerta para o que chama de "sociedades que passaram para um nível de fundamentação pós-convencional"116.

Cada um a seu modo, todos estes autores retratam o incremento da complexidade das relações sociais e econômicas dos indivíduos, o que dá ensejo ao

\footnotetext{
${ }^{111}$ O Estado Pós-Moderno, op. cit, páginas 16-22.

${ }^{112}$ El derecho dúctil: Ley, derechos, justicia, 8ª ed., Madrid: Editorial Trotta, 2008, páginas 30-41.

${ }^{113}$ Premissas Sociológicas e Históricas del Derecho Administrativo, Madrid: Instituto Nacional de Administración Pública - INAP, 1980, páginas 65-68.

${ }^{114}$ A Evolução do Estado Moderno, Rio de janeiro: Zahar Editores, 1981, páginas 125 ss.

${ }^{115}$ Direito Constitucional e Teoria da Constituição, $7^{\mathrm{a}}$ ed., Coimbra: Almedina, 2007, página 1353.

${ }^{116}$ Direito e Democracia: entre facticidade e validade, vol. II, Rio de janeiro: Tempo Brasileiro, 2003, página 38.
} 
surgimento e reconhecimento de uma pluralidade de valores e interesses legítimos e heterogêneos, titularizados por forças políticas e sociais variadas dentro do mesmo corpo social, cumprindo ao Estado, por óbvio, tutelá-las. Esse fenômeno (e não um mero modismo teórico) acabou levando o Poder Público atual (genericamente falando) a repensar as formas disponíveis de regulação social, fazendo surgir o que hoje chamamos de regulação econômica, marcada, como vimos anteriormente, pelo pragmatismo e pela flexibilidade de seus comandos. Em verdade, o que há é que a regulação, como conceito, justamente por tratar das necessidades sociais sob a perspectiva de equilíbrio dos interesses em jogo, da negociação, da consensualidade e das concessões recíprocas, acaba por manejar de forma mais eficiente a compatibilização de interesses públicos legítimos porém nem sempre coincidentes. É a chamada postura de mediador ativo do Estado, na feliz acepção de Floriano de Azevedo MARQUES NETO ${ }^{117}$.

O resultado desse processo é um inegável crescimento da incidência regulatória do Estado em diversos setores da economia, tanto nos historicamente ocupados e monopolizados por entes estatais como em novas áreas, tradicionalmente geridas pelo mercado $^{118}$. Isso não representa logicamente a perda de importância da lei como instrumento primário de ordenação social, à qual é outorgada atualmente um papel publicizante fundamental a respeito de determinadas matérias. Segundo anota José Manuel Sérvulo CORREIA, cuida-se aqui do tema da reserva legal, que tem por finalidade garantir que o equacionamento normativo das questões mais relevantes da sociedade seja objeto de debate público, de conhecimento do eleitorado, e travado por diversas correntes de opinião partidariamente institucionalizadas. Esso aspecto, em sua opinião, eleva o Legislativo à sede institucional dos debates políticos, uma espécie de caixa de ressonância da opinião pública apto à perequação dos interesses plurais da sociedade $^{119}$.

\footnotetext{
${ }^{117}$ Interesses Públicos e Regulação Estatal, São Paulo: Malheiros Editores, 2002, página 163.

${ }^{118}$ Como anota Floriano de Azevedo MARQUES NETO, "[d]e há uns dez anos para cá, força dos processos de reorganização do papel do Estado (...), verifica-se uma forte redução na intervenção direta estatal no domínio econômico. (...) Paralelamente, aumenta a intervenção estatal sobre o domínio econômico não só nos setores em que o Estado se retira da exploração direta de atividade econômica, como também sobre outros setores em que a atuação regulatória estatal era tíbia. (...) É assim que verificamos o engrandecimento e a reestruturação da regulação estatal sobre setores com o a saúde suplementar, vigilância sanitária, uso e exploração de recursos hídricos, transportes, entre outros." (A Nova Regulação dos Serviços Públicos, op. cit., página 15)

${ }^{119}$ Cf. Legalidade e Autonomia Contratual nos Contratos Administrativos, Coimbra: Almedina, 1987, páginas 41-42.
} 
De todo modo, fato é que a regulação administrativa da economia nunca incidiu em tantos setores e sobre tantos temas como nos dias de hoje. Pois a análise de alguns exemplos extraídos de casos práticos demonstra a um só tempo o aumento da incidência regulatória que mencionamos, como também os diferentes mecanismos utilizados pelo Poder Público para induzir a livre iniciativa.

O primeiro exemplo pode ser extraído do setor portuário. Desde 1993, quando foi promulgada a Lei $\mathrm{n}^{\circ} 8.630 / 93$, a instalação portuária de uso privativo, isto é, a exploração privada de portos para fins próprios, dependia da descoberta de uma área adequada para a instalação, da autorização da autoridade portuária e do investimento privado. Era ainda permitido o uso misto de tais terminais portuários, seja para movimentação de carga própria como de carga de terceiros, o que fazia sentido para, além de possibilitar o escoamento do próprio carregamento, funcionar como mecanismo de auxílio à incapacidade dos portos públicos de dar vazão à crescente demanda.

Em 05 de junho de 2001 foi editada a Lei $n^{\circ} 10.233$, que reestruturou os transportes aquaviários e criou a Agência Nacional de Transportes Aquaviários ANTAQ, com competência também para regular o setor de portos públicos e privativos. Por sua vez, em 2008 foi editado o Decreto $n^{\circ}$ 6.620/08 que fez duas importantes mudanças no setor: $(i)$ primeiro, condicionou a autorização para a exploração de portos privativos à compatibilidade do empreendimento a um Plano Geral de Outorgas a ser editado pela ANTAQ (e que só foi concretizado em abril de 2009); e (ii) em segundo lugar, definiu-se que o mencionado uso misto somente teria lugar para "movimentação preponderante de carga própria e, em caráter subsidiário e eventual, de terceiros, em terminal portuário de uso misto" (art. 35, II).

Foi então que a ANTAQ, no exercício de suas competências regulatórias, editou a Resolução no 1695-ANTAQ, de outubro de 2010, a qual criou diversas formalidades (absolutamente relevantes, ressalte-se) a serem preenchidas pelos particulares que pretendessem explorar uma área costeira qualquer como instalação portuária de uso privativo. Mas mais importante, definiu-se que o uso misto de tais terminais somente seria admitido, em caráter complementar ou eventual, caso a movimentação de carga de terceiro fosse exatamente da mesma natureza da carga 
própria autorizada ${ }^{120}$. Caso contrário, a outorga deveria ser feita por meio de concessão precedida de licitação ${ }^{121}$. Segundo o Diretor-Geral da ANTAQ à época (Sr. Fernando Antonio Brito Fialho), a intenção da norma é "valorizar o conceito de porto público (onde várias empresas operam sob o guarda-chuva de um administrador e prestam serviço a terceiros)”. Já para o Ministro da Secretaria Especial de Portos à época (Sr. Pedro Brito, atual Diretor da ANTAQ até fevereiro de 2014), "[o] terminal privativo não deve funcionar como centro de lucro, mas como um centro de custo" ${ }^{122}$, dando a entender que investimentos privados em infraestrutura que acaba auxiliando o serviço portuário (eis que auxilia em alguma medida no escoamento de cargas) não podem resultar em receitas privadas, mas sim ser encarados como benemerência.

Embora legítima do ponto de vista da política regulatória, pelas palavras dos responsáveis pela ANTAQ e pela Secretaria Especial de Portos, parecia presente algum tipo de distorção a respeito da função e importância dos atores privados nos serviços portuários.

Não obstante, em dezembro de 2012 foi editada a Medida Provisória $\mathrm{n}^{\circ} 595$, que instituiu um novo marco regulatório no setor portuário e, entre outras alterações, acabou com a distinção entre carga própria e carga de terceiro criada pelo

${ }^{120}$ A regra consta da teleologia das definições constantes do artigo $2^{\circ}$ da Resolução $n^{\circ}$ 1695-ANTAQ. Com efeito, o terminal portuário é definido como aquele utilizado para movimentação ou armazenagem de carga próprias ou de terceiros (inciso III). Por sua vez, a carga de terceiros é aquela que se mostra compatível com as características técnicas da infraestrutura do terminal autorizado, mas que cuja operação deve ser eventual e subsidiária (inciso V). Uma operação eventual é aquela realizada de forma acessória (inciso $\mathrm{VI}$ ), ao passo que a operação subsidiária se caracteriza pela "movimentação $e$ armazenagem de cargas de terceiros, realizadas por terminais portuários de uso privativo misto, em regime de complementariedade da carga própria declarada" (inciso VII). Daí a conclusão, bastante óbvia, de que o uso misto de terminais portuários somente seria admitido para utilização de carga de terceiros em casos absolutamente excepcionais e cuja carga seja de mesma natureza da própria carga movimentada pela autorizatária.

${ }^{121}$ Esta discussão logicamente despertou o interesse do TCU, devidamente provocado pelas associações que defendem os interesses dos portuários e administradores de portos públicos. Ao se falar em desvio na utilização de terminais portuários privativos mistos por conta do uso predominante para movimentação de cargas de terceiros, surge o tema da equiparação aos portos públicos, outorgados por meio de concessão precedida de licitação. Segundo o TCU, "restaram claras as falhas e impropriedades que têm ocorrido nestes casos, no tocante à prática de concorrência assimétrica entre os terminais de uso misto e os terminais públicos, além de autorizações realizadas pela Antaq sem o cumprimento de todos os requisitos previstos para a boa e regular operação dos terminais, conforme preveem as normas em vigor, fatos que acabam por se constituir em burla à regra de que a delegação da prestação de serviços públicos aos particulares deve se dar mediante prévia licitação, conforme previsão constitucional e legislação correlata". O tema é discutido no Acórdão 554/2011 - Plenário, Rel. Min. Raimundo Carreiro, DOU de 17.03.2011.

${ }^{122}$ Cf. O Estado de S. Paulo, Governo restringe instalação de portos privados, Economia \& Negócios, 18.01.2010. Disponível em: http://www.estadao.com.br/noticias/economia,governo-restringe-instalacaode-portos-privados, $497436,0 . \mathrm{htm}$. 
Decreto $n^{\circ}$ 6.620/08 e perpetuada pela Resolução n ${ }^{\circ}$ 1695-ANTAQ. Entretanto, neste novo modelo, além de os agora chamados terminais de uso privado (previstos no art. $2^{\circ}$, IV, da MP) somente terem seu funcionamento autorizado pela ANTAQ após chamamento e processo seletivo públicos $\left(\operatorname{art.} 8^{\circ}\right)$, não há na norma qualquer menção à possibilidade de utilização destes terminais para movimentar cargas de terceiros. Com isso, o que era ainda uma tendência no regime do Decreto $n^{\circ}$ 6.620/08 (limitação de movimentação de carga de terceiros em terminal privativo) parece agora ter se tornado uma regra que veda completamente esse tipo de uso dos terminais privados. Portanto, o novo regime portuário brasileiro, tal qual disciplinado pela MP $\mathrm{n}^{\circ} 595 / 12$, acabou por comprovar o senso de desconfiança que o próprio setor estatal nutre em relação ao papel dos atores privados.

A Anvisa é outra fonte de exemplos interessantes. Em novembro de 2009 o órgão editou a RESOLUÇÃO RDC no 56/09 proibindo "em todo o território nacional a importação, recebimento em doação, aluguel, comercialização e o uso dos equipamentos para bronzeamento artificial, com finalidade estética, baseados na emissão de radiação ultravioleta". A norma foi fundamentada na alegação de que a atividade seria cancerígena, segundo estudos desenvolvidos pela IARC - International Agency for Research on Cancer e nos termos do que restou discutido em audiência pública realizada. Com isso, por meio do exercício de atividade reguladora, extinguiu-se totalmente a atividade econômica consistente no oferecimento de serviços de bronzeamento artificial.

O órgão de classe dos comerciantes, a Associação Brasileira de Bronzeamento Artificial - ABBA, recorreu ao Judiciário questionando a legalidade da medida. O Juízo da $4^{\text {a }}$ Vara Federal de Porto Alegre concedeu a liminar para suspender os efeitos da norma sob a alegação de ausência de parâmetros sobre a periculosidade ou nocividade da atividade em questão, notadamente em função da ausência de informações sobre o tempo de exposição necessário para o alegado desenvolvimento de câncer $^{123}$. A Anvisa recorreu da decisão defendendo a legitimidade da vedação por estar baseada em estudo científico, objeto de consulta pública, bem como porque "o princípio do livre exercício da atividade econômica não deve prevalecer frente à proteção da

\footnotetext{
${ }^{123}$ Cf. Ação Ordinária no 0001024-08.2010.404.7100/RS, J. Jurandi Borges Pinheiro, DE de 19.01.2010.
} 
saúde pública, assegurada na Constituição" ${ }^{124}$. Dias depois, o TRF da $4^{\text {a }}$ Região revogou a liminar baseado na presunção de legalidade da norma (competência normativa) e no fato de a atividade buscar fins meramente estéticos, o que desbalancearia a equação livre-iniciativa/saúde pública ${ }^{125}$.

Consultado sobre a questão, o Diretor da Anvisa disse que a Agência tem não só o poder, mas também o dever de regular sobre o que faz bem ou mal à sociedade brasileira. Segundo afirmou, o bronzeamento não traz benefícios à saúde,

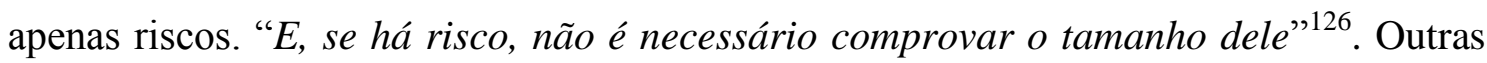
medidas judiciais foram ainda intentadas contra a RESOLUÇÃO RDC n $n^{\circ}$ 56/09 ${ }^{127}$, entretanto, igualmente sem sucesso. Atualmente, a utilização de câmaras de bronzeamento artificial com raios UVA para fins estéticos está vedada no Brasil.

Mas não é só. Em outra oportunidade, a mesma Anvisa resolveu regular a comercialização de alimentos com quantidade elevada de açúcar, gordura saturada, gordura trans, sódio e de bebidas com baixo teor nutricional. Conforme consta da RESOLUÇÃO-RDC no 24/2010, resolveu o órgão regulador em questão que no caso de oferta, propaganda, publicidade ou qualquer outro tipo de promoção comercial destes alimentos, as seguintes mensagens seriam obrigatórias (art. $6^{\circ}$, III):

“a) 'O (nomel marca comercial do alimento) contém muito açúcar e, se consumido em grande quantidade, aumenta o risco de obesidade e de cárie dentária'.

b) 'O (nomel marca comercial do alimento) contém muita gordura saturada $e$, se consumida em grande quantidade, aumenta o risco de diabetes e de doença do coração'.

\footnotetext{
${ }^{124}$ A afirmação é atribuída à ANTAQ pela decisão proferida na Suspensão de Liminar no 0001782 44.2010.404.0000/RS, do TRF4, em voto da lavra do Rel. Des. Federal Élcio Pinheiro de Castro, DOU de 05.02.2010.

${ }^{125}$ Cf. Suspensão de Liminar no 0001782-44.2010.404.0000/RS, Rel. Des. Federal Élcio Pinheiro de Castro, DOU de 05.02.2010.

${ }^{126}$ Cf. Agência Estado, Clínicas retomam sessões de bronzeamento artificial, 14.01.2010. Disponível em: http://www.abril.com.br/noticias/comportamento/clinicas-retomam-bronzeamento-liberado-justica526046.shtml.

${ }^{127}$ Refere-se aqui ao menos à Ação Ordinária $n^{\circ}$ 2009.72.05.004205-0/SC, da $1^{\text {a }}$ Vara Federal de Blumenau, e à Ação Ordinária no 0008253-87.2011.403.6105, da $6^{\mathrm{a}}$ Vara Federal de Campinas. Com relação a esta última, relevante notar que os argumentos utilizados pelo Judiciário Federal para manter a validade da norma editada pela Anvisa são absolutamente os mesmos que se valia a Suprema Corte Norte-americana na década de 80 do século passado para garantir as normas regulatórias de suas agencies, vale dizer, o primado da deferência. O tema será abordado mais adiante no texto.
} 
c) 'O (nome/ marca comercial do alimento) contém muita gordura trans e, se consumida em grande quantidade, aumenta o risco de doenças do coração'.

d) 'O (nomel marca comercial do alimento) contém muito sódio e, se consumido em grande quantidade, aumenta o risco de pressão alta e de doenças do coração'."

Aqui, portanto, há muito do que falávamos linhas acima sobre intervenções com notória tendência à infantilização da sociedade, em que a Administração Pública opta por substituir escolhas morais dos indivíduos e realizar decisões prévias em seu nome. Isso porque, ao que parece, resolveu a Anvisa ignorar o fato de que a maioria da população reconhece a existência de comidas mais ou menos nutritivas e com capacidade de causar maiores ou menores danos à saúde, conforme denota, a toda evidência, a existência de um mercado próprio de comidas light, diet, orgânicas e saudáveis (ainda que parte significativa da população opte - legitimamente, é bom ressaltar - por consumir comidas não tão saudáveis), consistindo uma espécie de autorregulação do próprio setor alimentício. A enviesada percepção administrativa foi lucidamente sumariada por José Vicente Santos de MENDONÇA nos seguintes termos:

"A intervenção do Estado, que não é, em si mesma e em todos os casos, um mal, passa a sê-lo quando ignora a autonomia moral do indivíduo e trata cidadãos, pais e responsáveis como uma grande massa de agentes relativamente incapazes, sempre prontos a serem instruídos, corrigidos ou orientados a um 'melhor caminho'.

Repita-se: o Estado pode ser maior ou menor, conforme ditem as contingências e o referende a vontade popular por intermédio das urnas. Só não pode ser um Estado-babá; um Estado que desacredite na autonomia moral do indivíduo e o desestimule a buscar as melhores opções que ele, mas só ele, poderá averiguar e encontrar. Mais do que possivelmente inconstitucional, a regulação da Anvisa é, na essência, um mau sinal. Ela afirma que o Estado, a pretexto de informar, deve tutelar escolhas. Nem estou investindo, aqui, contra o controle da publicidade destinada ao público infantil - há quem diga que a Anvisa pressupõe uma hipervulnerabilidade do público infantil, que, na verdade, e ainda mais hoje, na era da informação, nunca existiu."

\footnotetext{
${ }^{128}$ Cf. A legitimidade da tutela pública e o cheese salada, Consultor Jurídico, 29.07.2010. Disponível em: http://www.conjur.com.br/2010-jul-29/legitimidade-tutela-publica-cheesesalada.
} 
A AGU chegou até mesmo a recomendar a suspensão da Resolução questionando a necessidade ou não de lei federal para regular a matéria, já que a própria Constituição Federal garantiria aos cidadãos os meios de defesa necessários para frear práticas que fossem nocivas à saúde. Entretanto, para o Diretor da Anvisa à época (Sr. Dirceu Raposo de Mello), a problemática da questão reside na liberdade de expressão. Segundo declarou, “[a] Resolução da Anvisa não restringe a liberdade de expressão. $O$ que a Agência quer é assegurar o direito do consumidor à informação"129.

Com base nesses três exemplos, independentemente do erro ou acerto dos posicionamentos tomados em cada caso narrado, ou ainda da legalidade e constitucionalidade de cada medida adotada por cada órgão, todos estes eventos demonstram claramente ao menos dois aspectos da atividade regulatória estatal no Brasil: (i) primeiro, de modo geral, não há uma noção do regulador sobre os limites da atividade regulatória, isto é, se há um núcleo a ser preservado no momento que se opta por limitar ou mesmo proscrever uma atividade econômica; e (ii) em segundo lugar, parece haver uma desconfiança crônica da capacidade dos atores privados em implementar pautas públicas ou garantir o bem comum; e ainda que conseguissem, parece que há uma noção geral de que estariam locupletando-se ilegitimamente da riqueza nacional.

Buscar pautas mais precisas para a intervenção estatal no domínio econômico, principalmente em face da atividade regulatória da Administração Pública, não é, portanto, uma questão irrelevante. Ao contrário, em se tratando de regulação econômica, que ao mesmo tempo em que enseja um relacionamento muito mais intenso entre Administração Pública e particulares, incide também em quaisquer atividades com um mínimo de relevância social (bens e serviços considerados essenciais), a busca por tais limites se faz fundamental.

Por outro lado, é também verdade que não se trata de uma preocupação moderna ou de um problema recente. Nos EUA, como se sabe, em vista de sua ampla experiência na regulação de atividades econômicas perpetrada por órgãos administrativos, há preocupações dessa ordem quase seculares. Com efeito, ainda em

${ }^{129}$ Cf. Diretor da Anvisa aborda propaganda de alimentos em audiência do Senado, 09.12.2010. Disponível em: http://portal.anvisa.gov.br/wps/content/anvisa+portal/anvisa/sala+de+imprensa/menu++ noticias + anos $/ 2010+$ noticias/diretor $+d a+$ anvisa + aborda + propaganda + de + alimentos + em + audiencia $\underline{+ \text { do+senado. }}$. 
1938 foi julgado pela Suprema Corte Norte-Americana o caso United States v. Carolene

Products Co., em que se decidiu que as hipóteses que envolvessem a regulação de atividades econômicas deveriam ser analisadas apenas sob o critério da racionalidade ${ }^{130}$. Entretanto, a famosa nota de rodapé número 4 do voto do Juiz Harlan Stone criou dois mecanismos de controle de normas restritivas posteriormente chamados de strict scrutiny e minimal scrutiny, em que se estabeleciam critérios para a aferição da necessidade de controles mais rígidos ou mais lassos sobre as regras interventivas ${ }^{131}$.

Em termos de regulação administrativa da economia, o caso fundamental, ainda que se refira a um controle judicial (judicial review), é o Chevron Inc. v. National Resources Defense Council. Nele, a Suprema Corte americana definiu o que Marcos Paulo VERÍSSMO chama de princípio da deferência, segundo o qual a análise da atividade normativa das entidades administrativas vinculadas a termos genéricos (como o é a liberdade econômica) deve se submeter a um teste duplo: "primeiro, implicaria verificar se o texto legal é, realmente, vago; depois, em caso positivo, implicaria verificar se a interpretação do texto legal, consagrada na ação administrativa, é razoável"132. Sendo a lei vaga e sua interpretação pela Administração

130 Cf. VERÍSSIMO, Marcos Paulo, Juízes Deferentes?, in Revista Brasileira de Estudos Constitucionais, $\mathrm{n}^{\circ}$ 22, Belo Horizonte: Fórum, abr/jun 2012, páginas 501-502.

${ }^{131}$ Sobre a famosa nota de rodapé $\mathrm{n}^{\circ} 4$ no caso United States $v$. Carolene Products Co. e sua interpretação, ver o interessante estudo de ELY, John Hart, Democracy and Distrust: A Theory of Judicial Review, Cambridge: Harvard University Press, 2002, páginas 75-77 e 101-104. Para Ely, o enfoque adequado para a revisão jurisdicional das normas restritivas de direitos básicos de liberdade "é semelhante ao que pode ser chamado de 'antitrust', em oposição a uma orientação 'regulatória' para os assuntos econômicos - ao invés de ditar resultados substantivos ela intervém apenas quanto o 'mercado', no nosso caso o mercado político, está funcionando mal de modo sistêmico (Uma analogia com o árbitro é também cabível: ele intervém apenas quando um time obtém uma vantagem injusta, não quando o time 'errado' faz gol). Não é justo dizer que o governo está 'funcionando mal' simplesmente porque às vezes ele gera resultados com os quais nós discordamos, ainda que fortemente (e afirmar que ele obtém resultados de que 'o povo' realmente discorda - ou discordaria, 'se compreendesse' - é um pouco mais do que meras projeções delirantes). Em uma democracia representativa, determinações de valor são feitas pela eleição de representantes, e se realmente nós desaprová-las podemos destituídos do cargo pelo voto. Mau funcionamento ocorre quando o processo não merece confiança, quando (1) os incluídos estão obstruindo os canais de mudança política para assegurar que continuem sendo incluídos e os excluídos permaneçam fora, ou (2) quando, embora ninguém esteja negando uma voz ou um voto, os representantes ligados a uma efetiva maioria estão sistematicamente desfavorecendo algumas minorias com base simplesmente em hostilidade ou uma recusa preconceituosa em reconhecer uma comunhão de interesses, e portanto negando à maioria a proteção garantida aos outros grupos pelo sistema representativo" (op. cit., páginas 102-103 - tradução livre).

${ }^{132}$ Controle Judicial da Atividade Normativa das Agências de Regulação Brasileiras, in ARAGÃO, Alexandre Santos (coord.), O Poder Normativo das Agências Reguladoras, Rio de Janeiro: Forense, 2006, páginas 398-399. 
razoável, ela não poderia ser substituída pela Corte por outra tida como mais aderente aos desígnios legais, resultando num critério de deferência ${ }^{133}$.

Entre nós, o tema também já foi objeto de reflexão da doutrina. Nesse sentido, há mais de trinta anos, dizia-nos Tércio Sampaio FERRAZ JÚNIOR que " $a$ mobilidade econômica de hoje que desequilibrou o papel do indivíduo como proprietário e agente econômico está a reclamar novos mecanismos da inventividade do constitucionalista. Pois, sem eles, permaneceremos nesta curiosa situação em que os verdadeiros limites constitucionais à intervenção estatal no domínio econômico são deslocados para a própria práxis do Estado, no sentido de que somos obrigados a ver como ele age para, então, saber o que dele se pode exigir" ${ }^{134}$. As preocupações permanecem estranhamente contemporâneas, com a diferença de que hoje a intervenção (regulatória) vem de diversos órgãos administrativos e incidem em quase todos os setores.

Parece óbvio, portanto, que à medida em que cresce a incidência regulatória maior também se mostra a importância de se precisar os limites dessa atividade. E em um momento histórico em que a regulação funciona como o grande instrumento de conformação do sistema econômico aos sistemas político e jurídico ${ }^{135}$,

\footnotetext{
${ }^{133}$ Sobre as conclusões do caso Chevron, ver também as críticas e sugestões de SUNSTEIN, Cass R., $O$ Constitucionalismo Após o New Deal, in MATTOS, Paulo (coord.), Regulação Econômica e Democracia: O Debate Norte-Americano, São Paulo: Editora 34, 2004, páginas 163-167.

${ }^{134}$ Fundamentos e Limites Constitucionais da Intervenção do Estado no Domínio Econômico, in Revista de Direito Público - RDP, $n^{\text {os }}$ 47-48, São Paulo: Revista dos Tribunais, 1978, p. 271.

${ }^{135}$ A regulação auxilia na conformação do sistema econômico ao político justamente na condução do mercado em maior ou menor grau aos interesses públicos tutelados pelo Estado. E o faz de forma bastante mais eficiente e adaptada ao timing cada vez mais dinâmico dos setores mercadológicos que necessitam da tutela estatal. A regulação conforma ainda o sistema econômico ao sistema jurídico pela edição de normas não tão rígidas, verticais e marcadamente perenes como as leis do Parlamento. As normas regulatórias teoricamente possuem a característica de serem mais flexíveis e horizontais, resultado de um relacionamento entre Poder Público e mercado mais consensual e menos autoritário. Segundo Floriano de Azevedo MARQUES NETO "a atividade regulatória oferece uma alternativa às soluções estritamente liberais (que apontam para a supressão de qualquer perspectiva de controle ou pretensão ordenadora da economia) para a incapacidade dos sistemas jurídico e político de dar conta às necessidades $e$ complexidades de um sistema econômico crescentemente autônomo e ao grau cada vez mais especializado e à autorreferência dos subsistemas que o integram (...) pois: i) permite a adequação aos níveis de especialização exigidos por cada setor da economia (cada subsistema); ii) enseja mais dinamismo e agilidade na função normativa, permitindo uma resposta do sistema regulatório mais ágil do que a resposta possível no âmbito do ordenamento estatal; iii) favorece uma maior integ ração entre os sistemas, uma vez que o engate entre eles não se dá pelo vértice da cada sistema e sim pela articulação no ambiente do próprio subsistema regulado (onde interagem os atores econômicos, sociais, estatais e os distintos interesses de cada qual); iv) favorece as mediações técnicas àquelas de matiz exclusivamente político, sem deixar de reconhecer naquelas um forte conteúdo de arbitragem de interesses." (Regulação Estatal e Autorregulação na Economia Contemporânea, op. cit., p. 84-85)
} 
sua incidência tende logicamente a crescer em abrangência e em intensidade. Os exemplos acima são apenas alguns dos problemas suscetíveis de ocorrer pela ausência de limites objetivos à atividade reguladora administrativa, ou, pior, pela crença do regulador que sua atividade não possui limite algum.

É, pois, em torno da busca por limites à atividade regulatória estatal que gira o presente estudo. E conforme se verá adiante, o tema da subsidiariedade emerge como relevante na medida em limita a intervenção regulatória e exige o devido respeito às capacidades privadas, colocando as coisas em seu devido lugar: a Administração regulando quando e onde se mostrar necessário e os atores econômicos atuando sem amarras desnecessárias ou instituídas a gosto do administrador de plantão. 


\section{CAPÍTULO III. A SUBSIDIARIEDADE CORRETAMENTE COMPREENDIDA}

O tema da subsidiariedade talvez seja um dos mais polêmicos do direito brasileiro. Muito se diz sobre ele, mas nem mesmo sua origem parece clara. É usado por vários ramos das ciência sociais, mas quase sempre com significados diferentes. Uns o tratam como um princípio jurídico, outros como se regra fosse; há ainda quem dele trate simplesmente como subsidiariedade. Possui também muitos defensores e outros tantos críticos ferrenhos. Seu fundamento jurídico (para quem nele acredita) figura como outro desafio, já que nem mesmo sobre isso a doutrina é uniforme.

Um pouco por conta de sua assimilação com a doutrina da igreja católica (o que acaba incitando defensores e críticos da própria igreja), outro tanto em função da referência ao liberalismo econômico (assunto que desperta o desconforto de muitos), fato é que a subsidiariedade figura como um tema naturalmente polêmico e, de certo modo, também pouco sistematizado pela doutrina. Há importantes e ótimas obras a respeito, mas talvez não com uma praticidade e uma preocupação em detalhar suas estruturas. A análise da sua origem e a verificação de seus campos de incidência são temas evidentemente fundamentais. Entretanto, há ainda lacunas e outras assimilações que devem ser adequadamente afastadas para que se perceba a relevância do mecanismo.

Importa-nos aqui, portanto, fazer um giro sobre a origem histórica da subsidiariedade (ao menos o que se pode dela extrair), sua concepção tradicional, as críticas que tem recebido atualmente e sua afirmação como vetor de restrição à intervenção estatal na economia.

\section{III.1. Subsidiariedade: origem, incompreensão e maleabilidade instrumental}

A palavra subsidiariedade tem origem ao termo subsídio (do latim 'subsidium'), que significa ajuda, auxílio, socorro ${ }^{136}$. Em termos gerais, traduz uma

${ }^{136}$ MARTINS, Margarida Salema d'Oliveira, O Princípio da Subsidiariedade em Perspectiva Jurídico-Política, Coimbra: Coimbra Editora, 2003, páginas 9-10. 
relação de interdependência e cooperação entre dois elementos ou instituições. Por outro lado, é realmente difícil tratar da origem da subsidiariedade como elemento sóciopolítico ou jurídico sem remeter o tema à doutrina social da igreja católica. Entretanto, outros estudiosos apontam que sua origem reside no próprio nascimento da instituição Estado.

Como anota Carlos Eduardo MALDONADO, há vozes remetendo as raízes políticas e filosóficas da ideia de subsidiariedade aos trabalhos de Proudhon e Stuart Mill, da mesma forma como há também autores indo mais além, vincando sua origem especificamente nos trabalhos de Aristóteles e Tomás de Aquino ${ }^{137}$. É nesse segundo grupo que se insere Reinhold ZIPPELIUS, para quem a dependência do homem a uma comunidade em busca do desenvolvimento da personalidade é o que motiva a criação do Estado como instituição, fazendo imediatamente surgir a questão, já adiantada por Aristóteles, dos riscos de um Estado ilimitado ${ }^{138}$. De fato, embora soe até mesmo fora de propósito suscitar estas concepções elementares sobre Teoria Geral do Estado, fato é que a finalidade das instituições estatais sempre foi a de auxiliar os indivíduos no atingimento de seus anseios, o que remete a ideia de que o espaço social é, por origem, dos indivíduos. Daí a levar o próprio ZIPELLIUS a defender que:

"Da exigência da maior autodeterminação possível deduz-se como
princípios estrutural o princípio da subsidiariedade: as comunidades
superiores só deverão assumir funções que as comunidades mais pequenas,
inferiores, não podem cumprir da mesma ou de melhor forma.
Efectivamente, quanto mais pequena for uma comunidade, tanto maior será
o contributo de cada indivíduo para a formação da vontade comunitária.
Portanto, quanto mais poder decisório se encontrar nas comunidades
inferiores, tanto maior será a medida em que os indivíduos se podem
afirmar na vida comunitária."

Mas parece que foi mesmo com a participação da igreja católica que a ideia de subsidiariedade ganhou algum corpo. De fato, desde a segunda metade do século XIX a igreja iniciou seu tratamento ao tema. Em 1891 foi promulgada a encíclica Rerum Novarum, que foi reconhecidamente a primeira menção a respeito da ideia de

\footnotetext{
${ }^{137}$ Human Rights, Solidarity and Subsidiarity: Essays toward a Social Ontology, Washington: RVP, 1997, página 73 .

${ }^{138}$ Teoria Geral do Estado, $3^{\mathrm{a}}$ ed., Lisboa: Fundação Calouste Gulbenkian, 1997, páginas 157-161.

${ }^{139}$ Teoria Geral do Estado, op. cit., página 159.
} 
subsidiariedade, ainda que sem referência expressa ao termo ${ }^{140}$. Entretanto, foi mesmo a partir da encíclica Quadragesimo Anno de 1931 que se enuncia a subsidiariedade de forma expressa e até mesmo clássica, nos seguintes termos:

"O fim natural da sociedade e da sua acção é coadjuvar os seus membros, não destruí-los nem absorvê-los. (...) Deixe pois a autoridade pública ao cuidado de associações inferiores aqueles negócios de menor importância, que a absorveriam demasiado; poderá então desempenhar mais livre, enérgica e eficazmente o que só a ela compete, porque só ela o pode fazer : dirigir, vigiar, urgir e reprimir, conforme os casos e a necessidade requeiram. Persuadam-se todos os que governam : quanto mais perfeita ordem hierárquica reinar entre as varias agremiações, segundo este princípio da função «supletiva» dos poderes públicos, tanto maior influência e autoridade terão estes, tanto mais feliz e lisonjeiro será o estado da nação." 141

A verdade é que o sentido dado pela igreja à ideia de subsidiariedade se distancia e muito de uma concepção jurídica ou mesmo política que o termo denota. Trata-se de uma concepção estritamente moral e fundada unicamente na visão católica do homem e da família cristã, uma alternativa até mesmo perspicaz para que o discurso todo da igreja não se restringisse a meros conselhos de caridade ${ }^{142}$. Como anota Margarida Salema d'Oliveira MARTINS, "para a Igreja Católica a igualdade que importa é a igualdade perante Deus e não perante os homens", o que torna praticamente impossível questionar ou mesmo avaliar intervenções estatais baseadas em "considerações puramente éticas, dificilmente convertíveis em deveres jurídicos" ${ }^{143}$.

\footnotetext{
${ }^{140}$ Cf. MILLON-DELSOL, Chantal, Le príncipe de subsidiarité, Paris: PUF, 1993, página 139. A certa altura do discurso contido na encíclica, afirma-se que "[q]uerer, pois, que o poder civil invada arbitrariamente o santuário da família, é um erro grave e funesto. Certamente, se existe algures uma família que se encontre numa situação desesperada, e que faça esforços vãos para sair dela, é justo que, em tais extremos, o poder público venha em seu auxílio, porque cada família é um membro da sociedade." (Encíclica Rerum Novarum, disponível em: http://www.vatican.va/holy_father/leo_xiii/ encyclicals/documents/hf_l-xiii_enc_15051891_rerum-novarum_po.html).

${ }^{141}$ Encíclica Quadragésimo Anno, disponível em: http://www.vatican.va/holy father/pius xi/encyclicals/ documents/hf p-xi_enc 19310515 quadragesimo-anno po.html. Posteriormente, mais quatro encíclicas foram editadas pela igreja católica reafirmando, cada uma a sua maneira, o ideal de subsidiariedade. Tratam-se da Mater et Magistra de 1961, da Pavem in Terris de 1963, Solicitudo rei socialis de 1987 e Centesimus Annus de 1991. Sobre o tema ver MARTINS, Margarida Salema d'Oliveira, O Princípio da Subsidiariedade em Perspectiva Jurídico-Política, op. cit., páginas 64-73.
}

${ }^{142}$ Cf. MILLON-DELSOL, Chantal, Le príncipe de subsidiarité, op. cit., página 139.

${ }^{143}$ O Princípio da Subsidiariedade em Perspectiva Jurídico-Política, op. cit., página 73. 
Pois se de um lado a igreja utilizou o mecanismo da subsidiariedade como uma forma de compensar a péssima condição dos trabalhadores no final do século XIX e a destruição do corporativismo do Ancien Régime (o que os deixava desprotegidos ante um capitalismo cujo Estado liberal não havia criado freios) ${ }^{144}$, de outro regimes fascistas também dele se valeram de alguma forma, por mais contraditório que isso possa parecer. Como anota Gilberto BERCOVICI, tanto na célebre Carta del Lavoro de Mussolini, quanto na Fuero del Trabajo da ditadura Franquista ou nas Cartas Brasileiras de 1937, 1967 e 1969 há menções expressas a um certo dever do Estado de respeitar a suficiência privada em seara econômica ${ }^{145}$, o que, de resto, demonstra uma captura da doutrina católica ${ }^{146}$. Segundo este autor, foi justamente esse o fundamento que levou à criação do capitalismo sem risco defendido pelos ideólogos da iniciativa econômico-privada brasileira, ou seja, aquele que prega " $a$ socialização dos prejuízos e a privatização dos lucros" ${ }^{147}$.

Mas não é só. O conceito de subsidiariedade encontrado notadamente nas encíclicas Rerum Novarum e Quadragesimo Anno fundamentou em grande medida as ideias do Ordo-Liberalismo da Escola de Friburgo. Com efeito, como anota Chantal MILLON-DELSOL, mesmo sem dependência religiosa oficial mas sob influência das

\footnotetext{
${ }^{144}$ Cf. LAPOINTE, Benoît, Le principe de subsidiarité sous l'éclairage de l'enseignement social de l'Eglise, in CHEVALLIER, Jacques (coord.), L'identité politique, Paris: PUF, 1994, páginas 448-449.

${ }^{145}$ Direito Econômico do Petróleo e dos Recursos Minerais, São Paulo: Quartier Latin, 2011, páginas 268-270.

${ }^{146}$ A certa altura de seu discurso, Gilberto BERCOVICI alega que a subsidiariedade foi primeiramente positivada com a Carta del Lavoro de Mussolini em 1927 (Direito Econômico do Petróleo e dos Recursos Minerais, op. cit., página 268), ignorando o registro da encíclica Rerum Novarum, de 1891. O caminho, entretanto, parece ter sido o inverso. O que ocorreu foi a apropriação da teoria da subsidiariedade pelo corporativismo, dando origem ao surgimento de regimes autoritários, como o fascismo e o franquismo. É o que aponta Chantal MILLON-DELSOL: "De resto, a 'doutrina social' permaneceu naturalmente exposta a uma outra tentação: a de valorizar indevidamente os grupos sociais, fermentos indispensáveis à concretização de suas ideias. Isto é o que aconteceu com o corporativismo, que iria transformar o princípio da subsidiariedade em sistema e, assim, desnaturar o que foi concebido como uma simples referência. O corporativismo represente o excesso da 'doutrina social', sua própria doença - porque termina mal, e só a história é um juiz objetivo. (...) O corporativista atual encontra a sua fonte principal em $R$. de La Tour du Pin, ele mesmo inspirado por Taparelli. Ele continua com C. Maurras, que chamou La Tour du Pin de seu 'mestre'. Ele inspirou o regime de Salazar, e, de forma derivada, o de Mussolini. A teoria corporativista repousa em uma antropologia especifica: o homem individual nada pode sem a comunidade a quem pertence. Assim, não há liberdade 'individual': esta exprime uma abstração, um erro revolucionário. Para nós esse discurso não é novidade: nós o encontramos em Althusius, seguido por Thomas de Aquino. Precisamente, a falha da teoria corporativista vem de sua inadequação para o seu tempo: ela vai terminar em ditadura porque é uma utopia, não passa de uma utopia do futuro, como o marxismo, mas uma utopia de regresso às base, em todo caso um sonho político." (Le príncipe de subsidiarité, op. cit., páginas 29-30 - tradução livre)

${ }^{147}$ Direito Econômico do Petróleo e dos Recursos Minerais, op. cit., página 270.
} 
ideias da igreja católica, influenciados especialmente pelo tomismo, que o pensamento neoliberal alemão na década de 30 do século passado emergiu ${ }^{148}$. Nas palavras da autora:

"O Ordo-Liberalismo deplora este individualismo e a massificação que ele enseja, mas não reclama um retorno à sociedade-comunidade anterior. Ele recusa a ideia corporativista que aniquila algumas liberdades em nome de um bem comum objetivamente definido, e endossa o individualismo sociológico como um atributo incontornável da modernidade. Ele exige no entanto a constituição de uma sociedade mais vibrante, cheia de grupos livremente constituídos e detentores de iniciativa, capazes, portanto, de mediar a relação entre o indivíduo e o Estado. A sociedade orgânica deu lugar à ideia de uma sociedade organizada, cuja necessidade se justifica menos por uma visão ontológica que pelo desejo de remover a tentação do estatismo. É aqui que o princípio [subsidiariedade] retoma um papel essencial, pois o estabelecimento de uma sociedade estruturada levanta a questão da distribuição de poderes." 149

E é também MILLON-DELSOL quem observa que a escola OrdoLiberal de Friburgo surge nesse período com ideias bastante inusuais, tais como privatização na medida do possível, nacionalização na medida do necessário, liberdade tanto quanto possível, autoridade tanto quanto necessário, etc. É que para os teóricos de Friburgo a liberdade sempre vem em primeiro lugar, o que demonstra ainda mais a compatibilidade de suas ideias com a teoria cristã da subsidiariedade. Nesse sentido, a autoridade estatal não é vista como um mal necessário, já que traduz utilidades ao indivíduo que suplantam os bens e as propriedades privadas. Daí a conclusão de que "se o homem é um ser social, ele encontra sua felicidade não apenas na suficiência material, mas em uma sociedade onde o patrimônio é preservado, a reputação garantida, a miséria combatida" ${ }^{150}$.

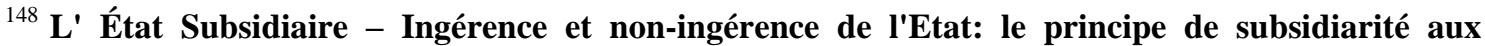
fondements de l'histoire européenne. Paris: PUF, 1992, páginas 171-172 - tradução livre. Há de fato traços marcantes pensamento de São Tomás de Aquino e da igreja católica em alguns escritos de Wilhelm RÖPKE, um dos formadores do Ordo-Liberalismo (juntamente com Walter Eucken, Hans GrossmannDoerth, Franz Böhm, Alfred Müller-Armack e Alexander Rüstow) conforme se verifica em International Order And Economic Integration, Dordrecht: D. Reidel Publishing Company, 1959, páginas 69-93. Igualmente ligando a doutrina Ordo-Liberal com a ideia de subsidiariedade da igreja católica ver também HERR, Teodor, La Dottrina Sociale Della Chiesa. Manuale di base, Piemme: G. Angelini, 1988, página 122.

${ }^{149}$ L' État Subsidiaire, op. cit., páginas 172.

${ }^{150}$ Le príncipe de subsidiarité, op. cit., página 58-59.
} 
De todas essas observações, ao menos duas conclusões parecem seguras. Em primeiro lugar, há uma certa maleabilidade na utilização da ideia de subsidiariedade. Embora forjada na doutrina do Vaticano, a ideia serviu para fundamentar uma serie de teorias político-econômicas muitas vezes antagônicas entre si, como o Ordo-Liberalismo alemão e o fascismo de Mussolini ou de Franco. Isso, ao contrário do que defendem alguns, denota que a subsidiariedade da intervenção estatal, como teoria, pode até ser bastante mal compreendida, mas é ideologicamente neutra. A esse tema, entretanto, voltaremos mais adiante.

Em segundo lugar, parece também bastante óbvio que foi justamente a associação da subsidiariedade à teorias sociais digamos pouco populares que tornaram o tema uma verdadeira celeuma. Sim, pois além da associação à igreja católica e ao fascismo, falar em liberalismo e todas as suas variações no Brasil configura quase uma afronta intelectual. Por outro lado, as origens da subsidiariedade, muito ligadas à doutrina católica, acabam fazendo incidir um certo ranço religioso ao tema, que sobrevive enquanto conceito político e também jurídico. De todo modo, dado a todos estes fatores, não é de se espantar que o vetor de subsidiariedade da intervenção estatal, seja em sua concepção original como em sua vertente mais moderna, tenha muitas vezes de dialogar com a incompreensão e com o preconceito.

\section{III.2. Concepção atual da subsidiariedade e seus campos de aplicação}

De tudo que se viu acima, tem-se que atualmente o critério de subsidiariedade que trata das relações indivíduos/Estado parte do pressuposto de que as instituições sociais prescindem do Poder Público para atingir seus objetivos ${ }^{151}$. Essa afirmação pode parecer temerária para quem foca em desigualdades materiais e sociais, mas o fato é que o Estado é uma abstração e serve para atingir determinadas finalidades, não substituir os indivíduos.

Nesse sentido, a subsidiariedade acaba funcionando como uma espécie de mecanismo de descentralização, no sentido de privilegiar as funções da entidade menor em relação à entidade maior. Nas palavras de Maria do Rosário

${ }^{151}$ Cf. MARQUES NETO, Floriano de Azevedo, Limites à Abrangência e à Intensidade da Regulação Estatal, in Revista de Direito Público da Economia - RDPE, no 1, Belo Horizonte: Fórum, jan/mar 2003, página 80 . 
VILHENA, "a comunidade maior só deverá actuar quando, e na medida em que, havendo necessidade de tal intervenção, esta se revele mais eficaz do que a actuação da comunidade menor; nesta medida, os grupos superiores só deverão executar aquelas tarefas que não possam ser eficientemente executadas pelos grupos inferiores" ${ }^{152}$.

No que respeita às relações estatais, trata-se de instrumento de acomodação de conflitos entre interesses públicos e privados, configurando uma espécie de proteção à esfera individual de intervenções do Poder Público que se mostrem desnecessárias e, portanto, ociosas. Ou como defende Fausto de QUADROS em lição já clássica, a subsidiariedade "conduz à aceitação da persecução do interesse público pelo indivíduo e por corpos sociais intermédios, situados entre ele e o Estado: família, as autarquias locais, as comunidades religiosas, os sindicatos e as associações empresariais, os partidos políticos, as Universidades etc. A subsidiariedade recusa, portanto, o monopólio da Administração na persecução do interesse público e leva à concretização do princípio da participação, que consiste numa manifestação da idéia de Democracia." ${ }^{153}$

Não pretendemos aqui logicamente entoar o mantra da atuação estatal secundária, desimportante ou mesmo uma regra de não ingerência estatal ${ }^{154}$, aos moldes de um liberalismo clássico e já ultrapassado. Não é disso que se trata. Cuida-se aqui tão somente trabalhar com a ideia de auxílio, de assistência, de intervenção do Estado com a finalidade de mediar, conciliar e a perseguir interesses públicos legítimos. Assim, temse que a intervenção estatal mostra-se legitima apenas quando necessária para garantir valores jurídicos considerados de interesse público, cuja sociedade não consiga alcançálos autonomamente. Subsidiário aqui, portanto, não significa secundário, mas sim auxiliar, que estimula, encoraja, contribui, que soma esforços para o atingimento de um bem maior a toda coletividade.

Em verdade, o que aqui se defende coincide exatamente com o que há 50 anos ensinava Luis SÁNCHEZ AGESTA:

\footnotetext{
${ }^{152}$ O Princípio da Subsidiariedade no Direito Comunitário, Coimbra: Almedina, 2002, página 30.

${ }^{153}$ O Princípio da Subsidiariedade no Direito Comunitário após o Tratado da União Europeia, Coimbra: Almedina, 1995, página 18.

${ }^{154}$ A respeito do tema ver MILL, John Stuart, Sobre a Liberdade, São Paulo: Hedra, 2010, páginas 183 e ss.
} 
"Subsidiário não quer dizer que o Estado deve fazer o menos possível ou que seria desejável suprimir a intervenção do Estado, caso seja viável. Tampouco significa que o Estado apenas tenha uma função supletiva ou secundária, no sentido de que o Estado se justifique apenas para suprir as deficiências. E seria ainda mais equivocado interpretar este principio como uma definição da natureza do Estado, ao que se atribuiria esta característica para defini-lo por uma função supletiva, secundária $e$ subalterna. (...) $O$ Estado tem uma função própria que o vincula à realização do bem comum. E desta mesma ideia de bem comum, em que se apoia a intervenção do Estado, deriva sua função subsidiária, como ajuda em nome do bem comum universal e da justiça distributiva." ${ }^{155}$

De todo modo, a subsidiariedade não funciona apenas como instrumento de relacionamento da sociedade com o Estado. Funciona também como mecanismo geral de arbitramento de competências que tem como base o privilégio do elemento menor ou mais próximo em relação ao maior ${ }^{156}$. Daí ser possível constatar que a subsidiariedade possui várias dimensões e pode ser estudada por diferentes ângulos ${ }^{157}$, possuindo, pois, diversos outros usos, como no plano do direito internacional, nas competências federativas, na teoria das normas concorrentes, no processo judicial, etc.

Assim, fala-se em um critério de subsidiariedade no estabelecimento das competências de organismos internacionais em relação aos países integrantes, o qual, segundo Rosemiro Pereira LEAL tem origem no princípio da operacionalidade dos tratados, que estabelece que "o sistema criado pelas normas comunitárias repugna a caoticidade e, portanto, deve estar em condições de realizar as atividades que lhe são próprias ${ }^{158}$. O exemplo mais evidente da aplicação da subsidiariedade neste campo - e que certamente mais fundamentou estudos sobre o tema -, é a União Europeia, que por

${ }^{155}$ El Principio de Función Subsidiaria, in Revista de Estudios Políticos, $\mathrm{n}^{\text {o }}$ 121, Madrid: Centro de Estudios Políticos y Constitucionales, jan/fev 1962, páginas 14-15 - tradução livre.

${ }^{156}$ Cf. MENDONÇA, José Vicente Santos, Direito Constitucional Econômico: A intervenção do Estado na economia à luz da razão pública e do pragmatismo, Rio de Janeiro, 2012, no prelo, página 253. Como anota Carlos Blanco de MORAIS, "[d]os atributos comuns inerentes à subsidiariedade na filosofia teleológica e jurídica, torna-se possível extrair uma ideia difusa de limitação relativa do exercício de poderes das macro comunidades, em favor das comunidades intermediárias que, em razão da sua mais directa proximidade em relação às pessoas, demonstrem ser detentoras de uma maior aptidão na realização adequada e eficaz de certas tarefas." (O Princípio da Subsidiariedade na Ordem Constitucional Portuguesa, in BARROS, Sérgio Resende e ZILVETI, Fernando Aurélio [coords.], Direito Constitucional: estudos em homenagem a Manoel Gonçalves Ferreira Filho, São Paulo: Dialética, 1999, página 32)

${ }^{157}$ Cf. MALDONADO, Carlos Eduardo, Human Rights, Solidarity and Subsidiarity, op. cit., página 81.

${ }^{158}$ Curso de Direito Econômico-Comunitário, Porto Alegre: Síntese, 2001, página 118. 
possuir diversas competências concorrentes e até mesmo de intervenção em seus membros (ou ainda em casos de lacunas) implica na perquirição de limites interventivos. Assim, tanto o próprio Tratado da CCE quanto pelas construções jurisprudenciais, consuma-se afirmar que a intervenção da União Europeia fora de suas competências exclusivas somente é legitima se os objetivos buscados não puderem ser alcançados autonomamente pelos seus membros, ou seja, cuida-se de uma intervenção subsidiária.

Praticamente na mesma linha, é bastante comum falar-se também na subsidiariedade em matéria de federalismo, como uma espécie de sistema de equilíbrio entre as esferas governamentais. Muito ligado ao aspecto institucional a que refere Gaspar Ariño ORTIZ ${ }^{159}$, o vetor de subsidiariedade acaba por informar a própria divisão de competências dos entes federativos, no sentido de garantir a autonomia das esferas inferiores de poder sob um viés de pluralismo político, de sorte que nada deve ser exercido pela estrutura federal mais ampla quando puder igualmente ser exercido pela comunidade local ${ }^{160}$. É que, como diz José Alfredo de Oliveira BARACHO, "[o] dinamismo do federalismo, relacionado com o princípio da subsidiariedade, leva à correlação entre integração e autonomia, criando uma espécie de subsidiariedade de base federativa, capaz de assegurar paz e liberdade dos diversos Estados que fazem parte do processo aproximativo geral, com preservação das potencialidades individuais" $^{161}$.

Em matéria criminal, a subsidiariedade implica no reconhecimento de que a intervenção penal, isto é, a utilização da força estatal para imputar alguém pelo cometimento de delito criminal, somente se mostra admissível quando os demais ramos do direito não conseguirem bem equacionar os conflitos sociais. Segundo apontam os criminalistas, "o princípio da subsidiariedade põe em destaque o fato de que o Direito Penal não é único controle social formal dotado de recursos coativos, embora seja o que disponha, nessa matéria, dos instrumentos mais enérgicos e traumáticos. A gravidade intrínseca desse instrumental, posto à disposição do Direito Penal,

\footnotetext{
${ }^{159}$ Principios de Derecho Público Económico, op. cit., página 111.

${ }^{160}$ Cf. BASTOS, Celso Ribeiro, Curso de Direito Constitucional, 22a ed., São Paulo: Malheiros Editores, 2010, página 223.

${ }^{161}$ O Princípio de Subsidiariedade: conceito e evolução, Rio de Janeiro: Forense, 1997, página 46. No mesmo sentido ver MILLON-DELSOL, Chantal, Le príncipe de subsidiarité, op. cit., página 38.
} 
recomenda, no entanto, que só se faça dele uso quando não tenham tido êxito os meios coativos menos gravosos, de natureza não penal. (...) O princípio da subsidiariedade limita, portanto, o ius puniendi na medida em que só autoriza a intervenção penal se não houver outro tipo de intervenção estatal menos custosa aos direitos individuais" ${ }^{162}$.

Entretanto, anota Luís GRECO que ultimamente tem se verificado alguma tendência doutrinária em questionar a própria premissa da subsidiariedade, isto é, que a intervenção penal seria a mais grave admitida na ciência do direito. Segundo anota, um grupo de estudiosos encabeçados por Klaus Tiedmann vêm afirmando que não só está claro que o direito administrativo e o direito civil podem atingir o cidadão de forma bastante contundente, até mesmo mais severa (por exemplo, com multas exorbitantes, sanções de perda de cargo, proibições de licitar, indenizações, etc.), como também que o direito penal possui muito mais garantias, em especial de ordem processual. Essas críticas receberam respostas, tanto reiterando a gravidade da sanção penal (Volk), quanto demonstrando os riscos para a própria ciência penal ${ }^{163}$. Considerando se tratar de um debate em que todos os interlocutores têm alguma razão, propõe GRECO que o melhor parece ser "redimensionar o princípio da subsidiariedade, tratando a sua premissa básica - 'a sanção penal é sempre a mais grave' - como uma presunção prima facie, afastável em casos concretos", o que resultaria em uma espécie de ônus argumentativo a quem defenda a intervenção penal $^{164}$.

Ainda em matéria penal (não obstante ter sido forjada na teoria geral do direito), fala-se em subsidiariedade no âmbito de normas conflitantes, hipótese em que uma regra teria caráter subsidiário em relação a outra, tida como principal, caso ambas descrevam graus ou fases diversas de violação do mesmo bem jurídico. Assim, a norma penal subsidiária seria absorvida pela principal. Daí a levar o STF a já ter decidido por exemplo que "[o]correndo duas condutas tipificadas como crimes contra o

\footnotetext{
${ }^{162}$ Cf FRANCO, Alberto Silva, Código Penal e sua Interpretação, $8^{\mathrm{a}}$ ed., São Paulo: Revista dos Tribunais, 2007, p. 49.

163 Subsidiariedade (no Direito Penal), in TORRES, Ricardo Lobo et. al (orgs.), Dicionário de Princípios Jurídicos, Rio de Janeiro: Elsevier, 2011, página 1278.

${ }^{164}$ Subsidiariedade (no Direito Penal), op. cit., página 1279.
} 
patrimônio, em que uma é mera sequencia da outra, dirigida ao aproveitamento econômico, ocorre o crime principal, segundo o princípio da subsidiariedade" ${ }^{165}$.

Mas não é só. Há ainda a subsidiariedade em matéria processual, no sentido de critério de admissão de determinadas medidas judiciais. É o caso por exemplo da Ação de Descumprimento de Preceito Fundamental, destinada, como se sabe, a reparar ou evitar dano a preceito fundamental. Nesse sentido, estabelece o artigo $\S 1^{\circ}$ do artigo $4^{\circ}$ da Lei $n^{\circ} 9.882 / 99$ que "[n]ão será admitida argüição de descumprimento de preceito fundamental quando houver qualquer outro meio eficaz de sanar a lesividade". Fala-se aí em um caráter de subsidiariedade da ADPF em relação a outras medidas que consigam cumprir integralmente e de forma eficaz os mesmos objetivos, muito embora essa interpretação tenha sido objeto de contundentes críticas que praticamente neutralizam o mecanismo ${ }^{166}$.

Em matéria de mandado de segurança, é também comum falar de seu caráter subsidiário em relação ao habeas-corpus e ao habeas-data $\left(\mathrm{CF}\right.$, art. $5^{\circ}$, inciso LXIX) ${ }^{167}$, bem como até mesmo em um próprio mandado de segurança subsidiário, nos termos do que estabelece o nos termos do artigo $3^{\circ}$ da Lei $n^{\circ} 12.016 / 09$. É que nesse caso se estabelece a competência de terceiros, igualmente detentores de direitos líquidos e certos, de impetrar a medida na hipótese de seu titular não o fazer em até 30 dias. Surgiria nesse caso um mandado de segurança subsidiário em relação ao detentor principal do direito a ser garantido.

No direito do trabalho a subsidiariedade é mencionada em dois momentos. Primeiro por conta do que estabelece o artigo 769 da CLT, segundo a qual "[n]os casos omissos, o direito processual comum será fonte subsidiária do direito processual do trabalho". Em verdade, está-se aí diante da mera utilização subsidiária de normas gerais e especiais, matéria bem conhecida até dos alunos dos primeiros anos da graduação. Por outro lado, o direito do trabalho se vale também do critério da subsidiariedade como mecanismo de garantia de créditos trabalhistas não adimplidos

\footnotetext{
${ }^{165}$ REsp 112.509/SP, $6^{\text {a }}$ Turma, Rel. Min. Vicente Leal, DJU de 15.06.1998.

${ }^{166}$ Ver nesse sentido, entre diversos outros, MENDES, Gilmar Ferreira, COELHO, Inocêncio Mártires e BRANCO, Paulo Gustavo Gonet, Curso de Direito Constitucional, $4^{\text {a }}$ ed., São Paulo: Saraiva, 2009, páginas 1202-1208; e TAVARES, André Ramos, Curso de Direito Constitucional, $7^{\mathrm{a}}$ ed., São Paulo: Saraiva, 2009, páginas 292-298.

${ }^{167}$ Cf. MORAES, Alexandre de, Direito Constitucional Administrativo, $4^{\text {a }}$ ed., São Paulo: Atlas, 2007, página 303.
} 
pelo devedor principal, chegando ao conceito de responsabilidade subsidiária, que é definida pela doutrina como "uma espécie de benefício de ordem. Não pagando o devedor principal (empresa prestadora de serviços), paga o devedor secundário (a empresa tomadora dos serviços)"168. Encontra-se previsto expressamente no Enunciado 331 do TST.

Bem é verdade que a responsabilidade subsidiária não é exclusividade do direito trabalhista. Pelo contrário, trata-se também de figura integrante da teoria geral do direito, aparecendo expressamente em seara civil (contrato de fiança - arts. 818 e ss. do Código Civil) e tributária (CTN, art. 133, II). Mas como também é sabido, o tema é recorrente no direito administrativo. Nesse sentido, afirma-nos Celso Antônio BANDEIRA DE MELLO que existe responsabilidade subsidiária da Administração Pública nos casos em que, havendo a concessão de determinado serviço público à iniciativa privada e, após prática de ato danoso esta mesma concessionária apresenta situação de insolvência, resultando na impossibilidade de arcar com suas obrigações. Estar-se-ia, em sua opinião, diante da responsabilidade subsidiária do Poder Público de arcar com a indenização dos danos causados pelo concessionário solvente ${ }^{169}$.

Mas há ainda outro exemplo de responsabilidade subsidiária relativa ao direito administrativo. Trata-se da previsão expressa contida no inciso I do $\S 2^{\circ}$ do artigo 13 da Lei $n^{\circ}$ 11.107/05, que cuida das contratações de consórcios públicos no Brasil. Referido dispositivo estabelece figurar como um dos requisitos essenciais do contrato de programa que implique na transferência de encargos, serviços, pessoal e bens entre os entes consorciados a existência de cláusula que preveja "os encargos transferidos e a responsabilidade subsidiária da entidade que os transferiu". Assim, determina a Lei que o ente que transferiu determinado encargo se declare subsidiariamente responsável por eventuais danos causados pelo ente que o recebeu.

Não obstante, até mesmo em matéria de direitos fundamentais e sociais a vertente da subsidiariedade tem sido destacada. Com efeito, tem-se discutido

\footnotetext{
${ }^{168}$ MARTINS, Sérgio Pinto, A Terceirização e o Direito do Trabalho, São Paulo: Atlas, 2009, página 137.

${ }^{169}$ Curso de Direito Administrativo, 29a ed., São Paulo: Malheiros Editores, 2012, página 773. Em sentido contrário, isto é, defendendo que haveria no caso responsabilidade solidária da Administração em função de ato praticado pelo concessionário fundada na equiparação do serviço público às relações de consumo e do usuário ao consumidor, ver TEPEDINO, Gustavo, Evolução da Responsabilidade Civil no Direito Brasileiro e suas Controvérsias na Atividade Estatal, in Temas de Direito Civil, $4^{\mathrm{a}}$ ed., Rio de Janeiro: Renovar, 2008, páginas 201-227.
} 
atualmente, como limite jurídico à eficácia de direitos fundamentais e sociais, a ideia de subsidiariedade pautada pelo vetor da primazia da auto-responsabilidade ${ }^{170}$. É o processo de "autopoiesis de subsidiariedade" mencionado por CANOTILHO ${ }^{171}$, que busca justamente uma adequada distribuição dos encargos de efetivação de direitos sociais entre Estado e sociedade. Há aqui dois focos em jogo: de um lado, exige-se o efetivo exercício da autonomia dos particulares e de uma corresponsabilidade social na efetivação de seus direitos; de outro, acaba-se limitando em alguma medida as demandas administrativas por direitos sociais econômicos, como a saúde por exemplo ${ }^{172}$.

Enfim, como se pode perceber, a utilização da subsidiariedade como critério de dimensionamento entre dois elementos, sejam eles competências, entes federativos, instituições, normas, agrupamentos sociais, etc., é muitíssimo ampla e totalmente recorrente no mundo jurídico. Diversas são as hipóteses em que se recorre a esse mecanismo como forma de conformação e delimitação. Para o contexto do presente trabalho, entretanto, o que nos interessa mesmo é a subsidiariedade como vetor de limitação à intervenção estatal no domínio econômico, mais precisamente na regulação econômica. Buscamos aqui analisar e defender que há sim um vetor de subsidiariedade da regulação administrativa da economia, que deve ter como parâmetro a eventual e objetivamente verificada autossuficiência agentes econômicos em garantir o atingimento de determinada pauta de interesse público. Ou seja, se determinado setor econômico está andando bem por conta própria, seja do ponto de vista interno ou

${ }^{170}$ Cf. NEUNER, Jörg, Los Derechos Humanos Sociales, in Anuario Iberoamericano de Justicia Constitucional, $\mathrm{n}^{\circ}$ 15, Madrid: Centro de Estudios Políticos y Constitucionales, jan/dez 2011, páginas 254-255 - tradução livre: "O princípio da subsidiariedade contém, segundo a acepção subsidium e também segundo seu contexto histórico-ideológico, um mandado 'positivo' de ajuda. Ao mesmo tempo, em sua variante significativa 'negativa' significa que o Estado tem de observar a peculiaridade das unidades sociais inferiores e não pode atrair a si as competências originais daquelas. Esse limite de intervenção garante, por seu turno, um espaço livre para uma atuação autodeterminada, mas por outra parte também fundamenta uma 'primazia da autorresponsabilidade'. Portanto, remete-se ao indivíduo primariamente o dever de velar por si e por sua família."

171 "Metodologia Fuzzy" e "Camaleões Normativos" na Problemática Actual dos Direitos Económicos, Sociais e Culturais, in Estudos sobre Direitos Fundamentais, São Paulo: Revista dos Tribunais, 2008, páginas 111-113.

${ }^{172}$ Cf. SARLET, Ingo Wolfgang e FIGUEIREDO, Mariana Filchtiner, Reserva do Possível, Mínimo Existências e Direito à Saúde: algumas aproximações, in SARLET, Ingo Wolfgang e TIMM, Luciano Benetti (orgs.), Direitos Fundamentais: orçamento e "reserva do possível", Porto Alegre: Livraria do Advogado, 2008, página 36. 
mesmo externo ao próprio mercado, absolutamente despicienda se mostraria a intervenção estatal.

A bem da verdade, a subsidiariedade como limite à intervenção estatal na economia (seja regulatória ou não) tem sido afirmada há muitos anos pela doutrina ${ }^{173}$. Até o momento, portanto, nada de novo está sendo apresentado.

\section{III.3. Nota conceitual: subsidiariedade como regra ou como princípio?}

Antes de dar continuidade e adentrarmos às críticas e aos fundamentos da subsidiariedade como limite à regulação econômica, cabe aqui uma nota conceitual. Praticamente toda a doutrina aborda a subsidiariedade como um princípio, o famoso princípio da subsidiariedade. Poderíamos aqui tranquilamente repetir esse conceito já tão consagrado se não fosse por uma reflexão de ordem teórica mas que para nós é indesviável.

\footnotetext{
${ }^{173}$ A lista de autores que assim pensam é bastante extensa, ainda que com especificidades, fundamentos distintos e enorme variação de intensidade na argumentação. No direito brasileiro confira-se: MARQUES NETO, Floriano de Azevedo, Limites à Abrangência e à Intensidade da Regulação Estatal, op. cit., páginas 79-84; VILLELA SOUTO, Marcos Juruena, Direito Administrativo Regulatório, op. cit., páginas 34-38; MOREIRA NETO, Diogo de Figueiredo, Curso de Direito Administrativo, op. cit., páginas 95-97; TAVARES, André Ramos, Direito Constitucional Econômico, São Paulo: Método, 2003, páginas 279-281; TATSCH, Simone, Princípio da Subsidiariedade: deveres de abstenção e de atuação na atividade econômica, Tese (Doutorado em Direito Econômico) - FADUSP, 2005; GONÇALVES, Marcos Peixoto Mello, Direito e Economia: Democracia Política e Economia, São Paulo: Quartier Latin, 2009, páginas 136-154; TÁCITO, Caio, A Reforma do Estado e a Modernidade Administrativa, in Temas de Direito Público (Estudos e Pareceres), $3^{\circ}$ vol., Rio de Janeiro: Renovar, 2002, páginas 41-50; FERREIRA FILHO, Manoel Gonçalves, Curso de Direito Constitucional, $35^{\mathrm{a}}$ ed., São Paulo: Saraiva, 2009, páginas 358-363; TORRES, Silvia Faber, O Princípio da Subsidiariedade no Direito Público Contemporâneo, Rio de Janeiro: Renovar, 2001, páginas 152-159; JUSTEN FILHO, Marçal, Curso de Direito Administrativo, op. cit., página 808; CYRINO, André Rodrigues, Direito Constitucional Regulatório, Rio de Janeiro: Renovar, 2010, páginas 52-67; ARAGÃO, Alexandre Santos de, Agências Reguladoras e a Evolução do Direito Administrativo Econômico, op. cit., páginas 132-134; GUERRA, Sérgio, Introdução às Agências Reguladoras, Rio de Janeiro: Freitas Bastos, 2004, páginas 6-7; MOREIRA, Egon Bockmann, O Direito Administrativo da Economia, a Ponderação de Interesses e o Paradigma da Intervenção Sensata, op. cit., páginas 53-98; TOLEDO, Gastão Alves de, O Direito Constitucional Econômico e sua Eficácia, Rio de Janeiro: Renovar, 2004, páginas 174-177; LOSS, Giovani Ribeiro, A Regulação Setorial do Gás Natural, Belo Horizonte: Fórum, 2007, páginas 44-45. Já no direito estrangeiro ver: ORTIZ, Gaspar Ariño, Principios de Derecho Público Económico, op. cit., páginas 111-117; MOREIRA, Vital, Auto-Regulação Profissional e Administração Pública, op. cit. páginas 97-99; OTERO, Paulo, Vinculação e Liberdade de Conformação Jurídica do Sector Empresarial do Estado, Coimbra: Coimbra Editora, 1998, páginas 23-55; D’ALTE, Sofia Tomé, A Nova Configuração do Sector Empresarial do Estado e a Empresarialização dos Serviços Públicos, Coimbra: Almedina, 2007, páginas 66-76; MARTINS, Margarida Salema d'Oliveira, O Princípio da Subsidiariedade em Perspectiva Jurídico-Política, op. cit., em especial páginas 82-88; TOSATO, Egidio, Persona, Società Intermedie e Stato, Milão: Giuffrè, 1989, páginas 85-101.
} 
Como já tivemos a oportunidade de demonstrar, a definição do que seja um princípio jurídico é bastante elástica e varia de acordo com a teoria que se adota. Nesse sentido, utilizar uma ou outro conceito configura atividade das mais relevantes e que suplanta a mera preferência doutrinária, sendo que caso se pretenda tratar o tema com seriedade e coerência, deve-se ter em mente as consequências de chamar determinada norma de regra ou princípio. Em outras palavras, falar em princípio da subsidiariedade implica em adotar determinada concepção do que seja um princípio jurídico, o que reflete a adoção de determinada teoria. É esse o ponto que se pretende analisar no presente tópico, ainda que brevemente ${ }^{174}$.

Com efeito, é sabido que conceituar os princípios talvez seja um dos maiores desafios do direito contemporâneo ${ }^{175}$. É também livre de dúvidas que em termos de importância, a grande virada dos princípios para a teoria do direito parece ter sido o reconhecimento de sua capacidade normativa, isto é, a partir do momento em que se percebeu que os princípios também possuíam poder de ordenação social por conta da obrigatoriedade de observância de seus comandos ${ }^{176}$. Daí a dúvida sobre qual seria a diferença entre princípios e regras, já que ambos são dotados de capacidade normativa.

Embora seja certa a existência de tantas teorias quanto autores que se propuseram a tratar do tema, duas macro fórmulas acabam se sobressaindo. São elas: $(\boldsymbol{i})$ a teoria que diferencia as normas pelo grau e (ii) a teoria que as diferencia pela sua forma de aplicação.

A diferenciação entre regras e princípios pelo grau das normas é certamente a tese mais difundida pela doutrina brasileira ${ }^{177}$. Trata-se simplesmente de dizer que o grau de generalidade, abstração ou de fundamentalidade dos princípios é

\footnotetext{
${ }^{174}$ Sobre o tema ver nosso Conceito de princípio jurídico e seus impactos no Direito Público contemporâneo: o caso da dispensa de licitação lastreada no inciso XIII do artigo 24 da Lei $n^{\circ}$ 8.666/93, in Revista de Direito Administrativo e Constitucional, ano 11, n ${ }^{\circ} 43$, Belo Horizonte: Fórum, jan/mar 2011, páginas 167-196.

${ }^{175}$ Como observa Luis Prieto SANCHÍs, "[n]em na linguagem do legislador, nem na dos juízes, nem da teoria do Direito existe um emprego minimamente uniforme da expressão 'princípios', tanto assim que, recordando a terminologia de Hart, cabe dizer que aqui a 'zona de penumbra'resulta mais ampla que o 'núcleo de certeza'." (Ley, Princípios, Derechos, Madrid: Editorial Dykinson, 1998, páginas 48-49 tradução livre)

${ }^{176}$ Sobre o tema, ver por todos BOBBIO, Norberto, Teoria do Ordenamento Jurídico, 6 a ed., Brasília: Universidade de Brasília, 1995, páginas 158-159.
}

${ }^{177}$ Cf. SILVA, Virgílio Afonso, Princípios e Regras: mitos e equívocos acerca de uma distinção, in Revista Latino-Americana de Estudos Constitucionais, v. 1, São Paulo: Del Rey, jan/jun 2003, página 609. 
muito mais amplo do que nas regras ${ }^{178}$. Perfeito exemplo dessa concepção é a definição de princípio dada por Celso Antônio BANDEIRA DE MELLO, para quem trata-se de “mandamento nuclear de um sistema, verdadeiro alicerce dele, disposição fundamental que se irradia sobre diferentes normas compondo-lhe o espírito e servindo de critério para sua exata compreensão e inteligência, exatamente por definir a lógica e a racionalidade do sistema normativo, no que lhe confere a tônica e lhe dá sentido harmônico. É o conhecimento dos princípios que preside a intelecção das diferentes partes componentes do todo unitário que há por nome sistema jurídico positivo" ${ }^{\text {"179. }}$.

Já a outra forma de diferenciar os princípios das regras tem como vetor uma matriz qualitativa, em que a distinção se encontra no modo de aplicação das normas, isto é, em sua estrutura normativa. Os maiores expoentes dessa teoria são certamente Ronald DWORKIN e Robert ALEXY, referências tão conhecidas quanto indesviáveis. Para DWORKIN, a diferença básica reside no fato de que, enquanto as regras são aplicadas ao estilo do tudo-ou-nada (presentes os requisitos, ou são válidas e aplicáveis ou não são válidas e por isso não são aplicáveis), os princípios possuem também a dimensão do peso ou da importância, de modo que devem ser sempre cotejados e ponderados nas decisões ${ }^{180}$. Já para Robert ALEXY, “o ponto decisivo da distinção entre regras e princípios é que princípios são normas que ordenam que algo seja realizado na maior medida possível dentro das possibilidades jurídicas e fáticas existentes" ${ }^{181}$. Segundo ALEXY, os princípios configuram mandamentos de otimização, já que podem ser satisfeitos em vários graus a depender das condições fáticas e jurídicas existentes no caso prático, ao passo que as regras configuram um tipo normativo em que ou as possibilidades são satisfeitas ou não são, contendo, portanto, determinações no âmbito daquilo que é possível fática e juridicamente ${ }^{182}$.

\footnotetext{
${ }^{178}$ Sobre o maior grau de generalidade dos princípios ver RAZ, Joseph, Razão Prática e Normas, Rio de Janeiro: Elsevier, 2010, página 43. Para uma defesa do maior grau de abstração e generalidade dos princípios conferir CANOTILHO, Joaquim José Gomes, Direito Constitucional e Teoria da Constituição, op. cit., página 1160, para quem "os princípios são normas com um grau de abcstração relativamente elevado; de modo diverso, as regras possuem uma abstração relativamente reduzida". É também CANOTILHO quem observa que "os princípios são normas de natureza estruturante ou com um papel fundamental no ordenamento jurídico devido à sua posição hierárquica no sistema das fontes".

${ }^{179}$ Curso de Direito Administrativo, op. cit., páginas 974-975.

${ }^{180}$ Taking Rights Seriously, Massachusetts: Harvard University Press, 1978, páginas 22-28.

${ }^{181}$ Teoria dos Direitos Fundamentais, São Paulo: Malheiros Editores, 2008, página 90.

182 Teoria dos Direitos Fundamentais, op. cit., páginas 90-91.
} 
Assim, é fácil ver que essas duas formas de analisar o tema não são coincidentes ou intercambiáveis. Isto é, não se pode utilizar concomitantemente as teorias que distinguem as normas pelo grau (seja de generalidade, fundamentalidade ou abstração) e pela forma de aplicação. Não é possível dizer, por exemplo, que os princípios são normas de maior grau de generalidade que as regras e que possuem estrutura normativa de mandamentos de otimização. Ou se adota um critério ou outro ${ }^{183}$.

Dito isso, e voltando ao tema central do presente trabalho, parece coerente afirmar que a subsidiariedade figura como princípio em uma teoria e como regra em outra. Explica-se.

De um lado, para a teoria que classifica as normas de acordo com o grau de generalidade, abstração ou fundamentalidade, a subsidiariedade é um princípio. Isso porque parece certamente se tratar de um "mandamento nuclear" do sistema jurídico, uma verdadeira norma fundamental que contribui para a completa interpretação de todo o ordenamento, um dos principais elementos de equacionamento entre o espaço público e o espaço privado, um critério elementar de organização federativa. Nesse caso, a subsidiariedade possuiria um grau de generalidade, abstração e fundamentalidade muitíssimo maior que uma mera regra, elevando-a ao patamar de um verdadeiro princípio jurídico. É justamente neste contexto que praticamente toda a doutrina trata do tema à luz do princípio da subsidiariedade.

Por outro lado, tendo em vista a teoria que distingue as normas a partir do seu modo de aplicação (estrutura normativa), a subsidiariedade configura claramente uma regra. Ora, bastante evidente que sua aplicação não dá espaço para ponderações: deve-se respeitar a atuação dos particulares, mediante a qual somente a partir da verificação de sua incapacidade em implementar valores considerados de interesse público é que a intervenção estatal se legitimaria. Não há como se admitir em alguns casos que a intervenção estatal ignore eventual autossuficiência dos corpos

\footnotetext{
${ }^{183}$ Cf. nosso Conceito de princípio jurídico e seus impactos no Direito Público contemporâneo, op. cit., páginas 183-187. Como bem observa Virgílio Afonso da SILVA, “[o] conceito de princípio, na teoria de Alexy, é um conceito que nada diz sobre a fundamentalidade da norma. Assim, um princípio pode ser um 'mandamento nuclear do sistema', mas pode também não o ser, já que uma norma é um princípio apenas em razão de sua estrutura normativa e não de sua fundamentalidade. (...) Muito do que as classificações tradicionais chamam de princípio, deveria ser, se seguirmos a forma de distinção proposta por Alexy, chamado de regra. Assim, falar em princípio do nulla poena sine lege, em princípio da legalidade, em princípio da anterioridade, entre outros, só faz sentido para as teorias tradicionais. Se se adotam os critérios propostos por Alexy, essas normas são regras, não princípios" (Princípios e Regras: mitos e equívocos acerca de uma distinção, op. cit., página 613).
} 
privados. Não há pois como se fazer e sopesamentos aqui, não há como se aplicar a subsidiariedade em graus: ou ela é cumprida ou não. O comando da subsidiariedade, portanto, somente pode ser cumprido no todo, nunca em partes.

De nossa parte, embora nutramos significativa preferência pelo critério de diferenciação baseado na estrutura normativa das regras ${ }^{184}$ - o que implicaria tratar a subsidiariedade como uma regra -, fato é que não se pode negar a influência da utilização do termo 'princípio da subsidiariedade'. Ainda que compreendamos que se trata de "tarefa do intérprete definir se a norma, produto da interpretação, é uma regra ou um princípio" ${ }^{185}$, não se pode pretender que termos tão consagrados sejam simplesmente abandonados pela doutrina. Igualmente faria pouco sentido esperar que a impessoalidade, a ilegalidade, a proporcionalidade, a razoabilidade, a anterioridade tributária, a retroatividade penal mais benéfica, etc., fossem tratados como regras de uma hora para outra apenas pela adoção de determinada teoria, forjada, a bem da verdade, em países estrangeiros ${ }^{186}$.

\footnotetext{
${ }^{184}$ Conforme já tivemos a oportunidade de expor, "[a] teoria que diferencia as normas pelo grau de generalidade, abstração ou fundamentalidade, a despeito de sua consagração na prática jurídica, leva consigo o problema da instabilidade e da insegurança jurídica por conta da estruturação de um ordenamento que coloca os princípios como normas mais importantes e que, portanto, norteiam a interpretação de todo o resto. E como os princípios são normas fundamentais do sistema, sua identificação no texto constitucional ou no ordenamento pode ser livremente delegada ao aplicador do Direito. Com isto, outorga-se ao interprete até mesmo a irresistível liberdade para identificar um valor no texto e, a partir disto, criar uma norma passível de suplantar uma regra legal. Pelo menos está tem sido a alternativa de grande parte da doutrina e da jurisprudência que se ocupa do Direito Público. (...) Já a teoria qualitativa, que defende a distinção das normas pela sua estrutura, não padece desse mal. Ao estatuir que as regras são comandos definitivos (ou incidem e devem ser aplicadas, ou não incidem, devendo ou ser excluídas do ordenamento ou receber uma cláusula de exceção) e os princípios normas que predicam que algo deva ser realizado na maior medida possivel, cria-se um parâmetro claro do que seja cada uma delas e de qual sua verdadeira função. A opção de identificar categorias normativas implícitas no ordenamento, embora igualmente admitida, encontra óbices plenamente controláveis. Isso sem contar a impossibilidade de se conceber a supressão de regras pela aplicação de princípios por ofensa à segurança jurídica e por negação à competência constitucional do Legislativo em definir opções político-majoritárias legítimas." (Conceito de princípio jurídico e seus impactos no Direito Público contemporâneo, op. cit., páginas 191-192)
}

${ }^{185}$ Cf. SILVA, Virgílio Afonso da, Direitos Fundamentais: conteúdo essencial, restrições e eficácia, São Paulo: Malheiros Editores, 2009, página 57.

${ }^{186}$ Como também anota Virgílio Afonso da SILVA, "[n]ão há como querer, por exemplo, que expressões como 'princípio da anterioridade' ou princípio da legalidade' sejam abandonadas, pois, quando se trata de palavras de forte carga semântica, como é o caso do termo 'princípio', qualquer tentativa de uniformidade terminológica esta fadada ao insucesso. Mais importante do que a ingênua ambição de querer uniformizar a utilização do termo 'princípio' é deixar claro que ele, na expressão 'princípio da proporcionalidade', não tem o mesmo significado de 'princípio" na distinção entre regras e princípios, na acepção da teoria de Robert Alexy." (O Proporcional e o Razoável, in Revista dos Tribunais, vol. 798, São Paulo: Revista dos Tribunais, abr/2002, página 26) 
Portanto, ao invés de entabular uma disputa conceitual ou um racha doutrinário, mais interessante parece encontrar o fundamento constitucional da subsidiariedade e compreender de que forma tal norma deve ser aplicada. Daí nossa opção de tratar do tema simplesmente como subsidiariedade, sem classificar a norma como regra ou princípio, o que, a bem da verdade, somente contribuiria para confundir o trabalho.

\section{III.4. As críticas contemporâneas ao vetor de subsidiariedade}

Como dissemos algumas linhas acima, a subsidiariedade como limite à intervenção estatal na economia (seja regulatória ou não) tem sido afirmada há anos pela doutrina brasileira e também estrangeira. Entretanto, críticos também existem. É que os limites da intervenção estatal configura tema que logicamente desperta embates ideológicos acirrados. Dizer que há uma preferência da atuação privada na economia em face da atuação estatal leva alguns a equivocamente associar a questão ao liberalismo econômico ou até mesmo ao impopular neoliberalismo, teorias que tiveram seus momentos mas que já estão em alguma medida ultrapassadas, conforme também já visto.

De todo modo, parece-nos ser justamente por conta desses desvios que começaram a surgir mais recentemente trabalhos acadêmicos criticando contundentemente a ideia de subsidiariedade como condutora ou ao menos incidente na relação indivíduo/Estado/economia.

Uma dessas linhas críticas focou no argumento da neutralidade da Constituição Federal de 1988 em relação ao intervencionismo estatal. É dizer, para os autores que seguem esse raciocínio, tentar extrair de uma carta compromissória, imparcial e abrangente como o Texto de 1988 alguma diretriz sobre ativismo ou abstenção estatal no campo econômico significaria tentar capturá-lo ideologicamente. Essa é a opinião de Cláudio Pereira de SOUZA NETO e de José Vicente Santos de MENDONÇA, para quem "[n] interpretação constitucional da livre iniciativa, não se deve atribuir conteúdo ao princípio com base em doutrinas liberais abrangentes de institucionalização do laissez faire", de onde extraem a conclusão de que "[o] princípio da subsidiariedade econômica não possui status constitucional, pois a Constituição da 
República (...) prevê amplas possibilidades de intervenção do Estado na esfera econômica" ${ }^{\prime 187}$.

Indo mais além, o mesmo José Vicente Santos de MENDONÇA, em outro texto, vale-se da teoria da pragmatismo jurídico de Posner, MacCormick e Aarnio, bem como na teoria da razão pública de John Rawls, para defender que a subsidiariedade é, no máximo, uma diretriz política-administrativa do Estado, sem qualquer fundamento jurídico ou constitucional. Nesse sentido, sua aplicação ao tema da intervenção estatal na economia configuraria opção ideológica irrazoável e extrema, devendo, portanto, ser excluída do debate político (ainda que possa fazer parte legítima do debate social $)^{188}$. Para MENDONÇA, a subsidiariedade é representativa da ideologia econômico-liberal e, portanto, antítese do liberalismo e cerceadora da autonomia privada do indivíduo, já que predicaria sempre menos Estado, limitando eventuais necessidades privadas de maior presença estatal ${ }^{189}$. Assim, acaso constitucionalizada, a subsidiariedade inadmitiria intervenção estatal econômica mais intensa ${ }^{190}$.

Outra linha de argumentação defende que a livre iniciativa, além de não ser um direito fundamental, deve ser relativizada e exercida com base em fins e objetivos coletivos e sociais (argumento este que não destoa da maioria dos autores que defendem a subsidiariedade da atuação estatal). Segundo Gilberto BERCOVICI, “[a] iniciativa econômica pública não pode impedir a iniciativa econômica privada, nem a iniciativa econômica privada pode bloquear a iniciativa econômica pública Esta compatibilidade entre iniciativa econômica pública e iniciativa econômica privada também não significa equilíbrio. A Constituição legitima a atuação do Estado na economia, não existindo fronteiras espaciais ou temporais para esta atuação. $O$ tamanho, abrangência e profundidade da atuação do Estado no domínio econômico é uma decisão política, que varia de acordo com o momento histórico" ${ }^{\text {"191 }}$. Para este autor,

187 Fundamentalização e Fundamentalismo na Interpretação do Princípio Constitucional da Livre Iniciativa, in SOUZA NETO, Cláudio Pereira e SARMENTO, Daniel, A Constitucionalização do Direito, Rio de Janeiro: Lumen Juris, 2007, página 731.

${ }^{188}$ Direito Constitucional Econômico: A intervenção do Estado na economia à luz da razão pública e do pragmatismo, op. cit., páginas 252-275.

${ }^{189}$ Direito Constitucional Econômico, op. cit., páginas 258-260.

${ }^{190}$ Direito Constitucional Econômico, op. cit., páginas 264.

${ }^{191}$ Direito Econômico do Petróleo e dos Recursos Minerais, op. cit., página 272. No mesmo sentido, ver BERCOVICI, Gilberto, Os Princípios Estruturantes e o Papel do Estado, in CARDOSO JR, José 
portanto, há ampla discricionariedade do Poder Público para onde, quando e quanto intervir na economia, sem qualquer parâmetro constitucional ou mesmo jurídico a respeito.

Por outro lado, mas não destoando dos demais, Emerson GABARDO defende que "é o interesse público, e não a subsidiariedade, o fundamento de respaldo da norma constitucional interventiva. (...) Quando se tem o desenvolvimento tanto como um direito fundamental dos indivíduos, quanto como um objetivo ou política pública obrigatória (como no caso do Brasil), não há como se esperar do Poder Público posicionar-se como se fosse uma instância secundária e suplementar" ${ }^{192}$. Para GABARDO, estando presente o interesse público identificado pelos representantes eleitos (dentro das concepções discricionárias que o próprio conceito admite), deverá haver intervenção estatal primária; de outro lado, não se verificando interesse algum, o Estado estará expressamente proibido de intervir.

\section{III.4.1. Insubsistência das críticas e afirmação da subsidiariedade como vetor de restrição interventiva estatal no domínio econômico}

Não obstante a contundência dessas críticas, algumas notas são necessárias para apontar equívocos que acabam comprometendo cada um dos argumentos utilizados. Mas antes de adentrarmos ao mérito de cada crítica delineada, uma nota se faz importante.

III.4.1.a. Um debate que reproduz em grande parte as discussões travadas em Portugal após a revisão constitucional de 1982

Todos os argumentos apresentados pelos autores que negam a existência de um vetor de subsidiariedade como limite à intervenção do Estado na economia são certamente relevantes e merecem ser devidamente considerados no debate. Entretanto, é curioso observar que, embora adaptada ao contexto brasileiro, não

Celso (org.), A Constituição Brasileira de 1988 Revisitada: recuperação histórica e desafios atuais das políticas públicas nas áreas econômica e social, Vol. 1, Brasília: IPEA, 2009, páginas 255-291.

${ }^{192}$ Interesse Público e Subsidiariedade, Belo Horizonte: Fórum, 2009, páginas 229-230. 
se trata de discussão inteiramente nova. Ao contrário, parece se tratar de uma espécie de réplica dos debates que tomaram lugar em Portugal após o processo de desideologização do caráter marxista da Constituição de 1976, operada em $1982^{193}$.

Como se sabe, o texto original da Constituição Portuguesa de 1976, para além de meros compromissos sociais, propugnava efetivamente a "transição para o socialismo mediante a criação de condições para o exercício democrático do poder pelas classes trabalhadoras" (art. $2^{\circ}$ ), objetivando a construção de uma "sociedade sem classes" (art. $\left.1^{\circ}\right)$. Configurava tarefa explícita do Estado "[s]ocializar os meios de produção e a riqueza" e "abolir a exploração e a opressão do homem pelo homem" (art. $\left.9^{\circ}, c\right)$, mediante a "a apropriação colectiva dos principais meios de produção", a qual era considerada pelo próprio Texto como um instrumento para "o desenvolvimento pacífico do processo revolucionário" (art. 10). De todo modo, sem embargo dos avanços em matérias de direitos fundamentais e sociais, e não desconhecendo o contexto político-social em que foi produzida ${ }^{194}$, é fato que a Constituição Portuguesa de 1976 continha um plano de regime socialista explícito, bastante harmonizado com a ideologia marxista.

Em 1982 foi realizada a primeira revisão constitucional ordinária do Texto, no qual destaca-se o que António L. de SOUSA FRANCO chamou de "desideologização ou desdogmatização" de seu conteúdo ${ }^{195}$. Em verdade, ao invés de programar a transição para o socialismo, o novo texto buscava apenas a democracia econômica, social e cultural do povo português, bem como o aprofundamento da democracia participativa. Foram omitidas as menções à revolução e ao processo revolucionário, sumiram as referências ao socialismo, diminuíram drasticamente as alusões à socialização, tornou-se menos frequente e mais restrita a ideia de apropriação coletiva dos meios de produção (passou a figurar como "apropriação colectiva dos principais meios de produção, solos e recursos naturais"), desaparecem os termos com conotação explicitamente marxista como 'poder democrático dos trabalhadores',

\footnotetext{
${ }^{193}$ Cf. OTERO, Paulo, Vinculação e Liberdade de Conformação Jurídica do Sector Empresarial do Estado, op. cit., páginas 31-33.

${ }^{194}$ Para um visão bastante detalhada do processo de elaboração da Constituição Portuguesa de 1976, justificando em grande medida as opções políticas adotadas, ver OLIVEIRA, Fábio Corrêa Souza de, Morte e Vida da Constituição Dirigente, Rio de Janeiro: Lumen Juris, 2010, páginas 173-181.
}

195 A Revisão da Constituição Económica, in Revista da Ordem dos Advogados, ano 42, Vol. III, Lisboa: Ordem dos Advogados, set/dez 1982, página 614. 
'relações de produção' e 'forças produtivas', etc ${ }^{196}$. Em suma, a revisão de 1982 conferiu à Constituição Portuguesa um caráter ideologicamente mais neutro, não constituindo mais uma opção por um modelo político-econômico especificamente socialista $^{197}$.

Pois mesmo após esse processo de transição, continuava parte da doutrina portuguesa a propugnar a inexistência de um critério de subsidiariedade a subordinar a intervenção estatal na economia. Interessa-nos, entretanto, os argumentos utilizados nesse debate.

Nesse sentido, duas vertentes argumentativas se alinhavam. Uma primeira defendendo a livre atuação do Estado em seara econômica, sem qualquer restrições ou condicionamentos, aos moldes do que predicam parte dos críticos brasileiros da subsidiariedade no Brasil. Já o segundo argumento tem como mote o fato de haver a possibilidade de o Estado poder utilizar as empresas privadas como instrumento de sua política econômica, seja impondo obrigações de fazer ou então indo ao extremo de excluir a livre gestão privada e anulando o conteúdo econômico ${ }^{198}$. Segundo anota Paulo OTERO:

"Em síntese, a ausência de consagração do princípio da subsidiariedade do Estado na versão da Constituição resultante da revisão de 1982 radicava no caráter duplamente livre da iniciativa económica pública: (i) livre na imposição de limites qualitativos e quantitativos à iniciativa económica privada e, por outro lado, (ii) livre também na escolha do âmbito da actividade económica que desenvolve directamente."199

Portanto, bem de ver que a discussão atual sobre a existência da subsidiariedade como limite à intervenção estatal da Economia no Brasil utiliza em grande medida os argumentos que tomaram lugar na revisão da Constituição Portuguesa de 1976, realizada em 1982. Aqui, como lá, se propugna um livre espaço de intervenção

\footnotetext{
${ }^{196}$ Cf. SOUSA FRANCO, António S., A Revisão da Constituição Económica, op. cit., páginas 614-616.

${ }^{197}$ Cf. MONDACA, Luís S. Cabral de, Direito Económico, op. cit., página 152.

${ }^{198}$ Cf. a esse respeito MONCADA, Luis S. Cabral de, Direito Económico, op. cit., páginas 191-195; CANOTILHO, José Joaquim Gomes e MOREIRA, Vital, Constituição da República Portuguesa Anotada e Comentada, $3^{\text {a }}$ ed., Lisboa: Coimbra Editora, 1993, páginas 387-389

${ }^{199}$ Vinculação e Liberdade de Conformação Jurídica do Sector Empresarial do Estado, op. cit., página 33.
} 
estatal, como se se tratasse de um verdadeiro direito estatal. Sobre o contexto português, fala-se ainda em ausência de limites quantitativos ou qualitativos na intervenção, o que traduz uma opinião de livre regulação sobre qualquer assunto e em qualquer intensidade, o que é corolário de uma concepção que não enxerga limites da atuação estatal.

Dito isto, tentaremos abaixo apresentar algumas falhas que acabam comprometendo as próprias críticas acima sumariadas.

\section{III.4.1.b. Críticas baseadas em uma visão caricata da subsidiariedade}

Em primeiro lugar, é fácil perceber que a conclusão dos autores brasileiros que constroem críticas à subsidiariedade como vetor de restrição à intervenção estatal na economia (regulatória ou não) reside em algumas ideias distorcidas. A primeira e provavelmente a principal delas implica em uma visão bastante caricata do que seja a subsidiariedade da atuação estatal no domínio econômico, algo como se a livre iniciativa fosse um valor absoluto, imponderável, e que pudesse ser exercido independentemente dos objetivos constitucionais e alheio às pautas desenvolvimentistas mais relevantes.

E é fácil verificar isso. Gilberto BERCOVICI, por exemplo, ao criticar a utilização da subsidiariedade como vetor de limitação à regulação econômica, alega que os autores que assim defendem partem do pressuposto de que a atividade regulatória somente poderia ser utilizada para expandir as atividades do setor privado, nunca para restringi-las, já que estaria limitada pela livre iniciativa. E conclui dizendo que, "[a]final, qualquer cerceamento da livre iniciativa seria inconstitucional" ${ }^{200}$. No mesmo sentido, José Vicente Santos de MENDONÇA aponta, conforme mencionamos acima, que a subsidiariedade, acaso constitucionalizada, transformar-se-ia em vedação a uma maior intervenção estatal, sob pena de se incorrer em inconstitucionalidade. Em outras palavras, para o referido autor, a subsidiariedade funciona como um limite absoluto à intervenções mais profundas na economia ${ }^{201}$.

\footnotetext{
${ }^{200}$ Direito Econômico do Petróleo e dos Recursos Minerais, op. cit., páginas 283-284.

${ }^{201}$ Direito Constitucional Econômico: A intervenção do Estado na economia à luz da razão pública e do pragmatismo, op. cit., página 259.
} 
De nossa parte, não compartilhamos logicamente desse entendimento. Em verdade, parece equivocado associar a subsidiariedade a algum tipo de absenteísmo ou um dever de não intervenção. Ora, praticamente todos os autores que tratam da subsidiariedade como limite à intervenção estatal no domínio econômico, mormente a regulatória, expressamente declaram que a livre iniciativa não é um direito absoluto, muito ao contrário, deve ser confrontada com os objetivos inscritos na Constituição Federal $^{202}$. Gaspar Ariño ORTIZ, um dos autores mais criticados e sempre citado como um defensor voraz da livre iniciativa, discorre longamente sobre a relação entre a liberdade individual, a subsidiariedade estatal, a igualdade de todos os indivíduos e a solidariedade social, deixando vincado o dever público do Estado intervir na economia para (i) garantir a segurança e estabilidade jurídica do mercado, (ii) ordenar e estimular o correto exercício dos direitos individuais e econômicos, bem como (iii) a correção das desigualdades sociais e o fomento à igualdade de oportunidades entre todos, a erradicação das discriminações e o asseguramento de um mínimo vital (educação, saúde, habitação, rendas, etc. $)^{203}$. Especificamente sobre a liberdade de empresa, ainda que fazendo referência ao direito espanhol, mas que vem bem a calhar com o presente, afirma Ariño ORTIZ o seguinte:

\footnotetext{
${ }^{202}$ Cf. MARQUES NETO, Floriano de Azevedo, O Fomento como Instrumento de Intervenção Estatal no Domínio Econômico, op. cit., páginas 59-62; CYRINO, André Rodrigues, Direito Constitucional Regulatório, op. cit., páginas 64-66; ARAGÃO, Alexandre Santos de, Agências Reguladoras, op. cit., páginas 132-133; OTERO, Paulo, Vinculação e Liberdade de Conformação Jurídica do Sector Empresarial do Estado, op. cit., páginas 38-45; FERRAZ JR., Tercio Sampaio, Congelamento de Preços - Tabelamentos Oficiais, in Revista de Direito Público - RDP, vol. 22, nº 91, São Paulo: Revista dos Tribunais, jul/set 1989, páginas 77-78; MOREIRA NETO, Diogo de Figueiredo, Curso de Direito Administrativo, op. cit., páginas 501-503. O mesmo Diogo de Figueiredo MOREIRA NETO deixa bastante claro o caráter não absoluto da livre iniciativa nos seguintes termos: "O princípio da liberdade de iniciativa tempera-se pelo da iniciativa suplementar do Estado; o princípio da liberdade de empresa corrige-se com o da definição da função social da empresa; o princípio da liberdade de lucro, bem como o da liberdade de competição, moderam-se com o da repressão do poder econômico; o princípio da liberdade de contratação limita-se pela aplicação dos princípios da valorização do trabalho e da harmonia e solidariedade entre as categorias sociais de produção; e, finalmente, o princípio da propriedade privada restringe-se como princípio da função social da propriedade." (Ordem Econômica e Desenvolvimento na Constituição de 1988, Rio de Janeiro: APEC, 1989, página 28)

${ }^{203}$ Principios de Derecho Público Económico, op. cit., páginas 109-110 e 113-114.
} 
"No entanto, como todas as liberdades, a liberdade de empresa tem limitações para a defesa de outros bens constitucionais e interesses sociais: o respeito aos direitos dos demais (art. $10.1 \mathrm{CE}$ ), entre eles 'a seguridade, a saúde e os legítimos interesses econômicos destes' (art. 51.1), as exigências da 'economia geral e, em seu caso, do planejamento' (art. 38 in fine), a subordinação de toda a riqueza do país ao interesse geral da nação (art. 128.1), os direitos dos trabalhadores e consumidores, e, acima de tudo, o respeito às leis do mercado e da concorrência leal. Assim, a liberdade de empresa deve ser regulada em seu exercício para que cumpra as condições impostas pela Constituição." 204

No mesmo sentido, Floriano de Azevedo MARQUES NETO é claro ao afirmar o seguinte:

"A regulação estatal é uma das formas de intervenção do Estado em face da ordem econômica. Desnecessário lembrar que a Constituição de 1988, ao par de prever o já referido papel do Estado como agente regulador da economia (artigo 174), previu o valor da livre iniciativa como fundamento da ordem econômica (artigo 170, caput) e fundamento da República (artigo $1^{\circ}$, IV, pareado com o valor social do trabalho). Temos daí um forte vetor de subsidiariedade na intervenção estatal, como já pude demonstrar em oportunidade anterior. No próprio texto constitucional, porém, encontramos os fatores que, por imposição da Carta, motivam e justificam a intervenção estatal. Trata-se do rol de objetivos constante do próprio artigo 170. Para concretizar tais princípios faz-se imperativo que o Estado intervenha na economia, preferencialmente manejando as competências a ele reservadas pelo artigo 174 (entre as quais o papel regulador se destaca)." 205

Assim, o que se tem é uma constatação absolutamente óbvia e que decorre diretamente da Constituição Federal: a legitimidade do Estado de intervir e regular a economia com o objetivo de perseguir valores constitucionalmente definidos, tais como a soberania nacional, a propriedade privada e sua função social, a redução das desigualdades regionais e sociais, a busca do pleno emprego, o desenvolvimento nacional, etc. Defender a existência de direitos absolutos, imponderáveis e irrestritos,

\footnotetext{
${ }^{204}$ Principios de Derecho Público Económico, op. cit., página 257 - tradução livre.

${ }^{205}$ Regulação Estatal e Autorregulação na Economia Contemporânea, op. cit., página 87.
} 
além de absurdo, é tema já em franco desuso até mesmo em matéria de direitos fundamentais, campo que mais recebeu análises dessa ordem.

E a controvérsia sobre a teoria interna e externa dos direitos fundamentais acaba sendo sintomática dessa afirmação. Com efeito, e de forma absolutamente resumida, tem-se que a teoria interna afirma que os direitos fundamentais não são passíveis de limitação externas (são, pois, de certo modo, absolutos), caracterizados pela existência apenas de limites imanentes, ou seja, limites internos aos próprios direitos $^{206}$. Por outro lado, a teoria externa parte do pressuposto que todos os direitos, e principalmente os fundamentais, são passiveis de limitação, do que há que se diferenciar os direitos prima facie dos direitos resultantes dos processos restrição contidos nas aplicações práticas ${ }^{207}$. Tais direitos podem ser restringidos por meios de outros direitos fundamentais ou por princípios, dando ensejo à utilização do mecanismo da ponderação ou do sopesamento, que tem como finalidade justamente definir seu conteúdo concreto. Portanto, e na esteira das lições de Virgílio Afonso da SILVA, é bastante evidente a "incompatibilidade entre a ideia de limites imanentes e a exigência de sopesamento", já que "se os limites de cada direito são definidos internamente e se não há possibilidade de restrição constitutiva externa, é evidente que não há qualquer possibilidade de sopesamento entre direitos fundamentais" ${ }^{208}$.

Toda essa digressão serve para dizer o óbvio: não existem direitos absolutos $^{209}$ e não é essa a concepção da livre iniciativa econômica que fundamenta o vetor de subsidiariedade da intervenção estatal. Nenhuma das teorias que cuidam dos limites aos direitos fundamentais admite direitos absolutos. A que mais se aproximaria de um direito irrestringível é a teoria interna (ao menos no que toca a restrições externas

${ }^{206}$ Para um relato dessa teoria cf. SILVA, Virgílio Afonso da, Direitos Fundamentais, op. cit., páginas 130-133; REIS, Jane, Interpretação Constitucional e Direitos Fundamentais, Rio de Janeiro: Renovar, 2006, páginas 141-146; BOROWSKI, Martin, La Estructura de los Derechos Fundamentales, Colômbia: Universidad Externado de Colombia, 2006, páginas 68-70.

${ }^{207}$ Cf. nesse sentido SILVA, Virgílio Afonso da, Direitos Fundamentais, op. cit., páginas 138-143; São Paulo: Malheiros Editores, 2009, páginas130-133; REIS, Jane, Interpretação Constitucional e Direitos Fundamentais, op. cit., páginas 146-152; BOROWSKI, Martin, La Estructura de los Derechos Fundamentales, op. cit., páginas 66-68.

${ }^{208}$ Direitos Fundamentais, op. cit., página 165.

${ }^{209}$ Como ensina Robert ALEXY, "[a] convicção de que existem direitos que não são relativizados nem mesmo sob circunstâncias as mais extremas - e apenas esses direitos são direitos genuinamente absolutos - pode ser defendida como vinculante pelo indivíduo que tenha a liberdade de se sacrificar em nome de determinadas máximas, mas não pode ser válida a partir da perspectiva do direito constitucional." (Teoria dos Direitos Fundamentais, São Paulo: Malheiros Editores, 2008, página 301) 
ao direito), que parece que vem perdendo adeptos ${ }^{210}$. Isso porque, se a teoria interna é antípoda da ideia de ponderação ou sopesamento de princípios e direitos, a cada vez mais ampla utilização desses elementos na argumentação jurídica tanto da doutrina quanto da jurisprudência ${ }^{211}$ indica claramente um atual desuso falar atualmente em direitos irrestringíveis, até mesmo em matéria de direitos fundamentais.

Portanto, não havendo muito sentido defender ou mesmo imaginar a livre iniciativa como um direito absoluto ou irrestringível, quer nos parecer que as críticas feitas pelos autores que negam a subsidiariedade como um vetor de restrição à intervenção estatal na economia são feitas com base em uma imagem irreal e que não representa nem de longe o conceito utilizado. Bem é verdade que há autores que defendem a impossibilidade de qualquer cerceamento regulatório da livre iniciativa ${ }^{212}$, mas além de isolados, fazem uma análise superficial do tema. De todo modo, por mal dirigidas, grande parte das críticas feitas ao vetor da subsidiariedade na intervenção estatal acabam se mostrando estéreis, já que trabalham com uma imagem que não corresponde à realidade.

\section{III.4.1.c. Compreensão fundamentalista ou neutra da ordem econômica? A confusão entre o conceito de subsidiariedade e sua utilização prática}

Outra parte das críticas, bastante substancial aliás, cuida de afirmar que a tese da subsidiariedade na intervenção estatal na economia configura captura ideológica da Constituição, uma teoria fundamentalista da livre iniciativa, verdadeira tentativa de impor determinada ideologia às maiorias, ou, como quer Cláudio Pereira

\footnotetext{
${ }^{210}$ Conforme anota Jane REIS, a posição que defende a teoria interna é minoritária, muito embora tenham aumentado de número recentemente (Interpretação Constitucional e Direitos Fundamentais, op. cit., páginas 148-189). A autora colaciona as ideias de Friedrich Müller (na Alemanha), Ignacio de Otto y Pardo (Espanha), Antonio-Luis Martinez-Pujalte (Espanha), Juan Cianciardo (Espanha), Tomás de Domingo Pérez (Espanha), Pedro Serna e Fernando Toller (Argentina).

${ }^{211}$ Ampla utilização essa que leva Ricardo Lobo TORRES a se referir a um verdadeiro princípio da ponderação e, citando Walter Leisner e Thomas Würtemberger, até mesmo um Estado de ponderação (cf. A Legitimação dos Direitos Humanos e os Princípios da Ponderação e da Razoabilidade, in TORRES, Ricardo Lobo, Legitimação dos Direitos Humanos, $2^{a}$ ed., Rio de Janeiro: Renovar, 2007, páginas 491496)

${ }^{212}$ Cf. PEDREIRA, Carlos Eduardo Bulhões, Monopólio - Gás, in Revista Trimestral de Direito Público - RTDP, n 10, São Paulo: Malheiros Editores, 1995, página 144.
} 
de SOUZA NETO, uma expressão do neocolonialismo econômico ${ }^{213}$. Nesse sentido, aduz José Vicente Santos de MENDONÇA que a subsidiariedade, conforme defendida pela doutrina, não configura uma teoria neutra, mas sim é representativa da ideologia econômico-liberal $^{214}$, ou até mesmo do neoliberalismo, como prefere Emerson GABARDO $^{215}$. Não sendo neutra, a subsidiariedade não poderia ser fundada em preceito constitucional, já que representaria uma doutrina abrangente e particular, sob pena de cercear o espaço democrático e tornar constitucionalmente necessário o que é politicamente contingente ${ }^{216}$.

Embora juridicamente consistentes, todas estas afirmações não nos convencem, eis que baseadas em um equívoco fundamental: a percepção de que a subsidiariedade predicaria um tamanho mínimo ou menor de Estado, ou que tomaria por pressuposto uma ideologia específica que privilegiaria a livre iniciativa em detrimento de outros princípios, direitos e valores constitucionais. Em verdade, trata-se de erro bastante vinculado à visão caricata da subsidiariedade acima indicada. Representa, pois, a notória confusão entre o conceito da subsidiariedade com as teorias que dele se utilizaram para defender determinado ponto de vista a respeito do protagonismo estatal, notadamente em seara econômica. E é bastante fácil perceber isso.

Em primeiro lugar, note-se que a subsidiariedade não defende um Estado maior ou menor, sequer se atenta para o tamanho do aparelho estatal. Em segundo lugar, a subsidiariedade não prega qualquer forma de não intervencionismo ou absenteísmo do Poder Público, ao contrário, toma como pressuposto justamente a necessidade de intervenção estatal sempre que verificados interesses públicos legítimos que suplantem a auto-capacidade dos corpos sociais de garanti-los. A subsidiariedade, portanto, parte do pressuposto inverso, o de que a intervenção estatal é sim necessária, mas deve ser responsável e lastreada em dados reais, verificados a partir da constatação de necessidades públicas legítimas e de custo-benefício social (conforme abordaremos com mais vagar adiante). Aqui, portanto, a subsidiariedade adquire um caráter de

${ }^{213}$ Cf. O Dilema Constitucional Contemporâneo entre o Neoconstitucionalismo Econômico e o Constitucionalismo Democrático, in SOUZA NETO, Cláudio Pereira, Constitucionalismo Democrático e Governo das Razões, Rio de Janeiro: 2011, Lumen Juris, página 35.

${ }^{214}$ Direito Constitucional Econômico, op. cit., página 260.

${ }^{215}$ Interesse Público e Subsidiariedade, op. cit., página 221.

${ }^{216}$ Cf. PEREIRA NETO, Cláudio Souza e MENDONÇA, José Vicente Santos de, Fundamentalização e Fundamentalismo na Interpretação do Princípio Constitucional da Livre Iniciativa, op. cit., página 721. 
responsividade ${ }^{217}$, de garantia de que a intervenção estatal é necessária e se mostra a melhor opção possível para atingir determinados fins de interesse coletivo.

A confusão perpetrada pelos seus críticos parece ter clara origem na indevida associação da subsidiariedade ao próprio discurso de determinados autores que pregam um absenteísmo estatal, ou então no que se costumou chamar de "postulados liberais, religiosos ou 'liberais-religiosos"'1218. De fato, é bastante razoável e até mesmo intuitivo que a defesa de um Estado minimizado seja fundamentada na subsidiariedade, entendida no sentido de diminuir o aparato estatal, restringir as incidências interventivas e dar mais espaços aos corpos sociais para definir os desígnios da sociedade. A subsidiariedade poderia ser também facilmente utilizada para fundamentar um típico modelo liberal de mercado, que inadmitisse quaisquer intervenções que afetassem o mercado, bastaria acreditar nas teorias do laissez-faire smithianas. Entretanto, em vista do duplo caráter da subsidiariedade, que ao mesmo tempo que limita intervenções ociosas (pois que indiferentes à autossuficiência privada) obriga também o Estado a agir na garantia de bens e valores de interesse público (ante a comprovada incapacidade privada), é possível sua utilização também para fundamentar teorias intervencionistas ou mesmo autoritárias.

Prova contumaz disso é a ampla gama de modelos estatais que se utilizaram da subsidiariedade para basear determinado protagonismo estatal. A igreja católica o fez para proteger o proletariado fragilizado ante as consequências da primeira

\footnotetext{
${ }^{217}$ Segundo anota Diogo de Figueiredo MOREIRA NETO, "[o] princípio da responsividade vem, por isso, complementar o princípio da responsabilidade e ampliar-lhe os efeitos, além da legalidade estrita, para inspirar e fundar ações preventivas, corretivas e sancionatórias do Direito Administrativo voltadas à preservação do princípio democrático e da legitimidade, como qualidade que dele decorre. $\mathrm{Na}$ verdade, tomada em seu sentido mais dilatado, a responsividade, tal como surgiu nos estudos empreendidos sobre a participação política, é princípio instrumental da democracia, uma vez que se destina a salvaguardar a legitimidade, ou seja, a conciliar a expressão da vontade popular, democraticamente recolhida, com a racionalidade pública. (...) Neste sentido, a responsividade está para a realização do Estado Democrático assim como a clássica responsabilidade está para a realização do Estado de Direito." (Curso de Direito Administrativo, op. cit., página 92) Em outra obra, o mesmo autor explica a evolução do conceito: "No Estado de Direito impera o princípio da responsabilidade, que vem a ser, no caso, o tradicional dever de observância da legalidade pelo administrador público, respondendo política, administrativa, penal e civilmente pelos seus atos. No Estado Democrático de Direito se inova o princípio da responsividade, introduzindo um novo dever substantivo, em razão do qual o administrador público também fica obrigado a prestar contas à sociedade pela legitimidade de seus atos. A responsividade consiste, portanto, em apertada síntese, na obrigação de o administrador público responder pela violação da legitimidade, ou seja, pela postergação ou deformação administrativa da vontade geral, que foi regulamente expressa, explícita ou implicitamente, na ordem jurídica." (Considerações sobre a Lei de Responsabilidade Fiscal, Rio de Janeiro: Renovar, 2001, página 60)

${ }^{218}$ Cf. GABARDO, Emerson, Interesse Público e Subsidiariedade, op. cit., página 223.
} 
revolução industrial, pregando, para além da especificação dos direitos e deveres de ricos, pobres, proprietários e trabalhadores, também uma responsabilidade socioeconômica estatal em alguma medida novidadeira para a época ${ }^{219}$. Mussolini e Franco utilizaram-se da mesma subsidiariedade para estruturar a iniciativa econômica pública em regimes autoritários, fazendo surgir no Brasil um clientelismo que distorceu completamente a ideia do capitalismo brasileiro (aquele sem risco), na arguta observação de Gilberto BERCOVICI ${ }^{220}$.

Assim, defender a existência de um vetor de subsidiariedade como elemento de restrição à intervenção estatal no domínio econômico não significa dizer que o Estado deve ser mínimo ou máximo, grande ou pequeno, atuante ou passivo, protagonista ou regulador. Significa apenas dizer que a intervenção estatal somente tem lugar quando verificada a incapacidade dos atores sociais privados em garantir as pautas de interesse da coletividade vislumbradas pelo Poder Público. Pode haver mais ou menos intervenção, fundamentada em todos os chamados princípios da ordem econômica contidos no artigo 170 da Constituição Federal, o que garante a implementação de toda sorte de políticas públicas econômicas. Entretanto, há que se respeitar a eventual autossuficiência dos agentes privados em garanti-las, o que acaba legitimando a ação estatal. Esta a essência de uma intervenção do Estado no domínio econômico adequadamente subsidiária.

Parece-nos, portanto, equivocado tachar a subsidiariedade de mecanismo ideologicamente viciado, de vetor relacionado unicamente às teorias liberais. São os teóricos liberais que mais dela se utilizaram para fundamentar seus posicionamentos, assim como, ainda que em menor grau, também já se fez para basear doutrinas intervencionistas e fascistas. É equivocado dizer que a subsidiariedade reduz o espectro de possíveis escolhas democráticas. Como acertadamente aponta José Vicente Santos de MENDONÇA, a "[a] questão a respeito de maior ou menor intervenção do Estado na economia não é, de ordinário, uma questão constitucional" ${ }^{221}$. E a subsidiariedade logicamente não a constitucionaliza, apenas exige o cumprimento de um requisito inerente ao ordenamento brasileiro (o respeito à eventual autossuficiência

\footnotetext{
${ }^{219}$ Cf. LAPOINTE, Benoît, Le principe de subsidiarité sous l'éclairage de l'enseignement social de l'Eglise, op. cit., página 449.

${ }^{220}$ Direito Econômico do Petróleo e dos Recursos Minerais, op. cit., p. 270.

${ }^{221}$ Direito Constitucional Econômico, op. cit., página 263.
} 
dos protagonistas privados), garantindo que a decisão acerca de mais ou menos intervenção, desde que legítima, seja pauta de políticas públicas econômicas.

Logo, parece fundamental reconhecer que a subsidiariedade tal como vislumbrada aqui (e que, se bem entendida, configura posição amplamente majoritária entre os autores que nela se debruçam) se trata, sim, de uma teoria ideologicamente neutra, que aceita fundamentos ideológicos de toda ordem, mas que funciona como uma regra objetiva, vinculada ao dever de intervenção estatal fundamentada e responsável. Cuida, pois, de mecanismo idôneo, apto a figurar no debate acerca do protagonismo estatal em seara econômica.

\section{III.4.1.d. Desconfiança dos atores econômicos privados}

Outro problema verificado em parte dos argumentos utilizados pelos críticos da subsidiariedade reside em uma visão bastante desconfiada dos agentes privados e da própria sociedade. Nesse sentido, não raro são tratados como se fossem impreterivelmente movidos por interesses egoísticos e espúrios, sempre prontos a obter ganhos ilegítimos em face da coletividade e do Poder Público. Esse posicionamento fica claro com a tentativa de se costurar uma intervenção estatal econômica autônoma, autorreferencial e auto-justificada, cuja existência se reconhece como um fim em si mesmo, independentemente até mesmo da existência de uma finalidade pública prédefinida. No mais, argumentações que vinculam obrigatoriamente o livre intervencionismo estatal com as conhecidas pautas socioeconômicas que fundamentam a ordem econômica (disciplinadas no conhecido artigo 170 da CF) somente demonstram que se parte do pressuposto de negar, como regra geral, a capacidade dos agentes privados de implementar pautas de interesse público.

Entretanto, essa visão, além de (i) partir de um vício de origem evidente, mostra-se absolutamente desapegada ao atual estágio de reflexão sobre as bases da cidadania e da sociedade civil, possuindo, assim, duas consequências bastante indesejáveis: (ii) de um lado, enseja a falsa sensação de ser o Estado o único legitimado a tutelar interesses públicos legítimos; (iii) de outro, traduz um irreal antagonismo entre interesses privados e interesses públicos, como se a convergência só fosse possível pela 
coerção $^{222}$. Há aqui, portanto, muito da ideia de supremacia do interesse público (coletivo heterogêneo) sobre o privado (em regra, privatístico e ilegítimo).

Comecemos pelo vício. Com efeito, note-se que esse sentimento de desconfiança dos particulares, em alguma medida comum entre nós, tem origem em uma distorção elementar da forma como os Estados latino-americanos foram instituídos ${ }^{223}$. O natural, ao menos como diz tradição europeia por nós herdada, é que o Estado fosse criado e fundamentado na necessidade de garantir os direitos dos indivíduos e ordenar a vida em sociedade ${ }^{224}$. No Brasil e nos demais países da América Latina, entretanto, o processo foi o inverso: durante o período colonial, todo o aparato estatal (judiciário, fiscal, policial, notarial) foi transposto para as colônias não para garantir direitos dos indivíduos organizados em sociedade, mas sim para marcar a presença do Estado-Colônia ${ }^{225}$.

Esse processo distorcido inverteu também a noção e os papéis desempenhados pelas esferas pública e privada. Ao invés de ser visto como uma organização que tem sua legitimidade vincada na garantia dos direitos dos cidadãos, o Estado dos países latino-americanos tende à auto-referência, possuindo interesses próprios e superiores às necessidades sociais. Os particulares, ao contrário de terem sua

\footnotetext{
${ }^{222}$ A esse respeito, interessante notar que embora José Vicente Santos de MENDONÇA concorde com inexistência obrigatória de oposição entre interesse público e interesse privado (Direito Constitucional Econômico, op. cit., página 202), alega ser contraditório defender a inexistência de supremacia do interesse público e a subsidiariedade ao mesmo tempo. Segundo ele, "por idênticas razões, (i) não pode logicamente haver um 'princípio da supremacia', (ii) melhor seria a defesa de um 'melhor interesse econômico', que, no mais das vezes, é concretizado pelo desempenho econômico privado, mas que também pode legitimamente ser realizado pela atividade empresarial pública, sem que isso seja, obrigatoriamente, uma 'exceção excepcionalíssima', uma ultima ratio." (op. cit., página 265) Novamente a falha do raciocínio reside na vinculação da subsidiariedade a uma caricatura, uma espécie de regra de absoluta exceção. Conforme veremos adiante, a intervenção estatal não deve ser excepcionalíssima, deve ser fundamentada em interesse público, o qual inexiste se os atores privados comprovadamente puderem implementar as demandas sociais por conta própria.

${ }^{223}$ Cf. MARQUES NETO, Floriano de Azevedo, Interesses Públicos e Privados na Atividade Estatal de Regulação, in MARRARA, Thiago (org.), Princípios de Direito Administrativo, São Paulo: Atlas, 2012, páginas 421-423.

${ }^{224}$ Cf. MIRANDA, Jorge, Teoria do Estado e da Constituição, Coimbra: Coimbra Editora, 2002, páginas 336-337; HAURIOU, Maurice, Principios de Derecho Público y Constitucional, Madrid: Instituto Editorial Reus, 1927, páginas 39-45; ZIPPELIUS, Reinhold, Teoria Geral do Estado, op. cit., páginas 157-161; MARQUES NETO, Floriano de Azevedo, Regulação Estatal e Interesses Públicos, op. cit., páginas 50-55.

${ }^{225}$ No caso brasileiro, para uma descrição detalhada desse processo de colonização baseado unicamente nos interesses da Coroa Portuguesa, ver FAORO, Raymundo, Os Donos do Poder, $4^{\mathrm{a}}$ ed., São Paulo: Globo, 2008, páginas 128-145. Já sob uma perspectiva constitucional ver SILVA, José Afonso, Curso de Direito Constitucional, op. cit., páginas 69-77.
} 
liberdade resguardada e em alguma medida exaltada ${ }^{226}$, acabam sendo vistos com desconfiança, como se fossem agentes egoístas por natureza, sempre prontos a se beneficiar da riqueza coletiva tutelada pelo Estado. Daí o sentido da observação de Floriano de Azevedo MARQUES NETO, que embora longa merece aqui integralmente ser transcrita:

\begin{abstract}
"Numa esfera pública serviente à sociedade, a intervenção na esfera privada é aceitável em condições excepcionais. Apenas quando a atividade interventiva for justificada para impedir a violação ou imprescindivel para a consagração de direitos fundamentais é que se admite que o Estado interfira na economia, na sociedade, na cultura, nos costumes. (...) Nas sociedades em que se valoriza a esfera privada, portanto, a intervenção estatal é marcada por um traço de subsidiariedade: só aceitável quando a sociedade e os atores privados, por si, não forem capazes de assegurar o direito fundamental a ser protegido ou promovido. (...)
\end{abstract}

Em outras sociedades, que corresponderam desafortunadamente à maioria das nações latino-americanas ao longo dos últimos séculos, a dinâmica público-privado é invertida. A esfera pública é tomada exclusivamente como a esfera do Estado. (...) Mais do que haver uma maior dependência do Estado ou uma maior leniência à intervenção estatal na esfera privada, predominou na América Latina, por tempos, a concepção de que a esfera pública é o repositório das virtudes e a esfera privada o campo dos vícios, o plano em que prevalece a cupidez e o egoísmo dos atores privados. Para as sociedades com essa formação ideológica, a intrusão estatal na vida privada seria sempre bem-vinda e bem aceira, pois ela seria prenhe da boanova do interesse público. (...)

Daí a desconfiança com a iniciativa privada e a preferência, recôndita e subliminar, pelo provimento de utilidades públicas por entes estatais. O que me levou, num pequeno texto publicado há alguns anos, a afirmar que entre

\footnotetext{
${ }^{226}$ Exemplo de uma concepção respeitadora da liberdade privada e que compreende a intervenção estatal como exceção pode ser extraída das ideias de Eduardo Garcia de ENTERRÍA e de Tomás-Ramón FERNÁNDEZ, para quem "[p]arece indiscutível que em caso de dúvida quanto à respeito da técnica de intervenção concretamente utilizável haverá que optar pela que suponha uma menor restrição da liberdade. In dubio pro libertate é um princípio inescusável na matéria, que, embora já tivesse consagração positiva no ordenamento pré-constitucional (...), agora se apresenta com força renovada que se presta o dispositivo constitucional. A liberdade é a regra; a limitação é, no entanto, a exceção, como tal, deve ser interpretada restritivamente" (Curso de Derecho Administrativo, vol. II, $11^{\mathrm{a}}$ ed., Madrid: Civitas, 2008, página 116 - tradução livre). Mesmo sentido aponta Juan Alfonso SANTAMARÍA PASTOR, para quem, em termos de intervenção estatal na liberdade privada, além de um critério de proporcionalidade (que veta a atribuição de poderes materialmente desnecessários para alcançar os fins desejados pela Administração), rege-se também pelo "princípio pro libertate ou favor libertate, segundo o qual a regra que estabelece o poder de intervenção pode razoavelmente escolher entre várias medidas alternativas para atingir o seu objetivo ordenador, deve necessariamente eleger a que resulte menos restritiva da liberdade individual dos sujeitos sobre os que vá ser empregada" (Principios de Derecho Administrativo General, vol. II, Madrid: Iustel, 2009, página 263 - tradução livre).
} 
nós não se acredita ou louva o mercado: o aceitamos a contragosto, quase como um mal necessário." 227

Portanto, parece-nos que tratar os atores privados e o próprio mercado com desconfiança, como se fossem voltados única e exclusivamente à cupidez e à satisfação de seus interesses egoísticos e espúrios, nada tem a ver com a proteção de desfavorecidos ou a erradicação da desigualdade social. Trata-se, em verdade, da propagação de um equívoco, de uma reprodução de vícios que têm origem na própria formação do Estado brasileiro, e que acabou maculando o imaginário social da maioria da população. Como resultado, acaba-se por estimular uma concepção autoritária da atividade do Estado, o qual, nesse contexto, prescinde de muitas justificativas para intervir no domínio econômico e o faz muitas vezes dotado de interesses próprios, desvinculados da satisfação das necessidades coletivas.

Mas nem mesmo sob uma perspectiva sociológica a vinculação entre interesse privado e egoísmo se fundamenta em algo real, mas sim em uma outra distorção. É que essa visão quase hobbesiana dos agentes privados movidos apenas pela cupidez denota a contaminação do que Charles TAYLOR chama de imaginário social "Grotian-Lockean", vincado, pois, nos conceitos Hugo Grócio e John Locke sobre o que é e como funciona a sociedade ${ }^{228}$. Daí o sentido da observação de Víctor PÉREZDÍAZ, para quem "as vozes de hoje dos mercados e das políticas democrática sugerem, de forma considerável, uma versão individualista de um imaginário social moderno no qual indivíduos sensíveis e sociáveis se empenham em interações para seu benefício mútuo e na busca de seus próprios interesses, sob a forma de trocas econômicas ou de uma troca política entre os cidadãos e os diversos segmentos da classe política" ${ }^{229}$.

\footnotetext{
${ }^{227}$ Interesses Públicos e Privados na Atividade Estatal de Regulação, op. cit., páginas 422-423 e 428.

${ }^{228}$ A associação a Hugo Grócio remete ao conceito de seres humanos como agentes racionais e sociais dedicados a colaborar em paz para o seu mútuo benefício. Por outro lado, Locke foi o primeiro teórico a utilizar essa teoria como fundamento para a revolução e como base para um governo limitado. Segundo TAYLOR, "[n]os próximos três séculos, de Locke aos dias atuais, embora a linguagem contratual tenha perdido adeptos e seja usada apenas por uma minoria de teóricos, a ideia subjacente de sociedade como existente para o (mútuo) benefício dos indivíduos e em defensa de seus direitos assume cada vez mais importância. Isto é, ambas chegam à visão dominante, colocando teorias mais antigas da sociedade e novas ideias rivais à margem da vida e do discurso político, e isso também gera mais e mais abrangentes questionamentos sobre a vida politica" (Modern Social Imaginaries, Londres: Duke University Press, 2004, p. 3-5 - tradução livre)

229 The Voices of Civil Societies, ASP Reserarch Paper 83(b)/2008, página 3. Disponível em: http://www.asp-research.com/pdf/Asp\%2083b.pdf.
} 
Quer dizer, somente uma visão enviesada da sociedade e que se traduz em um imaginário social distorcido é que toma como pressuposto os atores privados como agentes naturalmente egoístas, cujo único móvel seria o benefício próprio. Mas não é só. Em segundo lugar, esse problema de concepção traz resultados bastante indesejáveis ao relacionamento público/privado. Referimo-nos aqui à falsa sensação de ser o Estado o único legitimado a tutelar interesses públicos.

Nesse sentido, é sabido que a fragmentação social, que é pressuposto do chamado Estado pós-moderno ou pluralista (ou qualquer nome que se queira dar), provocou uma reordenação dos papéis do Estado e da sociedade, dando ensejo ao que Pedro António P. Costa GONÇALVES chama de "deliberado 'aproveitamento', 'mobilização' e 'activação' da capacidade dos particulares para a realização de objectivos e fins públicos" ${ }^{230}$. É que, de forma bastante resumida, tem-se que esse fracionamento social inevitável (eis que decorrente da própria evolução da sociedade) acabou por ensejar a emergência de grupos sociais distintos, segmentados e detentores de interesses internamente legitimados e muitas vezes externamente contraditórios ${ }^{231}$. Pois ao invés de negá-los, o mesmo Estado se viu obrigado a reconhecê-los e tutelá-los, o que colocou em xeque a velha noção de interesse público universal, absoluto, singular e titularizado unicamente pelo Poder Público

Justamente sob esse contexto é que se afirma que, "[a]o menos nos dias de hoje, interesses legítimos, mediatos ou imediatos, de um particular não podem significar automaticamente um interesse contrário aos desígnios públicos", de modo que muitas vezes "o atendimento aos interesses dos particulares nada mais é que a consagração de interesses públicos" ${ }^{232}$. Decorre daí, portanto, o equívoco histórico e conceitual de se pretender corporizar apenas no Estado a tutela dos interesses públicos. O papel que tem sido outorgado à sociedade e os particulares transcende e muito a de meros expectadores das ilustres intervenções estatais. Utilidades absolutamente essenciais à coletividade (dotados, pois, de inegável interesse público) são diariamente

\footnotetext{
${ }^{230}$ Estado de Garantia e Mercado, in SADDY, A. E MARTÍNEZ, Aurilivi Linares (coords.), Direito das Infraestruturas: um estudo dos distintos mercados regulados, Rio de Janeiro: Lumen Juris, 2011, página 25.

${ }^{231}$ Esse processo de fragmentação social é detalhadamente descrito por MARQUES NETO, Floriano de Azevedo, Regulação Estatal e Interesses Públicos, São Paulo: Malheiros Editores, 2002, páginas 115124.

${ }^{232}$ MARQUeS NETO, Floriano de Azevedo, Regulação Estatal e Interesses Públicos, op. cit., página 152.
} 
providas por particulares, como a comercialização de alimentos, educação, saúde, assistência social, transporte, comunicação, etc., o que acaba por expor o equívoco.

Por fim, em terceiro lugar, todo esse problema resulta na concepção equivocada de que existiria uma contraposição ex ante entre interesse público (monopolizado pelo Poder Público) e interesses privados (eivados de interesses particularísticos).

Ora, se há interesses públicos legítimos titularizados pelos atores privados, não faz muito sentido presumir que simplesmente por serem privados se tratariam de interesses antagônicos aos detidos pela coletividade. Em outras palavras, admitindo-se a existência de interesses públicos legítimos titularizados tanto pelos particulares como pela coletividade, a distinção e contraposição baseada na figura de seu detentor perde completamente o sentido ${ }^{233}$. Nesse sentido, há mais de 30 anos, dizia-nos Miguel Sanchez MORÓN o seguinte:

"A divisão magna e categorial entre os interesses privados, individuais e formalmente iguais, e o interesse geral, ontologicamente distinto daqueles, é uma ficção jurídica, um mito do século XIX, que já se tornou história, pois a cada dia se manifesta mais incapaz de assumir as funções que lhe foram encomendadas, a saber, servir de fundamento a todo um conjunto de soluções jurídicas práticas, juridificar as relações entre o soberano e os súditos, e ao mesmo tempo aglutinar o consenso ideológico em torno do caráter essencialmente neutro da estrutura administrativa." 234

Nesse sentido, há um exemplo prático que vivenciamos diariamente e que bem demonstra o quanto aqui foi exposto. Refere-se à forma como o setor de

\footnotetext{
${ }^{233}$ Daí o acerto da conclusão de Floriano de Azevedo MARQUES NETO, segundo a qual "[n]ão mais podendo ser sustentada a existência de um interesse público (prescrito em lei ou identificado pela burocracia), não há como aceitar a tese de oposição e supremacia absoluta deste interesses geral frente aos diversos interesses encontradiços na sociedade - interesses, estes, que, inclusive, acabam por estar refletidos, a partir de locuções genéricas ou de cláusulas abertas (...), na lei ou mesmo na Constituição. (...) Em outras palavras: as transformações havidas na sociedade e no Estado contemporâneos põem em xeque a concepção clássica de prevalência absoluta e indesviável do Estado sobre a sociedade; da Administração sobre o administrado; do público sobre o privado." (Regulação Estatal e Interesses Públicos, op. cit., página 156)

${ }^{234}$ El principio de participación en la Constitución española, in Revista de Administración Pública, $\mathrm{n}^{\circ}$ 89, Madrid: Centro de Estudios Políticos y Constitucionales, mai/ago 1979, página 172 - tradução livre. No mesmo sentido, como anota Massimo Severo GIANNINI a respeito da contraposição entre interesses públicos e privados, "[c]om a chegada do Estado pluriclasse esta teorização se revelou inadequada, porque ocorria que o interesse de grupos heterogêneos foram uns e outros qualificados como públicos e tutelados por leis estatais" (Diritto Amministrativo, op. cit., página 110 - tradução livre).
} 
telecomunicações no Brasil tem evoluído ao longo dos anos e qual o papel do Poder Público na sua universalização.

Como é sabido, desde o início dos anos setenta até meados de 1997 os serviços de telecomunicações no Brasil eram prestados em regime de monopólio estatal a cargo da TELEBRÁs ${ }^{235}$. Após a edição da Emenda Constitucional $n^{\circ} 8$ e da Lei $n^{\circ}$ 9.295/96, foi editada a Lei Geral de Telecomunicações - LGT (Lei n 9.472/97), que criou a Agência Nacional de Telecomunicações - ANATEL e quebrou definitivamente o monopólio estatal ${ }^{236}$, abrindo os serviços à exploração privada. Foram, como se sabe, instituídos dois regimes de prestação dos serviços: um de caráter público, a ser delegado em regime de concessão (arts. 79 e seguintes da LGT), do qual é exemplo o serviço de telefonia fixa (parágrafo único do artigo 64); e outro em regime privado, sujeito a meras autorizações de exploração (conceituadas pela Lei como atos administrativos vinculados ${ }^{237}$ ).

O Serviço Móvel Celular - SMC, conquanto tenha sido outorgado à iniciativa privada por meio do instrumento das concessões, sempre foi prestado em regime privado. Como anota com precisão Jacintho Arruda CÂMARA, no que toca ao SMC (hoje substituído pelo Serviço Móvel Pessoal - SMP), "[é] certo que o Estado fiscaliza sua prestação, determina as principais regras a serem observadas $e$ administra recursos imprescindíveis à sua existência (espectro radioelétrico, p. ex.); mas nenhuma dessas intervenções tem como finalidade precípua a garantia de sua universalização, nem implica a assunção do compromisso de manter tal serviço. (...) $O$

\footnotetext{
${ }^{235}$ Cf. BRASIL, Ministério das Comunicações, Exposição de Motivos no 231, dez/1996, páginas 04-05

${ }^{236}$ Note-se, entretanto, que Floriano de Azevedo MARQUES NETO aponta para o fato de que "[f]oi justamente esta evolução tecnológica que quebrou o monopólio do serviço de telecomunicações muito antes da Emenda Constitucional 8, de 1995. Quando a TELEBRÁS monopolizava este setor os grandes usuários de telecomunicações, por exemplo, na ligação de longa distância internacional, já simplesmente furavam o monopólio fazendo callback, demonstração cabal de que a tecnologia, na verdade, quebrou o monopólio legal muito antes de o constituinte ter feito esta alteração." (Direito das Telecomunicações e ANATEL, in SUNDFELD, Carlos Ari (coord.), Direito Administrativo Econômico, São Paulo: Malheiros Editores, 2006, páginas 309-310)

${ }^{237}$ Acerca da discussão entre o conceito clássico de autorização manuseado pela doutrina por anos e a definição positivada na LGT, ver o interessante estudo de CÂMARA, Jacintho Arruda, As autorizações da Lei Geral de Telecomunicações e a Teoria Geral do Direito Administrativo, in Revista de Direito de Informática e Telecomunicações - RDIT, nº 3, Belo Horizonte: Fórum, jul/dez 2003, páginas 55-68.
} 
Serviço Móvel Celular, em suma, não é - e nunca foi - tratado como um serviço essencial, como um serviço público propriamente" ${ }^{, 238}$.

Por outro lado, o serviço de telefonia fixo foi tratado pela LGT como um serviço público, vincado, portanto, em precisas e rígidas pautas de universalização de sua prestação. Basta uma mera análise dos contratos de concessão elaborados (e que foram posteriormente celebrados) para se constatar a enorme preocupação do Poder Concedente em regular a constante melhoria da prestação dos serviços (algo fundamental em um mercado tão marcado pela tecnologia) e sua ampliação a um cada vez maior número de usuários potenciais ${ }^{239}$.

Hoje, pode-se dizer que a principal utilidade pública subjacente aos serviços de telecomunicações (comunicação das pessoas) é acessível à grande maioria da população brasileira ${ }^{240}$. O grande responsável por tal conquista, entretanto, não foi o serviço público fortemente regulado (telefonia fixa), mas sim o serviço móvel prestado em regime privado de competição de mercado $^{241}$, cujas soluções concorrenciais deram

${ }^{238}$ Cf. A Nova Regulamentação do Serviço de Telefonia Celular - Serviço Móvel Pessoal: O Sucedâneo do Serviço Móvel Celular, in Fórum Administrativo, n 5, Belo Horizonte: jul/2001, página 589

${ }^{239}$ Cf., nesse sentido, o modelo de Contrato de Concessão para a Prestação do Serviço Telefônico Fixo Comutado nas modalidades Local, Longa Distância Nacional e Longa Distância Internacional, objeto da Resolução no 26/98 da ANATEL. A titulo de exemplo, veja-se que os concessionários têm de cumprir e custear as metas do Plano Geral de Metas de Universalização (Cláusulas 7.1 e 7.2), mesmo as que não tiverem sido previstas no contrato (Cláusula 7.3), da mesma forma como têm de implementar projetos de expansão e universalização do serviço demandados pela ANATEL (Cláusula 15.1, XIX), observar os indicadores de qualidade dos serviços, inclusive os decorrentes do grau de satisfação dos usuários conforme avaliados pela ANATEL (Cláusula 6.5), assim como constantemente introduzir equipamentos, processos e mecanismos de atualização tecnológica dos serviços.

${ }^{240}$ Segundo os últimos dados do PNAD divulgados pelo IBGE, até 2009, 84,35\% dos domicílios brasileiros possuíam algum tipo de telefone. (disponível em: http://www.ibge.gov.br/home/presidencia Inoticias/noticia_visualiza.php?id_noticia $=1708$ )

${ }^{241}$ A análise dos dados disponibilizados pelo IBGE comprova a assertiva. Em 2001, 58,9\% da população brasileira já possuía algum telefone em suas residências, sendo que destes 7,8\% possuíam apenas celular e $51,1 \%$ apenas fixo. Em 2002, 61,1\% da população já possuía acesso à telefonia, sendo, destes, $8,8 \%$ celular e $52,8 \%$ fixo. Em 2003, foram contabilizados $62 \%$ de residências com algum tipo de telefonia, dos quais $11,2 \%$ referiam-se a celulares apenas e 50,8\% a telefones fixos. Em 2004, subiu para $65,4 \%$ o número de residências com acesso a telefones, sendo que destes 16,5\% possuíam apenas celular e 48,9\% possuíam apenas telefone fixo. Em $2005,71,6 \%$ da população possuía algum tipo de telefone em casa, sendo $23,5 \%$ só possuía celular e $48,8 \%$ somente fixo. Em 2006, subiu para 74,5\% o número de residências com telefone, nos quais $27,7 \%$ somente possuíam celular e 46,8\% telefone fixo. Em 2007 foi verificado em $77,7 \%$ das residências brasileiras possuía algum tipo de telefonia, dos quais 31,6\% apenas com celular e 45,4\% apenas com fixo. Em 2008 o percentual de residências com algum tipo de telefone aumentou para $82,1 \%$, sendo que destes $37,6 \%$ referiam-se apenas a celular e $44,4 \%$ apenas fixo. Em 2009 , o numero total de residências com telefone foi para $84,3 \%$, dos quais $41,2 \%$ possuíam apenas celular e $43,1 \%$ apenas fixo. Até junho de 2011, os dados eram que a telefonia celular importava em uma densidade de 123,90 cel/100 hab, ou seja, já havia mais celulares habilitados e funcionando no Brasil do que habitantes. A conclusão disso é que, de 2001 (primeiro ano que o IBGE analisou a relação telefonia 
vida a utilidades de baixíssimo custo e acessíveis à população de baixa renda (celular pré-pago) ${ }^{242}$. Portanto, contrariando todas as previsões e premissas do próprio ente regulador do setor, foram as soluções encontradas pelos particulares sem muitas diretrizes públicas que trouxeram os maiores avanços tutelados pelo Estado em matéria de telecomunicações.

Com isso fica claro que propagar a ideia de que os agentes econômicos são naturalmente incapazes de atingir fins de interesse público, como regra, equivocado. É também Victor PÉREZ-DÍAZ quem anota que os agentes privados atuando no mercado acabam gerando consequências que se distanciam bastante da visão individualista generalizada que estamos tentando desconstruir. Trata-se do que chama de mercado como instrumento dialógico, ou seja, "como um sistema de comunicação (essencialmente, mas não totalmente por meios não-linguísticos), que funciona como um mecanismo educacional formador dos hábitos das pessoas. Por sua vez, esses hábitos podem ajudar a desenvolver um complexo de capacidades e disposições, de virtudes civis (e cívicas), que podemos agrupar sob a rubrica de 'civilidade" ${ }^{\prime 243}$. O autor lista uma série de benfeitorias que podem ser alcançadas dentro desta perspectiva, como

fixa/telefonia celular) a 2011, o total de residências com algum tipo de telefone aumentou de 58,9\% a $89.9 \%$ (algo próximo a uma ideia de universalização razoável), sendo que o percentual de telefone fixo caiu de $51,1 \%$ para $40,1 \%$ e o de telefone celular aumentou de $7,8 \%$ para $49,7 \%$. Ainda que se admita alguma variação nos dados (já que foram excluídos os domicílios com ambos os sistemas, fixo e celular), é bastante confortável concluir que o avanço significativo de universalização da telefonia no Brasil veio do sistema móvel celular, explorado em regime privado. (fontes: www.ibge.gov.br e www.teleco.com.br)

${ }^{242}$ Cf. FARACO, Alexandre Ditzel, et al, Universalização das Telecomunicações: Uma Tarefa Inacabada, in Revista de Direito Público da Economia - RDPE, no 2, Belo Horizonte: Fórum, abr/jun 2003, página 35. Segundo estes autores, "[e]sta modalidade de contratação não exige que o consumidor pague uma assinatura mensal para ter o serviço disponível. $O$ usuário adquire um pacote de minutos, pagando-os antecipadamente. Isto permite-lhe controlar melhor os seus gastos, evitando situações de inadimplência, além de utilizar o telefone apenas para receber chamadas, o que não lhe trará qualquer custo. Um exemplo bastante marcante de difusão do serviço de telefonia móvel celular foi a migração para este de usuários dos serviços de radio chamada (pagers). Já em 1998, a Associação Brasileira de Radio chamada destacava que só naquele ano 120 mil usuários teriam trocado os pagers pelos telefones celulares (Cf. Pager Tenta Reagir ao Avanço do Celular. Gazeta Mercantil, 6 abr. 1999, p. C-3). Outro indicador da ampla difusão deste serviço entre a população mais carente é a substituição do telefone fixo (ou o suprimento da demanda por este) pelo celular. Segundo pesquisas feitas pela operadora Telesp Celular, $54 \%$ dos clientes pertencentes à classe D não têm telefone fixo em casa. Na classe C, são $23 \%$ os que possuem apenas o celular, e nas classes A/B, o percentual diminui a 5\% (Cf. Cresce Substituição do Fixo pelo Celular. Gazeta Mercantil, 16 dez. 2002, p. C-6).” (op. cit., página 35)

${ }^{243}$ Markets as Conversations: Markets' Contribution to Civility, the Public Sphere and Civil Society at Large, in PÉREZ-DÍAZ, Victor (ed.), Markets and Civil Society: The European Experience in Comparative Perspective, Nova Iorque: Berghahn Books, 2009, página 29. 
o desenvolvimento de capacidades cívicas, propiciar um acontability do Poder Público, limitar o processo político e monitorar a própria iniciativa privada ${ }^{244}$.

Enfim, não estamos aqui afirmando que a livre iniciativa sem balizas é melhor que um mercado regulado, que o papel do Estado é apenas evitar as falhas de mercado ou que mais liberdade traz mais benefícios. Não é isso. Apenas afirma-se que (i) os particulares são titulares legítimos de interesses públicos tuteláveis, (ii) que são ainda capazes de concretizá-los em alguns casos, (iii) não se mostrando razoável ou mesmo justificável tratá-los como agentes movidos unicamente pela cupidez.

\section{III.5. Afirmação da subsidiariedade no direito brasileiro: perspectivas teórica, constitucional e jurídico-administrativa}

Ultrapassando as críticas apresentadas, chega o momento de finalmente demonstrar a juridicidade da subsidiariedade como vetor objetivo de restrição da intervenção regulatória administrativa no domínio econômico. De nossa parte, é possível verificar e fundamentar a subsidiariedade, como limite a intervenção do Estado na economia, especialmente a intervenção regulatória administrativa, sob uma perspectiva teórica, constitucional e, ainda, jurídico-administrativa.

\section{III.5.1. Substrato teórico da subsidiariedade}

Do ponto de vista teórico, pelo visto até agora, nossa posição é de que há logicamente fundamento para se afirmar haver uma regra geral de subsidiariedade na intervenção do Estado nas liberdades públicas, que se irradia para o domínio econômico e em sede de regulação administrativa. Cabe aqui, portanto, rever o quanto arguido.

Em primeiro lugar, é preciso reconhecer que vai contra qualquer concepção de organização política da sociedade defender que o Estado existe para si mesmo, ou melhor, existe como um fim em si mesmo. Salvo melhor juízo, o Estado e as organizações estatais existem para satisfazer necessidades coletivas da sociedade, ou, como prefere Jorge MIRANDA, "para garantir segurança, fazer justiça, promover a

\footnotetext{
${ }^{244}$ Markets as Conversations, op. cit., páginas 61-69.
} 
comunicação entre os homens, dar-lhes paz e bem-estar e progresso. É um poder de decisão no momento presente, de escolher entre opções diversas, de praticar os actos pelos quais satisfaz generalizadas ou individualizadas das pessoas e dos grupos. É autoridade e é serviço" 245

Nesse contexto, o Estado nada mais é que uma abstração social, uma instituição imaterial criada e fruto da decisão consciente de cada indivíduo de abrir mão de parte da sua liberdade para outorgar a esse ente abstrato o poder de condução da vida em sociedade e de arbitramento dos interesses comuns ${ }^{246}$. Não se pretende aqui logicamente aprofundar o tema, o que, além de desnecessário, nem mesmo caberia no presente trabalho. Entretanto, é inegável reconhecer que a concepção que se tem do Estado é que este existe tão somente para nos servir, e não o contrário. Trata-se, em verdade, do mais importante aspecto epistemológico da decisão coletiva de se constituir um ente abstrato dotado de poder extroverso, o que garante que a figura estatal tenha sempre como função servir à sociedade, e não o contrário. Assim sendo, não seria coerente defender a possibilidade de o mesmo Estado-instrumento substituir os seus constituintes $^{247}$.

Daí a conclusão elementar de que que a atuação estatal somente se mostra legítima na ausência da própria sociedade. Ou seja, somente há espaço para a atuação do Estado e dos órgão da Administração Pública quando reconhecidamente há necessidade social, isto é, quando os próprios corpos sociais não demonstrem capacidade de implementar ou mesmo garantir as aspirações da coletividade. É, portanto, à luz de um critério de incapacidade dos indivíduos que surge a legitimidade da atuação estatal. Esta aí, pois, vincada na própria essência da figura estatal, o fundamento para se admitir a subsidiariedade como um limite à atividade e, igualmente, à intervenção estatal nas liberdades privadas.

\footnotetext{
${ }^{245}$ Teoria do Estado e da Constituição, op. cit., página 314.

${ }^{246}$ Para uma visão mais aprofundada dos fins do Estado ver BONAVIDES, Paulo, Teoria Geral do Estado, 8 a ed., São Paulo: Malheiros Editores, 2010, páginas 111-124.

${ }^{247}$ Mesmo Aristóteles, há mais de 2.300 anos, já reconhecia os riscos e a incoerência de se imaginar um Estado excessivo e autorreferencial. Dizia ele que "[e]xiste ainda um outro meio que vem demonstrar que a tendência exagerada para a unidade não é o que se pode desejar de melhor para o Estado. Uma família supre melhor a si mesma que um indivíduo, e um Estado melhor ainda que uma família. Ora,o Estado significa uma associação de homens que possuem o meio de suprir a sua existência. Se, pois, o que é mais capaz de suprir a si mesmo é o preferido, o que é menos não o será". (A Política, $2^{\mathrm{a}}$ ed., Bauru: Edipro, 2009, 1261b, 10-15, página 41).
} 
Neste viés, não se trata aqui de um confronto para saber o que deve prevalecer, se liberdade privada ou direitos sociais, se individualidade ou solidariedade, se liberalismo ou socialismo. Nada disso. Cuida-se apenas de reconhecer que a função estatal é subsidiária por natureza, porque o Estado e seus órgãos foram concebidos originalmente para suprir falhas sociais, para garantir o atingimento de interesses da coletividade (interesses públicos) cujos corpos sociais se mostraram incapazes. Ou seja, trata-se tão somente de admitir que "o Estado não existe em si ou por si; existe para resolver problemas da sociedade, quotidianamente" ${ }^{248}$.

O Estado, ressalta Chantal MILLON-DELSOL, é o resultado do reconhecimento das insuficiências dos cidadãos, e serve justamente para que a sociedade alcance projetos muito mais arrojados e eficientes, mas em hipótese alguma poderá substituir os seres humanos, se não por conta de uma natural propensão da autoridade de abusar do poder, certamente porque em um Estado de direito, o manejo do poder deve sempre estar vinculado a uma utilidade ${ }^{249}$. Se o Estado existe para auxiliar os indivíduos a alcançarem a satisfação de seus direitos de forma razoavelmente igualitária, então não faz muito sentido que esse mesmo Estado substitua os indivíduos nessa busca independentemente de sua suficiência. Significaria, no limite, aceitar que o Estado substitua os cidadãos na delimitação dos fins e na utilização dos meios para a vida em coletividade. E como bem lembra Paulo OTERO, "não é o Homem que existe para o Estado, antes é o Estado que existe para o Homem",250

Assim, de um ponto de vista que se pode chamar de teórico, a intervenção estatal no domínio econômico, inclusive no que toca à atividade regulatória administrativa, se relaciona com a iniciativa privada sob um critério de subsidiariedade. Ou seja, compete logicamente ao Poder Público definir quais fins de interesse público deverão ser implementados ou garantidos. Compete-lhe ainda implementá-los de todos os modos admitidos pela Constituição ao qual fizemos referência no Capítulo I. Entretanto, somente há espaço para a atuação estatal (intervenção, no caso) quando verificada a insuficiência ou incapacidade dos atores econômicos em garantir o atingimento de tais fins. Para além de ideologia vincada na velha dicotomia política

\footnotetext{
${ }^{248}$ Cf. MIRANDA, Jorge, Teoria do Estado e da Constituição, op. cit., página 314.

${ }^{249}$ L' État Subsidiaire, op. cit., páginas 223-224.

${ }^{250}$ Vinculação e Liberdade de Conformação Jurídica do Sector Empresarial do Estado, op. cit., página 34.
} 
clássica $^{251}$, o que se está a afirmar decorre da própria essência do aparato estatal, e traduz ainda em importantes diferenciações no plano jurídico, conforme será aprofundado mais adiante.

\section{III.5.2. Fundamentos constitucionais da subsidiariedade}

Não obstante o que se disse até agora, e tendo em vista a insubsistência das críticas acerca da ideologização da subsidiariedade e de sua suposta incapacidade de figurar no debate constitucional, importa aqui justamente tratar do substrato constitucional do que estamos a analisar. De todo modo, não custa repetir que a subsidiariedade não veda nem estimula a regulação, apenas predica um critério de incidência legítima da atividade regulatória da Administração Pública. Somente nesse sentido é que se pode compreender as observações de Vital MOREIRA ${ }^{252}$ e José Vicente Santos de CARVALHO ${ }^{253}$ segundo as quais mais ou menos intervenção estatal, mais ou menos regulação administrativa, mais ou menos liberdade empresarial dos cidadãos, são todas opções constitucionais e legislativas livres.

Com efeito, é possível identificar o vetor de subsidiariedade da regulação administrativa na economia de duas formas, ambas reciprocamente complementares e fundadas no reconhecimento da livre iniciativa como um direito fundamental dos indivíduos. É o que se passa a expor.

\footnotetext{
${ }^{251}$ Referimo-nos aqui à vetusta mas ainda existente díade direita e esquerda, que, como ensina Norberto BOBBIO, significa uma disputa entre igualdade e liberdade, não como uma dicotomia fechada e estanque, como quer Matteucci, mas no sentido de que, embora manejados pelos dois, a verdadeira disputa entre esquerda e direita repousa em atribuir mais estima à igualdade ou à diversidade. Para BOBBIO, o elemento que melhor caracteriza a esquerda é o igualitarismo, que funciona como tendência a exaltar mais o que faz os homens iguais do que o que os faz desiguais, ou seja, a favorecer políticas que objetiva a tornar mais iguais os desiguais. Por outro lado, a liberdade informa mais os ideais chamados de direita, ainda que a igualdade seja também essencialmente relevante. O próprio BOBBIO, entretanto, reconhece a existência de inúmeras matizes entre os dois extremos, as quais se dão pelas diferentes combinações possíveis de ideias. Sobre o tema ver Direita e Esquerda: razões e significações de uma distinção particular, $3^{\mathrm{a}}$ ed., São Paulo: UNESP, 2011, páginas 79-135.
}

${ }^{252}$ Cf. MOREIRA, Vital, Auto-Regulação Profissional e Administração Pública, op. cit., páginas 9899.

${ }^{253}$ Direito Constitucional Econômico, op. cit., página 263. 


\section{III.5.2.a. Livre iniciativa como direito fundamental}

Em primeiro lugar, parece-nos inegável que a Constituição Federal de 1988 elegeu a livre iniciativa como um direito fundamental dos indivíduos. De um lado porque o inciso XIII do artigo $5^{\circ}$ do Texto Constitucional estabelece que "é livre o exercício de qualquer trabalho, ofício ou profissão, atendidas as qualificações profissionais que a lei estabelecer". Reafirmando a diretriz, diz o parágrafo único do artigo 170 da Constituição ser "assegurado a todos o livre exercício de qualquer atividade econômica, independentemente de autorização de órgãos públicos, salvo nos casos previstos em lei".

Parece-nos inequívoco residir aí o fundamento para se reconhecer que a livre iniciativa é um direito fundamental, ou melhor, que existe um direito fundamental dos indivíduos (individualizados ou organizados como sociedades empresariais) de iniciar atividades econômicas como lhes convierem, nos termos do que predica a ordem jurídica. Bem é verdade que o Texto Constitucional trata da expressão "livre iniciativa" como fundamento da República brasileira (art. $1^{\circ}$, III) e da ordem econômica (art. 170). Isso, entretanto, não afasta a conclusão exposta, mas, ao contrário, reforça-a, já que denota a essencialidade da livre iniciativa na ordem jurídica, tornando mais sólida a garantia instituída. Sem contar que acaba dando unidade ao termo, sendo possível, mediante uma interpretação sistemática simples, falar em direito fundamental à livre iniciativa.

Assim, tem-se que a livre iniciativa é traduzida na liberdade de escolha e de livre exercício de atividade econômica, a qual encontra fundamento na autonomia pública e privada dos cidadãos, enquanto agentes morais, independentes e capazes de exercer livremente suas escolhas ${ }^{254}$. Engloba, pois, a capacidade dos particulares de, nos termos do sistema jurídico vigente, iniciar um ofício, organizar-se empresarialmente, obter lucro, competir por mercados, contratar e se apropriar do

${ }^{254}$ Cf., no mesmo sentido, BASTOS, Celso Ribeiro, Curso de Direito Constitucional, op. cit., páginas 314-315; ARAGÃO, Alexandre Santos de, Liberdade de Expressão Comercial, in Revista de Direito Público da Economia - RDPE, ano 3, no 11, Belo Horizonte: Fórum, jul/set. 2005, p. 36-37; ORTIZ, Gaspar Ariño, Principios de Derecho Público Econômico, op. cit., p. 255; MONCADA, Luis S. Cabral de, Direito Económico, 4a ed., Coimbra: Coimbra Editora, 2003, p. 117-125; VAZ, Manuel Afonso, Direito Económico: A Ordem Económica Portuguesa, 4a ed., Coimbra: Coimbra Editora, 1998, p. 167168. 
resultado obtido ${ }^{255}$. Como ensinava Celso Ribeiro BASTOS a respeito da livre iniciativa:

\begin{abstract}
"Na verdade esta liberdade é uma manifestação dos direitos fundamentais e no rol daqueles devia estar incluída. De fato o homem não pode realizar-se plenamente enquanto não lhe for dado o direito de projetar-se através de uma realização transpessoal, vale dizer, por meio da organização de outros homens com vistas à realização de um objetivo. Aqui a liberdade de iniciativa tem conotação econômica. Equivale dizer ao direito que todos têm de lançarem-se ao mercado da produção de bens e serviços por sua conta e risco. Aliás, os autores reconhecem que a liberdade de iniciar a atividade econômica implica a de gestão e a de empresa." 256
\end{abstract}

Nem de longe a tese aqui defendida constitui opinião isolada. $\mathrm{Na}$ doutrina brasileira, também compartilham deste entendimento ao menos Alexandre Santos de ARAGÃO ${ }^{257}$, André Rodrigues CYRINO ${ }^{258}$, Leonardo MARTINS ${ }^{259}$, Luciano Benetti TIMM ${ }^{260}$ e Francisco dos Santos AMARAL NETO ${ }^{261}$. No direito português é possível falar de Vital MOREIRA ${ }^{262}$, Cabral de MONCADA ${ }^{263}$, Jorge MIRANDA ${ }^{264}$, Manuel Afonso VAZ $^{265}$ e António Menezes CORDEIRO ${ }^{266}$. Já no direito espanhol tem-se a opinião de Cândido Paz-Ares RODRÍGUES e Jesús Alfaro

255 Cf. MOREIRA NETO, Diogo de Figueiredo, Ordem Econômica e Desenvolvimento na Constituição de 1988, op. cit., página 27.

${ }^{256}$ BASTOS, Celso Ribeiro e MARTINS, Ives Gandra, Comentários à Constituição do Brasil, v. 7, São Paulo: Saraiva, 1990, página 16.

${ }^{257}$ Liberdade de Expressão Comercial, op. cit., páginas 36-37.

${ }^{258}$ Direito Constitucional Regulatório, op. cit., páginas 61-64.

${ }^{259}$ Liberdade e Estado Constitucional, São Paulo: Atlas, 2012, páginas 159-166.

${ }^{260}$ O Direito Fundamental à Livre Inciativa, in O Novo Código Civil, Porto Alegre: Livraria do Advogado, 2008, páginas 104-106.

${ }^{261}$ A liberdade de iniciativa econômica: fundamento, natureza e garantia constitucional, in Revista de Informação Legislativa, v. 23, n 92, Brasília: Senado Federal, out/dez 1986, páginas 230-237.

${ }^{262}$ A Ordem Jurídica do Capitalismo, op. cit., páginas 162-169.

${ }^{263}$ Direito Económico, op. cit., páginas 117-125.

${ }^{264}$ Iniciativa Económica, in Escritos Vários sobre Direitos Fundamentais, Estoril: Princípia Editora, 2006, páginas 179-183.

${ }^{265}$ Direito Económico, op. cit., páginas 167-168.

${ }^{266}$ Concorrência e direitos e liberdades fundamentais na União Européia, in ALBUQUERQUE, Ruy de e CORDEIRO, António Menezes (coords.), Regulação e Concorrência: perspectivas e limites da defesa da concorrência, Coimbra: Almedina, 2005, páginas 11-14. 
ÁGUILA-REAL ${ }^{267}$, bem como a de Gaspar Ariño ORTIZ ${ }^{268}$. Na doutrina italiana são referência as opiniões de Aldo M. SANDULLI ${ }^{269}$, Francesco SCAGLIONE $^{270}$ e Egidio TOSATO ${ }^{271}$, entre outros.

Da mesma forma, não se poderia alegar a inviabilidade da titularização de direitos fundamentais por pessoas jurídicas ${ }^{272}$, o que teoricamente neutralizaria a constatação de um direito fundamental à livre iniciativa privada amplo (exercido fundamentalmente por empresas). Ora, admitir tal concepção seria ignorar que tanto os direitos fundamentais como o agrupamento dos indivíduos e sua respectiva organização e reconhecimento como pessoas coletivas resulta de uma resposta jurídica a situações sociais concretas. E é precisamente o reconhecimento dessa realidade que surge a determinação de se outorgar às sociedades empresariais as proteções concretas e direitos fundamentais devidos originalmente aos indivíduos ${ }^{273}$. Quanto mais não fosse porque em termos econômicos, os indivíduos, vistos de forma isolada, têm efetivamente relevância limitada no contexto atual, já que grande parte das relações econômicosociais são travadas por pessoas físicas ${ }^{274}$. Daí a conclusão de que os direitos fundamentais compatíveis com sua natureza são logicamente titularizados também pelas pessoas jurídicas, como a livre iniciativa, o direito de resposta, a liberdade de associação, o sigilo da correspondência, a propriedade, a liberdade de iniciativa, etc. (à exceção daqueles que naturalmente estão ligados de forma direta às pessoas, como a vida e a integridade física, por exemplo ${ }^{275}$ ), o que, de resto, configura tema pacífico na doutrina $^{276}$.

\footnotetext{
${ }^{267}$ Artículo 38, in BAHAMONDE, Maria Emilia Casas e BRAVO-FERRER, Miguel Rodríguez-Piñero y (orgs.), Comentarios a la Constitución Española, Madrid: Fundación Wolters Kluwer, 2008, páginas 991-992.

${ }^{268}$ Principios de Derecho Público Econômico, op. cit., página 255.

${ }^{269}$ Manuale di Diritto Amminitrativo, Napoli: Jovene, 1964, página 81.

${ }^{270}$ Il mercato e le regole della correttezza, Padova: Wolters Kluwer Italia, 2010, página 73.

${ }^{271}$ Persona, Società Intermedie e Stato, op. cit., páginas 96-97.

${ }^{272}$ Como faz GRAU, Eros Roberto, A Ordem Econômica na Constituição de 1988, op. cit., páginas 207-208.

${ }^{273}$ Cf. IGLESIAS, Gema Rosado, La titularidad de derechos fundamentales por la persona jurídica, Valência: Tirant Lo Banch, 2004, paginas 97-137.

${ }^{274}$ Cf. ARAGÃO, Alexandre Santos de, Liberdade de Expressão Comercial, op. cit., páginas 34-35.

${ }^{275}$ Como diz-nos Gomes CANOTILHO: “As pessoas colectivas gozam de direitos fundamentais como, por exemplo, a liberdade de imprensa, a liberdade de reunião, a liberdade de profissão, a liberdade de domicílio, devendo, no entanto, neste âmbito de direitos fundamentais extensivos às pessoas colectivas,
} 
Por outro lado, é relevante notar ainda que o fato de a Constituição Federal ter elencado a "valorização do trabalho humano" e os "valores sociais do trabalho" também como fundamentos da Republica e da ordem econômica brasileira não afasta ou mesmo fragiliza o reconhecimento da livre iniciativa como um direito fundamental constitucionalmente garantido. É que não há muito sentido em não considerar a livre iniciativa e a valorização do trabalho humano como conceitos ao menos em tese convergentes (afinal, a livre inciativa é um modo de se expressar o próprio trabalho), sob pena de se incorrer em uma tautologia, a de que somente se garante a valorização do trabalho mediante a atuação estatal. Com isso, dois problemas fundamentais exsurgem: $(\boldsymbol{i})$ de um lado, adota-se postura ideologicamente contaminada, segundo a qual é preferível a intervenção estatal para garantir a valorização do trabalho; (ii) em segundo lugar, incorre-se novamente em considerar a atuação privada com notável desconfiança, como se os particulares fossem incapazes de produzir o bem sem a condução estatal.

De todo modo, parece correta a afirmação de Floriano de Azevedo MARQUES NETO no sentido de que "[o] máximo que se pode extrair do fundamento da valorização do trabalho humano é o fato de que toda a iniciativa econômica, privada e pública, está submetida às formas de intervenção estatal promotoras da valorização laboral (normas de proteção do trabalho, regras limitadoras de jornada, poder de polícia das relações de trabalhistas, fomento à geração de empregos, proteção do meio ambiente do trabalho e da saúde do trabalhador etc.)"277. Ou seja, funciona a valorização do trabalho humano como uma limitação ao direito fundamental de livre iniciativa dos indivíduos e também à iniciativa econômica estatal (direta ou

verificar-se, caso a caso, se o domínio da norma é aplicável às pessoas jurídicas." (Direito Constitucional e Teoria da Constituição, op. cit., página 421)

${ }^{276}$ Além dos autores já citados, cf. SILVA, José Afonso, Curso de Direito Constitucional Positivo, op.

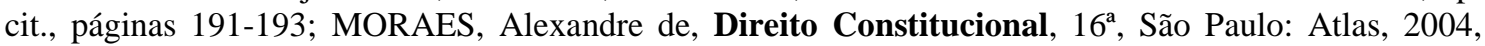
página 65; MENDES, Gilmar Ferreira et. al., Curso de Direito Constitucional, op. cit., páginas 303-304; TAVARES, André Ramos, Curso de Direito Constitucional, op. cit., página 497; BASTOS, Celso Ribeiro, Curso de Direito Constitucional, op. cit., página 284-285; SCHMITT, Cristiano Heineck, A Invocação dos Direitos Fundamentais no Âmbito das Pessoas Coletivas de Direito Privado, in Revista de Informação Legislativa, ano 37, $\mathrm{n}^{\circ}$ 145, Brasília: Senado Federal, jan/mar 2000, páginas 55-70; BINENBOJM, Gustavo, Agências Reguladoras, Legalidade e Direitos Fundamentais - Limites aos Poderes Normativo e Sancionatório da Anvisa na Regulação de Produtos Fumígenos, in ARAGÃO, Alexandre Santos de (org.), O Poder Normativo das Agências Reguladoras, Rio de Janeiro: Forense, 2006, página 658. No STF, veja-se a decisão proferida na MC AC 2395/PB, Rel. Min. Joaquim Barbosa, DJe de 04.02.2009.

${ }^{277}$ O Fomento como Instrumento de Intervenção Estatal na Ordem Econômica, op. cit., página 60. 
interventiva, inclusive regulatória), no sentido de somente poder ser plenamente exercido se respeitador das diretrizes de valorização laboral.

Aliás, uma incisiva crítica é feita quanto à existência do direito fundamental à livre iniciativa com base no mesmo equívoco. Nesse sentido, anota Gilberto BERCOVICI que em sua concepção a livre iniciativa não é um direito fundamental, mas sim uma liberdade pública, já que a própria Constituição não a garante em termos absolutos, uma vez que também foi previsto seu valor social ${ }^{278}$. Já Eros GRAU anota que a "liberdade de iniciativa econômica é liberdade pública precisamente ao expressar não sujeição a qualquer restrição estatal senão em virtude de lei" ${ }^{\prime 279}$.

De nossa parte, com a devida vênia e sem discordar completamente desses autores, temos que os argumentos expendidos parecem estar certos e errados ao mesmo tempo. Certos na conclusão, mas equivocados na premissa.

Com efeito, embora os conceitos de direito fundamental e liberdade pública não sejam sinônimos (mas sim complementares em alguma medida), fica claro que a preocupação dos referidos autores reside em afastar uma concepção supostamente ilimitável dos direitos fundamentais. Justamente por isso que Gilberto BERCOVICI alega não cuidar a livre iniciativa de um direito subjetivo público, mas uma liberdade pública conformada pela ordem constitucional ${ }^{280}$. Ora, encontra-se justamente aí o equívoco, já que conforme vimos acima, em termos de delimitações dos direitos fundamentais é possível falar em duas teorias predominantes, a interna e a externa. Ambas, entretanto, admitem logicamente limitações aos direitos fundamentais (já que a ideia de direitos absolutos, como se viu, é insustentável), sendo que a única diferença é que a teoria interna trabalha com o conceito de limites imanentes, ou seja, limitações internas ao direito; ao passo que a teoria externa parte do pressuposto que limitações aos direitos fundamentais são não apenas possíveis, mas certamente desejáveis para dar-lhe a verdadeira concretude.

É logicamente com a teoria externa que coadunamos, a qual divide seu objeto de estudo em dois: o direito fundamental prima facie, ou seja, visto sob a

\footnotetext{
${ }^{278}$ Direito Econômico do Petróleo e dos Recursos Minerais, op. cit., página 263.

${ }^{279}$ A Ordem Econômica na Constituição de 1988, op. cit., página 205.

${ }^{280}$ Direito Econômico do Petróleo e dos Recursos Minerais, op. cit., página 263.
} 
perspectiva de um âmbito de proteção amplíssimo, em que se inclui tudo aquilo que milita a favor do direito em questão (no caso, uma liberdade econômica extremamente ampla e alargada, que configura justamente o receio dos autores citados); e, destacadamente, suas restrições, ou seja, todos os outros direitos fundamentais e valores constitucionais cujo âmbito de proteção militem contra a concepção ampla do direito fundamental a ser restringido. Como observa Robert ALEXY, "[r]estringíveis são os bens protegidos por direitos fundamentais (liberdades/situações/posições de direito ordinário) e as posições prima facie garantidas por princípios de direitos fundamentais" $^{281}$.

Pois para a configuração do direito fundamental de forma concreta, absolutamente essencial que se proceda a uma ponderação entre os direitos/valores teoricamente contraditórios para se chegar ao seu conteúdo verdadeiro. No caso, trata-se de contrastar um suporte amplo de livre iniciativa (o qual inclui todas as possibilidades imagináveis do direito, de forma absolutamente ampla) com os valores a serem protegidos no caso concreto (que se supõem serem fundados nos valores da ordem econômica estabelecidos no artigo 170 da Constituição). Desse processo de ponderação, balizado pela proporcionalidade, é que se chegará à imagem concreta da livre iniciativa no caso prático.

Assim, reitere-se que não há muito sentido em se combater um suposto caráter absoluto da livre iniciativa como direito fundamental, já que direitos absolutos e irrestringíveis não existem, o que transforma o tratamento da livre iniciativa como liberdade pública um mero jogo de palavras.

Por outro lado, a distinção feita entre direito e liberdade se mostra igualmente falha, já que ambígua e incapaz de produzir resultados práticos. Veja-se, sob a pecha de liberdade pública como direito passível de limitação externa também poderiam ser incluídas a liberdade de ir e vir, a liberdade de manifestação do pensamento, a liberdade de associação, a liberdade de expressão da atividade intelectual, artística, científica e de comunicação: todos direitos fundamentais expressos na Constituição Federal e que são passíveis de limitação em alguma medida. De todo modo, parece-nos que defender a tese de que a livre iniciativa é uma liberdade pública

\footnotetext{
${ }^{281}$ Teoria dos Direitos Fundamentais, op. cit., página 281.
} 
funciona como um mecanismo de defesa contra algo que na verdade não existe, vale dizer, direitos supostamente absolutos ${ }^{282}$.

E é justamente daí decorre o acerto das teses dos autores acima mencionados, a de que são logicamente admissíveis restrições à livre iniciativa em função do regime jurídico existente. Em outras palavras, é justamente em virtude do ordenamento jurídico existente, com as exigências e regulamentações impostas pelo Poder Público que se torna possível falar em livre iniciativa. Ou seja, é do resultado da ponderação entre livre iniciativa e demais direitos ou valores constitucionais que se extrai o conteúdo prático do direito, ou melhor, que se torna possível dar concretude ao direito fundamental da livre iniciativa. Após, portanto, a ponderação da livre iniciativa com os valores insculpidos no artigo 170 da Constituição Federal à luz do caso prático é que haverá a configuração efetiva do conteúdo desse direito fundamental. Embora sem utilizar explicitamente esse itinerário, não outra é a conclusão de José Afonso da SILVA:

"A atividade econômica, no regime capitalista, como é o nosso, desenvolvese no regime da livre iniciativa sob a orientação de administradores da empresa privada. É claro que, consoante já vimos, numa ordem econômica destinada a realizar a justiça social, a liberdade de iniciativa econômica privada não pode significar mais do que liberdade de desenvolvimento da empresa no quadro estabelecido pelo Poder Público. É, sim, um direito fundamental, enquanto exercido no interesse da realização da justiça social, da valorização do trabalho e do desenvolvimento nacional." 283

Partindo, pois, da concepção da livre iniciativa como um direito fundamental dos indivíduos, é possível constar o vetor de subsidiariedade da intervenção regulatória da Administração Pública sob duas fórmulas, adiante aprofundadas.

\footnotetext{
${ }^{282}$ Intuitivo deste posicionamento é a decisão do STF proferida no MS 23.452/RJ, segundo a qual " $O S$ DIREITOS E GARANTIAS INDIVIDUAIS NÃO TÊM CARÁTER ABSOLUTO. Não há, no sistema constitucional brasileiro, direitos ou garantias que se revistam de caráter absoluto, mesmo porque razões de relevante interesse público ou exigências derivadas do princípio de convivência das liberdades legitimam, ainda que excepcionalmente, a adoção, por parte dos órgãos estatais, de medidas restritivas das prerrogativas individuais ou coletivas, desde que respeitados os termos estabelecidos pela própria Constituição." (Rel. Ministro Celso de Mello, DJ de 12.05.2000)
}

${ }^{283}$ Curso de Direito Constitucional Positivo, op. cit., página 801. 


\section{III.5.2.b. Fórmula 1: inexistência de um direito da Administração Pública de intervir na economia}

A primeira forma de se constatar o substrato constitucional da subsidiariedade como limite à intervenção estatal regulatória na economia reside em uma observação que, de tão simples, chega a ser quase acaciana: ora, se de um lado há um direito fundamental dos particulares a livre iniciativa na economia, de outro não se pode falar em direito do Estado de intervir no domínio econômico. Há logicamente uma série de valores constitucionais e direitos fundamentais e transindividuais que compete ao Estado resguardar por meio da intervenção direta ou indireta, mas em termos de direitos, absolutamente nada autoriza o Poder Público a ter um direito de intervir suficiente em si.

Direitos fundamentais, como é sabido, são garantias dos indivíduos contra o arbítrio estatal, o que levaria a se cogitar a Administração invocando garantias contra ela mesma. Entretanto, é também cediço que esses direitos evoluíram consideravelmente ao passar dos tempos, ao ponto de se tornarem de tal modo complexos que hoje não seria estranho garantir parte deles até mesmo a pessoas jurídicas de direito público. Basta imaginar uma Administração postulando em juízo e fazendo jus à tutela judicial e, nesse contexto, também ao contraditório e à ampla defesa. Há inclusive precedente do STF reconhecendo a possibilidade de Municípios se valendo do direito fundamental de impetrar mandado de injunção em casos de omissão legislativa patente ${ }^{284}$. Entretanto, imaginar um direito fundamental do Estado de intervir na economia implica em considerá-lo o próprio beneficiário da intervenção, o que configuraria um despropósito.

Daí porque conceber a intervenção estatal que restringe em alguma medida a livre iniciativa dos particulares como uma garantia institucional. Nesse

\footnotetext{
${ }^{284}$ Referimo-nos aqui ao MI 725/RO, em que o Ministro Relator Gilmar Mendes se manifestou obre o tema da seguinte forma: "Não se deve negar aos Municípios, peremptoriamente, a titularidade de direitos fundamentais e a eventual possibilidade de impetração das ações constitucionais cabíveis para sua proteção. Se considerarmos o entendimento amplamente adotado de que as pessoas jurídicas de direito público podem, sim, ser titulares de direitos fundamentais, como, por exemplo, o direito à tutela judicial efetiva, parece bastante razoável vislumbrar a hipótese em que o Município, diante de omissão legislativa do exercício desse direito, se veja compelido a impetrar mandado de injunção. A titularidade de direitos fundamentais tem como consectário lógico a legitimação ativa para propor ações constitucionais destinadas à proteção efetiva desses direitos." (Tribunal Pleno, DJe de 20.09.2007)
} 
sentido, conforme anota Jorge MIRANDA, a livre iniciativa privada revela a autonomia de pessoas e de grupos formados na sociedade perante o Estado, tendo como o cerne de sua estrutura sua própria atividade. "Por isso, naturalmente, a iniciativa pública, ligada à realização do interesse geral e quase sempre ao exercício de poderes de autoridade, apenas pode ser uma garantia institucional, nunca um direito fundamental $^{\prime 285}$. Nem mesmo Cabral de MONCADA, que admite pautas interventivas bastante livres, defende cuidar a intervenção estatal de um direito fundamental. Conforme aponta o autor:

"[O] direito de livre iniciativa dos poderes públicos não é um direito subjectivo à semelhança da iniciativa privada e cooperativa. Trata-se de um poder dever ou de uma competência, pelo que só existe se e na medida em que a Constituição o proteja e o alimente." 286

Aliás, impossível deixar de notar que o próprio termo 'direito estatal' soa equívoco, já que é sabido que o Estado possui competências, funções, deveres e prerrogativas, não direitos. De todo modo, o que importa aqui é notar que o fato de a Constituição Federal instituir um direito fundamental à livre iniciativa não justifica logicamente falar-se em um direito estatal de intervir, muito menos em um direito fundamental interventivo (o que soaria ainda mais estranho). Da mesma forma, não se pode daí concluir que haveria uma liberdade privada ilimitável. Ao contrário, há ampla competência estatal para intervir na economia e garantir os deveres e valores por ela tutelados. O que nos parece resultar do fato de a Constituição Federal ter garantido o direito fundamental à livre iniciativa é tão somente a instituição da obrigatoriedade de que qualquer intervenção estatal, que se pretenda legítima, considere que a economia é espaço natural dos cidadãos.

É dizer, o direito fundamental à livre iniciativa acaba por legitimar do ponto de vista constitucional o substrato teórico acima visto de que a economia é espaço natural dos indivíduos. Ou seja, a própria Constituição Federal garante o direito dos atores privados de (respeitados logicamente os regramentos jurídicos vigentes) iniciar qualquer trabalho, ofício ou profissão, negócio, produção (e sua gestão), contrato, consumo, etc., o que implica em lhes reconhecer como os verdadeiros e naturais agentes

\footnotetext{
${ }^{285}$ Iniciativa Económica, op. cit., página 179.

${ }^{286}$ Direito Económico, op. cit., página 193.
} 
do mercado. O Estado, embora tenha papel absolutamente fundamental, age como um ator externo, que justamente intervém para garantir resultados (tutelar direitos, defender valores, etc.) que o próprio setor econômico não conseguiria afiançar à coletividade. É justamente com essa conotação que compreendemos a afirmação de Caio TÁCITO segundo a qual, não obstante todas as modulações de regimes intervencionistas ao longo dos anos, "subsiste o sistema de sociedade aberta e de economia de mercado, que é de nossa tradição política, no qual a iniciativa econômica pública é, por definição constitucional, complementar da iniciativa privada, obedecendo ao princípio da subsidiariedade, 287 .

Daí, pois, o acerto das palavras de Egon Bockmann MOREIRA:

"Não há dúvida de que a intervenção significa adentrar em ambiente econômico alheio àquele do interveniente (formal ou substancialmente diverso), com a finalidade de o modificar - dirigindo ou influindo sobre o seu desenvolvimento, a fim de produzir resultados econômicos diferentes daqueles que porventura o seriam caso não se desse a intervenção. (...) No campo da intervenção pública na economia privada, trata-se de adentrar na atividade econômica reservada pela Constituição à livre iniciativa, liberdade de empresa e livre concorrência." 288

\section{III.5.2.c. Fórmula 2: livre iniciativa como direito fundamental, ponderação, proporcionalidade e subsidiariedade}

Por outro lado, é possível ainda reconhecer o caráter subsidiário da intervenção regulatória exercida pela Administração Pública pela simples ponderação entre a livre iniciativa vis a vis os direitos e valores a serem tutelados pela própria intervenção. Ou seja, quer nos parecer que a própria ponderação da livre iniciativa (um direito fundamental, vimos) com os demais valores eventualmente com ela conflitantes já traduz a natureza subsidiária da atividade regulatória administrativa (como de resto qualquer intervenção estatal na economia).

\footnotetext{
${ }^{287}$ O Retorno do Pêndulo: Serviço Público e Empresa Privada. O Exemplo Brasileiro, in Revista de Direito Administrativo - RDA, no 202, Rio de Janeiro: FGV, out/dez 1995, página 3.

${ }^{288}$ O Direito Administrativo da Economia, a Ponderação de Interesses e o Paradigma da Intervenção Sensata, op. cit., página 84.
} 
Nesse sentido, embora não caiba aqui aprofundar, deve-se ter em mente que o critério ponderativo, ainda que de certa forma vulgarizado nos dias atuais, funciona como uma espécie de valoração simultânea de dois ou mais vetores com o objetivo de encontrar um equilíbrio, um contrapeso adequado que garanta a satisfação de cada um na melhor medida possível. Em hermenêutica, a ponderação aparece logo após a subsunção ${ }^{289}$, com a finalidade justamente de solucionar conflitos normativos que envolvam valores em tensão, não resolvíveis logicamente pelos mecanismos hermenêuticos tradicionais ${ }^{290}$. Assim, pondera-se normas que predicam que algo deva ser realizado na maior medida possível, ou seja, direitos, princípios, valores, interesses e bens jurídicos ${ }^{291}$.

Entretanto, foi justamente com o tema dos direitos fundamentais e dos princípios (os quais, de resto, têm estrutura aplicativa idêntica) que a ideia de ponderação ganhou maior relevância. Para o presente estudo, o tema da ponderação interessa porquanto, conforme visto à exaustão acima, a intervenção regulatória administrativa restringe a livre iniciativa para a garantia de outros valores jurídicos. Nesse sentido, segundo propõe Ana Paula de BARCELLOS, a ponderação deve ser fragmentada em três etapas consecutivas:

"Na primeira delas, caberá ao intérprete identificar todos os enunciados normativos que aparentemente encontram-se em conflito ou tensão $e$ agrupá-los em função da solução normativa que sugerem para o caso concreto. A segunda etapa ocupa-se de apurar os aspectos de fato relevantes e sua repercussão sobre as diferentes soluções indicadas pelos grupos formados na etapa anterior. A terceira fase é o momento da decisão: qual das soluções deverá prevalecer? E por quê? Qual a intensidade da restrição a ser imposta às soluções preteridas, tendo em conta a produção da concordância prática de todos os elementos normativos em jogo?"292

\footnotetext{
${ }^{289}$ A ideia de ponderação como método hermenêutico, como se sabe, não é nova. Tem origem na chamada jurisprudência dos interesses de Ihering e Heck, ganhando maior assento na 'jurisprudência de valoração', oportunidade em que recebeu a contribuição do procedimento argumentativo e da busca pela justiça. Sobre o tema ver as críticas de LARENZ, Karl, Metodologia da Ciência do Direito, $3^{\mathrm{a}}$ ed., Lisboa: Fundação Calouste Gulbenkian, 1997, páginas 163-172.

${ }^{290}$ Cf. BARCEllos, Ana Paula de, Ponderação, Racionalidade e Atividade Jurisdicional, Rio de Janeiro: Renovar, 2005, página 23.

${ }^{291}$ Cf. RODRÍGueZ DE SAntiago, José María, La Ponderación de Bienes e Intereses en el Derecho Administrativo, Madri: Marcial Pons, 2000, páginas 55-58.

${ }^{292}$ Ponderação, Racionalidade e Atividade Jurisdicional, op. cit., página 92.
} 


\section{Em sentido semelhante, José María RODRÍGUEZ DE SANTIAGO}

aponta que as etapas da ponderação realizada pela Administração em casos que envolvem competências amplas e restrições aos direitos de liberdade dos cidadãos se dão (i) pela identificação dos interesses em jogo, seguida (ii) da atribuição de peso ou importância a cada um deles em atenção às circunstâncias do caso concreto e, por fim, (iii) da decisão de prevalência conforme o que chama de 'lei da ponderação' ${ }^{293}$.

Não obstante essas etapas, anota ainda a doutrina que a decisão final da ponderação deve também atender logicamente a um critério de proporcionalidade ${ }^{294}$. Em verdade, ínsito à ideia de ponderação de direitos contrapostos está a noção de que tais elementos devem ser simultaneamente restringidos na exata medida da garantia dos interesses buscados, com a finalidade de alcançar a maximização ideal dos valores ou direitos em jogo. Restrições excessivas ou insipientes são certamente inadmitidas pelo direito $^{295}$. Nesse sentido, a busca pela concretude da proporcionalidade deu fundamento à sua subdivisão nos hoje já amplamente conhecidos três elementos, vale dizer, a adequação, a necessidade e a proporcionalidade em sentido estrito. Assim, e sem desviar do essencial, é sabido que sempre que existir uma medida concreta destinada a realizar um fim, deve-se analisar a possibilidade dessa medida levar à realização pretendida (adequação), de a medida ser a menos restritiva aos direitos e interesses envolvidos (necessidade) e de a finalidade pública buscada ser valorosa a ponto de justificar a restrição imposta (proporcionalidade em sentido estrito) ${ }^{296}$.

\footnotetext{
${ }^{293}$ Ponderación y Actividade Planificadora de la Administración, in ORTEGA, Luis e SIERRA, Susana de la (coords.), Ponderación y Derecho Administrativo, Madrid: Marcial Pons, 2009, páginas 118-122.

${ }^{294}$ Cf. SARMENTO, Daniel, Os Princípios Constitucionais e a Ponderação de Bens, in TORRES, Ricardo Lobo, Teoria dos Direitos Fundamentais, $2^{\text {a }}$ ed., Rio de Janeiro: Renovar, páginas 57-62; JIMÉNEZ, Luis Arroyo, Ponderación, Proporcionalidad y Derecho Administrativo, in ORTEGA, Luis e SIERRA, Susana de la (coords.), Ponderación y Derecho Administrativo, op. cit., páginas 32-42; RODRÍGueZ DE SANTIAGO, José María, La Ponderación de Bienes e Intereses en el Derecho Administrativo, op. cit., páginas 105-111.

${ }^{295}$ Como anotam Ingo Wolfgang SARLET e Heinrich SCHOLLER "o princípio da proporcionalidade apenas pode ser tido como transgredido quando as sequelas negativas oriundas de determinada medida interventiva estiverem visivelmente em desproporção com o objetivo almejado, isto é, quando se verificar uma inequívoca disparidade. Da mesma forma que a administração não pode deixar de pautar sua atuação pelo princípio da proporcionalidade, também não poderá ela ir além das exigências deste postulado. A administração, portanto, também age de forma antijurídica quando o princípio da proporcionalidade acaba por ser superestimado e a administração, em virtude disso, deixar de tomar medidas necessárias". (O princípio da proporcionalidade no direito constitucional e administrativo da Alemanha, in Interesse Público, ${ }^{\circ}$ 2, Belo Horizonte: Fórum, abr/jun 1999, página 105)

${ }^{296}$ A bibliografia sobre o tema é amplíssima, tanto na doutrina estrangeira como na nacional. Nesse sentido, cf. BONAVIDES, Paulo, Curso de Direito Constitucional, op. cit., páginas 396-398; BARROSO, Luís Roberto, Interpretação e Aplicação da Constituição, 7 a ed., São Paulo: Saraiva, 2009,
} 
Interessa-nos aqui especificamente o segundo teste, vale dizer, o da necessidade. Com efeito, para que uma intervenção estatal seja necessária segundo esse critério, dentre todas as possíveis medidas teoricamente aptas a atingir os fins buscados (enquadráveis, pois, no primeiro critério da adequação), ela deve obrigatoriamente representar a menor onerosidade possível ao direito restringido. Ou seja, "de todas as medidas que igualmente servem à obtenção de um fim, cumpre eleger aquela menos nociva aos interesses do cidadão, podendo assim o princípio da necessidade (Erforderlichkeit) ser também chamado princípio da escolha mais suave"297.

Ora, quer nos parecer que o critério da necessidade representa justamente a faceta da subsidiariedade da intervenção estatal que estamos a aqui tratar. É que ao buscar a medida que menos restringe o direito ou interesse envolvido, o Poder Público necessariamente deve perquirir e levar em conta as capacidades dos agentes privados. De outro modo, sem manejar os reais potenciais dos atores privados em efetivamente implementar as pautas públicas que fundamentam as pretensões regulatórias da Administração, simplesmente não há como se adotar a medida que menos restrinja os direitos envolvidos. Em outras palavras, para ser necessária dentro de um critério de proporcionalidade a intervenção regulatória da Administração Pública deve respeitar o critério da subsidiariedade.

Justamente nesse sentido se posiciona Alexandre Santos de ARAGÃO:

"Inserto no Princípio da Proporcionalidade, mais especificamente em seu
elemento necessidade (...), está o Princípio da Subsidiariedade, que, na
seara do Direito Econômico, impõe ao Estado que se abstenha de intervir e
de regular as atividades que possam ser satisfatoriamente exercidas ou
auto-reguladas pelos particulares em regime de liberdade. Ou seja, na
medida que os valores constitucionalmente assegurados não sejam
prejudicados, o Estado não deve coarctar a liberdade dos agentes

páginas 234-235 (muito embora este autor trate da proporcionalidade e da razoabilidade como institutos similares, distinguindo-os apenas no que toca a sua origem); CANOTILHO, J. J. Gomes, Direito Constitucional e Teoria da Constituição, op. cit., páginas 266-270; SILVA, Virgílio Afonso da, $O$ Proporcional e o Razoável, op. cit., páginas 34-38; ÁVILA, Humberto, Teoria dos Princípios - da definição à aplicação dos princípios jurídicos, $9^{\mathrm{a}}$ ed., São Paulo: Malheiros Editores, 2009, páginas 165-173.

${ }^{297}$ Cf. BONAVIDES, Paulo, Curso de Direito Constitucional, op. cit., página 397. 
econômicos e, caso seja necessário, deve fazê-lo da maneira menos restritiva possivel." 298

Embora haja quem defenda que em termos de intervenção estatal no domínio econômico proporcionalidade e subsidiariedade não se confundam e sirvam a propósitos diferentes ${ }^{299}$, de nossa parte, a proporcionalidade funciona mesmo como um complemento à subsidiariedade: tanto $(\boldsymbol{i})$ a não intervenção em áreas cujos objetivos buscados podem ser alcançados autonomamente pelos atores privados como (ii) a intervenção proporcional à suficiência parcial do mercado são partes de um mesmo critério de respeito à livre iniciativa e à autonomia da sociedade. Em outras palavras, as opções estatais acerca de mais ou menos intervenção e aonde intervir devem ter como fundamento de legitimidade a capacidade de implementação de pautas públicas do setor econômico, o que remete à ideia de subsidiariedade aqui defendida. Logo, proporcionalidade e subsidiariedade configuram, a nosso ver, temas que se relacionam em grande medida ${ }^{300}$.

Portanto, como um dos fundamentos jurídicos constitucionais à subsidiariedade como limite à intervenção regulatória administrativa encontra-se justamente a proporcionalidade, notadamente o elemento da necessidade, que predica como critério de legitimidade que a restrição ao direito fundamental à livre iniciativa seja, dentre as opções válidas, o menos oneroso possível aos agentes privados. E isso não por uma questão de cordialidade ou deferência, mas sim porque exige a ordem jurídica em termos de legitimidade da atuação estatal.

\footnotetext{
${ }^{298}$ O Princípio da Proporcionalidade no Direito Econômico, in Revista de Direito Administrativo, ${ }^{\circ}$ 223, Rio de Janeiro: Renovar, jan/mar 2001, página 210.

${ }^{299}$ É o caso, por exemplo, de Floriano de Azevedo MARQUES NETO, que diferencia a subsidiariedade, que configura um limite à abrangência da intervenção regulatória, da proporcionalidade, que é tratada como um limite à intensidade da regulação (Limites à Abrangência e à Intensidade da Regulação Estatal, op. cit., páginas 79-92)

${ }^{300}$ Embora tratando do direito comunitário, afirma Maria do Rosário VILHENA que "subsidiariedade e proporcionalidade, muito embora sejam questões distintas e autónomas, estão intimamente associadas, e são suscitadas usualmente no âmbito de um mesmo debate, a saber, o relativo ao exercício das competências comunitárias". (O Princípio da Subsidiariedade no Direito Comunitário, op. cit., página 158)
} 


\section{III.5.3. Fundamento jurídico-administrativo da subsidiariedade}

Toda essa noção até agora vista sobre a subsidiariedade e seu fundamento constitucional funciona, em verdade, como um critério de condição-limite, já que decorrente da livre iniciativa dos particulares e de suas consequências. Entretanto, há ainda uma segunda forma de ver as coisas, relacionada à existência de uma regra de competência que autorize a intervenção regulatória da Administração na economia, o que traduz um critério de condição-fundamento da subsidiariedade ${ }^{301}$.

Com efeito, referimo-nos aqui à acima mencionada perspectiva jurídico-administrativa da subsidiariedade, à qual ressalta um aspecto primordial da atividade estatal, conquistado a duras penas após anos de arbítrio: o fato de o Poder Público somente ser legitimado a agir mediante uma função pública, definida em lei, obrigatoriamente vinculada a um interesse público concreto, motivado e objetivamente definido. A função aqui tratada reflete a necessidade de a atividade administrativa interventiva ser pautada por um critério de necessidade e de tipicidade ${ }^{302}$ com as garantias a elas inerentes, resultado óbvio da imposição da regra da legalidade da intervenção econômica pública ${ }^{303}$. Nas palavras de Carlos Ari SUNDFELD:

"A atividade pública - cujo exercício é regulado pelo direito público constitui função. Função, para o Direito, é o poder de agir, cujo exercício traduz verdadeiro dever jurídico, e que só se legitima quando dirigido ao atingimento da específica finalidade que gerou sua atribuição ao agente. $O$

${ }^{301}$ Cf. OTERO, Paulo, Vinculação e Liberdade de Conformação Jurídica do Sector Empresarial do Estado, op. cit., página 35.

${ }^{302}$ Cf. OTERO, Paulo, Vinculação e Liberdade de Conformação Jurídica do Sector Empresarial do Estado, op. cit., p. 36.

${ }^{303}$ Não cabe logicamente aqui desenvolver o tema, mas é reconhecível que falar atualmente da importância dos conceitos de Estado de direito e de legalidade é quase um truísmo. Em tempos de absolutismo, o poder soberano do monarca, exercido na condição de representante de Deus na sociedade, significava que sua vontade era a lei suprema, incontrastável e incontestável pelos súditos, o que resultava em evidentes e constantes abusos. Mesmo nas monarquias constitucionais e no Estado burguês, que já contavam com um regime de captura do Estado pelo Direito, o sistema se mostrava ainda insuficiente, uma vez que embora as leis fossem promulgadas por representantes do povo, a alta carga de responsabilidade decisória alocada na Coroa, alheia ao Direito, fazia com que os súditos ainda fossem tratados como meros objetos. Pois somente com o amadurecimento da sociedade e o reconhecimento dos direitos dos indivíduos, principalmente a liberdade e a propriedade, é que se tornou possível conceber um Estado que realiza suas atividades debaixo da ordem jurídica. E é nesse sentido que exsurge a noção clássica de legalidade como a submissão da Administração Pública à lei, de modo que "[m]ediante a submissão da Administração à lei, o poder tornava-se objetivado: obedecer à Administração era obedecer à lei, não à vontade instável da autoridade." (Cf. MEDAUAR, Odete, O Direito Administrativo em Evolução, op. cit., página 144) 
legislador, o administrador, o juiz, desempenham função: os poderes que receberam da ordem jurídica são de exercício obrigatório e devem necessariamente alcançar a finalidade por ela mirada" ${ }^{304}$.

Assim, enquanto aos particulares é garantido "o livre exercício de qualquer atividade econômica, independentemente de autorização de órgãos públicos, salvo nos casos previstos em lei" (CF, art. 170, parágrafo único), ao Poder Público incide a obrigatoriedade de somente intervir mediante o exercício legítimo de uma função pública, definida em uma regra de competência. Em outras palavras, as atividades econômicas em geral são livres a todos os cidadãos, mas ao Estado somente é permitido exercê-las ou mesmo nelas intervir de alguma maneira quando houver fundado interesse coletivo traduzido em uma função pública definida em lei.

Nesse sentido, parece bastante óbvio que a liberdade privada de acesso a uma atividade econômica (ainda que amplamente restringível para a garantia de outros valores e direitos fundamentais), conforme conferido pela Constituição, não pode ser confundida ou igualada com o regime de competência, de exercício de função pública, que é o sistema reservado à intervenção econômica pública ${ }^{305}$. Segundo as já clássicas lições de Celso Antônio BANDEIRA DE MELLO, “[o]nde há função, pelo contrário, não há autonomia da vontade, nem a liberdade em que se expressa, nem a autodeterminação da finalidade a ser buscada, nem a procura de interesses próprios, pessoais. Há adscrição a uma finalidade previamente estabelecida e, no caso de função pública, há submissão da vontade ao escopo pré-traçado na Constituição ou na lei e há o dever de bem curar um interesse alheio que, no caso, é o interesse público; vale dizer, da coletividade como um todo e não da entidade governamental em si mesma considerada",306.

\footnotetext{
${ }^{304}$ Fundamentos de Direito Público, 4 a ed., São Paulo: Malheiros Editores, 2006, página 163.

${ }^{305}$ Conforme anota António L. SOUSA FRANCO, "[o] princípio da liberdade - que decorre do direito de liberdade económica nos sistemas em que existe - definirá que a regra é o livre exercício das actividades produtivas pela generalidade dos sujeitos econômicos, tomando como sujeitos típicos os agentes privados (...) Ao invés, no sistema da competência o acesso à atividade económica depende sempre da definição de áreas legais em que se exerce a actividade económica, para cada sector e cada tipo de agentes económicos, quer a lei o defina em abstracto (competência legal) quer faça depender o acesso de juízos discricionários de agentes socais dotados de autoridade (competência com discricionariedade administrativa, competência com juízo sobre o acesso das autoridades, etc.)." (Nota Sobre o Princípio da Liberdade Económica, in Boletim do Ministério da Justiça, $\mathrm{n}^{\circ}$ 355, Portugal: Ministério da Justiça, 1986, páginas 18-19)

${ }^{306}$ Curso de Direito Administrativo, op. cit., página 101. No mesmo sentido, anota Carlos Ari SUNDFELD que "[a]o princípio da função, próprio do direito público, opõe-se o da autonomia da
} 
Daí porque entender que a subsidiariedade aplicada à ordem econômica é a expressão mesma de uma disparidade de regimes jurídicos, o regime de liberdade dos cidadãos e o regime de competência do Estado. O fato de a atividade estatal em geral somente se justificar em face de um interesse público, definido em norma legal que crie a competência administrativa, obriga reconhecer que a intervenção estatal somente se justifica se respeitadora da regra da subsidiariedade. A ausência de necessidade (pela suficiência dos agentes privados em gerir o setor, ou pela inexistência de valores a serem resguardados) definida como interesse público desautoriza a intervenção estatal. De outro modo, uma intervenção estatal nestes termos mostrar-se-ia ociosa, desnecessária e, portanto, ilegítima.

No caso da regulação administrativa da economia, objeto central do presente trabalho, o tema acaba se colocando de forma ainda mais evidente. É que, conforme se disse acima, a atividade tem como elo de legitimidade a lei que institui a competência do órgão administrativo incumbido da regulação. Em outras palavras, embora se saiba que a atividade regulatória não se subsume à reprodução da lei (ao contrário, a inova), é certo que a regulação administrativa tem origem e se limita no quanto estabelecido, autorizado ou admitido pela lei. Logo, parece bastante evidente que esse caráter de função pública no exercício de competência administrativa atribuída por lei se mostra ainda mais notório em termos de regulação econômica administrativa. Daí a se reconhecer que a regulação econômica administrativa desprovida de fundamento de interesse público (aqui sem qualquer menção às disputas ideológicas das Escolas de Interesse Público e Neoclássica da regulação ${ }^{307}$ ), consubstanciado justamente na necessidade de implementação de pautas públicas não alcançáveis diretamente pelos atores privados, se mostraria ilegal.

De fato, desde uma perspectiva de direito administrativo e de legitimação da atividade estatal, não haveria muito sentido que um regulador qualquer, embora admitindo que os atores privados pudessem garantir determinada finalidade de interesse público no mercado, estabelecesse um comando regulatório por motivos de interesse público. Ora, qual interesse público? Se tais pautas são atingíveis diretamente

vontade, vigente no direito privado. Enquanto naquele os atos se vinculam a certo fim, que deve ser necessariamente atingido, neste, os atos são produzidos nos termos da vontade livre dos particulares." (Fundamentos de Direito Público, op. cit., página 166)

${ }^{307}$ Cf. entre inúmeros outros SALOMÃO FILHO, Calixto, Regulação da Atividade Econômica, op. cit., páginas 22-32. 
pelos particulares, então qual o sentido de uma regulação autorreferencial? E custos administrativos e econômicos das esferas públicas e privadas, onde se encaixam nessa equação?

Portanto, quer nos parecer que o critério de condição-fundamento da subsidiariedade como elemento norteador da intervenção administrativa no domínio econômico é inegável. Como anota Paulo OTERO, "[d]ominada a sociedade civil por um princípio geral de liberdade, (...) a intervenção pública deverá sempre reger-se por uma regra de excepção, enquanto afirmação, também ela implícita, do princípio da subsidiariedade" ${ }^{308}$.

\section{III.5.4. Subsidiariedade, regulação administrativa da economia e concretização}

Conforme se viu, e igualmente nos termos que já tínhamos anunciado no item II.2.1 do presente trabalho, os fundamentos da afirmação da subsidiariedade da intervenção estatal têm substrato constitucional, o que a faz emergir como critério obrigatório ao Estado de modo geral. Com isso, é possível dizer que qualquer modalidade de intervenção estatal na ordem econômica se subsume ao critério da subsidiariedade tal qual aqui exposto. E de fato essa afirmação é verdadeira ${ }^{309}$.

Dizer, entretanto, que o Estado deve respeitar a subsidiariedade, embora certamente importante, pode ser ainda insuficiente. Nesse sentido, tão ou mais relevante parece ser demonstrar como a subsidiariedade pode ser implementada pelo Poder Público nas atividades interventivas a seu cargo. Um itinerário com esse nível de abrangência certamente transbordaria os limites do presente estudo. Daí o sentido de se focar apenas na subsidiariedade como limite à atividade regulatória exercida pela Administração Pública, aqui chamada de regulação administrativa da economia. De outra sorte, teríamos que nos debruçar inclusive sobre os mecanismos admitidos em direito para o controle da atividade legislativa que incide em restrições no mercado, isto é, do controle de constitucionalidade de leis que regulam atividades econômicas em

\footnotetext{
${ }^{308}$ Vinculação e Liberdade de Conformação Jurídica do Sector Empresarial do Estado, op. cit., página 36.

${ }^{309} \mathrm{Cf}$. MARQUES NETO, Floriano de Azevedo, O Fomento como Instrumento de Intervenção Estatal na Ordem Econômica, op. cit., página 61.
} 
alguma medida. Embora certamente importante, uma abordagem dessa natureza iria muito além dos limites aqui propostos.

Portanto, cumpre aqui reiterar uma vez mais que a atividade regulatória que nos interessa, e a qual irá incidir o vetor da subsidiariedade aqui estudado, é a desempenhada pela Administração Pública. Especificamente sobre esta parcela da intervenção estatal no domínio econômico é que buscaremos adiante tratar dos mecanismos de concretização que podem legitimar tudo o que se afirmou até então. 


\section{CAPÍTULO IV. A SUBSIDIARIEDADE CONCRETAMENTE IMPLEMENTADA: A ANÁLISE DE IMPACTO REGULATÓRIO}

\section{IV.1. Subsidiariedade em dois momentos: na verificação do objetivo público a ser implantado e na sua definição concreta}

Vincada a subsidiariedade como efetivo vetor de restrição da intervenção regulatória administrativa da economia, interessa-nos perquirir como é possível concretizá-la de alguma forma. Sim, pois há efetivamente algo de abstrato no discurso sobre o respeito à suficiência dos atores privados em implementar pautas públicas. Em verdade, afirmar simplesmente que o vetor de subsidiariedade deve ser respeitado pela Administração Pública, embora acertado, por si só, não representa algo muito concreto. Daí a necessidade de perquirir como e em que medida pode a Administração Pública garantir que o exercício de sua competência regulatória não implicará em restrição indevida à livre iniciativa econômica atores privados.

Tendo isso em mente, parece certo que a subsidiariedade, conforme acima sustentada, apresenta-se como um limite objetivo à intervenção regulatória administrativa em dois momentos distintos.

Em primeiro lugar, o vetor de subsidiariedade incide na verificação de algum objetivo de interesse público a ser efetivamente alcançado por determinado setor econômico ou até mesmo no mercado como um todo. A presunção inicial nesses casos (e apenas inicial) é que os atores privados têm se mostrado em alguma medida incapazes de alcançar por conta própria os valores efetivamente almejados, o que daria ensejo à tutela estatal mediante a intervenção regulatória administrativa. Trata-se, pois, de papel típico das políticas públicas setoriais estabelecidas em âmbito governamental com a finalidade específica de identificar um objetivo de interesse público consentâneo com as finalidades constitucionais e legais a ser implementado em determinado setor ${ }^{310}$. De certa forma, o exercício aqui vislumbrado parece ser o de identificar uma finalidade econômico-social almejável, adequada aos desígnios legais e governamentais sobre um

\footnotetext{
${ }^{310}$ Cf. MARQUES NETO, Floriano de Azevedo, Agências Reguladoras Independentes, op. cit., páginas 86-87.
} 
setor (inseridos, pois, em políticas de estado, de governo e públicas ${ }^{311}$ ), e que por algum motivo não esteja sendo concretizada em determinado momento.

$\mathrm{O}$ vetor de subsidiariedade incide nesta etapa do planejamento regulatório, como se disse acima, sob um critério de presunção. Isto é, presume-se que determinado objetivo econômico ou social não esteja sendo devidamente alcançado por conta da incapacidade dos atores privados, daí a ensejar a formulação de programas de ação que resultem em atos regulatórios concretos. Assim, mesmo em sede de planejamento da atividade regulatória não se pode ignorar o dever de se demonstrar que (i) a regulação vislumbrada conduzirá a concretização do objetivo almejado e (ii) que o mercado teoricamente não se mostra apto a alcançar tais resultados, justificando, assim, a eventual restrição privada. Em verdade, o que se quer dizer é o vetor da subsidiariedade na intervenção regulatória não deve deixar de ser uma preocupação da Administração Pública nem mesmo na fase de programação da atividade.

Por outro lado, mais importante mesmo é o segundo momento de aplicabilidade do critério da subsidiariedade, o qual reside na implementação da regulação propriamente dita. Nesta etapa, deverá a Administração abrigar uma análise com a finalidade de perquirir se e de que maneira a medida intentada pode ser bem sucedida sem restringir ilegitimamente a liberdade dos cidadãos (o que, viu-se acima, perpassa a mera generosidade estatal). Via de consequência, cumpre ao Poder Público se certificar que a iniciativa privada não consegue atingir a totalidade ou mesmo parte dos fins objetivados com a medida regulatória. Há aqui, portanto, algo que nos remete à ideia de necessidade da intervenção administrativa (segundo teste da proporcionalidade, tal qual exposto no item III.5.2.c) e da existência de um instrumento próprio para essa análise das capacidades do mercado. A primeira ideia foi apresentada linhas acima e não

\footnotetext{
311 Adotamos aqui os conceitos de políticas de estado, de governo e políticas públicas anotados por Floriano de Azevedo Cf. MARQUES NETO, Agências Reguladoras Independentes, op. cit., páginas 85-87. Segundo esse autor, "[p]olíticas de estado são aquelas definidas, por lei, no processo complexo que envolve o Legislativo e o Executivo. Nelas vêm consignadas as premissas e objetivos que o Estado brasileiro, num dado momento histórico, quer ver consagradas para um determinado setor da economia ou da sociedade." Por outro lado, "[p]olíticas de governo são os objetivos concretos que um determinado governante eleito pretende ver impostos a um dado setor da vida econômica ou social. Dizem respeito à orientação política e governamental que se pretende imprimir a um setor. Hão de estar adstritas, obviamente, às políticas de estado". Não obstante, "políticas públicas são metas, programas, princípios e objetivos da ação governamental definidas a partir dos processos decisórios politicamente mediados com vistas a orientar, articular e coordenar a atuação de agentes públicos e privados e a alocação de recursos públicos e privados para atingir interesses públicos considerados relevantes num dado momento histórico".
} 
enseja maiores dúvidas; a segunda, liga-se à questão da análise de impacto regulatório, a qual deve ser aprofundada adiante.

\section{IV.2. A Análise de Impacto Regulatório - AIR}

\section{IV.2.a. As preocupações com a melhora da qualidade da regulação e as experiências internacionais}

No Brasil, o processo de rulemaking regulatório está muito ligado à ideia de legitimação pela procedimentalização e pela participação dos interessados. Inúmeros foram os trabalhos acadêmicos voltados à questão do alegado déficit democrático de órgãos independentes (destacados da estrutura administrativa hierarquizada) dotados de competência normativa ${ }^{312}$. A solução para este impasse foi constatar que, embora não resultante do processo democrático direto (sufrágio), tais entidades teriam suas decisões legitimadas por um processo administrativo substantivo que envolveria a participação de toda a sociedade (particulares direta, indireta e eventualmente afetados ${ }^{313}$ ), com ampla publicidade e transparência decisória ${ }^{314}$.

Este talvez seja o principal motivo pelo qual a qualidade da regulação produzida não chegou a ser uma preocupação muito difundida entre nós.

\footnotetext{
${ }^{312}$ Cf., entre outros, JUSTEN FILHO, Marçal, Agências Reguladoras e Democracia: Existe um Déficit Democrático na "Regulação Independente"?, in ARAGÃO, Alexandre Santos de (org.), O Poder Normativo das Agências Reguladoras, Rio de Janeiro: Forense, 2006, páginas 301-332; BINENBOJM, Gustavo (coord.), Agências Reguladoras e Democracia, Rio de Janeiro: Lumen Juris, 2006; MARQUES NETO, Floriano de Azevedo et. al., Há um Déficit Democrático nas Agências Reguladoras?, in Revista de Direito Público da Economia - RDPE, no 5, Belo Horizonte: Fórum, jan/2004, páginas 163-224; FARIA, José Eduardo (org.), Regulação, Direito e Democracia, São Paulo: Editora Fundação Perseu Abramo, 2002.

313 Como escreve Luciano Parejo ALFONSO, a participação no processo administrativo envolve os interessados necessários, que são aqueles cuja ausência torna impossível a tramitação processual (os que promovem o processo como titulares dos direitos ou interesses legítimos e os que terão seus direitos afetados pela decisão), e os interessados possíveis ou eventuais, que configuram a classe de administrados em que há possibilidade de afetação de seus interesses legítimos, individuais ou coletivos, e que por conta disso, se apresentam ao processo antes da decisão administrativa final (Derecho Administrativo, Barcelona: Ariel, 2003, páginas 723-724). Tratando do direito brasileiro, Odete MEDAUAR interpreta a locução do inciso LV do artigo $5^{\circ}$ da Constituição Federal de modo a extrair que o termo 'litigante' deve ser lido com a maior amplitude possível, de modo que este surja diante de qualquer controvérsia, em razão de um simples conflito de interesses, basicamente quando houver discordância (A Processualidade no Direito Administrativo, $2^{a}$ ed., São Paulo: Revista dos Tribunais, 2008, página 81).

${ }^{314} \mathrm{O}$ que, a bem da verdade, repete em muito a regra de produção normativa do $\S 553$ do Administrative Procedural Act norte americano.
} 
Entretanto, há tempos os países mais acostumados com o mecanismo da regulação econômica têm se empenhado com o tema da melhora e da otimização das normas regulatórias produzidas. Conforme relata Cass R. SUNSTEIN, o período do pós New Deal nos EUA, notadamente durante a década de 1980, trouxe à tona preocupações com o excesso e a qualidade da regulação produzida pelas agencias americanas, já muitas delas falharam em atingir os objetivos confiados, tendo ainda frequentemente piorado o quadro original. Baseado nessa concepção, afirma o autor que "não há sugestão de que os mercados são ideais; mas frequentemente funcionam melhor que programas regulatórios designados como soluções", daí que "a questão é se os benefícios justificam os custos $^{\prime 315}$. Em verdade, na esteira do que apontam Lucia Helena SALgado e Eduardo Bizzo de Pinho BORGES, desde os ensinamentos utilitaristas de Jeremy Bentham já se propugnava que as ações estatais interventivas deviam calibrar custos e benefícios sociais em qualquer hipótese $e^{316}$, o que configura certamente uma preocupação qualitativa sobre a atividade do Poder Público.

A busca pela melhoria da qualidade regulatória propugna justamente isso: a necessidade de examinar de forma mais próxima a capacidade da regulação de atingir suas finalidades. Afinal, se há um caminho melhor e mais apto a atingir o mesmo objetivo, de forma mais eficiente, com menores custos financeiros e sociais, através de um sistema interventivo menos intrusivo, então por que não fazê-lo? Assim, e na esteira do pensamento de Stephen WEATHERILL, a melhora regulatória envolve a ênfase na transparência e na necessidade de uma avaliação completa do impacto da medida, a fim de garantir que a decisão sobre a melhor alternativa esteja lastreada em um contexto amplo e adequado. Daí sua conclusão de que "a transparência e a profundidade na consulta são características prováveis de uma agenda de 'melhor regulamentação', da

\footnotetext{
315 The Cost-Benefit State, University of Chicago Law School, John M. Olin Law \& Economics, Working Paper $\mathrm{n}^{\circ}$ 39, mai/1996, página 9. Disponível em: www.law.uchicago.edu/files/files 139.sunstein.pdf.

${ }^{316}$ Análise de Impacto Regulatório: Uma Abordagem Exploratória, texto para discussão $n^{\circ} 1463$, Brasília: IPEA, 2010. Disponível em: http://www.regulacao.gov.br/publicacoes/artigos/analise-deimpacto-regulatorio-uma-abordagem-exploratoria. Conforme apontava BENTHAM, "[u]ma medida governamental (que é apenas um tipo particular de ação, exercido por uma particular pessoa ou pessoas) pode ser endereçada para ser conformada ou ditada pelo princípio da utilidade, em que a tendência para aumentar a felicidade da comunidade é maior do que sua capacidade para diminuí-la" (An Introduction to Principles of Morals and Legislation, vol. I, Londres: W. Pickering, 1823, página 5 - tradução livre).
} 
mesma forma como também são o cálculo ex post e a análise do desempenho real de um instrumento regulatório" ${ }^{317}$.

Nos EUA, distanciando-se do que apontava Cass Sunstein linhas acima, desde os anos 1970s já era possível notar uma evidente preocupação com os custos e a inflação regulatória e legislativa existente, traduzida na edição da Executive Order 11821 - Inflation Impact Statements (de 1974) e da Executive Order 12044 Improving Government Regulations (de 1978). A primeira order estabelecia o dever de qualquer proposta de lei ou regulação vir acompanhada com declaração de que houve a devida análise de impacto inflacionário da proposta nas normas já existentes; já a segunda propugnava o dever de que todas as agências reformulassem seu mecanismo de produção normativa, determinando ainda o seguinte:

"A regulação deve ser tão simples e clara quanto possível. Elas devem atingir as metas legislativas de forma eficaz e eficiente. Elas não devem impor encargos desnecessários sobre a economia, sobre os indivíduos, em organizações públicas ou privadas, ou em governos estaduais e locais."

Já em 1981, sob o governo de Ronald Reagan e muito influenciado pelo viés ambientalista da regulação prevalecente nos anos 1970s, foi editada a Executive Order 12291, que criou uma série de princípios substantivos obrigatórios para todas as agências na edição de normas regulatórias ${ }^{318}$, como a ponderação de custos e benefícios sociais, inclusive e especialmente o dever de realizar uma análise de impacto regulatório contendo basicamente o seguinte: (i) uma descrição dos potenciais benefícios da norma, inclusive daqueles que não possam ser quantificados monetariamente; (ii) uma descrição dos potenciais custos, incluindo os adversos que não possam ser quantificados em termos monetários e quem os suportarão; (iii) a determinação dos potenciais benefícios líquidos, incluindo uma avaliação dos efeitos que não possam ser quantificados monetariamente; e $(\boldsymbol{i v})$ uma descrição das potenciais abordagens alternativas que poderiam substancialmente alcançar os mesmos objetivos regulatórios a um menor custo, conjuntamente com uma analise dos seus eventuais

\footnotetext{
${ }^{317}$ The Challenge of Better Regulation, in WEATHERILL, Stephen (ed.), Better Regulation, Oxford: Hart Publishing, 2007, páginas 7-8.

${ }^{318}$ SUNSTEIN, Cass, The Cost-Benefit State: The Future of the Regulatory State, Chicago: American Bar Association, 2002, páginas 10-11.
} 
custos e benefícios, incluindo ainda a explicação das razões legais que não impedem a sua edição ${ }^{319}$.

A mesma racionalidade foi mantida com a Executive Order 12498 de 1985 e com a Executive Order 12866 de 1993 (já sob o governo de Bill Clinton), a qual tinha, esta última, a finalidade alegada de 'reinventar o governo ${ }^{\prime 320}$. Em 1995 foi editado o Risk Assessment and Cost-Benefit Act (HR 1022), que passou a tratar do tema como análise de custo/benefício, cuja obrigatoriedade se dirigia unicamente às regulações consideradas "majors", ou seja, qualquer norma cujo cumprimento anual superasse US\$ 25 milhões $^{321}$. Em 2003, já sob a administração de George Bush, foi criada a Circular $A-4$, que regulamentava o exercício de revisão da regulação administrativa editada pelas agências, a cargo do Office of Information and Regulatory Affairs - OIRA, departamento integrante do Office of Management and Budget - OMB, conforme estabelecia a Executive Order $12866^{322}$. Mais recentemente, em janeiro de 2011, o presidente Barack Obama editou a Executive Order 13563, que expressamente reafirmou as normas anteriores mas acresceu o dever de as agências incluirem no debate valorativo a equidade, a dignidade humana, a justiça e os impactos distributivos.

Embora idealizada nos EUA, essa espécie de processo racional de produção de normas regulatórias foi também instituído na Europa. No Reino Unido,

\footnotetext{
${ }^{319}$ Este o teor da letra 'd' da seção 3 da Executive Order 12291: "(d) Para permitir que cada regra principal proposta seja analisada à luz dos requerimentos estabelecidos na Seção 2 desta Order, cada Análise de Impacto regulatório preliminar e final deve conter a seguinte informação: (1) Uma descrição dos potenciais benefícios da regra, incluindo quaisquer efeitos benéficos que não podem ser quantificados em termos monetários, bem como a identificação de seus potenciais beneficiários; (2) Uma descrição dos potenciais custos da norma, incluindo aqueles efeitos adversos que não podem ser quantificados em termos monetários, bem como a identificação de quem possivelmente suportará seus custos; (3) Uma determinação dos potenciais benefícios líquidos da regra, incluindo uma avaliação dos efeitos que não podem ser monetariamente quantificados; (4) Uma descrição das abordagens alternativas que poderiam substancialmente atingir os mesmos objetivos regulatórios a um custo mais baixo, acompanhada de uma análise de seus custos e benefícios e de uma breve explicação das razões legais pelas quais tais alternativas, se propostas, não poderiam ser adotadas; e (5) A menos que não coberta pela descrição contida no parágrafo (4) desta subseção, uma explicação sobre as razões jurídicas pelas quais a regra não pode ser baseada nos requisitos estabelecidos na Seção 2 desta Order" (tradução livre).

${ }^{320}$ Cf. HAHN, Robert W., State and Federal Regulatory Reform: a comparative analysis, in ADLER, Matthew D. e POSNER, Eric A. (ed.), Cost-Benefit Analysis: Legal, Economic and Philosophical Perspectives, Chicago: The University of Chicago Press, 2000, página 51.

${ }^{321}$ Cf. FUGUITT, Diana e WILCOX, Shanton J., Cost-Benefit Analysis for Public Sector Decision Makers, Westport: Quorum Books, 1999, página 11.

${ }^{322}$ Cf. PESSÔA VALENTE, Patrícia Rodrigues, A análise de impacto como mecanismo de controle do tabaco, in Revista de Direito público da Economia - RDPE, ano 8, n 32, Belo Horizonte: Fórum, out/dez 2010, página 118.
} 
informa a doutrina que quaisquer regulações que ultrapassem os GBP 5 milhões de custos ao Poder Público demandam a realização de análise de impacto regulatório, a qual é coordenada pelo Better Regulation Executive e controlada pelo National Audit Office - NAO $O^{323}$. No restante da União Europeia, cujos esforços mais exponenciais para a melhoria da qualidade regulatória se iniciam nos anos $1980 \mathrm{~s}^{324}$, há atualmente necessidade de se observar os regramentos das Regulatory Policy Guidelines de 1996 (fundadas em diversos dispositivos do Tratado da CCE), que exigem a realização de uma análise de impacto regulatório contendo avaliação orçamentária, impacto ambiental e impacto mercadológico ${ }^{325}$.

\section{IV.2.b. O que é a Análise de Impacto Regulatório - AIR?}

Muito desse debate sobre a qualidade e o custo/benefício da regulação acaba por evidenciar uma evolução natural do tema, resultado do próprio conteúdo reflexivo da atividade regulatória, e que acaba desaguando em questionamentos sobre os custos sociais, jurídicos e econômicos do efetivo exercício da atividade. A questão que se coloca nesse processo é: em que hipóteses se mostra mais eficiente para todos os envolvidos (administrados, atores privados, Administração Pública, portadores de interesses legítimos, etc.) regular, não regular ou, ainda, de que forma regular?

Isto porque, sabe-se que a regulação não produz benefícios ao interesse público per se: se insuficiente ou equivocada, não produz os efeitos imaginados e se torna um gasto público inútil, impertinente, ocioso e ilegítimo; se inexistente quando necessária, implica em omissão administrativa, ensejando toda sorte de responsabilização pública e a não consagração de um valor tido como de interesse público. Mais do que isso, se excessiva ou incidente em espaços desnecessários, seja impedindo a inovação ou criando barreiras impertinentes ao comércio, à concorrência,

\footnotetext{
${ }^{323}$ Cf. PESSÔA VALENTE, Patrícia Rodrigues, A análise de impacto como mecanismo de controle do tabaco, op. cit., páginas 118-119.

${ }^{324}$ Cf. PELKMANS, Jacques, LABORY, Sandrine e MAJONE Giandomenico, Better EU Regulatory Quality: Assessing Current Initiatives and New Proposals, in GALLI, Giampaolo e PELKMANS, Jacques (ed.), Regulatory Reform and Competitiveness in Europe: Horizontal Issues, Vol. I, Massachusetts: Edward Elgar Publishing, 2000, páginas 461 e ss.

${ }^{325}$ Cf. The European Policy Center, Regulatory Impact Analysis: Improving the Quality of EU Regulatory Activity, ocasional paper, set/2001, páginas 11-13. Disponível em: http://ec.europa.eu/dgs/secretariat_general/admin burden/docs/enterprise/files/epc paper en.pdf.
} 
ao investimento e à eficiência econômica, a regulação pode se transformar em obstáculo para que sejam atingidos os objetivos mais elementares de bem-estar social e econômico para os quais ela foi desenhada ${ }^{326}$.

Daí a importância de um espaço adequado para analisar as possíveis alternativas regulatórias e quais os impactos potenciais de cada uma delas, o que se costumou chamar de Análise de Impacto Regulatório - AIR. A AIR foi definida pela Organização para a Cooperação e Desenvolvimento Econômico - OCDE como uma ferramenta utilizada para examinar e medir os possíveis benefícios, custos e efeitos de uma nova ou já existente regulação. Em verdade, a AIR busca ser ao mesmo tempo uma ferramenta e um processo decisório instituído para informar a Administração de que forma e em quais espaços se deve incidir a regulação para atingir os objetivos públicos desejados, o que a faz funcionar como um verdadeiro mecanismo de governança regulatória ${ }^{327}$. Configura, assim, uma espécie de checklist analítico voltado para ajudar a tomada de decisão do regulador, uma vez que resulta na exteriorização das possíveis alternativas regulatórias e não regulatórias aptas a alcançar o interesse público desejado $^{328}$. Assim é que esse rol que questões indicativas sugeridas pela OCDE acaba sendo bastante útil para tornar a atividade mais consentânea com as necessidades sociais.

Nesse sentido, para a OCDE, qualquer proposta de regulação relevante deve conter respostas às seguintes indagações:

\section{"1. O problema está corretamente definido?;}

2. A ação governamental é justificada?;

3. A regulação é a melhor forma de atuação estatal?;

4. Há base legal para a regulação?;

5. Qual o nível (ou níveis) apropriado(s) de ação governamental?;

\footnotetext{
${ }^{326}$ Cf. GAETANI, Francisco e ALBUQUERQUE, Kélvia, Análise de Impacto Regulatório e Melhoria Regulatória, in RAMALHO, Pedro Ivo Sebba (org.), Regulação e Agências Reguladoras: Governança e Análise de Impacto Regulatório, Brasília: Anvisa, 2009, página 191.

${ }^{327}$ Cf. Organização para a Cooperação e Desenvolvimento Econômico - OECD, Regulatory Impact Analysis: A Tool For Policy Coherence, 2009, página 12.

${ }^{328}$ Organização para a Cooperação e Desenvolvimento Econômico - OCDE, Building an Institutional Framework for Regulatory Impact Analysis (RIA): Guidance for Policy Makers, version 1.1, Regulatory Policy Division - Directorate for Public Governance and Territorial Development, Paris, 2008, p. 11 e 14.
} 
6. Os benefícios da regulação justificam seus custos?;

7. A distribuição dos efeitos perante a sociedade é transparente?;

8. A regulação é clara, consistente, compreensível e acessível aos usuários?; e

9. Todos os eventuais interessados tiveram oportunidade de apresentar sus pontos de vista?" 329

De todo modo, cumpre ressaltar que mesmo se tratando de um instrumento específico de auxílio à atividade regulatória em geral, a nomenclatura utilizada não é de forma nenhuma unívoca. Segundo Ivan César RIBEIRO, os nomes dados para os sistemas de análise de impacto regulatório variam bastante, podendo-se falar de RIA (que serve para Regulatory Impact Analysis ou para Regulatory Impact Assessment), de RIAS - Regulatory Impact Analysis Statement, ou mesmo de CBA Cost-Benefit Analysis, que pode tanto se confundir com a RIA ou se tratar de uma metodologia especifica para a sua condução ${ }^{330}$. Rafael Carvalho Rezende de OLIVEIRA, por outro lado, chama atenção ainda para a Cost-Effectiveness Analysis CEA, a Risk-Analisys e a Risk-Risk Analysis ${ }^{331}$. Já Lucia Helena SALGADO e Eduardo Bizzo de Pinho BORGES apontam também a possibilidade de utilização dos testes de limiar, que são uma forma mais branda de CBA e já são manuseados pelo sistema antitruste brasileiro. Consistem, pois, na aplicação da proporcionalidade, economicidade e eficiência à qualquer ato com a finalidade de verificar eventual dano ou benefício significativo ao sistema regulado, bem como de evitar dispêndios desnecessários de recursos públicos ${ }^{332}$.

Se a nomenclatura utilizada não é uniforme, seu conteúdo e procedimentalização também se mostram bastante indefinidos. Segundo a OCDE,

\footnotetext{
${ }^{329}$ Este o teor original das indagações sugeridas pela OCDE: "I. Is the problem correctly defined?; 2. Is government action justified?; 3. Is regulation the best form of government action?; 4. Is there a legal basis for regulation?; 5. What is the appropriate level (or levels) of government for this action?; 6. Do the benefits of regulation justify the costs?; 7. Is the distribution of effects across society transparent?; 8. Is the regulation clear, consistent, comprehensible and accessible to users?; e 9. Have all interested parties had the opportunity to present their views?" (cf. Building an Institutional Framework for Regulatory Impact Analysis (RIA), op. cit., p. 12-13 - tradução livre).

${ }^{330}$ Regulatory Impact Analysis and Cost Benefit Analysis: What is different across the sea?, in Revista de Direito Público da Economia - RDPE, nº 32, Belo Horizonte: Fórum, out/dez 2010, páginas 75-76.

${ }^{331}$ Governança e Análise de Impacto Regulatório, in Revista de Direito Público da Economia - RDPE, n 36, Belo Horizonte: Fórum, out/dez 2011, página 191.

${ }^{332}$ Análise de Impacto Regulatório: Uma Abordagem Exploratória, op. cit., páginas 15-16
} 
embora muitos países adotem sistemas de análise de impacto regulatório similares em termos de cobertura, controle de qualidade, análise de custo/benefício e consideração dos efeitos na competitividade e em mercados abertos (como Austrália, Canadá, Dinamarca, Alemanha, Itália, Japão, Coréia, México, Nova Zelândia, Noruega, Polônia, Reino Unido e EUA), há outros que engendram análises mais heterogêneas ${ }^{333}$. Nesse sentido, a Holanda adota um sistema de Business Effects Analysis (focado fundamentalmente nos impactos mercadológicos); a República Checa utiliza um mecanismo de Analysis of Financial Impacts and Impacts on the Economy; a França tem um sistema de General Impact Analysis com endereçamento específico em impactos trabalhistas e fiscais; Áustria e Portugal se valem de um Fiscal Analysis focado nos custos orçamentários diretos para o Poder Público; Finlândia possui um amplo mecanismo de análise que cobre impactos orçamentários, econômicos, organizacionais, ambientais, de saúde, politica regional e de igualdade de gênero; Bélgica utiliza apenas o Risk Assesment em casos de regulação focada em saúde, segurança e meio ambiente; e Irlanda, Espanha e Suécia utilizam uma mera lista dos impactos decorrentes das regulações implementadas ${ }^{334}$.

Justamente por conta disso é que parece despropositado pretender instituir um padrão universal de procedimentalização de AIR. Isto é, a Análise de Impacto Regulatório se trata tão somente de um mecanismo processual que tem por finalidade garantir escolhas regulatórias mais racionais e menos onerosas aos corpos sociais e ao próprio órgão regulador. Seu conteúdo, por isso mesmo, é fluído e dependerá das necessidades e regras internas de cada país ou mesmo entidade estatal incumbida de realizá-lo. De todo modo, sua efetiva implementação não pode mais ser

\footnotetext{
${ }^{333}$ É esta também a conclusão de Ivan César RIBEIRO, para quem "[a] principal fonte de confusão, no entanto, vem do conceito de Análise de Custo-Benefício (ACB). Como notam as guidelines da OCDE, 'a análise custo-benefício (CBA) pode ser considerada tanto em termos gerais como em uma abordagem para guiar a tomada de decisões e como uma metodologia específica para conduzir a RIA'. Claramente, enquanto os EUA e, em alguma medida, o Reino Unido considera a CBA como um processo completo para controlar a qualidade da regulação, a UE e outros membros da OCDE a consideram uma das metodologias específicas para ser usada na RIA. As diferenças de terminologia, entretanto, contam para as diferenças de abordagens que cada país adota, de modo que precisamos de um exame mais cauteloso sobre as determinantes acerca dessas disparidades para compreendê-las corretamente" (Regulatory Impact Analysis and Cost Benefit Analysis: What is different across the sea?, op. cit., página 76 tradução livre).

${ }^{334}$ OCDE, Regulatory Impact Analysis (RIA) Inventory, Public Governance and Territorial Development Directorate, abr/2004, páginas 2-3. Disponível em: http://www.oecd.org/regreform/ regulatorypolicy/35258430.pdf.
} 
vista como um capricho ou um mero favor. Trata-se de um sério mecanismo de legitimidade das escolhas regulatórios, tal como nos alerta Marçal JUSTEN FILHO:

"A ausência de Análise de Impacto Regulatório revela a carência de meditação e ponderação sobre as providências pretendidas. Traduz uma decisão subjetiva, desvinculada de fundamentos técnico-científicos. Em se tratando de decisões de grande relevo, a inexistência de Análise de Impacto Regulatório se constitui em defeito insanável e insuperável. Assim se passa porque a autoridade administrativa não pode impor à sociedade alterações radicais e relevantes sem avaliar minuciosamente os efeitos decorrentes. "335

\section{IV.2.c. A Análise de Impacto Regulatório - AIR e a subsidiariedade da intervenção regulatória administrativa}

Do que se viu acima, parece-nos absolutamente evidente que a AIR é o mecanismo processual mais adequado para a garantia do cumprimento do vetor da subsidiariedade da regulação administrativa. Isso porque, o instrumento cuida justamente de avaliar, previamente à sua implementação, as consequências e eventuais alternativas da medida regulatória. Ou seja, a AIR tem como foco exatamente investigar e cotejar soluções alternativas à regulação vislumbrada, buscando com isso analisar os custos e os impactos de cada uma no sentido de se escolher a que traz a melhor proporção de custo/benefício. Logo, é o instrumento institucional mais adequado para se analisar os impactos da medida intentada em virtude da suficiência/insuficiência dos atores privados em implementar fins de interesse público.

Nesse sentido, cabe ressaltar que a mera abertura do processo regulatório à participação dos interessados (no Brasil, algo ainda tímido, se não em alguma medida distorcido ${ }^{336}$ ) tanto não trouxe um adequado equilíbrio entre intervenção

\footnotetext{
${ }^{335}$ Curso de Direito Administrativo, op. cit., página 646.

${ }^{336}$ Não que o modelo seja lastimável ou impraticável no Brasil, mas que efetivamente precisa de reparos. De acordo com Egon Bockmann MOREIRA, com a análise de dados fornecidos pelas próprias ANEEL e ANATEL sobre a participação popular em audiências públicas, a constatação que se tem é que "quem participa ativamente da elaboração normativa de regulação econômica são as empresas dos respectivos setores, que aportam investimentos nessa atividade a fim de conquistar proveitos. As empresas têm um custo relativo à sua interação e ao convencimento dos reguladores, visando a que as normas a ser emanadas as beneficiem diretamente. É um custo despendido na obtenção da legislação (arcado posteriormente pelos usuários e consumidores)" (Agências reguladoras independentes, déficit democrático e a "elaboração processual de normas", in CUÉLLAR, Leila e MOREIRA, Egon Bockmann, Estudos de Direito Econômico, Belo Horizonte: Fórum, 2004, página 198). No mesmo
} 
pública/autonomia privada quanto não tratou adequadamente do maior problema da qualidade da regulação, que é a insuficiência de informação válida disponível e a distorção na sua utilização ${ }^{337}$.

Desse modo, para se chegar a um equilíbrio entre mais ou menos regulação, ou ainda, qual regulação se utilizar, essencial parece ser a adoção de uma metodologia que compare os custos e benefícios de cada opção ${ }^{338}$. Entretanto, como anotam Lucia Helena SALGADO e Eduardo Bizzo de Pinho BORGES, "é preciso fugir do viés economicista e abranger benefícios que, em boa parte, são incertos $e$ difusos por natureza, e custos não quantificáveis" ${ }^{339}$. De fato, a avaliação das opções regulatórias não envolve apenas dados monetariamente quantificáveis (valor despendido pelo Poder Público X valor poupado pela sociedade), mas sim custos sociais muitas vezes incalculáveis ou de difícil avaliação. E mesmo autores entusiastas da análise de custo-benefício reconhecem a dificuldade de se avaliar grande parte dos efeitos envolvidos na regulação. Robert HAHN e Paul TETLOCK, por exemplo, salientam que:

sentido aponta MATTOS, Paulo Todescan Lessa, Agências Reguladoras e Democracia: participação pública e desenvolvimento, in SALOMÃO FILHO, Calixto (coord.), Regulação e Desenvolvimento, op. cit., páginas 211-228. Tais fatos poderiam desavisadamente levar à conclusão de que o tema da capacidade dos atores provados em implementar pautas públicas (vetor de subsidiariedade) estaria sendo observado, afinal, são justamente eles os grandes contribuintes em termos de consultas públicas sobre implementação de medidas regulatórias. Entretanto, entre a mera participação e o efetivo respeito à essa eventual suficiência há um enorme abismo que envolve a racionalidade de melhora na qualidade da atividade regulatória, o que, para nós, indica que a AIR parece ser o melhor caminho.

${ }^{337}$ Conforme anota Cass SUNSTEIN, ainda que sob uma perspectiva excessivamente pragmática (diríamos quase mesmo behavioral), há ao menos seis problemas informacionais que afetam tanto administrados quanto administradores (government officials), e que levam a uma demanda por uma melhor regulação. São eles: (i) a heurística disponível, o que faz com que as pessoas contabilizem apenas os eventos mais publicizados, distorcendo seu julgamento; (ii) o efeito multiplicador da heurística, tendo em vista a tendência das pessoas de aceitar certa informação por conta da crença de outros; (iii) a tendência das pessoas de focar apenas nos riscos de determinado comportamento, esquecendo-se dos benefícios, o que igualmente distorce a percepção sobre a necessidade/oportunidade da regulação; (iv) a dificuldade natural das pessoas de considerar todo o sistema possivelmente afetado durante a tomada de decisão, causando uma espécie de efeito sistêmico; $(\boldsymbol{v})$ a tendência da maioria das pessoas de associar riscos a emoções, não a julgamentos racionais, causando distorções cognitivas de viés alarmista e emocional; e (vi) a tendência natural da maioria das pessoas de adotar posturas diferentes sobre um mesmo assunto se este for analisado individualmente ou de forma conjunta com outros. (Cognition and Cost-Benefit Analysis, in Cost-Benefit Analysis: Legal, Economic and Philosophical Perspectives, op. cit., páginas 228-237)

${ }^{338}$ Cf. RAGAZZO, Carlos Emmanuel Joppert, Regulação Jurídica, Racionalidade Econômica e Saneamento Básico, Rio de Janeiro: Renovar, 2011, página 205.

${ }^{339}$ Análise de Impacto Regulatório: Uma Abordagem Exploratória, op. cit., página 12. 
"Estimar benefícios pode envolver uma longa cadeia justificação que liga ciência básica com efeitos em saúde com a monetarização desses efeitos. Custos são também difíceis de estimar porque não é fácil aferir como as empresas irão responder e como a tecnologia irá evoluir. Além do mais, pode ser bastante difícil estimar como uma política regulatória irá afetar diferentes segmentos da população. Essas preocupações distributivas, embora importantes, não tiveram um foco primário nas análises de custo/benefício." ${ }^{340}$

Assim, parece-nos que o quanto de qualidade de vida será conseguido, a melhora da saúde da população, quanto será garantido às gerações futuras, são todas questões extremamente relevantes para a edição de normas regulatórias que, a despeito de sua natureza relativamente efêmera ${ }^{341}$, se pretendem eficientes e bem sucedidas no atingimentos dos objetivos que fundamentaram sua edição. Pois o respeito à livre iniciativa e a capacidade dos atores privados de implementar por conta própria valores públicos é outro elemento de difícil quantificação, mas que deve ser impreterivelmente inserido nas análises de impacto da atividade regulatória, seja por conta de determinação constitucional, seja porque a autonomia e criatividade privada não podem ser simplesmente ignoradas.

De todo modo, e independentemente das dificuldades aparentes, fato é que a AIR é o instrumentos mais hábil a proporcionar as devidas discussões a respeito da subsidiariedade da regulação econômica ditada pela Administração Pública. Em verdade, a própria ideia de melhora regulatória e de devida proporção entre custos e

\footnotetext{
${ }^{340}$ Has Economic Analysis Improved Regulatory Decisions?, in AEI-Brookings Joint Center, working paper $n^{\circ}$ 07-08, abr/2007, páginas 5-6. Disponível em: http://ssrn.com/abstract=982233.

${ }^{341}$ Em verdade, a ideia de competência normativa dos órgãos reguladores é o cerne da efemeridade e mutabilidade das normas regulatórias. Isto porque, se é verdade que a regulação tem a função de compatibilizar, mediar e ponderar diversos interesses públicos encontradiços no setor regulado, associado ao caráter técnico e específico de nichos mercadológicos cada vez mais permeados pela evolução tecnológica, e se justamente por conta disso que a lei, como ato normativo formal estatuído pelo Legislativo, seria um mecanismo insuficiente em função de um déficit de dinamicidade do processo legislativo (cf. OTERO, Paulo, Legalidade e Administração Pública, op. cit., páginas 152-162), então uma das características das normas advindas da regulação é sua mutabilidade. Justamente por isso que Egon Bockmann MOREIRA defende que "[e]m setores tão sensíveis a demandas populares e inovações tecnológicas, a garantia da mutação regulatória reforça a segurança jurídica. Seria equivocado pensar em estabilidade como sinônimo de imutabilidade, nos mesmos moldes em que se dava nos séculos XVIII, XIX e XX, tempo em que prevalecia o direito monolítico e a idéia de perenidade de legislação. Os 'monumentos legislativos' - tal qual o Código Napoleônico de 1824 e, mesmo, o Código Civil Brasileiro de 1916 - eram criados para durar da mesma forma, para todo o sempre. (...) Na atualidade, para ser estável e perene, é necessário ser mutável. A regulação normativa não tem o atributo de prever o futuro, nem tampouco de o submeter ao Direito. Por isso que a certeza da mudança é uma premissa da segurança." (Agências Administrativas, Contratos de Serviços Públicos e Mutabilidade Regulatória, in Revista de Direito Público da Economia - RDPE, nº 25, Belo Horizonte: Fórum, jan/mar 2009, p. 113
} 
benefícios econômico-sociais traz ínsita a ideia de respeito à eventual autossuficiência da iniciativa privada.

\section{IV.2.d. A AIR no Brasil: o Decreto no 4.176/02 e o PRO-REG}

Anota Carlos Emmanuel Joppert RAGAZZO, que "[a] fase atual da regulação brasileira (...) possui três ondas; cada qual em um estágio diferente de desenvolvimento, partindo desde a consolidação até a discussão meramente prognóstica de implementação" ${ }^{\prime 342}$. Em sua opinião, a primeira onda seria o processo de desregulação e de privatização, com a instituição de órgãos reguladores independentes setoriais, autônomos e independentes. A segunda onda seria a relativa à discussão acerca da legitimidade decisória de tais órgãos, vale dizer, o tema da legitimação pelo processo e pela participação popular. Já a terceira consistiria na melhora da qualidade regulatória, que segundo sua opinião é a que estaríamos no presente momento ${ }^{343}$.

De nossa parte, acreditamos ser possível vislumbrar não três, mas sim quatro fases bastante definidas na história regulatória brasileira, sendo a primeira caracterizada pelas competências regulatórias desde sempre concedidas a órgãos da Administração Pública. Conforme anotamos acima (item II.1), de fato houve um incremento na discussão, teorização e prática da atividade regulatória com a instituição de órgãos independentes e autônomos a partir dos anos 1990s no Brasil. Entretanto, não podemos ignorar que desde sempre houve regulação administrativa da economia e esta invariavelmente foi considerada uma atividade estatal legítima. Assim, tendo em vista que a discussão mais recente sobre regulação no Brasil focou apenas na legitimidade da produção normativa, é possível concluir que estamos em verdade no quarto estágio regulatório brasileiro, consubstanciado justamente pela busca de um ganho de qualidade da regulação produzida.

Nesse sentido, embora ainda um pouco tímida, a Análise de Impacto Regulatório vem sendo efetivamente implementada no Brasil. E a abertura para a análise de prejuízos, benefícios, custos e ganhos de qualquer norma regulatória encontra bases bastante sólidas entre nós.

\footnotetext{
${ }^{342}$ Regulação Jurídica, Racionalidade Econômica e Saneamento Básico, op. cit., página 206.

${ }^{343}$ Regulação Jurídica, Racionalidade Econômica e Saneamento Básico, op. cit., páginas 206-208.
} 
Em primeiro lugar, note-se que o Decreto $n^{\circ} 4.176 / 02$, ainda que dirigido à padronização da elaboração de projetos de atos normativos federais de todas as espécies, é generoso ao demonstrar o quão elementar são os mecanismos que predicam alguma responsabilidade normativa. No anexo I deste documento (intitulado não por outro motivo de "Questões que Devem Ser Analisadas na Elaboração de Atos Normativos no Âmbito do Poder Executivo"), por exemplo, há um rol de questões a serem analisadas e respondidas na elaboração de atos normativos que acabam por constituir elementos típicos de um processo de AIR, notadamente os que se referem à viabilidade de alternativas que alcancem os mesmos fins de modo menos traumático e menos custoso (em sentido amplo) que a medida normativa intentada. Com efeito, para o que aqui importa (ou seja, regulação administrativa da economia), referido dispositivo acaba por representar um ótimo exemplo de reflexão regulatória, vez que exige meditação sobre o seguinte:

\section{"1. Deve ser tomada alguma providência?}

\subsection{Qual o objetivo pretendido?}

\subsection{Quais as razões que determinaram a iniciativa?}

1.3. Neste momento, como se apresenta a situação no plano fático e no plano jurídico?

\subsection{Que falhas ou distorções foram identificadas?}

1.5. Que repercussões têm o problema que se apresenta no âmbito da economia, da ciência, da técnica e da jurisprudência?

1.6. Qual é o conjunto de destinatários alcançados pelo problema, e qual o número de casos a resolver?

1.7. O que poderá acontecer se nada for feito? (Exemplo: o problema tornar-se-á mais grave? Permanecerá estável? Poderá ser superado pela própria dinâmica social, sem a intervenção do Estado? Com que consequências?)

2. Quais as alternativas disponíveis?

2.1. Qual foi o resultado da análise do problema? Onde se situam as causas do problema? Sobre quais causas pode incidir a ação que se pretende executar?

2.2. Quais os instrumentos da ação que parecem adequados para alcançar os objetivos pretendidos, no todo ou em parte? (Exemplo: medidas destinadas à aplicação e execução de dispositivos já existentes; trabalhos junto à opinião pública; amplo entendimento; acordos; investimentos; programas de incentivo; auxílio para que os próprios destinatários alcançados pelo problema envidem esforços que contribuam para sua 
resolução; instauração de processo judicial com vistas à resolução do problema.)

2.3. Quais os instrumentos de ação que parecem adequados, considerandose os seguintes aspectos:

- desgaste e encargos para os cidadãos e a economia;

- eficácia (precisão, grau de probabilidade de consecução do objetivo pretendido);

- custos e despesas para o orçamento público;

- efeitos sobre o ordenamento jurídico e sobre metas já estabelecidas;

- efeitos colaterais e outras consequências;

- entendimento e aceitação por parte dos interessados e dos responsáveis pela execução;

- possibilidade de impugnação no Judiciário. (...)

12. Existe uma relação equilibrada entre custos e benefícios?

12.1. Qual o ônus a ser imposto aos destinatários da norma (calcular ou, ao menos, avaliar a dimensão desses custos)?

12.2. Podem os destinatários da norma, em particular as pequenas e médias empresas, suportar esses custos adicionais?

12.3. As medidas pretendidas impõem despesas adicionais ao orçamento da União, dos Estados e dos Municípios? Quais as possibilidades existentes para enfrentarem esses custos adicionais?

12.4. Procedeu-se à análise da relação custo-benefício? A que conclusão se chegou?

12.5. De que forma serão avaliados a eficácia, o desgaste e os eventuais efeitos colaterais do novo ato normativo após sua entrada em vigor?"

Mas isso não é tudo. O Anexo II do mesmo Decreto $\mathrm{n}^{\circ} 4.176 / 02$ demanda ainda o preenchimento de um formulário sobre a proposta de ato normativo do Executivo federal com respostas do elaborador a respeito de questões que envolvem $(i)$ a síntese do problema ou da situação que reclama providências, (ii) soluções e providências da medida proposta, (iii) alternativas existentes à medida proposta, (iv) custos, (v) impacto sobre o meio ambiente, (vi) alterações propostas e (vii) síntese do parecer do órgão jurídico ${ }^{344}$.

Bem de ver, portanto, que ao menos desde 2002 já há base normativa para a instituição de um verdadeiro processo de Análise de Impacto Regulatório no

\footnotetext{
344 Cf. SALGADO, Lucia Helena e BORGES, Eduardo Bizzo de Pinho, Análise de Impacto
} Regulatório: Uma Abordagem Exploratória, op. cit., páginas 17-18. 
âmbito do Poder Executivo federal. Em verdade, trata o Decreto $n^{\circ} 4.176 / 02$ do marco inicial da AIR no Brasil ${ }^{345}$. Mas não é só.

Em 16.03.2007 foi instituído o Decreto $\mathrm{n}^{\circ}$ 6.062/07, que criou o Programa de Fortalecimento da Capacidade Institucional para Gestão em Regulação PRO-REG. Sua finalidade é justamente "contribuir para a melhoria do sistema regulatório, da coordenação entre as instituições que participam do processo regulatório exercido no âmbito do Governo Federal, dos mecanismos de prestação de contas e de participação e monitoramento por parte da sociedade civil e da qualidade da regulação de mercados" (art. $1^{\circ}$ ). Para tanto, foram formados dois comitês (o Comitê Gestor do PRO-REG - CGP e o Comitê Consultivo do PRO-REG - CCP) envolvendo a Casa Civil, o Ministério da Fazenda, o Ministério do Planejamento, Orçamento e Gestão e todas as dez agências reguladoras federais, com o objetivo de trabalhar cinco vetores elementares: $(\boldsymbol{i})$ fortalecer o sistema regulatório de modo a facilitar o pleno exercício de funções por parte de todos os atores; (ii) fortalecer a capacidade de formulação e análise de políticas públicas em setores regulados; (iii) a melhoria da coordenação e do alinhamento estratégico entre políticas setoriais e processo regulatório; (iv) o fortalecimento da autonomia, transparência e desempenho das agências reguladoras; e (v) o desenvolvimento e aperfeiçoamento de mecanismos para o exercício do controle social e transparência no âmbito do processo regulatório (cf. art. $2^{\circ}$ ).

Nesse sentido, o PRO-REG, com apoio do Banco Interamericano de Desenvolvimento - BID, tem desenvolvido diversos estudos objetivando implantar um sistema adaptado governança regulatória e de AIR no Brasil que leve em conta as dificuldades institucionais brasileiras e as experiências bem sucedidas de outros países.

Questão interessante que se tem colocado diz com os riscos de que o PRO-REG leve a uma significativa perda de autonomia das agências reguladoras já instituídas no Brasil, uma vez que todas as decisões mais relevantes no âmbito do programa serão desenvolvidas pelo Comitê Gestor, que é constituído por representantes da Casa Civil, Ministério da Fazenda e Ministério do Planejamento (art. $6^{\circ}$ ). Ao Comitê Consultivo, composto por representantes das agências referidas na Lei $n^{\circ} 10.871 / 04$

${ }^{345}$ Cf. SAlgADO, Lucia Helena e BORGES, Eduardo Bizzo de Pinho, Análise de Impacto Regulatório: Uma Abordagem Exploratória, op. cit., página 17; OLIVEIRA, Rafael Carvalho Rezende, Governança e Análise de Impacto Regulatório, op. cit., página 200. 
(ANATEL, ANCINE, ANEEL, ANP, ANSS, ANTAQ, ANVISA, ANA e ANAC), dos Ministérios a elas vinculados, do Ministério da Justiça e do CADE compete apenas apresentar e discutir propostas, colaborar tecnicamente e prestar assessorias (art. $9^{\circ}$ ).

Assim, enxerga parte da doutrina a existência de um risco institucional de perda de autonomia das agências, no sentido de a iniciativa governamental estar "permeada com a intenção de esvaziar as competências legalmente instituídas às agências reguladoras independentes e, com isso, retirar destas o (já baixo) grau de autonomia que possuem relativamente ao Poder Executivo central" ${ }^{346}$. De fato, a preocupação é relevante e não pode ser ignorada. Como lembra Alexandre Santos de ARAGÃO, deve-se garantir a coordenação da regulação de forma ampla sem que haja perda de autonomia e independência das instâncias reguladoras setoriais. Em sua opinião, deve-se utilizar novamente um critério de proporcionalidade no sentido de se escolher um meio adequado para realizar o fim buscado, isto é, um mecanismo adequado para concretizar a coordenação:

"Dentre esses meios adequados - e aí vem o elemento necessidade da proporcionalidade -, tem que se escolher o meio menos restritivo à autonomia da agência. Do ponto de vista da adequação, o objetivo a ser visado é a necessidade de coordenação, não a substituição da instância regulatória; e mesmo sendo só para a coordenação, o instrumento a ser adotado tem de ser a forma menos restritiva à independência." ${ }^{347}$

Portanto, um itinerário coerente e apto a coibir abusos parece ser o de controlar a efetivação dos regramentos contidos no PRO-REG pelo critério de proporcionalidade. Caso haja a extrapolação das competências do Comitê Gestor do PRO-REG no sentido de constranger e limitar a autonomia das agências, seria possível vislumbrar um questionamento inclusive judicial. Afinal, competências outorgadas por meio de lei (autonomia e independência das agências) não podem ser neutralizadas por decreto (PRO-REG).

\footnotetext{
${ }^{346}$ Cf. NESTER, Alexandre Wagner, Regulação e Planejamento: A Criação do PRO-REG, in MOREIRA, Egon Bockmann e MATTOS, Paulo Todescan Lessa (coords.), Direito Concorrencial e Regulação Econômica, Belo Horizonte: Fórum, 2010, páginas 477-480.

${ }^{347}$ Análise de Impacto Regulatório - AIR, in Revista de Direito Público da Economia - RDPE, n ${ }^{\circ} 32$, Belo Horizonte: Fórum, out/dez 2010, página 12.
} 
De todo modo, é fácil perceber que a instituição e a prática de se realizar Análises de Impacto Regulatório no Brasil não pode ser encarada como algo distante. Ainda que um pouco tímidas na prática, não há dúvidas que há um fundamento normativo robusto (Decreto $\mathrm{n}^{\mathrm{o}} 4.176 / 02$ ) e uma agenda substantiva de fortalecimento do processo regulatório brasileiro (PRO-REG) ${ }^{348}$.

\section{IV.3. Pautas para a procedimentalização do vetor da subsidiariedade na AIR}

Seria até mesmo leviano suscitar algum tipo de regra geral de Análise de Impacto Regulatório que se pretenda séria. Não é e nem poderia ser esse nosso intuito, afinal, conforme dito acima, a AIR é um processo que tem por finalidade garantir maior racionalidade econômico-social à regulação estatal; sendo assim, os meios aptos para atingir estas metas variarão logicamente de acordo com a legislação e as especificidades institucionais de cada país e de cada órgão com competência regulatória. Não obstante isso, em termos de regulação administrativa incidente no Brasil, e em virtude do quanto disciplinado pelos Decretos $n^{\text {os }} 4.176 / 02$ e 6.062/07, alguns critérios podem ser levantados como importantes fontes analíticas para a implementação de uma regulação que efetivamente respeite e leve em consideração a regra da subsidiariedade da intervenção estatal.

As pautas que se seguem, portanto, têm caráter eminentemente propositivo e se encontram divididas em quatro etapas subsequentes, ainda que grande parte das sugestões configure elemento típico de uma AIR e em alguma medida já previstas em norma existente (ao menos em âmbito federal), bastando focar seu norte para o vetor da subsidiariedade. Assim, reitere-se, cuida-se aqui de apresentar propostas lastreadas em um conceito de padronização mínima, de modo a não fragilizar a capacidade de auto-organização de cada órgão dotado de competência regulatória. Deste modo, o que adiante se propõe busca apenas garantir um processo de AIR assegurador do vetor da subsidiariedade na regulação administrativa da economia.

\footnotetext{
348 Inserto neste contexto se encontra certamente o Programa de Melhoria do Processo de Regulamentação da Anvisa, instituído pela Portaria $n^{\circ} 422 / 08$, e que busca aprimorar o sistema regulatório da Agência e garantir maior qualidade e efetividade da regulação sanitária. E com base no Manual de Boas Práticas Regulatórias elaborado no âmbito do Programa, a Análise de Impacto Regulatória consta como pauta fundamental. $\mathrm{O}$ Manual está disponível em: http://portal.anvisa.gov.br/wps/wcm/connect/7ee9b68047457738852ad53fbc4c6735/GuiaBPReg.pdf?MO $\underline{D=A J P E R E S}$.
} 


\section{IV.3.a. A importância da identificação exata da situação de fato indesejável e do norte a ser implementado}

Em se tratando de exercício que tem como finalidade justamente perquirir e garantir o respeito à eventual suficiência dos atores privados em implementar determinada pauta pública que poderá ser objeto de norma regulatória (não por complacência, insista-se, mas como requisito de legitimidade da atividade estatal interventiva como um todo), essencial definir primeiramente quais exatamente são esses interesses públicos a serem resguardados. Via de regra, identificar os objetivos a serem perseguidos implica em constatar uma situação indesejável que se busca corrigir.

Nesse sentido, conforme dito acima, os objetivos de interesse público a fundamentar a atividade regulatória podem ser todos aqueles atrelados aos princípios inscritos no artigo 170 da Constituição Federal. Pois o exercício a ser aqui perpetrado se liga diretamente com as questões a serem respondidas pelos reguladores nos termos do item 1 do Anexo I do Decreto $\mathrm{n}^{\circ}$ 4.176/02, vale dizer: se deve ser tomada alguma providência?; qual o objetivo pretendido?; quais as razões que determinaram a iniciativa regulatória?; qual a situação atual da questão a ser solucionada?; quais as falhas verificadas?; quais suas repercussões em termo econômicos, científicos, técnicos e jurídicos?; e quais destinatários são alcançados pelo problema?

Ainda que em alguma medida repetitivas, respondendo-se adequadamente a estas questões, consegue-se minimizar significativamente os riscos de que uma norma regulatória seja implementada sem que haja um mapeamento adequado e exaustivo da situação identificada como indesejável, bem como dos objetivos de interesse público concretos a serem buscados. Para além disso, definir exatamente os problemas identificados e as pautas buscadas serve também como mecanismo de controle da atividade, na medida em que garante que eventuais falhas ou exageros sejam sindicados futuramente.

Aqui, portanto, não se está certamente diante de inovação alguma. Para os reguladores em âmbito federal, basta seguir a legislação já existente e exigível. Para os reguladores de outros entes da Federação, a sugestão seria se basear a AIR justamente na legislação federal. De todo modo, com ou sem questionário, o importante 
parece ser identificar a situação tida como indesejável e apontar qual o norte a ser buscado pelo regulador.

\section{IV.3.b. A identificação das respostas possíveis.}

O segundo estágio nesse processo seria justamente identificar quais as possíveis soluções aptas a solucionar os problemas verificados em determinado setor do mercado. É dizer, após identificar os problemas existentes e as metas a serem alcançadas, parece em alguma medida fundamental elencar as possíveis alternativas que se mostrem capazes de corrigir as distorções avaliadas no primeiro estágio.

Note-se que a finalidade neste passo não é cotejar quais as melhores alternativas disponíveis, mas tão somente identificar as soluções regulatórias teoricamente aptas a solucionar os impasses verificados, sem qualquer juízo de valor. Isso porque não se pode excluir nesta fase nenhuma alternativa supostamente viável, sob pena de admitir elementos cognitivos com caráter subjetivo antes do tempo e com capacidade de mascarar as decisões finais a cargo da Administração Pública. E quando se fala aqui em alternativas viáveis, parte-se do pressuposto da existência de soluções que não se mostram nem mesmo equivalentes entre si, ou seja, que não representam soluções regulatórias igualmente injuntivas e mandatórias. Nesse sentido, é plenamente possível que as alternativas vislumbradas contenham elementos de soft law, ou seja, de soluções administrativas baseadas em consenso e em baixa vinculatividade aos atores privados $^{349}$. O importante é que sejam alternativas stricto senso, isto é, teoricamente capazes de solucionar os problemas verificados na primeira etapa.

De todo modo, é interessante notar que o tema aqui proposto também já consta do Anexo I do Decreto n ${ }^{\circ}$ 4.176/02, notadamente em seu item 2. Em verdade, as respostas buscadas nesta etapa emergem como relevantes exatamente porque suscitam o dever público de perquirir todas as possíveis alternativas disponíveis antes de editar norma de caráter regulatório. Nos termos do dispositivo mencionado, deve o elaborador da medida regulatória responder os seguintes questionamentos: quais as alternativas disponíveis?; quais os resultados das análises do problema verificado?;

\footnotetext{
${ }^{349}$ Sobre o tema da utilização de mecanismos de soft law pela Administração Pública e sua inserção no conceito de legalidade administrativa, ver por todos OTERO, Paulo, Legalidade e Administração Pública, op. cit. , páginas 908-915.
} 
quais instrumentos se mostram adequados a alcançar o que se pretende, no todo ou em parte, tendo em vista o desgaste e encargos para os cidadãos e a economia, custos para o Poder Público, efeitos jurídicos e colaterais, bem como a aceitação por parte dos atores envolvidos?; bem como quais possibilidades de questionamento ao Judiciário?

Portanto, o que se quer aqui dizer é que nenhuma alternativa teoricamente apta a alcançar os objetivos intentados deve ser descartada pela Administração. Independente de sua natureza ou estrutura jurídica, todas as soluções viáveis devem ser agrupadas pelo Poder Público no sentido de configurarem hipóteses regulatórias teoricamente aptas e implementáveis no caso concreto.

\section{IV.3.c. Realização de consultas públicas sobre as diferentes alternativas regulatórias}

Em terceiro lugar, parece ser o momento adequado para inserir o setor privado na discussão. Quer dizer, avaliados os problemas e identificadas as necessidades concretas, bem como elencadas as possíveis alternativas regulatórias aptas a alcançar o que pretende a Administração Pública, surge a necessidade de consultar o mercado para saber o que poder ser implementado com um nível de intervenção razoável e proporcional. Aqui, portanto, reinsere-se o tema das consultas públicas ${ }^{350}$ com os agentes privados e demais particulares eventualmente afetados pela regulação.

E da mesma forma como já de há muito se prega em relação a todo o processo de rulemaking regulatório no Brasil e mesmo de produção de políticas públicas $^{351}$, as consultas públicas aqui vislumbradas devem ser procedidas de forma

\footnotetext{
${ }^{350}$ Conforme anota Marcos Augusto PEREZ, "a consulta pública consiste em procedimento de divulgação prévia de minutas de atos normativos (de interesse geral), visando que, no prazo determinado pela Administração (no caso analisado, no mínimo de dez dias), todos os eventuais interessados ofereçam críticas, sugestões de aperfeiçoamento ou peçam informações e resolvam dúvidas a seu respeito. A Administração tem o dever de documentar todas as consultas e respondê-las publicamente, antes de tomar sua decisão final, de modo a instruir e fundamentar o processo decisório." (A Administração Pública Democrática, Belo Horizonte: Fórum, 2004, página 177)

${ }^{351}$ Nesse sentido, dizia-nos há algum tempo Maria Paula Dallari BUCCI que "o adjetivo 'pública', justaposto ao substantivo 'política', deve indicar tanto os destinatários como os autores da política. Uma política é pública quando contempla os interesses públicos, isto é, da coletividade - não como fórmula justificadora do cuidado diferenciado com interesses particulares ou do descuido indiferenciado de interesses que merecem proteção - mas como realização desejada pela sociedade. Mas uma política pública também deve ser expressão de um processo público, no sentido de abertura à participação de todos os interessados, diretos e indiretos, para a manifestação clara e transparente das posições em jogo." (Direito Administrativo e Políticas Públicas, São Paulo: Saraiva, 2006, página 269)
} 
absolutamente transparente e responsável. Não devem, pois, estimular e nem mesmo admitir participações pro forma ou capturas privadas, mas sim viabilizar uma discussão ampla sobre as diferentes medidas regulatórias vislumbradas e suas distintas incidências, profundidades e níveis de restrição à liberdade comercial dos particulares. Ou seja, trata-se de consultar a iniciativa privada, os segmentos da sociedade civil e os particulares potencialmente afetados sobre a possibilidade, viabilidade, condições e prejudicialidade de cada proposta regulatória em face das capacidades dos atores privados de alcançar as metas regulatórias vislumbradas pela Administração Pública.

Aqui é importante destacar que as consultas ao setor regulado, sejam empresas que exercem a atividade econômica objeto da proposta de regulação ou consumidores e seus órgãos representantes, não têm apenas a ver com a legitimação procedimental da atividade regulatória ou com a transparência. Partindo do pressuposto de que se está diante de um processo de Análise de Impacto Regulatório, o qual tem por objetivo também definir e calibrar a regulação a partir de um vetor de subsidiariedade, a consulta ao setor regulado adquire caráter absolutamente fundamental. Cuida-se, pois, de viabilizar a obtenção de dados indispensáveis ao próprio processo de avaliação, tais como sua efetiva necessidade (ou eventual prescindibilidade), informações sobre custos, benefícios, sugestões sobre outras opções normativas, bem como informações que permitam antever os impactos e os possíveis comportamentos futuros dos destinatários da medida pensada ${ }^{352}$. Visa, acima de tudo, a assegurar a melhor escolha regulatória possível, daí o sentido de se pregar a necessidade de um "reforço da previsão e da efetivação dos instrumentos de participação popular (audiências e consultas públicas) na formulação e no controle dos atos regulatórios, inclusive no procedimento da AIR" $^{\prime 353}$.

Nessa linha, mostra-se particularmente interessante a opinião de Patrícia Rodrigues PESSÔA VALENTE, a qual defende no processo de AIR a realização de três etapas consultivas. A primeira viria logo após a identificação das incapacidades em determinado setor, tendo como finalidade "corrigir eventuais erros $e$ validar a definição do problema e as premissas assumidas (...). Dessa forma, a fase

\footnotetext{
${ }^{352}$ Cf. MORAIS, Carlos Blanco de (coord.), Guia de Avaliação de Impacto Normativo, Coimbra: Almedina, 2010, páginas 39-40.

${ }^{353}$ Cf. OLIVEIRA, Rafael Carvalho Rezende, Governança e Análise de Impacto Regulatório, op. cit., página 202.
} 
inicial de participação do público permite que o tomador de decisão confirme o problema definido, a linha do tempo proposta e ainda os objetivos, a fim de que possa refiná-los para as próximas etapas." ${ }^{354}$ Já a segunda consulta seria justamente para debater as opções regulatórias vislumbradas, hipótese em que podem ser realizadas inclusive dinâmicas de grupos. Para a autora, trata-se do:

"[S]egundo mecanismo de participação dos possíveis afetados $e$ interessados. Nela estão presentes a realização de audiências públicas, de dinâmicas de grupos (focus group), e de pesquisas com entidades estratégicas. Além de conferir maior publicidade e transparência nesse momento em que as opiniões e sugestões serão ouvidas a respeito das opções e método escolhidos, a ideia também é coletar informações sobre custos e benefícios que não seja possivel obter passivamente. ${ }^{1355}$

Segundo a autora, somente passada essa etapa é que a Administração Pública deverá proceder à análise das opções disponíveis de acordo com o método escolhido, inclusive contabilizando os benefícios e custos de cada uma. Não obstante, feito o cotejamento das possibilidades e feira a escolha de uma delas, deve a Administração Pública elaborar uma minuta de relatório da AIR e da política regulatória adotada, submetendo tais documentos à terceira consulta pública. Segundo aponta, "não basta a realização da consulta pública, é preciso ainda responder às sugestões formuladas para estabelecer uma relação de confiança entre a sociedade afetada e o agente regulador. Do contrário, a participação tende a ser reduzida sem que se produza qualquer estímulo para que se participe nos próximos procedimentos" ${ }^{\prime \prime 56}$.

A par disso, defende Patrícia Rodrigues PESSÔA VALENTE ser possível ainda realizar alguns testes práticos, submetendo a proposta regulatória a algumas empresas pequenas ou médias do setor regulado de modo testar na prática do dia a dia as escolhas realizadas. Em sua opinião, "[e]ssa prática é muito comum em outras áreas de conhecimento como a comunicação social e administração de empresas. Afinal, não é suficiente se perguntar se é preferivel impor uma conduta por

\footnotetext{
${ }^{354}$ A análise de impacto como mecanismo de controle do tabaco, op. cit., página 124.

${ }^{355}$ A análise de impacto como mecanismo de controle do tabaco, op. cit., páginas 125-126.

${ }^{356} \mathrm{Cf}$. A análise de impacto como mecanismo de controle do tabaco, op. cit., páginas 126-127.
} 
meio de prescrições, ou instituir estímulos que a favoreçam. Deve-se também testar as escolhas" $^{357}$.

Independentemente do acerto ou erro dessa proposta, fato é que a intensa comunicação entre regulador e setor regulado configura preocupação das mais relevantes, a qual somente deve se encerrar com a efetiva edição da norma regulatória ${ }^{358}$. Um processo de AIR que se pretenda sério e efetivo, notadamente respeitando a subsidiariedade da intervenção estatal, demanda a realização de um procedimento complexo e dotado de um nível de expertise do regulador e de articulação com o setor regulado bastante intenso e transparente. Embora difícil, trabalhoso e de certa forma também custoso, não se trata de medida despropositada. Ao contrário, regular a economia é uma das atividades estatais mais relevante, e não há sentido em não empreender esforços institucionais para a melhora de sua qualidade.

\section{IV.3.d. A importância de escolha regulatória consciente e respeitadora da autossuficiência privada}

Por fim, em quarto lugar, há efetivamente a escolha da medida regulatória a ser implantada pela Administração, momento em que, a prevalecer um critério de coerência, proporcionalidade e racionalidade, todos os elementos já apresentados deverão ser colocados em prática. É dizer, não apenas a condução das pesquisas, estudos e debates públicos, mas, acima de tudo, o fundamento da decisão administrativa sobre qual medida regulatória será adotada deve levar em conta o respeito à suficiência privada na implementação da pauta de interesse público pretendida.

De todo modo, há que se reconhecer que o cumprimento das etapas pretéritas até agora vistas garante o acesso às informações sobre as melhores alternativas à disposição da Administração Pública, seus custos e benefícios, quais restringem mais ou menos a liberdade de iniciativa dos atores privados e, acima de tudo, quais podem ser efetivamente concretizados pelo mercado e quais não podem.

\footnotetext{
${ }^{357}$ Cf. A análise de impacto como mecanismo de controle do tabaco, op. cit., página 127.

${ }^{358}$ Cf. MORAIS, Carlos Blanco de (coord.), Guia de Avaliação de Impacto Normativo, op. cit., página 40.
} 
Entretanto, a decisão acerca da medida regulatória a ser tomada é o momento de efetivação do vetor de subsidiariedade que incide na intervenção regulatória administrativa e, ainda assim, não se pode negar que se trata de ato que envolve certa carga de discricionariedade conferida ao órgão administrativo dotado da competência regulatória. E aqui não estamos falando da chamada discricionariedade técnica (que a nosso ver, ou se trata de discricionariedade pura ou não existe ${ }^{359}$ ) nem muito menos daquela outra mais vetusta, que pregava a absoluta incontrolabilidade dos atos administrativos ditos discricionários.

De nossa parte, embora plenamente controláveis por conta dos mecanismos tradicionais e principiológicos mais modernos ${ }^{360}$, fato é que a decisão sobre qual medida regulatória adotar e com qual intensidade é matéria reservada ao órgão administrativo regulador. Quer dizer, todas as exigências procedimentais inseridas num processo de AIR conforme aqui suscitados não retiram do regulador a competência exclusiva de dizer a palavra final sobre a regulação incidente na realidade. O que muda com a Análise de Impacto Regulatório, em nossa opinião, é o acometimento de uma pauta ainda maior de controlabilidade, justamente pela incidência de uma maior procedimentalização da atividade (para além da processualização natural incidente no rulemaking regulatório), em que se "propicia o conhecimento do que ocorreu antes que o ato faça repercutir, sobre os indivíduos, os seus efeitos, permitindo verificar, por conseguinte, como se realiza a tomada de decisões; e assim contribui para conferir-lhe maior grau de objetividade" ${ }^{361}$.

359 Sobre o tema da inexistência de discricionariedade técnica ver nosso Discricionariedade administrativa, regulação econômica e a proposta de Regulamento de Aplicações de Sanções Administrativas da ANATEL, in Revista de Direito de Informática e Telecomunicações - RDIT, ano 5, $\mathrm{n}^{\circ}$ 9, Belo Horizonte: Fórum, jul/dez 2010, páginas 24-26.

${ }^{360}$ Referimo-nos aqui à possibilidade de controle da discricionariedade administrativa a partir dos vetores da teoria dos atos administrativos com a sindicação dos vinculados, da teoria dos motivos determinantes, da teoria do desvio de poder, da entronização dos princípios jurídicos do discurso estatal (em especial a eficiência), das regras da proporcionalidade e da razoabilidade e da procedimentalização da atividade administrativa, com especial atenção ao dever sempre crescente de motivação das escolhas estatais. Sobre esse ponto ver nossos Discricionariedade administrativa, regulação econômica e a proposta de Regulamento de Aplicações de Sanções Administrativas da ANATEL, op. cit., páginas 10-14; e Discricionariedade Administrativa e Interesses Públicos: superando a supremacia em busca da ponderação, in Fórum Administrativo, ano 11, n 122, Belo Horizonte: Fórum: abr/2011, páginas 1819. Entretanto, para uma visão completa do tema da discricionariedade administrativa incidente nos atos regulatórios ver por todos GUERRA, Sérgio, Controle Judicial dos Atos Regulatórios, Rio de Janeiro: Lumen Juris, 2005, páginas 161-246; e do mesmo autor Discricionariedade e Reflexividade: uma nova teoria sobre as escolhas administrativas, Belo Horizonte: Fórum, 2008, páginas 123-264.

${ }^{361}$ Cf. MEDAUAR, Odete, O Direito Administrativo em Evolução, op. cit., página 224. 
Não obstante, no que respeita ao vetor da subsidiariedade da intervenção regulatória, a procedimentalização reforçada resultado da AIR torna seu eventual desrespeito pelo órgão administrativo regulador altamente sindicável. Ora, identificar um problema em determinado setor da economia, apontar soluções alternativas viáveis à sua resolução e discuti-las abertamente com os atores privados e possíveis afetados são elementos que acabam de certa forma vinculando a decisão final da Administração em uma que efetivamente respeite o vetor de subsidiariedade da intervenção estatal exaustivamente discutido acima. Isso porque, assentada a subsidiariedade como um vetor de obrigatória observância pelo corpo estatal (conforme entendemos e aqui defendemos), qualquer decisão regulatória que se mostre em alguma medida desrespeitadora da suficiência dos particulares pode ser logicamente questionada até mesmo em sede judicial.

Portanto, a incidência da Análise de Impacto Regulatória - AIR na regulação administrativa da economia, de novo, e nos termos do quanto aqui defendido, resume-se à uma maior procedimentalização e ao fato de proporcionar amplos mecanismos de garantia do vetor da subsidiariedade da intervenção estatal regulatória perpetrada pela Administração Pública. 


\section{CONCLUSÃO}

$\mathrm{O}$ adequado relacionamento entre esfera pública e esfera privada, em um sentido de complementaridade e equilíbrio, dizia-nos Nelson SALDANHA em um pequeno texto publicado em 1983, tem importância substancial para a própria existência humana. Fazendo uma interessante alusão ao jardim e à praça como espaços respectivamente privados e públicos, tratava o autor das vertentes público e privada inseridas em cada membro da sociedade ${ }^{362}$.

Transpondo essa premissa ao tema do relacionamento entre particulares e Poder Público, notadamente entre Administração Pública e a livre iniciativa em termos de regulação econômica, seria possível pensar também que um adequado balanceamento entre esses elementos, sob uma perspectiva de equilíbrio e complementaridade, é fundamental para a coexistência social e econômica dos indivíduos. Nesse sentido, ter em conta que (i) o mercado configura espaço por definição privado, (ii) que a livre iniciativa é garantida como um direito fundamental dos indivíduos e (iii) que ao Poder Público somente é autorizado agir mediante uma função pública, instituída por lei e apta a perquirir determinado interesse público objetivamente delimitado, implica em elevar o respeito à eventual autossuficiência privada em atingir pautas públicas à condição de preocupação basilar da atividade estatal.

Nesse sentido, o presente trabalho buscou demonstrar e fundamentar que a subsidiariedade, aqui defendida como um vetor de limitação que somente legitima a intervenção estatal quando comprovada a impossibilidade de que os particulares atinjam os mesmo fins públicos buscados de forma autônoma, figura como limite objetivo à intervenção regulatória da econômica perpetrada pela Administração Pública.

Isso, entretanto, nada diz com um hipotético tamanho ideal do aparato estatal ou de um nível supostamente adequado de intervenção regulatória, matérias que, como se sabe, não estão definidas em tese na Constituição e dependem da vontade das maiorias. A subsidiariedade aqui defendida funciona como uma regra procedimental: havendo a necessidade de garantir determinada finalidade de interesse público em um

362 O Jardim e a Praça: ensaio sobre o lado "privado" e o lado "público" da vida social e história, in Ciência \& Trópico, $\mathrm{n}^{\circ}$ 11, Recife: Massangana, jan/jul 1983, página 117. 
setor da economia (matéria esta de amplo alcance, ainda que limitada pelos objetivos instituídos no artigo 170 da Constituição Federal), deve a Administração Pública perquirir se os atores privados seriam, e em que medida, aptos a garantir a implementação destes objetivos de forma autônoma. Trata-se, pois, de um vetor de subsidiariedade que serve como requisito de legitimidade da atividade regulatória a cargo da Administração Pública, a qual é fundada em elementos de ordem teórica, constitucional e jurídico-administrativa.

Para além de mero esforço retórico, pretendeu-se comprovar que dentro do chamado rulemaking regulatório, o instrumento naturalmente vocacionado para se efetivar o vetor da subsidiariedade é a intitulada Análise de Impacto Regulatório - AIR, que se trata de uma espécie de procedimento prévio à instituição de qualquer norma regulatória e que tem por objetivo basicamente vislumbrar as alternativas viáveis a atingir os objetivos buscados pelo Poder Público e avaliar, dentro de uma perspectiva ampla, qual a melhor opção disponível. Partindo do pressuposto que já existem fundamentos robustos para a instituição da AIR no Brasil, foram delimitadas algumas pautas procedimentais, em caráter propositivo, de forma a proporcionar uma adequada efetivação deste vetor de subsidiariedade na regulação administrativa da economia.

Conquanto plenamente justificável do ponto de vista jurídico, o efetivo respeito à autonomia privada e o reconhecimento da importância dos atores privados na implementação de interesses públicos legítimos demanda alguma mudança de concepção da própria sociedade. O que acima se fez foi apenas demonstrar alguns equívocos e apresentar vetores e alternativas mediante as quais esse cenário poderia se modificar. A efetiva mudança, parece-nos, depende de todos, reguladores, particulares atuantes e todos os afetados por cada medida regulatória imposta em face da economia brasileira. 


\section{BIBLIOGRAFIA}

ADDISON, Tony e CORNIA, Giovanni Andrea. Income Distribution Policies For Faster Poverty Reduction. In United Nations University - World Institute for Development Economics Research - UNU- WIDER. Discussion Paper $\mathrm{n}^{\circ}$ 93/2001. Disponível em: http://www.wider.unu.edu/publications/workingpapers/discussion-papers/2001/en_GB/dp2001-93/_files/78091898299943842/ default/dp2001-93.pdf.

ALEMANY, Macário. El concepto y la justificación del paternalismo. In DOXA, Cuadernos de Filosofia del Derecho, $n^{\circ} 28$. Alicante: Universidad de Alicante, 2005, páginas 265-303.

ALESSI, Renato. Instituciones de Derecho Administrativo, tomo II. Barcelona: Bosch, 1970.

ALEXY, Robert. Teoria da Argumentação Jurídica: a teoria do discurso racional como teoria da justificação jurídica. $2^{\mathrm{a}}$ ed. São Paulo: Landy Editora, 2005.

2008.

. Teoria dos Direitos Fundamentais. São Paulo: Malheiros Editores,

ALFONSO, Luciano Parejo. Derecho Administrativo. Barcelona: Ariel, 2003.

ALMEIDA, Fernando Dias Menezes de. Teoria da Regulação. In CARDOZO, José Eduardo Martins, QUEIROZ, João Eduardo Lopez e SANTOS, Márcia Walquiria Batista dos (orgs), Curso de Direito Administrativo Econômico, vol. III. São Paulo: Malheiros Editores, 2006, páginas 119-148.

AMARAL NETO, Francisco dos Santos. A liberdade de iniciativa econômica: fundamento, natureza e garantia constitucional. In Revista de Informação Legislativa, v. 23, n 92. Brasília: Senado Federal, out/dez 1986, páginas 221240.

ARAGÃO, Alexandre Santos. Direito dos Serviços Públicos, $2^{\text {a }}$ ed. Rio de Janeiro: Forense, 2008.

Agências Reguladoras e a Evolução do Direito Administrativo Econômico, $2^{a}$ ed. Rio de Janeiro: Forense, 2006.

Princípio da Legalidade e Poder Regulamentar no Estado Contemporâneo. In Revista Trimestral de Direito Público - RTDP, $n^{\circ}$ 38. São Paulo: Malheiros Editores, 2002, páginas 82-98. 
Liberdade de Expressão Comercial. In Revista de Direito Público da Economia - RDPE, ano 3, n 11. Belo Horizonte: Fórum, jul/set. 2005, páginas $33-62$.

. O Princípio da Proporcionalidade no Direito Econômico. In Revista de Direito Administrativo, $\mathrm{n}^{\circ}$ 223. Rio de Janeiro: Renovar, jan/mar 2001, páginas 199-230.

. Análise de Impacto Regulatório - AIR. In Revista de Direito Público da Economia - RDPE, n 32. Belo Horizonte: Fórum, out/dez 2010, páginas 915.

ARISTÓTELES. A Política, $2^{\text {a }}$ ed. Bauru: Edipro, 2009.

ÁVILA, Humberto. Teoria dos Princípios - da definição à aplicação dos princípios jurídicos, $9^{\text {a }}$ ed. São Paulo: Malheiros Editores, 2009.

BANDEIRA DE MELlO, Celso Antônio. Curso de Direito Administrativo, $29^{\mathrm{a}}$ ed. São Paulo: Malheiros Editores, 2012.

BARACHO, José Alfredo de Oliveira. O Princípio de Subsidiariedade: conceito e evolução. Rio de Janeiro: Forense, 1997.

BARCELlOS, Ana Paula de. Ponderação, Racionalidade e Atividade Jurisdicional. Rio de Janeiro: Renovar, 2005.

BARROSO, Luís Roberto. Interpretação e Aplicação da Constituição, $7^{a}$ ed. São Paulo: Saraiva, 2009.

BASTOS, Celso Ribeiro. Curso de Direito Constitucional, 22a ed. São Paulo: Malheiros Editores, 2010.

BASTOS, Celso Ribeiro e MARTINS, Ives Gandra. Comentários à Constituição do Brasil, v. 7. São Paulo: Saraiva, 1990.

BRASIL, Ministério das Comunicações. Exposição de Motivos no 231. Dez/1996.

BENTHAM, Jeremy. An Introduction to Principles of Morals and Legislation, vol. I. Londres: W. Pickering, 1823.

BERCOVICI, Gilberto. Direito Econômico do Petróleo e dos Recursos Minerais. São Paulo: Quartier Latin, 2011.

Os Princípios Estruturantes e o Papel do Estado, in CARDOSO JR, José Celso (org.), A Constituição Brasileira de 1988 Revisitada: recuperação 
histórica e desafios atuais das políticas públicas nas áreas econômica e social, Vol. 1, Brasília: IPEA, 2009, páginas 255-291.

BERGAMINI CUNHA, Carlos Eduardo. Discricionariedade Administrativa $e$ Interesses Públicos: superando a supremacia em busca da ponderação. In Fórum Administrativo, ano 11, n 122. Belo Horizonte: Fórum: abr/2011, páginas 9-21.

Conceito de princípio jurídico e seus impactos no Direito Público contemporâneo: o caso da dispensa de licitação lastreada no inciso XIII do artigo 24 da Lei $n^{o}$ 8.666/93, in Revista de Direito Administrativo e Constitucional, ano 11, n 43, Belo Horizonte: Fórum, jan/mar 2011, páginas 167-196.

Discricionariedade administrativa, regulação econômica e a proposta de Regulamento de Aplicações de Sanções Administrativas da ANATEL. In Revista de Direito de Informática e Telecomunicações - RDIT, ano 5, n 9. Belo Horizonte: Fórum, jul/dez 2010, páginas 9-32.

BINENBOJM, Gustavo. Agências Reguladoras, Legalidade e Direitos Fundamentais Limites aos Poderes Normativo e Sancionatório da Anvisa na Regulação de Produtos Fumígenos. In ARAGÃO, Alexandre Santos de (org.), O Poder Normativo das Agências Reguladoras. Rio de Janeiro: Forense, 2006, páginas 637-672.

BINENBOJM, Gustavo (coord.). Agências Reguladoras e Democracia. Rio de Janeiro: Lumen Juris, 2006.

BOBBIO, Norberto. Da Estrutura à Função: novos estudos de teoria do direito. São Paulo: Manole, 2007.

Teoria do Ordenamento Jurídico, $6^{a}$ ed. Brasília: Universidade de Brasília, 1995.

- Direita e Esquerda: razões e significações de uma distinção particular, $3^{\mathrm{a}}$ ed. São Paulo: UNESP, 2011.

BONAVIDES, Paulo. Curso de Direito Constitucional, $23^{\mathrm{a}}$ ed. São Paulo: Malheiros Editores, 2008.

. Teoria Geral do Estado, $8^{\mathrm{a}}$ ed., São Paulo: Malheiros Editores, 2010.

BOROWSKI, Martin. La Estructura de los Derechos Fundamentales. Colômbia: Universidad Externado de Colombia, 2006.

BUCCI, Maria Paula Dallari. Direito Administrativo e Políticas Públicas. São Paulo: Saraiva, 2006. 
BOYLER, Robert. Teoria da Regulação: os fundamentos. São Paulo: Estação Liberdade, 2009.

BRESSER PEREIRA, Luiz Carlos. O caráter cíclico da intervenção estatal. In Revista de Economia Política, vol. 9, n 3. São Paulo: Editora 34, jul/set 1989, páginas 115-130.

CÂMARA, Jacintho Arrida. As autorizações da Lei Geral de Telecomunicações e a Teoria Geral do Direito Administrativo. In Revista de Direito de Informática e Telecomunicações - RDIT, no 3. Belo Horizonte: Fórum, jul/dez 2003, páginas 55-68.

- A Nova Regulamentação do Serviço de Telefonia Celular - Serviço Móvel Pessoal: O Sucedâneo do Serviço Móvel Celular. In Fórum Administrativo, $\mathrm{n}^{\circ}$ 5. Belo Horizonte: jul/2001, páginas 588-594.

CANOTILHO, José Joaquim Gomes. Direito Constitucional e Teoria da Constituiçãa, $7^{\mathrm{a}}$ ed. Coimbra: Almedina, 2007.

"Metodologia Fuzzy" e "Camaleões Normativos" na Problemática Actual dos Direitos Económicos, Sociais e Culturais. In Estudos sobre Direitos Fundamentais. São Paulo: Revista dos Tribunais, 2008, páginas 97-113.

CANOTILHO, José Joaquim Gomes e MOREIRA, Vital. Constituição da República Portuguesa - Anotada e Comentada, $3^{\text {a }}$ ed. Lisboa: Coimbra Editora, 1993.

CAVAlCANTI, Themístocles Brandão. Tratado de Direito Administrativo, tomo I, $2^{a}$ ed. Rio de Janeiro: Editora Freitas Bastos, 1948.

Curso de Direito Administrativo, $6^{a}$ ed., Rio de Janeiro: Editora Freitas Bastos, 1961.

CHEVALlIER, Jacques. La Régulation Juridique en Question, in Droit et Societé, $\mathrm{n}^{\circ}$ 49. Paris: LGDJ, 2001, páginas 827-846.

. O Estado Pós-Moderno, Belo Horizonte: Fórum, 2009

COMPARATO, Fábio Konder. O Indispensável Direito Econômico. In Ensaios e Pareceres de Direito Empresarial. Rio de Janeiro: Forense, 1978, páginas 453472.

CORREIA, José Manuel Sérvulo. Legalidade e Autonomia Contratual nos Contratos Administrativos. Coimbra: Almedina, 1987. 
COUTINHO, Diogo R. Linking Promises to Policies: Law and Development in an Unequal Brazil. In The Law and Development Review, vol. 3, $\mathrm{n}^{\mathrm{o}}$ 2, Berkeley. Disponível em: $\quad$ http://www.law.wisc.edu/gls/documents/diogo_coutinho_pa per.pdf.

CYRINO, André Rodrigues. Direito Constitucional Regulatório. Rio de Janeiro: Renovar, 2010.

D’ALTE, Sofia Tomé. A Nova Configuração do Sector Empresarial do Estado e a Empresarialização dos Serviços Públicos. Coimbra: Almedina, 2007.

DI PIETRO, Maria Sylvia Zanella. Direito Administrativo. $25^{\mathrm{a}}$ ed. São Paulo: Atlas, 2012.

Limites da Função Reguladora das Agências diante do Princípio da Legalidade. In DI PIETRO, Maria Sylvia (org.), Direito Regulatório: temas polêmicos, $2^{\mathrm{a}}$ ed. Belo Horizonte: Fórum, 2009, páginas 19-50.

O direito administrativo brasileiro sob influência dos sistemas de base romanística e da common law. In Revista Brasileira de Direito Público RBDP, ano 5, $\mathrm{n}^{\circ}$ 16, Belo Horizonte: Fórum, jan/mar 2007, páginas 9-30.

DROMI, Roberto. Derecho Administrativo, $11^{\text {a }}$ ed. Buenos Aires: Ciudad Argentina: 2006.

DWORKIN, Gerald. Moral Paternalism. In Law and Philosophy, vol. 24, $\mathrm{n}^{\circ}$ 3: Springer Netherlands, mai/2005, páginas 305-319.

DWORKIN, Ronald. A Virtude Soberana. São Paulo: Martins Fontes, 2005.

1978.

Taking Rights Seriously. Massachusetts: Harvard University Press,

ELY, John Hart. Democracy and Distrust: A Theory of Judicial Review. Cambridge: Harvard University Press, 2002.

ENTERRÍA, Eduardo Garcia de e FERNÁNDEZ, Tomás-Ramón. Curso de Derecho Administrativo, vol. II, $11^{\text {a }}$ ed. Madrid: Civitas, 2008.

FAORO, Raymundo. Os Donos do Poder, $4^{\mathrm{a}}$ ed. São Paulo: Globo, 2008.

FARACO, Alexandre Ditzel, PEREIRA NETO, Caio Mario da Silva e COUTINHO, Diogo Rosenthal. Universalização das Telecomunicações: Uma Tarefa Inacabada. In Revista de Direito Público da Economia - RDPE, no 2. Belo Horizonte: Fórum, abr/jun 2003, páginas 9-58. 
FARACO, Carlos Alberto (org.). Estrangeirismos: guerras em torno da língua. São Paulo: Parábola, 2001.

FARIA, José Eduardo (org.). Regulação, Direito e Democracia. São Paulo: Editora Fundação Perseu Abramo, 2002.

FELIÚ, José María Gimenu. Legalidad, Transparencia, Control y Discrecionalidad en las Medidas de Fomento del Desarrollo Económico. In Revista de Administración Pública, $\mathrm{n}^{\circ}$ 137. Madrid: Centro de Estudios Políticos y Constitucionales, mai/ago 1995, páginas 147-187.

FERRAZ JÚNIOR, Tércio Sampaio. Fundamentos e Limites Constitucionais da Intervenção do Estado no Domínio Econômico. In Revista de Direito Público RDP, $\mathrm{n}^{\text {os }}$ 47-48. São Paulo: Revista dos Tribunais, 1978, páginas 261-272.

- Congelamento de Preços - Tabelamentos Oficiais. In Revista de Direito Público - RDP, vol. 22, n ${ }^{\circ}$ 1. São Paulo: Revista dos Tribunais, jul/set 1989, páginas 76-86.

FERREIRA FILHO, Manoel Gonçalves. Curso de Direito Constitucional, $35^{a}$ ed. São Paulo: Saraiva, 2009.

FIGUEIREDO, Lúcia Valle. Curso de Direito Administrativo. $9^{\mathrm{a}}$ ed. São Paulo: Malheiros Editores, 2008.

FRANCO, Alberto Silva, Código Penal e sua Interpretação, $8^{\mathrm{a}}$ ed., São Paulo: Revista dos Tribunais, 2007.

FUGUITT, Diana e WILCOX, Shanton J. Cost-Benefit Analysis for Public Sector Decision Makers. Westport: Quorum Books, 1999.

GABARDO, Emerson. Interesse Público e Subsidiariedade. Belo Horizonte: Fórum, 2009.

GAETANI, Francisco e ALBUQUERQUE, Kélvia. Análise de Impacto Regulatório e Melhoria Regulatória. In RAMALHO, Pedro Ivo Sebba (org.), Regulação e Agências Reguladoras: Governança e Análise de Impacto Regulatório. Brasília: Anvisa, 2009, páginas 189-196.

GIANNINI, Massimo Severo. Diritto Amministrativo, vol. I. 2 ed. Milão: Giuffrè, 1988.

Premissas Sociológicas e Históricas del Derecho Administrativo. Madrid: Instituto Nacional de Administración Pública - INAP, 1980. 
GONÇALVES, Marcos Peixoto Mello. Direito e Economia: Democracia Política e Economia. São Paulo: Quartier Latin, 2009.

GONÇALVES, Pedro António P. Costa. Regulação Administrativa e Contrato. In Revista de Direito Público da Economia - RDPE, ano 9, ${ }^{\circ} 35$. Belo Horizonte: Fórum, jul/set 2011, páginas 105-141.

Estado de Garantia e Mercado. In SADDY, A. E MARTÍNEZ, Aurilivi Linares (coords.), Direito das Infraestruturas: um estudo dos distintos mercados regulados. Rio de Janeiro: Lumen Juris, 2011, páginas 23-46.

GRAU, Eros Roberto. A Ordem Econômica na Constituição de 1988. $12^{\mathrm{a}}$ ed. São Paulo: Malheiros Editores, 2007.

GRECO, Luís. Subsidiariedade (no Direito Penal), in TORRES, Ricardo Lobo et. al (orgs.), Dicionário de Princípios Jurídicos, Rio de Janeiro: Elsevier, 2011, páginas 1277-1291.

GROTTI, Dinorá Adelaide Musetti. As Agências Reguladoras. In Revista Brasileira de Direito Público - RBDP, ano 2, $\mathrm{n}^{\circ}$ 4. Belo Horizonte: Fórum, jan/mar 2004, páginas 187-219.

GUERRA, Sérgio. Introdução às Agências Reguladoras. Rio de Janeiro: Freitas Bastos, 2004. Juris, 2005.

Controle Judicial dos Atos Regulatórios. Rio de Janeiro: Lumen

Discricionariedade e Reflexividade: uma nova teoria sobre as escolhas administrativas. Belo Horizonte: Fórum, 2008.

HABERMAS, Jürgen. Direito e Democracia: entre facticidade e validade, vol. II. Rio de janeiro: Tempo Brasileiro, 2003.

HAHN, Robert W. State and Federal Regulatory Reform: a comparative analysis. In ADLER, Matthew D. e POSNER, Eric A. (ed.), Cost-Benefit Analysis: Legal, Economic and Philosophical Perspectives. Chicago: The University of Chicago Press, 2000, páginas 37-76.

HAHN, Robert e TETLOCK, Paul. Has Economic Analysis Improved Regulatory Decisions? In AEI-Brookings Joint Center, working paper $n^{\circ}$ 07-08, abr/2007. Disponível em: http://ssrn.com/abstract=982233.

HAURIOU, Maurice. Principios de Derecho Público y Constitucional. Madrid: Instituto Editorial Reus, 1927. 
HARSANYI, David. O Estado Babá. Rio de Janeiro: Litteris, 2011.

HERR, Teodor. La Dottrina Sociale Della Chiesa. Manuale di base. Piemme: G. Angelini, 1988.

HUNT, E. K. História do Pensamento Econômico. $2^{\mathrm{a}}$ ed. Rio de Janeiro: Elsevier, 2005.

HUSAK, Douglas. Paternalism and Autonomy. In Philosophy \& Public Affairs, vol. 10. Hoboken: Wiley, 1981, páginas 27.46.

IGLESIAS, Gema Rosado. La titularidad de derechos fundamentales por la persona jurídica. Valência: Tirant Lo Banch, 2004.

JIMÉNEZ, Luis Arroyo, Ponderación, Proporcionalidad y Derecho Administrativo, in ORTEGA, Luis e SIERRA, Susana de la (coords.), Ponderación y Derecho Administrativo. Madrid: Marcial Pons, 2009, páginas 19-49.

JORDANA DE POZAS, Luis. Ensayo de una teoría del fomento en el Derecho administrativo. In Revista de Estudios Políticos, $\mathrm{n}^{\circ}$ 48. Madrid: Centro de Estudios Políticos y Constitucionales, nov/dec 1949, páginas 41-54.

JUSTEN FILHO, Marçal. Curso de Direito Administrativo, $8^{\mathrm{a}}$ ed. Belo Horizonte: Fórum, 2012.

Agências Reguladoras e Democracia: Existe um Déficit Democrático na "Regulação Independente"? In ARAGÃO, Alexandre Santos de (org.), O Poder Normativo das Agências Reguladoras. Rio de Janeiro: Forense, 2006, páginas 301-332.

O Direito das Agências Reguladoras Independentes. São Paulo: Dialética, 2002.

KENNEDY, David. The "Rule of Law," Political Choices, and Development Common Sense. In TRUBEK, David, M. e SANTOS, Alvaro (ed.), The New Law and Economic Development: A Critical Appraisal. New York: Cambridge University Press, 2006, páginas 95-173.

KUTTNER, Robert. Everything for Sale: the virtues and limits of markets. Nova York: The University of Chicago Press, 1999.

LAPOINTE, Benoît. Le principe de subsidiarité sous l'éclairage de l'enseignement social de l'Eglise. In CHEVALLIER, Jacques (coord.), L'identité politique. Paris: PUF, 1994, páginas 445-460. 
LEAL, Rosemiro Pereira. Curso de Direito Econômico-Comunitário. Porto Alegre: Síntese, 2001.

LOSS, Giovani Ribeiro. A Regulação Setorial do Gás Natural. Belo Horizonte: Fórum, 2007.

MALDONADO, Carlos Eduardo. Human Rights, Solidarity and Subsidiarity: Essays toward a Social Ontology. Washington: RVP, 1997.

MARQUES NETO, Floriano de Azevedo. O Fomento como Instrumento de Intervenção Estatal na Ordem Econômica. In Revista de Direito Público da Economia RDPE, ano 8, n 32. Belo Horizonte: Fórum, out/dez 2010, páginas 57-71.

Universalização de Serviços Públicos e Competição: o caso da distribuição de gás natural. In Revista Trimestral de Direito Público - RTDP, $\mathrm{n}{ }^{\circ}$ 34. Rio de Janeiro: Malheiros Editores, 2001, páginas 34-50.

A Nova Regulação dos Serviços Públicos. In Revista de Direito Administrativo - RDA, vol. 228. Rio de Janeiro: Renovar, 2002, páginas 13-29.

Regulação Econômica e suas Modulações. In Revista de Direito Público da Economia - RDPE, ano 7, $\mathrm{n}^{\circ}$ 28. Belo Horizonte: Fórum, out/dez 2009, páginas 27-42.

Regulação Setorial e Autoridade Antitruste: A Importância da Independência do Regulador. In CAMPLILONGO, Celso Fernandes, ROCHA, Jean Paul C. Veiga da e MATTOS, Paulo Todescan Lessa (coords.), Concorrência e Regulação no Sistema Financeiro. São Paulo: Max Limonad, 2002, páginas 95-118.

. Agências Reguladoras Independentes: Fundamentos e seu Regime Jurídico. Belo Horizonte: Fórum, 2005.

Regulação Estatal e Autorregulação na Economia Contemporânea. In Revista de Direito Público da Economia - RDPE, no 33 . Belo Horizonte: Fórum, jan/mar 2011, páginas 79-94.

Editores, 2002.

Interesses Públicos e Regulação Estatal, São Paulo: Malheiros

Limites à Abrangência e à Intensidade da Regulação Estatal, in Revista de Direito Público da Economia - RDPE, $n^{\circ}$ 1, Belo Horizonte: Fórum, jan/mar 2003, páginas 69-93. 
Interesses Públicos e Privados na Atividade Estatal de Regulação, in MARRARA, Thiago (org.), Princípios de Direito Administrativo, São Paulo: Atlas, 2012, páginas 419-440.

. Direito das Telecomunicações e ANATEL. In SUNDFELD, Carlos Ari (coord.), Direito Administrativo Econômico. São Paulo: Malheiros Editores, 2006, páginas 300-316.

MARQUES NETO, Floriano de Azevedo e QUEIROZ, João Eduardo Lopes. Planejamento. In CARDOZO, José Eduardo Martins et. al. (orgs.), Curso de Direito Administrativo Econômico, vol. II. São Paulo: Malheiros Editores, 2006, páginas 40-127.

MARQUES NETO, Floriano de Azevedo et. al. Há um Déficit Democrático nas Agências Reguladoras? In Revista de Direito Público da Economia - RDPE, $\mathrm{n}^{\circ}$ 5. Belo Horizonte: Fórum, jan/2004, páginas 163-224.

MARTINS, Leonardo. Liberdade e Estado Constitucional, São Paulo: Atlas, 2012.

MARTINS, Margarida Salema d'Oliveira. O Princípio da Subsidiariedade em Perspectiva Jurídico-Política. Coimbra: Coimbra Editora, 2003.

MARTINS, Ricardo Marcondes. Regulação Administrativa à Luz da Constituição Federal. São Paulo: Malheiros Editores, 2011.

MARTINS, Sérgio Pinto. A Terceirização e o Direito do Trabalho. São Paulo: Atlas, 2009.

MATTOS, Paulo Todescan Lessa. O Novo Estado Regulador no Brasil: Eficiência e Legitimidade. São Paulo: Singular, 2006.

Agências Reguladoras e Democracia: participação pública e desenvolvimento. In SALOMÃO FILHO, Calixto (coord.), Regulação e Desenvolvimento. São Paulo: Malheiros Editores, 2002, páginas 182-230.

MAURER, Harmut. Direito Administrativo Geral, 14ª ed. Barueri: Manole, 2005.

MEDAUAR, Odete. O Direito Administrativo em Evolução, $2^{a}$ ed. São Paulo: Revista dos Tribunais, 2003.

A Processualidade no Direito Administrativo, $2^{\mathrm{a}}$ ed., São Paulo: Revista dos Tribunais, 2008.

MENDES, Gilmar Ferreira, COELHO, Inocêncio Mártires e BRANCO, Paulo Gustavo Gonet. Curso de Direito Constitucional, $4^{\mathrm{a}}$ ed. São Paulo: Saraiva, 2009. 
MENDONÇA, José Vicente Santos de. Uma Teoria do Fomento Público: critérios em prol de um fomento público democrático, eficiente e não-paternalista. In Revista de Direito da Procuradoria Geral do Estado do Rio de Janeiro, vol. 65. Rio de Janeiro: Procuradoria-Geral do Estado do Rio de Janeiro 2010, páginas 115-176.

A legitimidade da tutela pública e o cheese salada. In Consultor Jurídico, 29.07.2010. Disponível em: http://www.conjur.com.br/2010-jul29/legitimidade-tutela-publica-cheesesalada.

Direito Constitucional Econômico: A intervenção do Estado na economia à luz da razão pública e do pragmatismo, Rio de Janeiro, 2012, no prelo.

MILL, John Stuart. Sobre a Liberdade. São Paulo: Hedra, 2010.

MILLON-DELSOL, Chantal. Le príncipe de subsidiarité. Paris: PUF, 1993.

L' État Subsidiaire - Ingérence et non-ingérence de l'Etat: le principe de subsidiarité aux fondements de l'histoire européenne. Paris: PUF, 1992.

MIRANDA, Jorge. Teoria do Estado e da Constituição. Coimbra: Coimbra Editora, 2002.

Iniciativa Económica. In Escritos Vários sobre Direitos Fundamentais. Estoril: Princípia Editora, 2006, páginas 173-184.

MONCADA, Luís S. Cabral de. Direito Económico. $4^{\mathrm{a}}$ ed. Coimbra: Coimbra Editora, 2003.

Ensaio sobre a lei. Coimbra: Coimbra Editora, 2002.

MORAES, Alexandre de. Direito Constitucional Administrativo, $4^{\mathrm{a}}$ ed. São Paulo: Atlas, 2007.

Direito Constitucional, 16ª . São Paulo: Atlas, 2004.

MORAIS, Carlos Blanco de. O Princípio da Subsidiariedade na Ordem Constitucional Portuguesa. In BARROS, Sérgio Resende e ZILVETI, Fernando Aurélio (coords.), Direito Constitucional: estudos em homenagem a Manoel Gonçalves Ferreira Filho. São Paulo: Dialética, 1999, páginas 31-66.

2010.

Guia de Avaliação de Impacto Normativo. Coimbra: Almedina, 
MOREIRA, Egon Bockmann. $O$ Direito Administrativo Contemporâneo $e$ a Intervenção do Estado na Ordem Econômica. In WAGNER JÚNIOR, Luiz Guilherme da Costa (coord.), Direito Público: estudos em homenagem ao Professor Adilson Abreu Dallari. Belo Horizonte: Del Rey, 2004, páginas 257281.

O Direito Administrativo da Economia, a Ponderação de Interesses e o Paradigma da Intervenção Sensata. In CUELLAR, Leila e MOREIRA, Egon Bockmann, Estudos de Direito Econômico. Belo Horizonte: Fórum, 2004, páginas 53-98.

Agências reguladoras independentes, déficit democrático $e$ a "elaboração processual de normas", in CUÉLLAR, Leila e MOREIRA, Egon Bockmann, Estudos de Direito Econômico, Belo Horizonte: Fórum, 2004, páginas 161-206.

Agências Administrativas, Contratos de Serviços Públicos e Mutabilidade Regulatória. In Revista de Direito Público da Economia - RDPE, $\mathrm{n}^{\circ}$ 25. Belo Horizonte: Fórum, jan/mar 2009, páginas 101-117.

MOREIRA, Vital. A Ordem Jurídica do Capitalismo. $3^{\text {a }}$ ed. Coimbra: Centelho, 1987.

Auto-Regulação Profissional e Administração Pública. Coimbra: Almedina, 1997.

MOREIRA NETO, Diogo de Figueiredo. Direito Regulatório. Rio de Janeiro: Renovar, 2003.

. Curso de Direito Administrativo. $15^{\mathrm{a}}$ ed. Rio de Janeiro: Renovar,

2009.

Ordem Econômica e Desenvolvimento na Constituição de 1988. Rio de Janeiro: APEC, 1989.

Considerações sobre a Lei de Responsabilidade Fiscal. Rio de Janeiro: Renovar, 2001.

MORÓN, Miguel Sanchez. El principio de participación en la Constitución española. In Revista de Administración Pública, $\mathrm{n}^{\mathbf{o}}$ 89. Madrid: Centro de Estudios Políticos y Constitucionales, mai/ago 1979, páginas 171-206.

NESTER, Alexandre Wagner. Regulação e Planejamento: A Criação do PRO-REG. In MOREIRA, Egon Bockmann e MATTOS, Paulo Todescan Lessa (coords.), Direito Concorrencial e Regulação Econômica. Belo Horizonte: Fórum, 2010, páginas 467-480. 
NEUNER, Jörg. Los Derechos Humanos Sociales. In Anuario Iberoamericano de Justicia Constitucional, $\mathrm{n}^{\circ}$ 15. Madrid: Centro de Estudios Políticos y Constitucionales, jan/dez 2011, páginas 239-265.

NUSDEO, Fábio. Curso de Economia. 6a ed., São Paulo: Revista dos Tribunais, 2010.

OECD, Organização para a Cooperação e Desenvolvimento Econômico. Regulatory Impact Analysis: A Tool For Policy Coherence, 2009.

Building an Institutional Framework for Regulatory Impact Analysis (RIA): Guidance for Policy Makers, version 1.1. Regulatory Policy Division - Directorate for Public Governance and Territorial Development, Paris, 2008.

Regulatory Impact Analysis (RIA) Inventory. Public Governance and Territorial Development Directorate, abr/2004. Disponível em: http://www.oecd.org/regreform/ regulatorypolicy/35258430.pdf.

OLIVEIRA, Fábio Corrêa Souza de. Morte e Vida da Constituição Dirigente. Rio de Janeiro: Lumen Juris, 2010.

OLIVEIRA, Rafael Carvalho Rezende de. Governança e Análise de Impacto Regulatório, in Revista de Direito Público da Economia - RDPE, $\mathrm{n}^{\circ} 36$, Belo Horizonte: Fórum, out/dez 2011, páginas 173-203.

ORTIZ, Gaspar Ariño. Principios de Derecho Público Económico. $3^{\text {a }}$ ed. Granada: Comares Editorial, 2004.

Estado y Economia. Buenos Aires: Abeledo-Perrot, 1993.

OTERO, Paulo. Legalidade e Administração Pública: O Sentido da Vinculação Administrativa à Legalidade. Coimbra: Almedina, 2003.

Vinculação e Liberdade de Conformação Jurídica do Sector Empresarial do Estado. Coimbra: Coimbra Editora, 1998.

PALASÍ, José Luis Villar. Poder de Policía y Precio Justo. El Problema de la Tasa de Mercado. In Revista de Administración Pública, $\mathrm{n}^{\circ}$ 16. Madrid: Centro de Estudios Políticos y Constitucionales, jan/abr 1955, páginas 11-83.

PARDO, José Esteve. Autorregulación: genesis y efectos. Navarra: Editorial Arazandi, 2002. 
PEDREIRA, Carlos Eduardo Bulhões. Monopólio - Gás. In Revista Trimestral de Direito Público - RTDP, $\mathrm{n}^{\circ}$ 10. São Paulo: Malheiros Editores, 1995, páginas 134-157.

PELKMANS, Jacques, LABORY, Sandrine e MAJONE Giandomenico. Better EU Regulatory Quality: Assessing Current Initiatives and New Proposals. In GALLI, Giampaolo e PELKMANS, Jacques (ed.), Regulatory Reform and Competitiveness in Europe: Horizontal Issues, Vol. I. Massachusetts: Edward Elgar Publishing, 2000, páginas 461-526.

PEREZ, Marcos Augusto. A Administração Pública Democrática. Belo Horizonte: Fórum, 2004.

PÉREZ-DÍAZ, Victor. The Voices of Civil Societies. ASP Reserarch Paper 83(b)/2008. Disponível em: http://www.asp-research.com/pdf/Asp\%2083b.pdf.

. Markets as Conversations: Markets' Contribution to Civility, the Public Sphere and Civil Society at Large, in PÉREZ-DÍAZ, Victor (ed.), Markets and Civil Society: The European Experience in Comparative Perspective, Nova Iorque: Berghahn Books, 2009, páginas 27-76.

PESSÔA VALENTE, Patrícia Rodrigues. A análise de impacto como mecanismo de controle do tabaco. In Revista de Direito público da Economia - RDPE, ano 8, $\mathrm{n}^{\circ}$ 32. Belo Horizonte: Fórum, out/dez 2010, páginas 109-135.

PNUD - Programa das Nações Unidas para o Desenvolvimento, Relatório do Desenvolvimento Humano de 2011. Disponível em: http://hdr.undp.org/en/media/HDR_2011_PT_Complete.pdf.

POGGI, Gianfranco. A Evolução do Estado Moderno. Rio de janeiro: Zahar Editores, 1981.

POLLITT, Christopher e TALBOT, Colin (orgs.). Unbundled Government: a critical analysis of the global trend to agencies, quangos and contractualization. Londres: Routledge, 2004.

POLANYI, Karl. La Gran Transformación: Critica del liberalismo económico. Madrid: La Piqueta, 2000.

PROSSER, Tony. The Regulatory Enterprise: Governement, Regulation and Legitimacy. Nova York: Oxford University Press, 2010.

QUADROS, Fausto. O Princípio da Subsidiariedade no Direito Comunitário após o Tratado da União Europeia. Coimbra: Almedina, 1995. 
RAGAZZO, Carlos Emmanuel Joppert. Regulação Jurídica, Racionalidade Econômica e Saneamento Básico. Rio de Janeiro: Renovar, 2011.

RAZ, Joseph. Razão Prática e Normas. Rio de Janeiro: Elsevier, 2010.

REICH, Norbert. A Crise Regulatória: ela existe e pode ser resolvida? - Análise comparativa sobre a situação da regulação social nos Estados Unidos e na Comunidade Econômica Européia. In MATTOS, Paulo Todescan Lessa et al (coords.), Regulação Econômica e Democracia - O Debate Europeu. São Paulo: Singular, 2006, páginas 17-52.

REIS, Jane. Interpretação Constitucional e Direitos Fundamentais. Rio de Janeiro: Renovar, 2006.

RIBEIRO, Ivan César. Regulatory Impact Analysis and Cost Benefit Analysis: What is different across the sea? In Revista de Direito Público da Economia - RDPE, n 32, Belo Horizonte: Fórum, out/dez 2010, páginas 73-87.

RODRÍGUES, Cândido Paz-Ares e ÁGUILA-REAL, Jesús Alfaro. Artículo 38. In BAHAMONDE, Maria Emilia Casas e BRAVO-FERRER, Miguel RodríguezPiñero y (orgs.), Comentarios a la Constitución Española. Madrid: Fundación Wolters Kluwer, 2008, páginas 980-1000.

RODRÍGUEZ DE SANTIAGO, José María. La Ponderación de Bienes e Intereses en el Derecho Administrativo. Madri: Marcial Pons, 2000.

Ponderación y Actividade Planificadora de la Administración, in ORTEGA, Luis e SIERRA, Susana de la (coords.), Ponderación y Derecho Administrativo, Madrid: Marcial Pons, 2009, páginas 115-133.

RÖPKE, Wilhelm. International Order And Economic Integration. Dordrecht: D. Reidel Publishing Company, 1959.

SALDANHA, Nelson. O Jardim e a Praça: ensaio sobre o lado "privado" e o lado "público" da vida social e história. In Ciência \& Trópico, $\mathrm{n}^{\circ} 11$. Recife: Massangana, jan/jul 1983, páginas 105-121.

SALGADO, Lucia Helena e BORGES, Eduardo Bizzo de Pinho. Análise de Impacto Regulatório: Uma Abordagem Exploratória, texto para discussão $n^{\circ} 1463$. Brasília: IPEA, 2010. Disponível em: http://www.regulacao.gov.br/publicacoes/ artigos/analise-de-impacto-regulatorio-uma-abordagem-exploratoria.

SALOMÃO FILHO, Calixto. Regulação e Desenvolvimento. In SALOMÃO FILHO, Calixto (coord.), Regulação e Desenvolvimento. São Paulo: Malheiros Editores, 2002, páginas 29-63. 
Regulação, Desenvolvimento e Meio Ambiente. In FILHO, Calixto Salomão (org.), Regulação e Desenvolvimento: novos temas. São Paulo: Malheiros Editores, 2012, páginas 15-59.

SÁNCHEZ AGESTA, Luis. El Principio de Función Subsidiaria. In Revista de Estudios Políticos, $\mathrm{n}^{\mathbf{0}}$ 121. Madrid: Centro de Estudios Políticos y Constitucionales, jan/fev 1962, páginas 5-19.

SANCHÍS, Luis Prieto. Ley, Princípios, Derechos. Madrid: Editorial Dykinson, 1998.

SANDULLI, Aldo M. Manuale di Diritto Amminitrativo. Napoli: Jovene, 1964.

SANTAMARÍA PASTOR, Juan Alfonso. Principios de Derecho Administrativo General, vol. II. Madrid: Iustel, 2009.

SANTOS, Luiz Alberto. Agencificação, Publicização, Contratualização e Controle Social: Possibilidades no âmbito da Reforma do Aparelho do Estado. Brasília: DIAP, 2000.

SARLET, Ingo Wolfgang e FIGUEIREDO, Mariana Filchtiner. Reserva do Possível, Mínimo Existências e Direito à Saúde: algumas aproximações. In SARLET, Ingo Wolfgang e TIMM, Luciano Benetti (orgs.), Direitos Fundamentais: orçamento e "reserva do possível". Porto Alegre: Livraria do Advogado, 2008, página 1153.

SARLET, Ingo Wolfgang e SCHOLLER, Heinrich. O princípio da proporcionalidade no direito constitucional e administrativo da Alemanha. In Interesse Público, $\mathrm{n}^{\circ}$ 2. Belo Horizonte: Fórum, abr/jun 1999, páginas 93-107.

SARMENTO, Daniel. Os Princípios Constitucionais e a Ponderação de Bens, in TORRES, Ricardo Lobo, Teoria dos Direitos Fundamentais, $2^{\mathrm{a}}$ ed. Rio de Janeiro: Renovar, páginas 35-98.

SCAGLIONE, Francesco. Il mercato e le regole della correttezza. Padova: Wolters Kluwer Italia, 2010.

SCHIRATO, Vitor Rhein. Livre Iniciativa nos Serviços Públicos. Belo Horizonte: Fórum, 2012.

SCHMITT, Cristiano Heineck. A Invocação dos Direitos Fundamentais no Âmbito das Pessoas Coletivas de Direito Privado. In Revista de Informação Legislativa, ano 37, nº 145. Brasília: Senado Federal, jan/mar 2000, páginas 55-70.

SEN, Amartya. Desenvolvimento como Liberdade. São Paulo: Companhia das Letras, 2007. 
SILVA, José Afonso da. Curso de Direito Constitucional Positivo. $33^{\mathrm{a}}$ ed. São Paulo: Malheiros Editores, 2010.

SILVA, Virgílio Afonso. Princípios e Regras: mitos e equívocos acerca de uma distinção. In Revista Latino-Americana de Estudos Constitucionais, v. 1. São Paulo: Del Rey, jan/jun 2003, páginas 607-630.

Direitos Fundamentais: conteúdo essencial, restrições e eficácia. São Paulo: Malheiros Editores, 2009.

O Proporcional e o Razoável. In Revista dos Tribunais, vol. 798. São Paulo: Revista dos Tribunais, abr/2002, páginas 23-50.

SOUSA FRANCO, António L. de. A Revisão da Constituição Económica. In Revista da Ordem dos Advogados, ano 42, Vol. III. Lisboa: Ordem dos Advogados, set/dez 1982, páginas 601-687.

Nota Sobre o Princípio da Liberdade Económica. In Boletim do Ministério da Justiça, no 355. Portugal: Ministério da Justiça, 1986, páginas 1140 .

SOUSA NETO, Cláudio Pereira de e MENDONÇA, José Vicente Santos de. Fundamentação e Fundamentalismo na Interpretação do Princípio Constitucional da Livre Iniciativa. In SOUZA NETO, Cláudio Pereira e SARMENTO, Daniel (orgs.), A Constitucionalização do Direito. Rio de Janeiro: Lumen Juris, 2007, páginas 709-741.

SOUSA NETO, Cláudio Pereira de. O Dilema Constitucional Contemporâneo entre o Neoconstitucionalismo Econômico e o Constitucionalismo Democrático. In SOUZA NETO, Cláudio Pereira de, Constitucionalismo Democrático e Governo das Razões. Rio de Janeiro: 2011, Lumen Juris, páginas 33-41.

SOUTO, Marcos Juruena Villela. Direito Administrativo Regulatório, $2^{\mathrm{a}}$ ed. Rio de Janeiro, Lumen Juris, 2005.

SUNDFELD, Carlos Ari. Direito Administrativo Ordenador. São Paulo: Malheiros Editores, 2003.

Editores, 2006.

. Fundamentos de Direito Público, $4^{a}$ ed. São Paulo: Malheiros

SUNDFELD, Carlos Ari e CÂMARA, Jacintho Arruda. Produtos perigosos: como a regulação equilibra interesses conflitantes? In Revista Brasileira de Direito Público - RBDP, n 34. Belo Horizonte: Fórum, jul/set 2011, páginas 73-90. 
SUNSTEIN, Cass R. After the Rights Revolution: Reconceiving the Regulatory State. Cambridge: Harvard University Press, 1990.

O Constitucionalismo Após o New Deal. In MATTOS, Paulo (coord.), Regulação Econômica e Democracia: O Debate Norte-Americano. São Paulo: Editora 34, 2004, páginas 131-242.

The Cost-Benefit State. University of Chicago Law School, John M. Olin Law \& Economics, Working Paper $\mathrm{n}^{\circ}$ 39, mai/1996. Disponível em: www.law.uchicago.edu/files/files /39.sunstein.pdf.

The Cost-Benefit State: The Future of the Regulatory State. Chicago: American Bar Association, 2002.

TÁCITO, Caio. A Reforma do Estado e a Modernidade Administrativa. In Temas de Direito Público (Estudos e Pareceres), $3^{\circ}$ vol. Rio de Janeiro: Renovar, 2002, páginas 41-50.

. O Retorno do Pêndulo: Serviço Público e Empresa Privada. O Exemplo Brasileiro. In Revista de Direito Administrativo - RDA, $\mathrm{n}^{\circ}$ 202. Rio de Janeiro: FGV, out/dez 1995, páginas 1-10.

TATSCH, Simone. Princípio da Subsidiariedade: deveres de abstenção e de atuação na atividade econômica. Tese (Doutorado em Direito Econômico) - FADUSP, 2005.

TAVARES, André Ramos. Curso de Direito Constitucional, $7^{\text {a }}$ ed. São Paulo: Saraiva, 2009.

Direito Constitucional Econômico, São Paulo: Método, 2003.

TAYLOR, Charles. Modern Social Imaginaries. Londres: Duke University Press, 2004.

TEPEDINO, Gustavo. Evolução da Responsabilidade Civil no Direito Brasileiro e suas Controvérsias na Atividade Estatal. In Temas de Direito Civil, $4^{\mathrm{a}}$ ed. Rio de Janeiro: Renovar, 2008, páginas 201-227.

THE EUROPEAN POLICY CENTER. Regulatory Impact Analysis: Improving the Quality of EU Regulatory Activity, ocasional paper, set/2001. Disponível em: http://ec.europa.eu/dgs/secretariat_general/admin_burden/docs/enterprise/ files/epc_paper_en.pdf.

TIMM, Luciano Benetti. O Direito Fundamental à Livre Inciativa. In O Novo Código Civil. Porto Alegre: Livraria do Advogado, 2008, páginas 97-112. 
TOLEDO, Gastão Alves de. O Direito Constitucional Econômico e sua Eficácia. Rio de Janeiro: Renovar, 2004.

TOSATO, Egidio. Persona, Società Intermedie e Stato. Milão: Giuffrè, 1989.

TORNOS MAS, Joaquín. La Ordenación Administrativa de los Precios Privados (Análisis del ordenamiento italiano). In Revista de Administración Pública, $\mathrm{n}^{\circ}$ 85. Madrid: Centro de Estudios Políticos y Constitucionales, mai/ago 1978, páginas 237-333.

TORRES, Ricardo Lobo. A Legitimação dos Direitos Humanos e os Princípios da Ponderação e da Razoabilidade. In TORRES, Ricardo Lobo, Legitimação dos Direitos Humanos, $2^{\text {a }}$ ed. Rio de Janeiro: Renovar, 2007, páginas 467-519.

TORRES, Silvia Faber. O Princípio da Subsidiariedade no Direito Público Contemporâneo. Rio de Janeiro: Renovar, 2001.

TRUBEK, David M. e SANTOS, Alvaro. Introduction: The Third moment in Law and Development Theory and the Emergence of a New Critical Practice. In TRUBEK, David M. e SANTOS, Alvaro (ed.), The New Law and Economic Development: A Critical Appraisal. New York: Cambridge University Press, 2006, páginas 118.

VAZ, Manuel Afonso. Direito Económico: A Ordem Económica Portuguesa, $4^{\mathrm{a}}$ ed. Coimbra: Coimbra Editora, 1998.

VENÂNCIO FILHO, Alberto. A Intervenção do Estado no Domínio Econômico: o direito público econômico no Brasil. Ed. fac-similar da de 1928. Rio de Janeiro: Renovar, 1998.

VERÍSSIMO, Marcos Paulo. Juízes Deferentes? In Revista Brasileira de Estudos Constitucionais, $n^{\circ}$ 22. Belo Horizonte: Fórum, abr/jun 2012, páginas 489-524.

Controle Judicial da Atividade Normativa das Agências de Regulação Brasileiras. In ARAGÃO, Alexandre Santos (coord.), O Poder Normativo das Agências Reguladoras. Rio de Janeiro: Forense, 2006, páginas 377-407.

VILHENA, Maria do Rosário. O Princípio da Subsidiariedade no Direito Comunitário. Coimbra: Almedina, 2002.

WEATHERILL, Stephen. The Challenge of Better Regulation. In WEATHERILL, Stephen (ed.), Better Regulation, Oxford: Hart Publishing, 2007, páginas 1-18.

WEISS, Linda. Is the state being 'transformed' by globalization? In WEISS, Linda (org.), States in the Global Economy: Bringing Domestic Institutions Back In. Cambridge: Cambridge University Press, 2003, páginas 293-317. 
WILLIAMSON, John. What Washington Means by Policy Reform. In WILLIAMSON, John (ed.), Latin American Adjustment: How Much Has Happened? Washington: Institute for International Economics, 1990, páginas 7-38.

ZAGREBELSKY, Gustavo. El derecho dúctil: Ley, derechos, justicia, $8^{\mathrm{a}}$ ed. Madrid: Editorial Trotta, 2008.

ZIPPELIUS, Reinhold. Teoria Geral do Estado. $3^{\text {a }}$ ed., Lisboa: Fundação Calouste Gulbenkian, 1997.

\section{NOTÍCIAS}

O ESTADO DE SÃO PAULO. Governo restringe instalação de portos privados. Economia \& Negócios, 18.01.2010. Disponível em: http://www.estadao.com.br/noticias/ economia, governo-restringe-instalacao-deportos-privados,497436,0.htm.

AGÊNCIA ESTADO. Clínicas retomam sessões de bronzeamento artificial, 14.01.2010. Disponível em: http://www.abril.com.br/noticias/comportamento /clinicas-retomam-bronzeamento-liberado-justica-526046.shtml.

ANVISA. Diretor da Anvisa aborda propaganda de alimentos em audiência do Senado, 09.12.2010. Disponível em: http://portal.anvisa.gov.br/wps/content/ anvisa+portal/anvisa/sala+de+imprensa/menu+-+noticias+anos/2010+noti cias/diretor $+d a+$ anvisa + aborda + propaganda + de + alimentos $+e m+$ audiencia $+d o$ tsenado. 